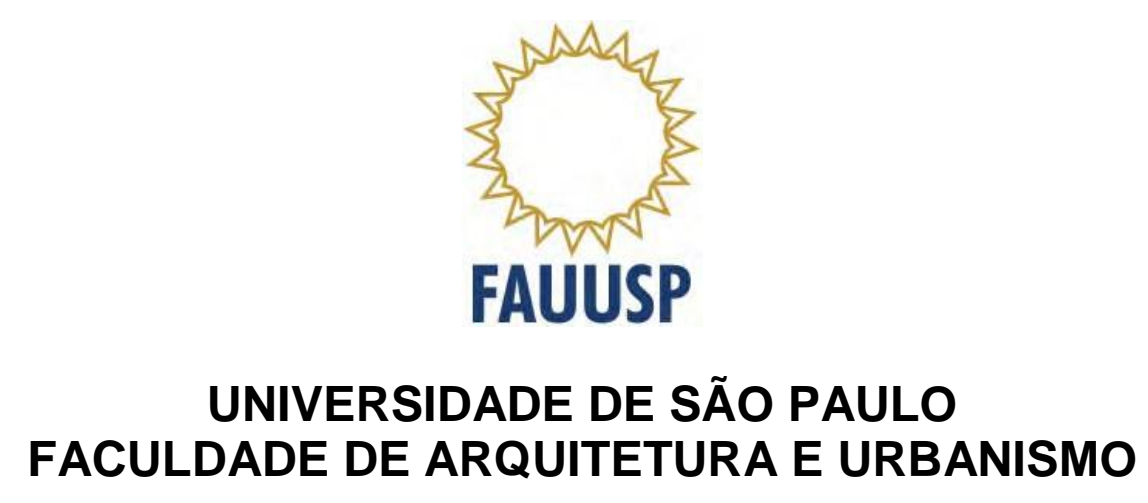

RAFAEL COSTA DE MOURA

Habitação social em Fortaleza-CE pós Ministério das Cidades: análise das intervenções promovidas pelo governo municipal 
RAFAEL COSTA DE MOURA

\section{Habitação social em Fortaleza-CE pós Ministério das Cidades: análise das intervenções promovidas pelo governo municipal}

Versão Original

Dissertação apresentada ao Programa de PósGraduação em Arquitetura e Urbanismo da Universidade de São Paulo para obtenção do título de título de Mestre em Ciências, Programa de Arquitetura e Urbanismo.

Área de Concentração: Habitat

Orientadora: Profa. Dra. Maria Camila Loffredo D'Ottaviano

São Paulo

2017 
AUTORIZO A REPRODUÇÃO E DIVULGAÇÃO TOTAL OU PARCIAL DESTE TRABALHO, POR QUALQUER MEIO CONVENCIONAL OU ELETRÔNICO, PARA FINS DE ESTUDO E PESQUISA, DESDE QUE CITADA A FONTE.

E-MAIL DO AUTOR: rafademoura@gmail.com

Moura, Rafael Costa de

M929h Habitação social em Fortaleza-CE pós Ministério das Cidades: análise das intervenções promovidas pelo governo municipal / Rafael Costa de Moura. -- São Paulo, 2017. 178 p. : il.

Dissertação (Mestrado - Área de Concentração: Habitat) - FAUUSP. Orientadora: Maria Camila Loffredo D'Ottaviano

1.Politica habitacional - Fortaleza (CE) 2. Habitação de interesse social 3.Análise de inserção urbana 4.Ministério das Cidades 5.Fundação de Desenvolvimento Habitacional de Fortaleza, (HABITAFOR) I.Título 
Nome: MOURA, Rafael Costa de

Título: Habitação social em Fortaleza pós Ministério das Cidades: análise das intervenções promovidas pelo governo municipal

Dissertação apresentada ao Programa de PósGraduação em Arquitetura e Urbanismo da Universidade de São Paulo para obtenção do título de título de Mestre em Ciências, Programa de Arquitetura e Urbanismo.

Aprovado em:

Banca Examinadora

Prof. Dr.

Julgamento:

Assinatura:

Prof. Dr.

Julgamento:

Assinatura:

Prof. Dr.

Julgamento:

Assinatura: 
A meu sobrinho Levi que veio nos mostrar o quanto é preciso amor e luta nesta nossa breve passagem. 


\section{AGRADECIMENTOS}

A minha esposa, Sara, com quem compartilho os pequenos prazeres cotidianos, as crises existenciais e as questões acadêmicas, cujo apoio e incentivo foi fundamental na realização deste trabalho.

A meus pais, Roberto e Helga, sem os quais seria impossível ter caminhado até este momento.

A minha irmã Sabrina e meu cunhado Mateus, com quem dividi morada no primeiro semestre em São Paulo, cujo apoio permitiu me manter no mesmo apartamento durante o segundo semestre, mesmo com seu retorno a Fortaleza.

A minha irmã Beatriz, pelo incentivo constante.

A minha avó, Vilani, pelo apoio incondicional, mesmo sem compreender do que se trata esta caminhada.

Aos amigos Odorico, Ciro e Vidal, que abriram suas portas para me receber nos momentos iniciais de vida em São Paulo.

À amiga Camila Aldigueri, companheira de morada e de angústias acadêmicas (e políticas), pelo material disponibilizado sobre o PLHISFor e o Programa Integrado de Desfavelamento, de grande importância para este trabalho.

Ao amigo Rérisson Máximo, pelas entrevistas cedidas, que muito contribuíram com esta pesquisa.

Aos entrevistados, André Almeida, André Carneiro, Daniel Rodrigues, Eduardo Aquino, Elias Paiva, Larissa Bisio, Olinda Marques, Solange Braga e Virgínia Hatsue, pela disponibilidade em compartilhar seus conhecimentos e experiências.

A todos os ex-colegas e amigos de HABITAFOR, com quem muito pude aprender nos anos de convivência e a quem recorro até hoje com dúvidas, em especial a Kelma Pinheiro, Sharon Dias, Fernanda Marques, Terezinha Bizerra, João Sérgio, Thaís Ponte, Nággila Frota, Nilton Alcântara, Virgínia Hatsue, Thêmis Aragão, Glaucia 
Hansen, Talita Miranda, Kamila Linhares, Filomeno Abreu, Izabel Tabosa e Thiago Martins.

Aos amigos e colegas de FAU-USP, Larissa Viana, Luíza Sassi, Márcia Prestes, Miguel Bustamante, Márcio, Karina e Lara, com os quais pude aprender e compartilhar as dificuldades de pesquisa e mestrado, especialmente à Carolina Domingues, pela ajuda com a entrega do relatório da bolsa.

Aos colegas de estágio à docência, Raquel Dantas, Letícia Lindenberg, Fábio Custódio e Guilherme Formicki, pelo companheirismo e aprendizado.

Aos amigos de "cativeiro da tese", Hulda Wehmann e Victor lacovini, pelo incentivo nos momentos de desânimo. Força, que estamos quase lá!

Aos professores da FAU-USP com quem tive oportunidade de estudar, em especial à Beatriz Rufino, Nabil Bonduki, Paula Santoro e Raquel Rolnik pelo aprendizado no estágio à docência.

Ao professor Paulo César, por mostrar caminhos até então para mim desconhecidos na análise da questão urbana e pela sinceridade nas críticas aos trabalhos.

À professora Lurdinha Zuquim, por abrir as portas do laboratório Napplac para auxiliar na realização do trabalho sobre a favela Jaguaré.

Ao professor Caio Santo Amore pelas contribuições durante o exame de qualificação.

Ao professor e amigo, Renato Pequeno, sempre disponível para ajudar, mesmo quando o tempo é escasso, na elaboração do projeto de pesquisa para seleção do mestrado, nas contribuições durante a banca de qualificação e no restante do desenvolvimento da pesquisa.

A minha orientadora professora Camila D'Ottaviano, pela paciência e atenção na orientação do desenvolvimento deste trabalho e pela confiança e amizade.

Aos amigos de Fortaleza, Pipoca, Lyvia, João, Tina, Isabel, Igor, Alinne, Jacques, Thaís, Fernando, Wilson, Roberta, Nyelsen, Sara e Alano, pelos momentos de descontração, "que também sem a cachaça ninguém segura esse rojão". 
Ao Conselho Nacional de Desenvolvimento Científico e Tecnológico (CNPq), pelo apoio financeiro a partir de 2015.

E a todos aqueles que contribuíram de alguma forma para que eu pudesse chegar até este momento e que, por um lapso de memória, eu tenha esquecido de mencionar. Meu mais sincero obrigado! 


\section{RESUMO}

MOURA, Rafael Costa de Moura. Habitação social em Fortaleza pós Ministério das Cidades: análise das intervenções promovidas pelo governo municipal. 2017. 178 f. Dissertação (Mestrado) - Faculdade de Arquitetura e Urbanismo, Universidade de São Paulo, São Paulo, 2017.

A criação do Ministério das Cidades, em 2003, veio preencher a lacuna deixada pela extinção do Banco Nacional de Habitação (BNH), em 1986, como órgão nacional encarregado de pensar políticas para as principais questões relacionadas às aglomerações urbanas: o desenvolvimento urbano, a habitação, o saneamento ambiental e o transporte e mobilidade urbanos, buscando incorporar os instrumentos trazidos pelo Estatuto da Cidade para o planejamento urbano. Para aderir ao novo Sistema Nacional de Habitação implantado pelo Ministério, Estados, Municípios e Distrito Federal precisavam cumprir determinadas obrigações a fim de acessar os recursos do Fundo Nacional de Habitação de Interesse Social. Também em 2003, foi criada a Fundação de Desenvolvimento Habitacional de Fortaleza (HABITAFOR), posteriormente transformada em secretaria municipal, que passou a conduzir as ações habitacionais no município, com a implantação de intervenções bastante distintas pela cidade, especialmente no que se refere ao tipo, porte de cada uma. Nesse contexto, a pesquisa aqui apresentada objetiva analisar o impacto da atuação do Ministério das Cidades na política municipal de habitação de interesse social em Fortaleza-CE, visando identificar o reflexo das diretrizes por ele estabelecidas nas intervenções promovidas pelo município. Para isso, resgatamos o processo histórico de constituição da HABITAFOR, partindo do período de redemocratização do Brasil, e recorremos a uma análise de inserção urbana para dois estudos de caso, a intervenção Maravilha e o conjunto habitacional Maria Tomásia.

Palavras-chave: Política habitacional - Fortaleza (CE), Habitação de interesse social, Análise de inserção urbana, Ministério das Cidades, Fundação de Desenvolvimento Habitacional de Fortaleza, (HABITAFOR). 


\begin{abstract}
MOURA, Rafael Costa de Moura. Social housing in Fortaleza post Ministry of Cities: analysis of the interventions promoted by the municipal government. 2017. 178 f. Dissertação (Mestrado) - Faculdade de Arquitetura e Urbanismo, Universidade de São Paulo, São Paulo, 2017.
\end{abstract}

The creation of the Ministry of Cities in 2003, filled the gap left by the extinction of the National Housing Bank in 1986 as the national institution responsible for planning policies about the main issues related to urban agglomerations: urban development, housing, environmental sanitation and transportation and urban mobility, seeking to incorporate the instruments brought by the City Statute for urban planning. To join the new National Housing System implemented by the Ministry, States, Municipalities and the Federal District needed to fulfill certain obligations in order to access the resources of the National Social Housing Fund. Also in 2003, was created the Foundation for the Housing Development of Fortaleza (HABITAFOR), later transformed into a municipal secretary, which began to conduct housing actions in the municipality, implementing quite distinct interventions through out the city. In this context, this research aims to analyze the impact of the Ministry of Cities in the municipal policy of social housing in Fortaleza-CE, pursuing to identify the reflex of the guidelines established by it over the interventions promoted by the municipality. Therefore, we rescued the HABITAFOR's historic process of constitution, beggining from the period of Brazil's redemocratization, and peformed an analysis of urban insertion for two case studies, the Maravilha's intervention and the housing complex Maria Tomasia.

Keywords: Housing policy - Fortaleza (CE), Social housing, Analysis of urban insertion, Ministry of Cities, Fortaleza's Social Housing Foundation (HABITAFOR). 


\section{LISTA DE MAPAS}

Mapa 1 - Localização dos primeiros campos de concentração de retirantes em

Fortaleza .26

Mapa 2 - Primeiro mapeamento de favelas de Fortaleza .27

Mapa 3 - Favelas no espaço urbano de Fortaleza em 1973...................................38

Mapa 4 - Favelas propostas à erradicação em 1973.............................................39

Mapa 5 - Áreas propostas para nucleamentos habitacionais de desfavelados ........39

Mapa 6 - Mutirões implantados pela Prefeitura de Fortaleza entre 1986 e 2004 .....44

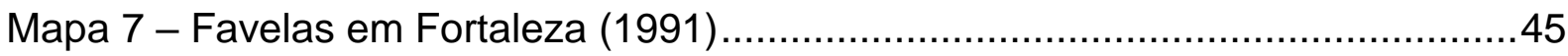

Mapa 8 - Conjunto São Cristóvão, Lotes Remanescentes e Campo Estrela ............47

Mapa 9 - Produção do Pró-Moradia pela PMF ..................................................51

Mapa 10 - Mapa das áreas de risco apresentado pelo PEMAS ……......................54

Mapa 11 - Levantamento das Áreas de Risco pelo CDPDH ..................................62

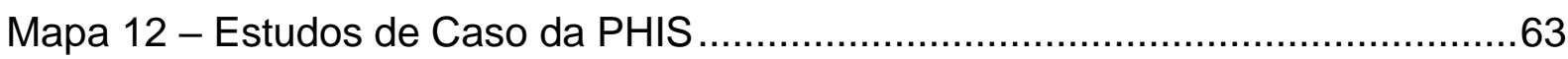

Mapa 13 - Intervenções do PHBB pela Prefeitura ................................................64

Mapa 14 - Assentamentos precários em Fortaleza (2012) …………................... 86

Mapa 15 - Intervenções trabalhadas pela HABITAFOR entre 2003 e 2012 ..............87

Mapa 16 - Projetos da HABITAFOR transformados em MCMV ..............................90

Mapa 17 - Intervenções realizadas pela HABITAFOR X PDDU-1992 _.....................104

Mapa 18 - Intervenções realizadas pela HABITAFOR X PDP-2009......................106

Mapa 19 - Novas ocupações associadas às intervenções da HABITAFOR ............116

Mapa 20 - Localização das áreas de Origem e de Reassentamento de intervenções

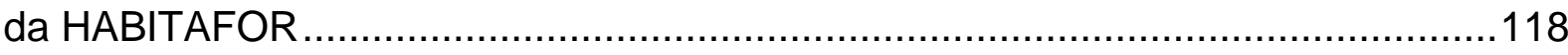

Mapa 21 - Favela Maravilha em 2003 ..........................................................127

Mapa 22 - Setores da intervenção Maravilha ..................................................129

Mapa 23 - Distância entre reassentamentos e áreas de origem ...........................136

Mapa 24 - Tempo de deslocamento e distância em relação a centralidades ..........138

Mapa 25 - Centralidades na Região Metropolitana de Fortaleza...........................139

Mapa 26 - Opções de Transporte para o conjunto Maria Tomásia.........................141

Mapa 27 - Opções de Transporte para os setores I a VI da intervenção Maravilha 
Mapa 28 - Setores censitários e área de entorno de $1 \mathrm{~km}$ a partir do perímetro na Maravilha

Mapa 29 - Setores censitários e área de entorno de $1 \mathrm{~km}$ a partir do perímetro no Maria Tomásia. 144

Mapa 30 - Análise do abastecimento de água na Maravilha e no Maria Tomásia e entorno 145

Mapa 31 - Análise do esgotamento sanitário na Maravilha e entorno. 146

Mapa 32 - Análise do esgotamento sanitário no Maria Tomásia e entorno 147

Mapa 33 - Análise do destino do lixo na Maravilha e entorno 148

Mapa 34 - Análise do destino do lixo no Maria Tomásia e entorno 149 Mapa 35 - Análise do serviço de energia elétrica na Maravilha e no Maria Tomásia 150

Mapa 36 - Usos cotidianos ou de abrangência local na Maravilha 152

Mapa 37 - Usos cotidianos ou de abrangência local no Maria Tomásia. 152

Mapa 38 - Usos eventuais ou de abrangência do bairro na Maravilha. 154

Mapa 39 - Usos eventuais ou de abrangência do bairro no Maria Tomásia .154

Mapa 40 - Usos esporádicos ou de abrangência da cidade na Maravilha 156

Mapa 41 - Usos esporádicos ou de abrangência da cidade no Maria Tomásia 156

\section{LISTA DE GRÁFICOS}

Gráfico 1 - Atribuições dos órgãos municipais na área de habitação .59 


\section{LISTA DE FIGURAS}

Figura 1 - Construções irregulares nas intervenções Maravilha (esq.) e Açude João Lopes (dir.) 99

Figura 2 - Ocupação dos equipamentos comunitários destinados ao conjunto Rosa Luxemburgo 111

Figura 3 - Piso intertravado e piso tátil utilizados na intervenção Açude João Lopes 119

Figura 4 - Conjunto Anita Garibaldi, antes da entrega às famílias (2006) 120

Figura 5 - Rampas de acesso nas calçadas do conjunto Casa e Renda 122

Figura 6 - Comunidade Maravilha e o Riacho Tauape antes da intervenção 128

Figura 7 - Maravilha Setor I (esq.) e Setor II (dir.) 130

Figura 8 - Equipamentos esportivos no Setor IV e Setor III ao fundo 130

Figura 9 - Ocupações na Lagoa da Zeza 131

Figura 10 - Ocupações na Vila Cazumba 132

Figura 11 - Situação das lagoas em 2006 em relação às áreas de preservação permanente .132

Figura 12 - Foto aérea do conjunto Maria Tomásia e entorno (2008) 133

Figura 13 - Projeto original do conjunto Maria Tomásia e as novas ocupações 134 


\section{LISTA DE QUADROS}

Quadro 1 - Mutirão Habitacional: (1) casas previstas e (2) concluídas em Fortaleza entre 1987 e 1989. 40

Quadro 2 - Produção do Pró-Moradia pela PMF 49

Quadro 3 - Hierarquização das Áreas de Risco do PEMAS .54

Quadro 4 - Componentes da Matriz do PEMAS de Fortaleza 59

Quadro 5 - Recursos humanos da COMHAB. .64

Quadro 6 - Programas habitacionais trabalhados pelo MCidades. 69

Quadro 7 - Intervenções habitacionais da HABITAFOR entre 2003 e 2012 .80

Quadro 8 - Síntese das diretrizes programáticas concebidas pelo MCidades. 101

Quadro 9 - Classificação para a variável Localização 136

Quadro 10 - Classificação do indicador Opções de Transporte 139

Quadro 11 - Análise das opções de transporte levantadas 141

Quadro 12 - Classificação do indicador Frequência do Transporte. 142

Quadro 13 - Resultados para o indicador Frequência do Transporte 142

Quadro 14 - Classificação para o indicador "Usos cotidianos ou de abrangência local" 150

Quadro 15 - Classificação para o indicador "Usos Eventuais ou de Abrangência do Bairro" 152

Quadro 16 - Classificação para o indicador "Usos Esporádicos ou de Abrangência da Cidade".

Quadro 17 - Classificação do indicador Relação com o Entorno. 156

Quadro 18 - Classificação para o indicador Tamanho das Quadras 158 


\section{LISTA DE TABELAS}

Tabela 1 - Classificação das intervenções da HABITAFOR conforme o Tipo ...........95

Tabela 2 - Classificação das Intervenções da HABITAFOR conforme o Porte ........97

Tabela 3 - Classificação das Intervenções da HABITAFOR conforme a Tipologia

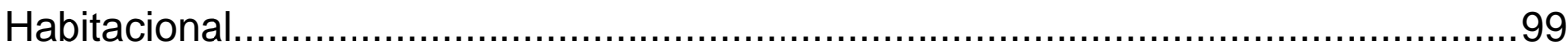

Tabela 4 - Situação das obras da HABITAFOR iniciadas entre 2005 e 2012, em

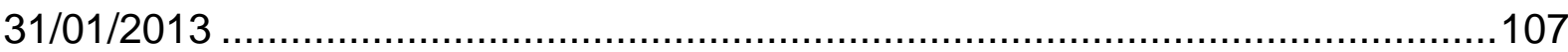

Tabela 5 - Evolução orçamentária da HABITAFOR entre 2012 e 2016 .................108 Tabela 6 - Evolução do quantitativo de funcionários da HABITAFOR entre 2012 e 2016 108

Tabela 7 - Resultado da análise do indicador Localização em relação a centralidades 136

Tabela 8 - Resultado da variável Opções de Transporte, do indicador Mobilidade 139

Tabela 9 - Resultado da análise dos itinerários 141

Tabela 10 - Resultado da análise para o indicador "Relação com o Entorno" 157

Tabela 11 - Resultado da análise para o indicador "Tamanho das Quadras" 158 


\section{LISTA DE SIGLAS E ABREVIAÇÕES}

ABNT - Associação Brasileira de Normas Técnicas

ANOREG - Associação dos Notários e Registradores do Brasil

AOP - Análise de Orientação Prévia

APO - Avaliação Pós-Ocupação

APP - Área de Preservação Permanente

ARENA - Aliança Renovadora Nacional

BID - Banco Interamericano de Desenvolvimento

BNH - Banco Nacional de Habitação

CAGECE - Companhia de Água e Esgoto do Ceará

CAIXA - Caixa Econômica Federal

CDPDH - Centro de Defesa e Promoção dos Direitos Humanos da Arquidiocese de Fortaleza

CETREDE - Centro de Treinamento e Desenvolvimento

CGFNHIS - Conselho Gestor do Fundo Nacional de Habitação de Interesse Social

CNDU - Comissão Normativa de Desenvolvimento Urbano

COELCE - Companhia Energética do Ceará

COHAB - Companhia de Habitação

COHAB-CE - Companhia de Habitação do Estado do Ceará

COMHAB - Comissão de Implantação de Projetos Habitacionais de Interesse Social e Infraestrutura Urbana

COMHAP - Conselho Municipal de Habitação Popular

CONCIDADES - Conselho das Cidades

CP - Cearah Periferia (Centro de Estudos, Articulação e Referência sobre

Assentamentos Humanos)

$\mathrm{CPH}$ - Coordenação de Programas Habitacionais

CPPD - Comissão Permanente de Avaliação do Plano Diretor

DCE - Diretório Central dos Estudantes

DI - Desenvolvimento Institucional

DS - Democracia Socialista 
ETUFOR - Empresa de Transporte Urbano de Fortaleza

FAS - Fundação de Ação Social

FAUUSP - Faculdade de Arquitetura e Urbanismo da Universidade de São Paulo

FBFF - Federação de Bairros e Favelas de Fortaleza

FGTS - Fundo de Garantia do Tempo de Serviço

FICAM - Programa de Financiamento para Construção, Ampliação e Melhoria

FMDS - Fundo Municipal de Desenvolvimento Social

FMDU - Fundo Municipal de Desenvolvimento Urbano

FMH - Fundo Municipal de Habitação

FNHIS - Fundo Nacional de Habitação de Interesse Social

FUNSESCE - Fundação dos Serviços Sociais do Estado do Ceará

FSSF - Fundação do Serviço Social de Fortaleza

GEC - Governo do Estado do Ceará

GT - Grupo de Trabalho

HABITAFOR - Fundação de Desenvolvimento Habitacional de Fortaleza (até 2013) /

Secretaria do Desenvolvimento Habitacional de Fortaleza (a partir 2013)

HIS - Habitação de Interesse Social

IBGE - Instituto Brasileiro de Geografia e Estatística

IPLAM - Instituto de Planejamento do Município

IPLANFOR - Instituto de Planejamento de Fortaleza

ITDP - Instituto de Políticas de Transporte e Desenvolvimento

LabCidade - Laboratório Espaço Público e Direito à Cidade

LEHAB - Laboratório de Estudos da Habitação

LUOS - Lei de Uso e Ocupação do Solo

MBES - Ministério da Habitação e do Bem-Estar Social

MCIDADES - Ministério das Cidades

MDU - Ministério do Desenvolvimento Urbano e Meio Ambiente

MHU - Ministério da Habitação, Urbanismo e Meio Ambiente

NBR - Norma Brasileira

NUHAB - Núcleo de Habitação e Meio Ambiente

OGU - Orçamento Geral da União 
OP - Orçamento Participativo

PAC - Programa de Aceleração do Crescimento

PAIH - Plano de Ação Imediata para a Habitação

PAR - Programa de Arrendamento Residencial

PC do B - Partido Comunista do Brasil

PDDU - Plano Diretor de Desenvolvimento Urbano

PDP - Plano Diretor Participativo

PDS - Partido Democrático Social

PEMAS - Plano Estratégico Municipal de Assentamentos Subnormais

PGM - Procuradoria Geral do Município

PHB - Programa Habitar Brasil

PHBB - Programa Habitar Brasil/BID

PHIS - Política Habitacional de Interesse Social

PLANASA - Plano Nacional de Saneamento Básico

PLANDIRF - Plano de Desenvolvimento Integrado da Região Metropolitana de Fortaleza

PlanHab - Plano Nacional de Habitação

PLANHAP - Plano Nacional de Habitação Popular

PLHISFor - Plano Local de Habitação de Interesse Social de Fortaleza

PMCMV - Programa Minha Casa Minha Vida

PMDB - Partido do Movimento Democrático Brasileiro

PMF - Prefeitura Municipal de Fortaleza

PND - Plano Nacional de Desenvolvimento

PNDU - Política Nacional de Desenvolvimento Urbano

PNH - Política Nacional de Habitação

PP - Partido Progressista

PPA - Plano Plurianual

PROAFA - Fundação Programa de Assistência às Favelas da Zona Metropolitana de Fortaleza

PROFILURB - Programa de Financiamento de Lotes Urbanizados

PROMORAR - Programa de Erradicação da Sub-habitação 
PSB - Partido Socialista Brasileiro

PSDB - Partido da Social Democracia Brasileira

PSH - Programa de Subsídio Habitacional

PT - Partido dos Trabalhadores

PTTS - Plano de Trabalho Técnico Social

RMF - Região Metropolitana de Fortaleza

SAG - Secretaria de Ação Governamental

SBPE - Sistema Brasileiro de Poupança e Empréstimo

$\mathrm{SCH}$ - Sociedades Comunitárias Habitacionais

SDU - Secretaria de Desenvolvimento Urbano

SEAC - Secretaria Especial de Habitação e Ação Comunitária

SEDU/PR - Secretaria Especial de Desenvolvimento Urbano da Presidência da República

SEINF - Secretaria Municipal de Desenvolvimento Urbano e Infraestrutura

SEPOG - Secretaria Municipal do Planejamento, Orçamento e Gestão

SEPUR - Secretária de Política Urbana

SER - Secretarias Executivas Regionais

SERFHAU - Serviço Federal de Habitação e Urbanismo

SFH - Sistema Financeiro da Habitação

SHM - Subsistema de Habitação de Mercado

SIG - Sistemas de Informação Geográfica

SMDE - Secretaria Municipal de Desenvolvimento Econômico

SMDS - Secretaria Municipal de Desenvolvimento Social

SMDT - Secretaria Municipal de Desenvolvimento Territorial

SNH - Sistema Nacional de Habitação

SNHIS - Subsistema Nacional de Habitação de Interesse Social

SPLAM - Secretaria do Planejamento Urbano e Meio Ambiente

SPU - Secretaria de Patrimônio da União

STAS - Secretaria de Trabalho e Ação Social

TR - Termo de Referência

UAS - Urbanização de Assentamentos Subnormais 
UE - Unidade Executora

UEM - Unidade Executora Municipal

UFC - Universidade Federal do Ceará

UH - Unidades Habitacionais

UNE - União Nacional dos Estudantes

ZEIS - Zona Especial de Interesse Social

ZRE - Zona Residencial Especial 


\section{SUMÁRIO}

AGRADECIMENTOS

RESUMO

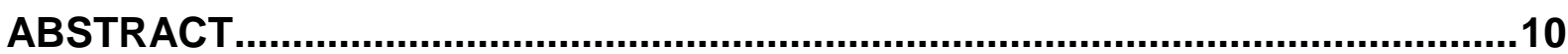

LISTA DE MAPAS

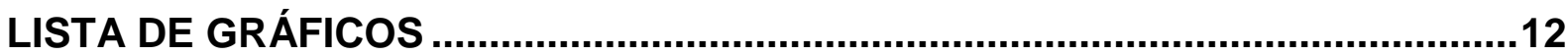

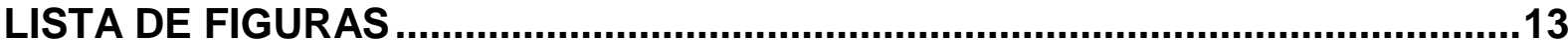

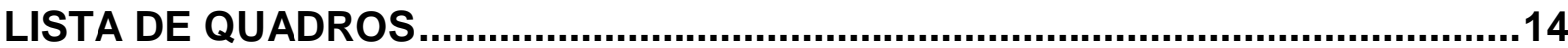

LISTA DE TABELAS

LISTA DE SIGLAS E ABREVIAÇÕES ............................................................16

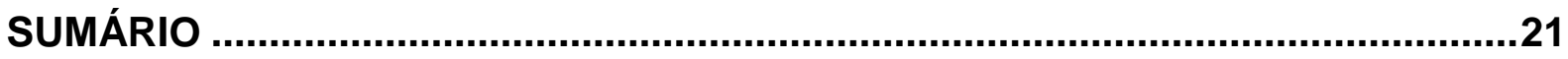

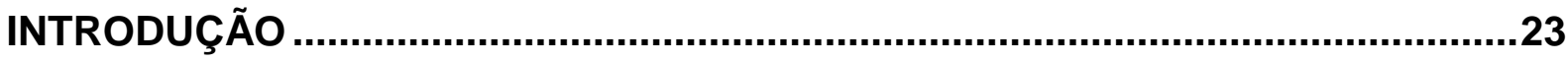

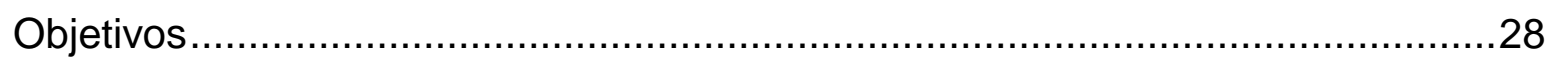

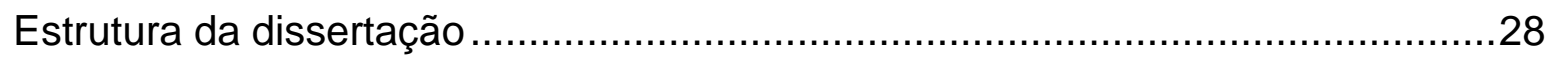

CAPÍTULO 01 - RESGATE HISTÓRICO …..........................................................30

1.1 A atuação da Comissão de Implantação de Projetos Habitacionais de Interesse Social e Infraestrutura Urbana (COMHAB) ....................................................

1.2 A criação da Fundação do Desenvolvimento Habitacional de Fortaleza (HABITAFOR) e a ampliação da oferta dos recursos federais ..............................45

1.2.1 A HABITAFOR na gestão Juraci Magalhães $(2003$ - 2004) .....................51

1.2.2 A HABITAFOR na gestão Luizianne Lins $(2005$ - 2012) ............................65

1.3 A criação da Secretaria Municipal do Desenvolvimento Habitacional de

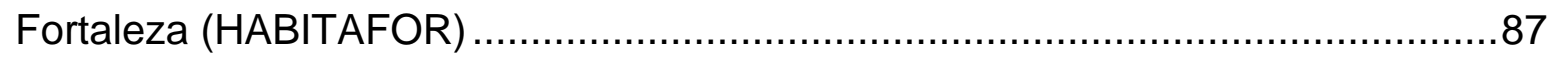

CAPÍTULO 02 - A PRODUÇÃO DE HABITAÇÃO DE INTERESSE SOCIAL PELO MUNICÍPIO DE FORTALEZA E AS DIRETRIZES DO MINISTÉRIO DAS CIDADES 
2.1.1. Tipo da Intervenção...........................................................................93

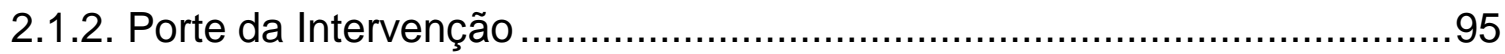

2.1.3. Quanto à Tipologia Habitacional .........................................................

2.2. Análise das Intervenções à luz das Diretrizes do Ministério das Cidades ....100

2.2.1 Diretrizes relacionadas à Política Urbana ...............................................101

2.2 Diretrizes relacionadas à Intervenção e seu Entorno ....................................113

2.3 Diretrizes relacionadas às Unidades Habitacionais ...................................118

2.4 Diretrizes relacionadas à Definição dos Beneficiários ..................................121

CAPÍTULO 03 - ANÁLISE DE INSERÇÃO URBANA …......................................124

3.1. A intervenção na Maravilha ..............................................................126

3.2 O conjunto Maria Tomásia ...................................................................129

3.2 Análise de Inserção Urbana..............................................................133

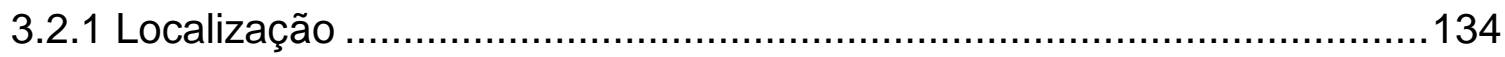

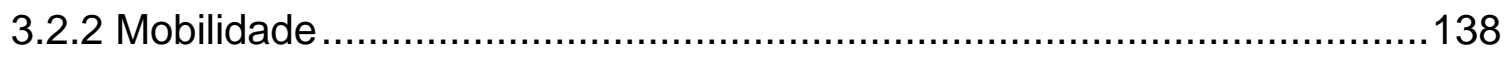

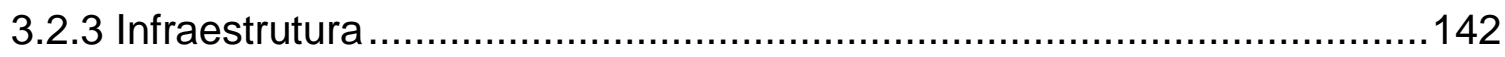

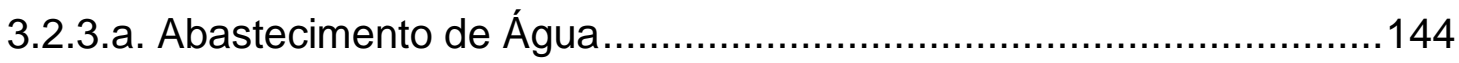

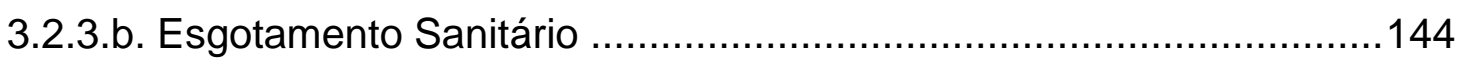

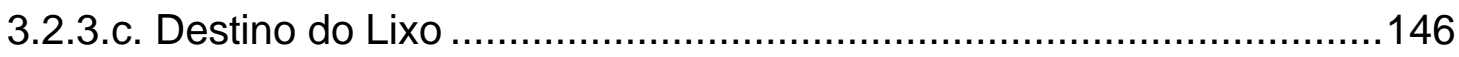

3.2.3.d. Energia Elétrica ................................................................. 148

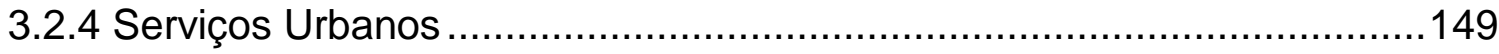

3.2.4.a. Usos cotidianos ou de abrangência local .....................................150

3.2.4.b. Usos Eventuais ou de Abrangência do Bairro .................................152

3.2.4.c. Usos Esporádicos ou de Abrangência da Cidade ...........................154

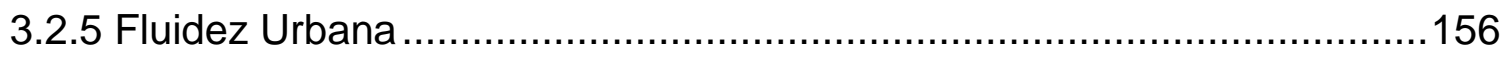

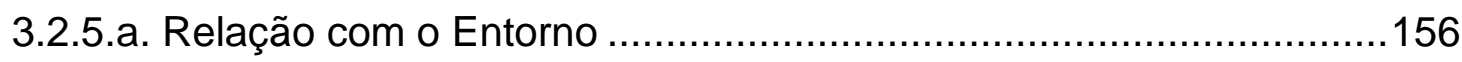

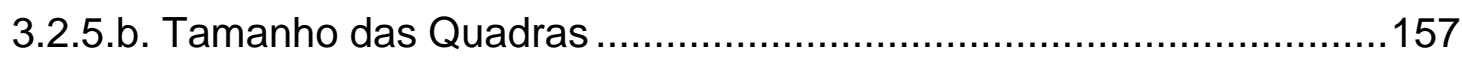


3.2.6. Uma síntese da análise de inserção urbana 158

CONSIDERAÇÕES FINAIS. 160 REFERÊNCIAS BIBLIOGRÁFICAS 
Habitação social em Fortaleza-CE pós Ministério das Cidades / Introdução - Página | 24

\section{INTRODUÇÃO}


O problema habitacional em Fortaleza remonta ao final do século XIX. Pequeno (2002), em referência à "Planta de Fortaleza em 1887", de Liberal de Castro (1979), registra que mais de $30 \%$ das moradias da cidade eram precárias, construídas em palha e ocupavam áreas de dunas e beiras de praia. O Arraial Moura Brasil, situado à beira mar, a oeste do centro histórico de Fortaleza, é mencionado como a primeira área de ocupação, o primeiro assentamento precário (PEQUENO, 2002, p. 75).

Em razão das sucessivas crises da agricultura cearense, da
concentração fundiária e das grandes secas, associadas à
inexistência de políticas públicas que assegurassem a sobrevivência
e a fixação das populações rurais quando da ocorrência de momentos
de maior instabilidade econômica ou climática, aconteceram intensos
deslocamentos rurais urbanos (ACCIOLY, 2009, p. 133). Para se ter uma ideia, na época da seca de 1877, no período de um ano, mais de 100 mil retirantes chegaram a Fortaleza, uma cidade que não contava com mais do que 27 mil habitantes (NEVES, 2000). Temendo revoltas, doenças ou outros tipos de transtornos com a chegada do grande contingente de retirantes, governo e elites procuraram direcioná-los para áreas distantes do centro urbano, em geral próximas das estações de trem ou perto de obras públicas (ALMEIDA, 2013), alocando-os em alojamentos que ficaram conhecidos como campos de concentração ${ }^{1}$, ou "Currais do Governo".

Segundo Almeida (2013), os maiores campos e o maior número deles se encontravam no interior do estado do Ceará. Sua localização em áreas próximas às estações ferroviárias buscava reter os retirantes antes mesmo que pudesse chegar à capital. Em Fortaleza, "os primeiros campos de alojamento ficavam no Prado (atualmente Benfica) e no Alagadiço (atualmente São Gerardo). As mulheres e famílias dos homens casados ficavam em um alojamento no Porangabussu (hoje imediações do Hospital das Clínicas)" (ARAGÃO, 2010, p. 58) (Mapa 1).

\footnotetext{
1 "É importante esclarecer o uso do termo campos de concentração. Na verdade, existia uma enorme diferença entre os campos de concentração do Ceará, e a experiência histórica do Nazismo na Segunda Guerra Mundial. Os campos no Ceará serviam para manter o controle da população que queria emigrar para Fortaleza nos períodos de seca. A população que ficava nos campos [...] geralmente executava os trabalhos da Inspetoria de Obras contra a seca, na construção de açudes, estradas de rodagem, poços, e, no caso de Fortaleza, melhorias urbanas" (ALMEIDA, 2013, p. 11). O que não retira o aspecto horrendo de tais lugares, pois a concentração de pessoas num ambiente pouco higiênico favorecia a proliferação de doenças, tornando-os locais para onde os retirantes iam apenas para morrer (NEVES, 2000).
} 
Mapa 1 - Localização dos primeiros campos de concentração de retirantes em Fortaleza

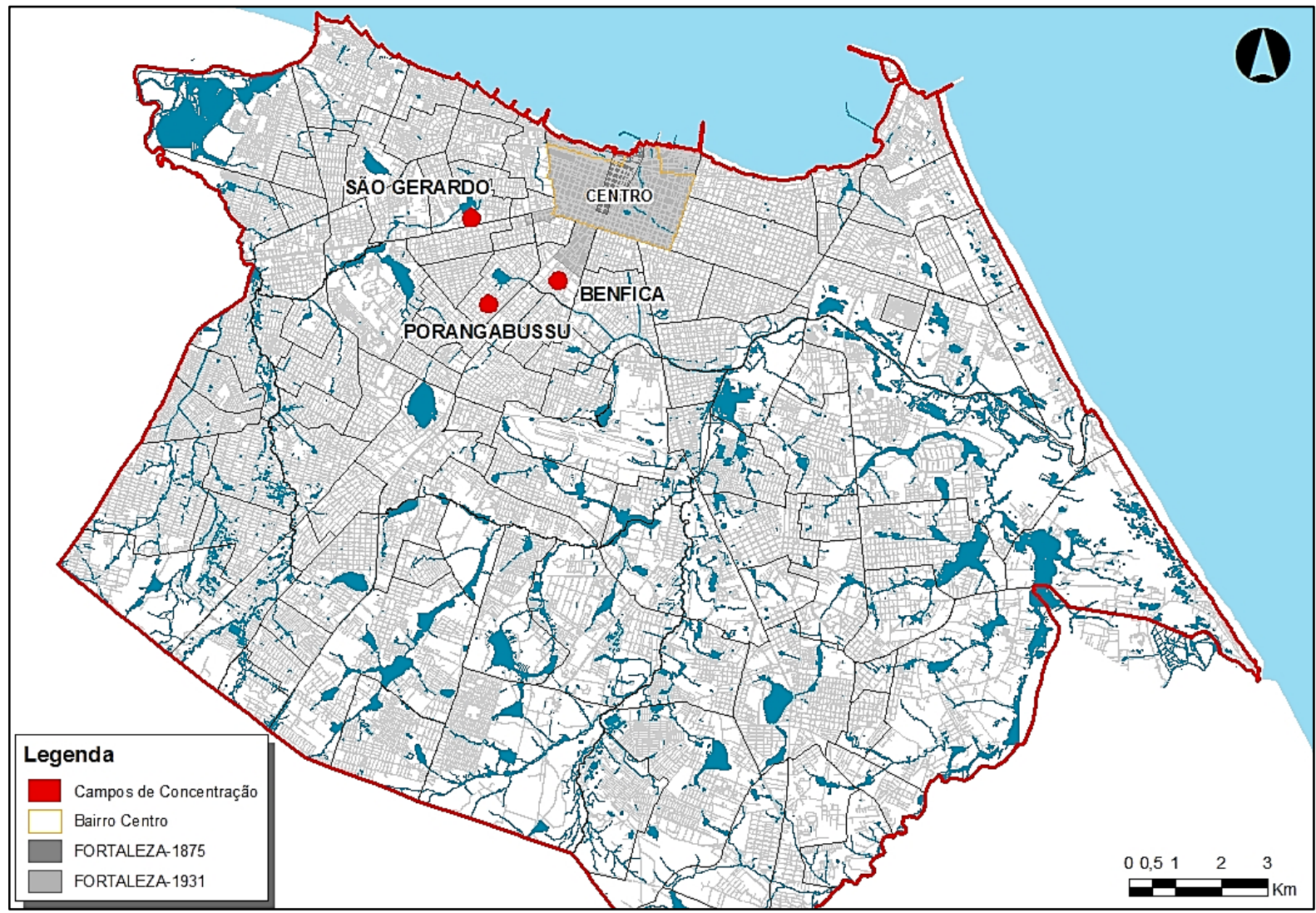

Fonte: Monteiro (2007) e Aragão (2010), adaptado pelo autor

Esse contingente de retirantes forneceu a mão-de-obra barata necessária para a execução das obras de modernização e embelezamento realizadas em Fortaleza no início do século XX. Para Almeida (2013), a utilização dos retirantes nessas obras, especialmente na seca de 1932, foi parte da estratégia adotada pelo Estado e pelas elites para exercer um certo controle social sobre a população que chegava em massa à capital cearense. Ao mesmo tempo, a chegada dos migrantes serviu de justificativa para o governo local obter recursos, junto ao governo federal, a fim de amenizar a situação de seca. "Quanto maiores as verbas e os organismos de atendimento, mais possibilidades de desvios, favorecimentos, uso político, etc." (NEVES, 2000, p. 92).

À população pobre que chegava a Fortaleza, fugida da seca no sertão, restou estabelecer-se em áreas impróprias, como encostas, morros, dunas, margens de lagoas e rios. Inicialmente em áreas próximas aos locais de emprego, como na área industrial que se estabelecia na zona oeste da cidade, e posteriormente em áreas cada vez mais distantes, ou mesmo fora do perímetro urbano, através um processo deliberado de expulsão dos casebres "justificado" pelas obras viárias e de aformoseamento do centro. 
Em meados da década de 1950, "Calculava-se em 100.000 o número de pessoas que moravam em mocambos, mais ou menos um quarto da população da cidade" (JUCÁ, 2003, p. 54). Apesar de ser um problema antigo, apenas nos anos 1960 foi realizado um primeiro mapeamento de favelas em Fortaleza (Mapa 2).

Mapa 2 - Primeiro mapeamento de favelas de Fortaleza

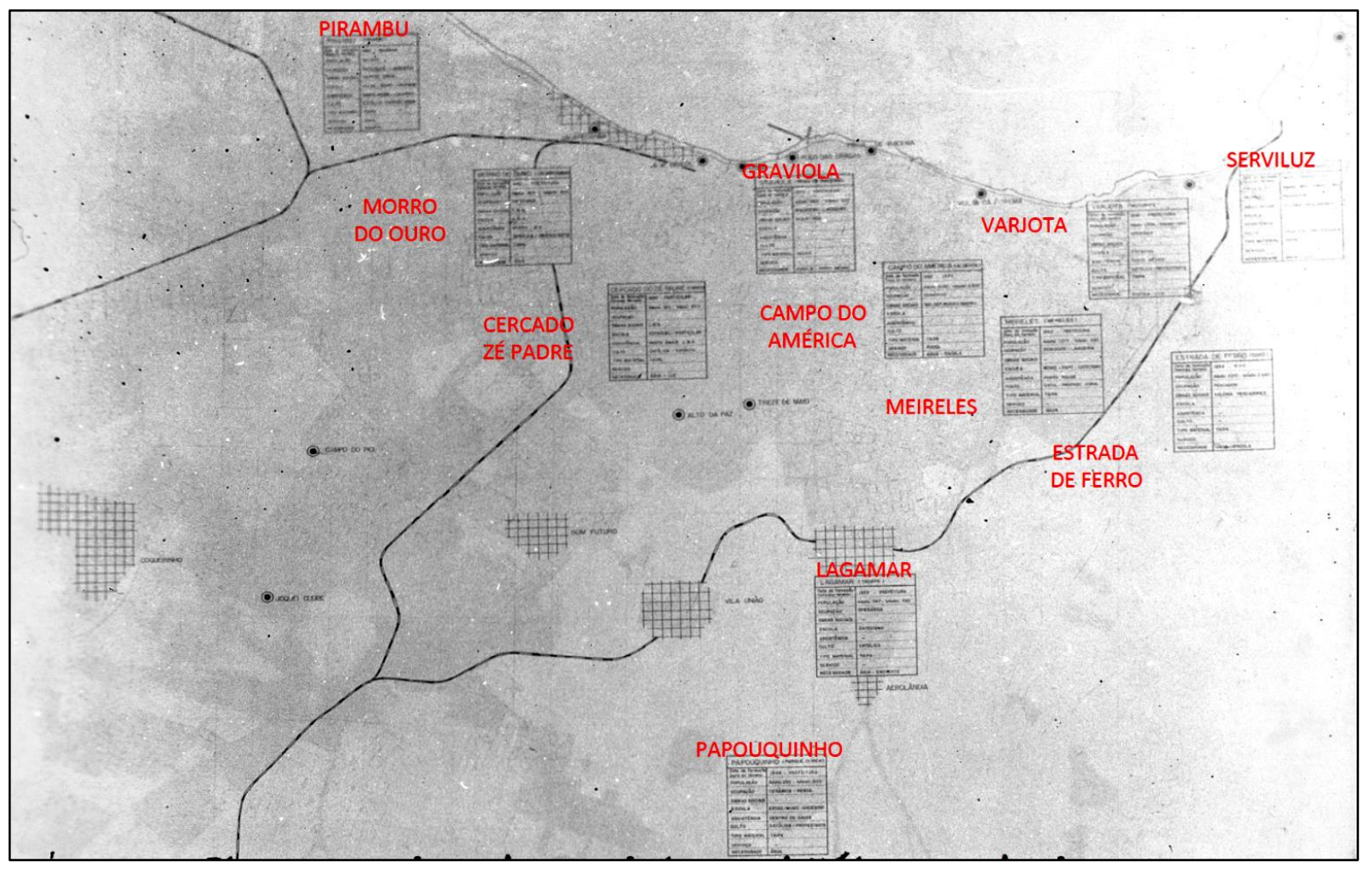

Fonte: Plano Diretor Hélio Modesto em 1963, acervo LEHAB (UFC)

Nos anos 1970, o Plano Integrado de Desfavelamento já apontava a existência de uma população moradora de favelas da ordem de 205.506 habitantes, cerca de $20,59 \%$ da população de Fortaleza (FORTALEZA, 1973). A principal solução adotada para enfrentar o problema foi a construção de grandes conjuntos isolados na periferia da cidade pela Companhia de Habitação do Ceará (COHAB-CE), com financiamentos do Banco Nacional de Habitação (BNH).

Os anos 1980 viram o fim do regime militar e a extinção do $\mathrm{BNH}$, em 1986. A política habitacional passou por um período de ações desarticuladas, em que os municípios foram compelidos a assumir a condução das políticas habitacionais, num processo de descentralização perversa (CARDOSO, 2001). O Cadastro de Favelas de Fortaleza, elaborado pelo governo estadual, em 1991, apontava a existência de 314 assentamentos favelados, nos quais viviam mais de 108 mil famílias (PEQUENO, 
2008). Em meio ao cenário brevemente descrito, nos anos 1990, há uma redução na atuação pelo estado, que extingue a COHAB em 1999, passando o município a assumir o enfrentamento da questão.

Com a criação do Ministério das Cidades no governo Lula, em 2003, o governo federal retoma o protagonismo na coordenação, gestão e formulação das políticas urbanas. Em Fortaleza, é criada a Fundação de Desenvolvimento Habitacional de Fortaleza (HABITAFOR), como decorrência do programa Habitar Brasil-BID, iniciado ainda no governo Fernando Henrique. Durante a gestão Luizianne Lins na Prefeitura de Fortaleza (2005-2012), a HABITAFOR assume a condução da política habitacional, centralizando a maioria das ações.

Estudos recentes apontam a existência de 856 assentamentos precários em Fortaleza, nos quais habitam $41,6 \%$ da população do município, concentrada em apenas $12 \%$ do território (FORTALEZA, 2016, p. 52). Desses assentamentos, 634 são favelas dispersas por toda a cidade, porém com uma maior presença nas regiões oeste e centro sul (FORTALEZA, 2013 e 2016). Ao longo dos recursos hídricos, na faixa litorânea e na periferia sul de Fortaleza, configuram-se os vetores de concentração de favelas (FORTALEZA, 2013) e corredores de degradação (PEQUENO, 2002). O déficit habitacional quantitativo, entendido como a necessidade de novas unidades habitacionais, atinge mais de 74.000 famílias (FORTALEZA, 2013).

Considerando este contexto, surge o interesse em realizar o trabalho que aqui apresentamos, de forma a contribuir com a consolidação das investigações acerca da produção contemporânea de habitação de interesse social (HIS) no município de Fortaleza, com enfoque na produção promovida pelo governo municipal. A escolha do tema de pesquisa também advém de nossa experiência de quase oito anos de trabalho na HABITAFOR. Inicialmente como estagiário e posteriormente como arquiteto e urbanista, o período na HABITAFOR nos possibilitou o envolvimento prático com a temática da HIS, procurando aplicar o conhecimento aprendido na universidade.

O recorte espacial da pesquisa foi limitado ao município de Fortaleza, e o objeto foi restringindo às intervenções de habitação social promovidas pela prefeitura no 
período após a criação do Ministério das Cidades (2003). A produção habitacional promovida através do Programa Minha Casa Minha Vida (PMCMV) não constitui nosso foco por entendermos que a participação do município na definição dos projetos é praticamente inexistente, ficando predominantemente sob a responsabilidade das construtoras e da CAIXA. Contudo, compreendendo o reflexo que o PMCMV teve sobre a política habitacional no município, referências ao programa foram necessárias em alguns momentos da pesquisa.

\section{Objetivos}

Estabelecemos como objetivo geral da pesquisa a análise do impacto da atuação do Ministério das Cidades na política municipal de HIS em Fortaleza, visando identificar o reflexo das diretrizes estabelecidas no padrão das intervenções realizadas pelo município no que se refere à localização das intervenções e a seus aspectos urbanísticos. Para isso, destacamos três objetivos específicos, que nortearam o desenvolvimento da pesquisa:

- Reconstituir o processo histórico que levou a HABITAFOR a se tornar o principal órgão condutor da política habitacional no município de Fortaleza;

- Analisar os efeitos das diretrizes concebidas pelo Ministério das Cidades sobre as intervenções habitacionais promovidas pela Prefeitura de Fortaleza;

- Analisar o padrão de inserção urbana das intervenções habitacionais promovidas pela Prefeitura de Fortaleza no período pós-criação do Ministério das Cidades, considerando as seguintes variáveis: localização, mobilidade, infraestrutura, serviços urbanos e fluidez urbana.

\section{Estrutura da dissertação}

Considerando os objetivos estabelecidos para a pesquisa, estruturamos o trabalho em cinco partes. Na Introdução, apresentamos o objeto da pesquisa, seus objetivos e sua estrutura. 
No primeiro capítulo, realizamos um resgate histórico do processo que levou à instituição da HABITAFOR enquanto principal órgão responsável pelas ações habitacionais do município de Fortaleza. Partimos do período da redemocratização do Brasil, marcado, no que se refere à política habitacional, pela extinção do BNH (1986), pela promulgação da Carta Constitucional (1988) e pela implementação de programas habitacionais alternativos, chegando até o período mais recente, com a criação do Ministério das Cidades (2003), a estruturação do Sistema Nacional de Habitação de Interesse Social (SNHIS) e seus reflexos em Fortaleza.

O segundo capítulo apresenta uma caracterização das intervenções promovidas pela Prefeitura de Fortaleza no período após a criação do Ministério das Cidades, quanto ao tipo e porte das intervenções, bem como no que se refere às tipologias habitacionais utilizadas. Ainda neste capítulo, realizamos uma síntese das diretrizes concebidas pelo Ministério das Cidades que deveriam orientar a elaboração dos projetos por parte dos interessados em captar recursos através do Fundo Nacional de Habitação de Interesse Social (FNHIS) para a implementação de intervenções.

A análise da inserção urbana de dois estudos de caso é abordada no terceiro capítulo. Selecionamos a intervenção Maravilha e o conjunto Maria Tomásia por suas localizações opostas na cidade: o primeiro, próximo da área central de Fortaleza; e o segundo, implantado na periferia sul da cidade. Através da metodologia de análise, definida para as variáveis localização, mobilidade, infraestrutura, serviços urbanos e fluidez urbana, pretendemos verificar o impacto no acesso ao direto à cidade que a implantação em áreas tão distintas pode trazer para as famílias.

Por fim, nas considerações finais, apresentamos uma síntese dos resultados obtidos na pesquisa. 
Habitação social em Fortaleza-CE pós Ministério das Cidades / Capítulo 01 - Página | 31

CAPÍTULO 01 - RESGATE HISTÓRICO 
Este capítulo tem como objetivo reconstituir o processo histórico que levou a Fundação de Desenvolvimento Habitacional de Fortaleza (HABITAFOR) a se tornar o principal órgão condutor da política habitacional no município de Fortaleza. Procuramos iluminar os arranjos institucionais, bem como identificar os agentes envolvidos na concepção e implementação das ações de modo a responder às seguintes questões norteadoras: Quando e como surgiu a HABITAFOR? Como a HABITAFOR operava? Que projetos habitacionais foram desenvolvidos pelo município de Fortaleza no período após a criação do Ministério das Cidades? Que agentes se relacionavam na condução da política habitacional em Fortaleza neste período? Que papéis cada agente desempenhava? Que relações os agentes estabeleceram entre si no desenvolvimento da política?

Sem abandonar o foco na análise da produção habitacional em Fortaleza no período pós Ministério das Cidades, foi necessário um recuo temporal até meados dos anos 1980 para uma melhor compreensão do processo histórico. Desta forma, podemos perceber a instituição da HABITAFOR enquanto um reflexo das políticas habitacionais pensadas a nível nacional, de modo que, sem obliterar o foco no município de Fortaleza, tornou-se evidente a necessidade de uma abordagem considerando diversas escalas, em especial a federal, cujos programas têm implicações diretas nas ações locais.

Assim, como recurso metodológico, recorremos a uma periodização da política habitacional em Fortaleza no período após a extinção do BNH. Com base em mudanças político-administrativas e institucionais, foram estabelecidos três momentos: 1. Um primeiro momento anterior à criação da HABITAFOR, no qual extinguiu-se a Fundação do Serviço Social de Fortaleza (FSSF) e surgiu a Comissão de Implantação de Projetos Habitacionais de Interesse Social e Infraestrutura (COMHAB); 2. Um segundo momento, no qual a COMHAB foi transformada em Fundação de Desenvolvimento Habitacional de Fortaleza (HABITAFOR); 3. E um terceiro momento, no qual a Fundação se torna a Secretaria do Desenvolvimento Habitacional de Fortaleza que, mantendo sua sigla, continuou a ser conhecida como HABITAFOR e passou a constituir um órgão da administração direta municipal. 


\subsection{A atuação da Comissão de Implantação de Projetos Habitacionais de Interesse Social e Infraestrutura Urbana (COMHAB)}

Em 1985, no início da Nova República, após mais de duas décadas de ditadura, o quadro existente no setor habitacional ${ }^{2}$ era de "baixo desempenho social, alto nível de inadimplência, baixa liquidez do sistema, movimentos de mutuários organizados nacionalmente e grande expectativa de que as novas autoridades pudessem resolver a crise do sistema sem a penalização dos mutuários" (AZEVEDO, 2007, p. 15).

Assim, enquanto a expectativa que se tinha do governo José Sarney (1985-1990) era de que houvesse uma reestruturação do Sistema Financeiro da Habitação (SFH), o que ocorre na realidade é a extinção do Banco Nacional da Habitação $(\mathrm{BNH})^{3} \mathrm{em}$ 1986, marcando o início de uma fase para a política habitacional no Brasil que foi caracterizada pela fragmentação e desarticulação das ações. Observamos neste período: a criação de programas alternativos marcados pela descontinuidade, pelo recurso à autoconstrução ${ }^{4}$ e pela urbanização de assentamentos precários como forma de redução nos custos das intervenções; constantes mudanças institucionais ${ }^{5}$, com a alocação da questão habitacional em diversos ministérios; reduções orçamentárias e restrições no acesso aos recursos; progressiva diminuição da atuação dos governos estaduais no setor habitacional, com a extinção de várias Companhias de Habitação (COHAB's); e uma hegemonia dos princípios neoliberais na concepção e condução das políticas de habitação (PEQUENO, 2008).

Além disso, a fragilidade das políticas federais elaboradas após o fim do $\mathrm{BNH}$, a redefinição institucional promovida pela Constituição Federal de 1988 e as iniciativas de governos locais progressistas, eleitos após a redemocratização do Brasil, refletiram um processo de descentralização "perversa" e municipalização de políticas setoriais,

\footnotetext{
2 Sobre a herança da política habitacional do regime militar, ver Maricato (1998, p. 4).

3 O BNH foi extinto pelo Decreto-lei no 2.291, de 21 de novembro de 1986. O mesmo decreto-lei estabeleceu a Caixa Econômica Federal (CEF) como a sucessora do BNH "em todos os seus direitos e obrigações" (BRASIL, 1986).

${ }^{4}$ Sobre a autoconstrução e seu papel no processo de produção da cidade, ver Oliveira (2013, p. 59), Rodrigues (1990, p. 32) e Rufino (2012, p. 112-113).

${ }^{5}$ Arretche (1996, p. 81) e Bonduki e Rossetto (2008, p. 7) descrevem a "via-crucis institucional" pela qual passou a questão habitacional na Nova República. A fragilidade institucional a nível Federal se rebate nas demais esferas de governo, como percebemos no caso de Fortaleza abordado nesta pesquisa.
} 
como a habitacional, ao privilegiar espaços e administrações que já acumulavam um maior volume de recursos financeiros, técnicos e administrativos (CARDOSO, 2001). Para Arretche (1996, p. 85, grifo no original), sobretudo na segunda metade dos anos 1980, observa-se:

\begin{abstract}
"a ausência progressiva do Governo Federal no setor, seja pela incapacidade de formular uma política capaz de reorganizar a produção e distribuição de unidades residenciais, seja por uma política de cortes nos gastos públicos que solapou as bases de financiamento dos programas sociais de habitação".
\end{abstract}

Desta forma, há um esforço de estados e municípios no sentido de constituir mecanismos locais de formulação e implementação de programas habitacionais.

$\mathrm{Na}$ esfera estadual, tem início o chamado "Governo das Mudanças"6 com a primeira administração de Tasso Jereissati pelo PMDB (1987 a 1991). Com ênfase no processo de modernização da estrutura administrativa, seu programa de governo possuía dentre os objetivos: a eliminação do clientelismo político, do empreguismo no setor público, da má aplicação dos recursos e da falta de transparência nas ações do estado; a luta contra a situação de miséria que atinge a maioria da população; a viabilização de canais de participação; e o estímulo à mobilização social (BRAGA, 1995, p. 206).

No âmbito da política habitacional, sua atuação foi marcada, de um lado, pelo esvaziamento político da Fundação Programa de Assistência às Favelas da Zona Metropolitana de Fortaleza (PROAFA) ${ }^{7}$ a partir de 1987, cuja imagem era fortemente

\footnotetext{
6 O termo "Governo das Mudanças" tinha, ao menos no discurso, um sentido de oposição à política autoritária e clientelista praticada pelos coronéis reformados do Exército Virgílio Távora, Adauto Bezerra e César Cals, que se alternaram no poder durante 16 anos (BRAGA, 1995, p. 185). Desta forma, as gestões ocorridas entre 1987-2007, que tiveram como governadores do estado do Ceará Tasso Jereissati (1987-1991), Ciro Gomes (1991-1994), Tasso Jereissati novamente (1995-1998 e 1999- 2002) e Lúcio Alcântara (2003-2006), instauraram um novo projeto político de desenvolvimento ligado à burguesia industrial cearense, que foi denominado "Governo das Mudanças". Sobre esse novo projeto de desenvolvimento, Bernal (2004, p. 61) entende que "o governo do Ceará [...] elegeu a 'guerra fiscal' como estratégia de atração de capitais privados, sob duas formas: oferecendo infraestrutura, incentivos fiscais e mão de obra barata para a relocalização de indústrias oriundas de velhas áreas industriais fordistas do Sul e Sudeste [...] e investindo na implantação de um vigoroso pólo turístico em Fortaleza". A opção pelo desenvolvimento do turismo na capital terá forte implicação na execução das políticas habitacionais.
}

7 A PROAFA foi criada para implementar o programa PROMORAR, concebido pelo BNH como uma alternativa à política de construção dos grandes conjuntos periféricos, num período em que os recursos para habitação escasseavam, e como uma tentativa de focar as ações para a população com renda entre zero e três salários mínimos (BRAGA, 1995). Portanto, era um programa de apelo mais popular. Com a lei no 11.732, de 14 de setembro de 1990, a PROAFA foi incorporada à Fundação dos Serviços 
ligada à ex-primeira-dama do estado, Luíza Távora ${ }^{8}$, portanto, associada a seu opositor político, o ex-governador Virgílio Távora, e ao regime militar. A relação política que envolvia a PROAFA é abordada por Braga (1995, p. 159, acréscimos nossos):

A criação de uma instituição especificamente para administrar os recursos do BNH/PROMORAR ocorreu, em grande parte, em face do prestígio pessoal de Virgílio Távora que, naquele momento, era um dos dirigentes do partido no poder - o PDS [Partido Democrático Social, sucessor da ARENA que era o partido oficial do regime militar] - e amigo pessoal do Ministro do Interior [ao qual o BNH era subordinado], Mário Andreazza, com o qual tinha interesses políticos convergentes. Nessa época, Andreazza aparecia como um dos pretendentes a candidato à Presidência da República e Virgílio Távora tinha planos de ingressar no Senado Federal.

Por outro lado, diante da situação de grande desigualdade social e do crescimento do problema habitacional, especialmente na capital, Tasso precisava manter uma atuação nesta área como forma de conservar uma base de apoio popular. Em 1980, a população favelada em Fortaleza correspondia a $24 \%$ do total da população (BRAGA, 1995, p. 162), superando as estimativas da própria prefeitura, que previa cerca de $20 \%$ da população do município morando em favelas neste mesmo ano (FORTALEZA, 1973) ${ }^{9}$. Além disso, a própria "retomada do mecanismo eleitoral coloca aos governos locais - quer municipais, quer estaduais - a necessidade de um certo grau de permeabilidade às demandas dos movimentos sociais organizados" (ARRETCHE, 1996, p. 83).

Desse modo, a Companhia de Habitação do Ceará (COHAB-CE), que já executava ações habitacionais no período do $\mathrm{BNH}$, com os grandes conjuntos ${ }^{10}$ das décadas de

Sociais do Estado do Ceará (FUNSESCE), que passou a se chamar Fundação de Ação Social (FAS), e suas funções pertinentes à construção de unidades habitacionais foram absorvidas pela COHAB-CE (CEARÁ, 1990), inclusive parte dos funcionários levaram a experiência e o conhecimento adquiridos nas ações da PROAFA.

8 Primeira-dama do Ceará nos dois mandatos de Virgílio Távora (1963-66 e 1979-82), governador no período do regime militar. Luíza Távora ficou conhecida como "mãe dos pobres" por suas obras de caridade e sua ação a frente da PROAFA, com a construção de conjuntos habitacionais por meio de mutirões.

9 Para se ter uma ideia da dimensão do problema, São Paulo, a maior cidade brasileira, possuía cerca de 71.840 pessoas morando em favelas, $1,06 \%$ de sua população municipal, segundo o Cadastro de Favelas de 1973, e saltou para 335.334 em 1980, o equivalente a 4,07\% da população, conforme o censo do IBGE (PASTERNAK, 2006, p. 187). Para o mesmo ano de 1973, Fortaleza já apresentava uma população moradora de favelas da ordem de 205.506 habitantes, cerca de $20,59 \%$ da população do município (FORTALEZA, 1973, p. s/n).

10 Ver Máximo (2012). 
1970 e 1980, e a Secretaria de Desenvolvimento Urbano (SDU) foram designadas para assumir no âmbito do Governo do Estado do Ceará (GEC) a execução do Programa Nacional de Mutirões Habitacionais, criado pelo governo federal em 1987 e implementado pela Superintendência Regional da Secretaria Especial de Ação Comunitária (SEAC) no Ceará (BRAGA, 1995). Arretche (1996, p. 81) também aponta uma dificuldade de se ter informações reais sobre o programa de mutirões "dado que a liberação dos recursos não estava vinculada seja a uma prestação de contas, seja à comprovação da efetiva construção de unidades habitacionais" e ressalta acusações de uso clientelístico, pois a liberação de recursos estaria associada ao apoio político.

Para Pequeno (2011), o Governo do Estado possuía duas linhas de atuação na área habitacional. A primeira associada ao Programa Nacional de Mutirões Habitacionais e às Sociedades Comunitárias Habitacionais $(\mathrm{SCH})^{11}$, do governo Sarney, com ações de menor porte, mais pulverizadas na cidade. Um de seus objetivos era a ampliação do apoio popular, com a criação de um lastro político, que muitas vezes se dava através de cooptação de lideranças populares.

A segunda linha de atuação se relacionava a projetos estratégicos em áreas de interesse do mercado imobiliário, visando o fortalecimento do turismo na capital. Nessas intervenções, a opção pela remoção completa das comunidades, ou de parte delas, para a realização de obras de urbanização, denotava um caráter higienizador. Como exemplo, Pequeno (2011) cita intervenções em áreas como o Castelo Encantado ${ }^{12}$, o Morro Santa Terezinha, o Serviluz e o riacho Maceió que se relacionam à área de interesse imobiliário e turístico da Beira-mar. Considerando-se o aspecto estratégico de tais ações, havia uma pressa por parte do governo na sua

\footnotetext{
11 "A criação das $\mathrm{SCH}$ e a assinatura de convênios a nível de cada área de atuação do Mutirão Habitacional foram algumas das exigências que a SEAC [Secretaria Especial de Habitação e Ação Comunitária], através do Programa Mutirão, impunha às organizações de bairros. [...] Conforme 0 estatuto padrão elaborado pela SEAC o Conselho das SCH teria a seguinte composição: três representantes do poder público, um da SEAC, um da COHAB, outro da SDU, e três da comunidade" (BRAGA, 1995, p. 215, acréscimo nosso).

12 Segundo Pequeno (1999), a intervenção no Castelo Encantado, mais especificamente no trecho do Morro do Teixeira, foi uma das ações realizadas pelo Governo do Estado em Fortaleza, dentro do programa Pró-Moradia. O autor aponta que a qualificação urbana do Castelo Encantado viabilizaria o desenvolvimento de projetos como a implantação do Anel Expresso Central, margeando o ramal ferroviário em direção ao porto do Mucuripe, o Projeto Fortaleza Atlântica de desenvolvimento da área da Beira-mar para lazer e turismo e a Expansão da Zona Industrial do Mucuripe. Mais recentemente a Prefeitura de Fortaleza, através da Secretaria de Turismo, iniciou uma nova intervenção de requalificação no Morro do Teixeira, com a execução de obras de contenção da encosta e a implantação de áreas de lazer.
} 
execução, por isso o mutirão não interessava devido à lentidão na execução e por exigir das comunidades um certo grau de organização social. Com o forçado esvaziamento político da PROAFA, ambas as linhas ações acabaram conduzidas pela COHAB-CE.

Na escala municipal, em meados dos anos 1980, as ações na área habitacional ainda eram conduzidas pela Fundação de Serviço Social de Fortaleza (FSSF), uma instituição criada em 1963 (BONDUKI, 2004, p. 122), antes mesmo do BNH e do SFH. Para melhor entendermos o contexto da política habitacional nesse período, realizaremos um breve recuo temporal a fim de compreender a atuação da FSSF.

Nos anos 1960, período em que a questão dos assentamentos precários se torna patente na cidade (FORTALEZA, 2001), a atuação da FSSF era marcada por um caráter assistencialista, no sentido da prestação de um serviço social a áreas de extrema pobreza, e desvinculado do setor de planejamento urbano, situação que perdurou por décadas (PEQUENO, 2008). Não havia uma intenção de se constituir uma política (urbana/habitacional) de enfretamento sistemático ao problema como forma de prevenir a ocorrência de novas ocupações, algo que só veio a emergir nos anos 1970, com a Política Nacional de Desenvolvimento Urbano (PNDU) ${ }^{13}$, concebida durante o regime militar (PEQUENO, 2011).

Durante os anos 1970, a ação da FSSF pautou-se pelo Programa Integrado de Desfavelamento, criado em 1973. Pretendia-se extinguir 32 dos 83 núcleos favelados mapeados pelo município (ver Mapa 3 e Mapa 4), seguindo uma lógica de remoção total e reassentamento da população em conjuntos habitacionais localizados em áreas

\footnotetext{
${ }^{13}$ Durante os governos militares, o planejamento urbano e regional ganha destaque, mesmo que com um caráter tecnocrático. Desta forma, foram concebidos os Planos Nacionais de Desenvolvimento (PND) I e II. No âmbito do II PND, foi concebida em 1973 a PNDU, que constituiu seu capítulo 4. Conforme Souza (2010), buscava-se vincular a política urbana à política global de desenvolvimento no país. Contudo a política urbana implementada foi bastante distinta da concebida. Para a autora, a grande dificuldade foi de cunho político e metodológico: os economistas no poder mantinham uma visão contábil da sociedade; a política urbana proposta contrariava determinados interesses econômicos; e o mercado buscava ter uma participação na condução desta política. A PNDU acabou trazendo diretrizes antagônicas ao próprio II PND, que tinha um caráter mais centralizador. No contexto local de Fortaleza, podemos citar a elaboração do Plano de Desenvolvimento Integrado da Região Metropolitana de Fortaleza - PLANDIRF (1972), o Programa Integrado de Desfavelamento de Fortaleza (1973) e a criação da Região Metropolitana de Fortaleza - RMF (1974) como decorrências desse processo de planejamento desencadeado a nível nacional. No documento da nova PNDU, publicado em 2004 durante o primeiro governo de Lula, há o entendimento de que "a aplicação destes planos [diretores] a uma parte das cidades ignorou as condições de assentamento e as necessidades da grande maioria da população urbana" (BRASIL, 2004b, p. 9, acréscimo nosso).
} 
periféricas da cidade, como podemos apreender das áreas selecionadas para receber esses conjuntos, assinaladas no Mapa 5. Conforme o documento Estudo Preliminar, o programa apresentava como objetivos básicos:

Primeiro - projetos de desfavelamento, através de "ação corretiva" das zonas marginais, quando se evidencia como necessária a remoção dos seus ocupantes. Remoção esta, exigida por forças intrínsecas do desenvolvimento urbano de Fortaleza, quer, por um lado, a ampliação do sistema viário, quer, por outro lado, pela mudança do uso do solo, ou seja, outras funções urbanas invadindo, por fatores circunstanciais desse mesmo processo, áreas que anteriormente eram definidas por outro tipo de ocupação, ou eram áreas desocupadas. [...]. Segundo, propor medidas de ação preventiva, ou seja, de recuperação dos núcleos cuja erradicação não será necessária e que, inclusive, apresentem alto potencial de renovação urbana (FORTALEZA, 1973, p. s/n, grifos nossos).

Mapa 3 - Favelas no espaço urbano de Fortaleza em 1973

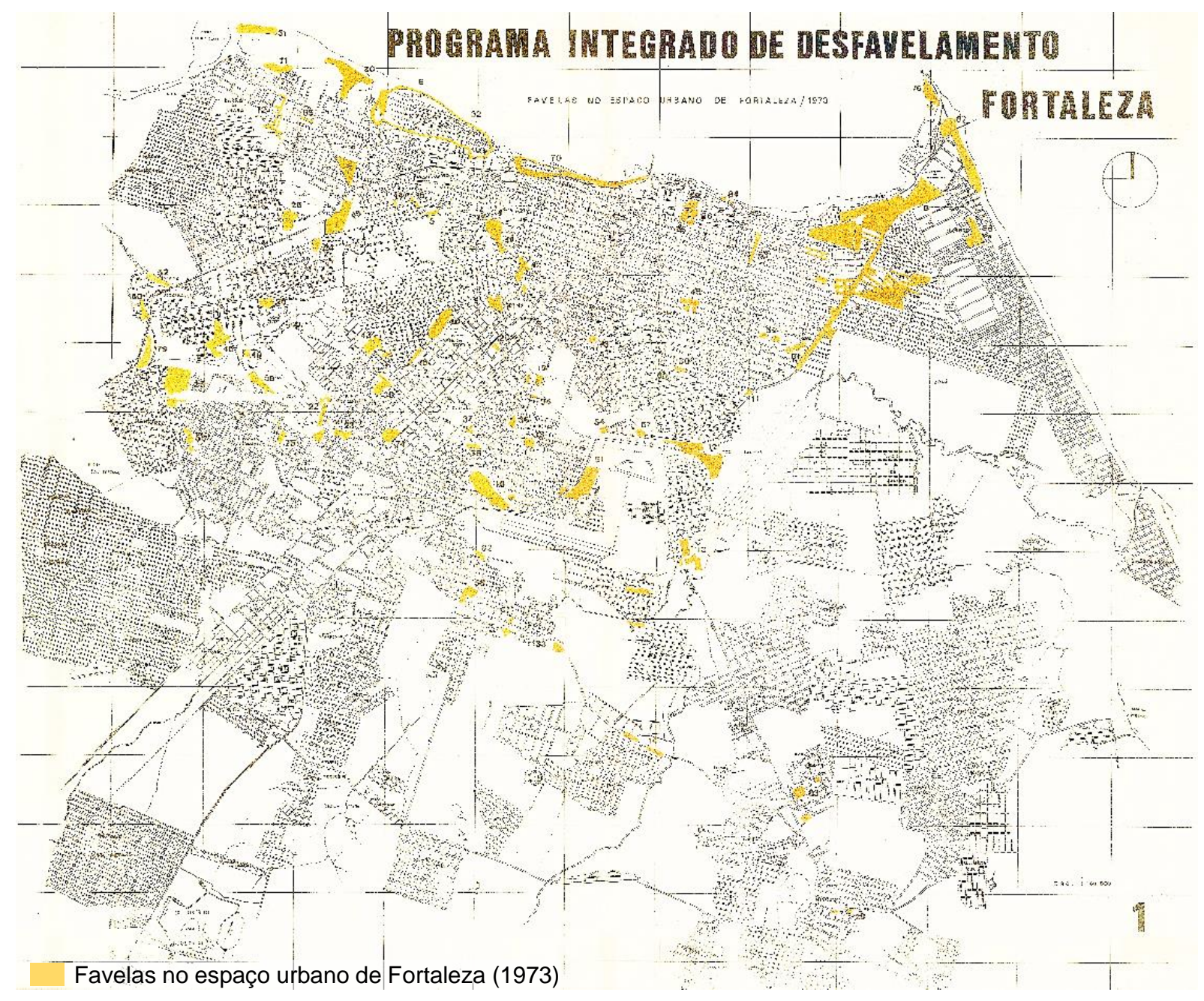

Fonte: Programa Integrado de Desfavelamento (FORTALEZA, 1973) 


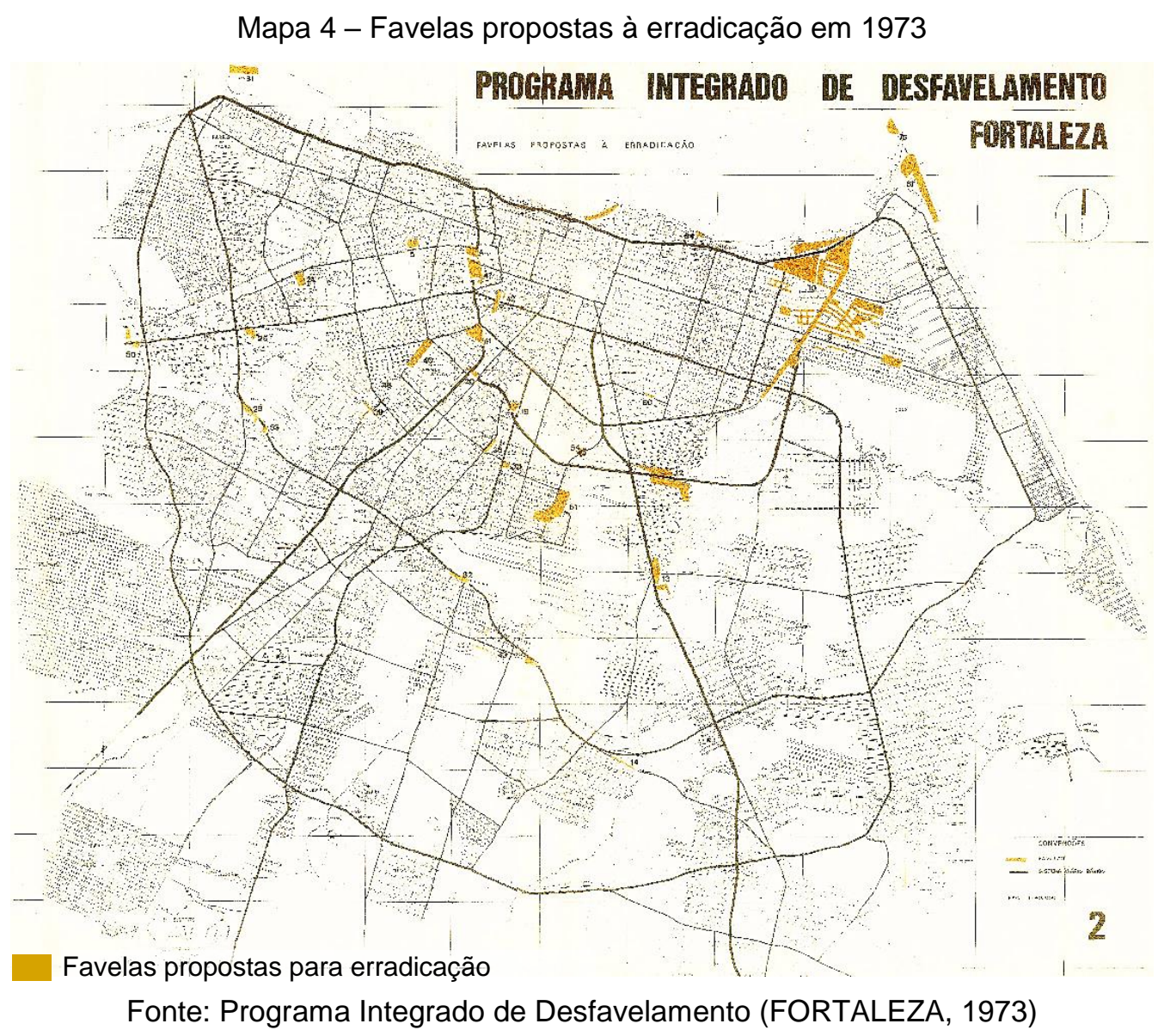

Mapa 5 - Áreas propostas para nucleamentos habitacionais de desfavelados

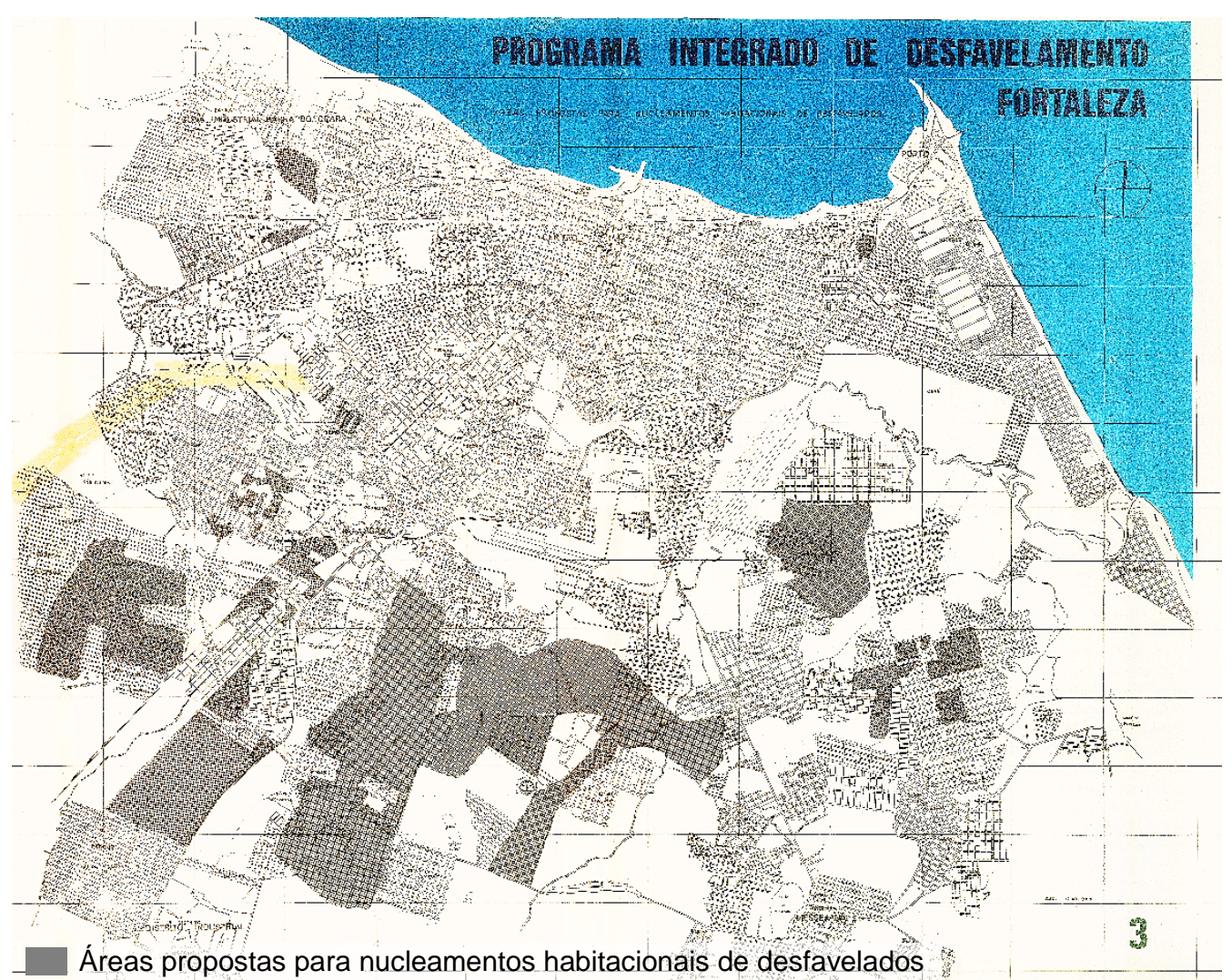

Fonte: Programa Integrado de Desfavelamento (FORTALEZA, 1973) 
Após este breve hiato, retornamos ao cenário de Fortaleza nos anos 1980. Na primeira eleição para a prefeitura após o regime militar, ocorreu a inusitada vitória de Maria Luiza Fontenele, pelo PT, em 1985, contrariando as pesquisas que apontavam Paes de Andrade, do PMDB, como vencedor do pleito. A primeira mulher eleita prefeita de uma capital no Brasil enfrentou uma gestão turbulenta, como relembram os trechos abaixo de uma matéria do jornal O Povo:

Dividida em um racha político, a gestão conviveu de início com
herança de dívidas, acúmulo de lixo em toda a cidade e período de
fortes chuvas. O Município sofria ainda efeitos da seca de 1983, que
trouxera levas de retirantes. [...]. Com dois meses de gestão, a
primeira greve de servidores. Só de motoristas de ônibus, foram sete.
Greves também pararam o IJF [importante hospital da capital],
chegando a provocar mortes por falta de atendimento. [...]. Sem
autonomia financeira, a gestão foi prejudicada por boicotes dos
Governos Estadual e Federal, ambos opositores. Inadimplência
provocou até bloqueio de repasses ao Município. Maria jogou a culpa
no governo José Sarney (PMDB), chegando a fazer greve de fome
como protesto. [...]. No início da gestão, aliados da prefeita acusaram
o governo do estado de espalhar lixo pelas ruas de Fortaleza (O
POVO, 2015). No tocante à questão habitacional, a gestão de Maria Luiza, através do Departamento de Habitação da FSSF, assumiu uma postura de crítica em relação ao Programa Nacional de Mutirões Habitacionais e, por vezes, de desconhecimento das normas operacionais do programa (BRAGA, 1995). Além disso, a situação de crise financeira enfrentada pela prefeitura limitava sua participação em relação às exigências do programa, como a desapropriação da área e a construção da infraestrutura urbana (BRAGA, 1995), o que resultou numa produção ínfima, ainda mais quando a comparamos com a do governo do estado (Quadro 1).

Os projetos de mutirões desenvolvidos pela prefeitura nesse período, fim dos anos 1980, atenderam, em sua maioria, a grupos de ocupações recentes de terra urbana que contaram com o apoio do executivo municipal (BRAGA, 1995, p. 223). Essa "permissão" em relação às ocupações seria uma forma de a prefeita garantir um mínimo de apoio da população, tendo em vista a oposição política e a crise econômica que sua gestão enfrentava (PEQUENO, 2011). 
Quadro 1 - Mutirão Habitacional: (1) casas previstas e (2) concluídas em Fortaleza entre 1987 e 1989

\begin{tabular}{l|c|c|l|c|c}
\hline \multicolumn{3}{c}{ Convênios SEAC / Governo Estadual / Prefeitura de Fortaleza } \\
\hline \multirow{2}{*}{ Áreas } & \multicolumn{2}{|c|}{ Estado } & \multirow{2}{*}{ Áreas } & \multicolumn{2}{c}{ Prefeitura } \\
\cline { 2 - 4 } & \multicolumn{2}{|c}{ No casas } & \multicolumn{2}{c}{ № casas } \\
\cline { 2 - 3 } & $\mathbf{( 1 )}$ & $\mathbf{( 2 )}$ & & $\mathbf{( 1 )}$ & $\mathbf{( 2 )}$ \\
\hline Pirambu & 1.000 & 359 & Nova Jerusalém & 576 & 166 \\
Serviluz & 400 & 104 & São Francisco & 31 & 31 \\
Cristo Redentor & 500 & 161 & Boa Vista (I e II) & 134 & 29 \\
Jardim Iracema & 114 & 114 & Jardim Iracema & 44 & 44 \\
Ipaumirim & 100 & 100 & Jangurussu & 75 & 6 \\
Jangurussu & 100 & 90 & Nova Esperança & 98 & 95 \\
Parque São Miguel & 560 & 188 & Santa Rita & 27 & 27 \\
Lagamar & 400 & 390 & & & \\
BR-116 / Aerolândia & 438 & 438 & & & \\
Jardim União & 509 & 300 & & $\mathbf{9 8 5}$ & $\mathbf{3 9 8}$ \\
\hline Total & $\mathbf{4 . 1 2 1}$ & $\mathbf{2 . 2 4 4}$ & & & \\
\hline
\end{tabular}

Notas: (1) Casas previstas; (2) Casas construídas; algumas das casas previstas foram construídas posteriormente (1990 - 1991) com recursos estaduais e municipais.

Fonte: COHAB-CE e Prefeitura Municipal de Fortaleza apud Braga (1995)

Com as atribulações enfrentadas por seu governo, Maria Luiza não conseguiu eleger um sucessor. Ciro Gomes (PSDB) assumiu a prefeitura em 1989, porém logo renunciou a fim de se candidatar ao governo do estado, com o apoio de Tasso Jereissati, cargo que exerceu entre 1991 e 1994. Em abril de 1990, assume a administração municipal o vice-prefeito Juraci Magalhães que lograria mais tarde eleger seu sucessor, Antônio Cambraia (1993-1996), e eleger-se novamente por mais dois mandatos (1997-2000 e 2001-2004).

Nesse período, como já mencionamos, a Constituição aprovada em 1988 apontou para a municipalização de diversas políticas setoriais, dentre elas a de habitação. Deste modo, no final dos anos 1980 e início dos 1990, enquanto o governo federal praticamente se ausenta da formulação de programas e diretrizes, ocorre também uma progressiva redução na atuação do governo estado, que culminará com a extinção da COHAB-CE em 1999. Por sua vez, os governos municipais precisaram assumir o enfrentamento da questão habitacional, ou ao menos dar alguma resposta aos movimentos sociais que vinham se organizando desde os anos 1970 na luta pela redemocratização, pela Reforma Urbana e durante o processo da Constituinte. 
Algumas mudanças podem ser ressaltadas na gestão Ciro/Juraci, no âmbito da política habitacional. A primeira delas foi a aprovação da lei $n^{\circ} 6.543$, de 1989, que alterou a lei municipal de parcelamento do solo, lei n 5.122-A, de 1979, passando a exigir a doação de 5\% da área de novos parcelamentos de glebas para a implantação de programas habitacionais de interesse social. Contudo, no que se refere à garantia de terrenos localizados em áreas com oferta de infraestrutura, equipamentos e serviços públicos, a mesma lei permitiu que a doação pudesse ser feita em outro local a escolha da prefeitura, desde que o terreno possuísse o mesmo valor e permitisse a implantação de programa igual ao previsto no terreno original (FORTALEZA, 1989b), o que acabou levando à doação de terrenos na periferia de Fortaleza, distantes das áreas de origem dos parcelamentos.

A aprovação da lei n 6.541 de 1989 que criou o Fundo de Terras foi outra mudança. Este fundo tem como objetivo a criação de uma reserva de terrenos para a implantação de programas habitacionais de interesse social, devendo receber o percentual de áreas doadas por novos parcelamentos de glebas, terrenos de propriedade municipal ou objeto de transferência da União ou Estado para o Município, bem como áreas desapropriadas para intervenções de habitação de interesse social (FORTALEZA, 1989a).

Na gestão Ciro/Juraci também foi instituída a Comissão para Implantação de Projetos Habitacionais de Interesse Social e Infraestrutura Urbana (COMHAB) pelo decreto de no 8.130, de 29 de novembro de 1989. A COMHAB estava diretamente ligada ao gabinete do prefeito (FORTALEZA, 1989c). Máximo (2012, p. 170) relaciona sua criação a uma "necessidade de mudança nas práticas assistencialistas realizadas pela FSSF" de forte caráter clientelista. Contudo, Pequeno (2011) observa que na realidade houve justamente uma continuidade dessas práticas, pois até mesmo funcionários da FSSF foram transferidos para a COMHAB, inclusive seu diretor, Roberto da Frota Cavalcante ${ }^{14}$, que assumiu a coordenação do novo órgão.

Pelo estabelecido no decreto n 8.130/1989, percebemos que a COMHAB foi criada como um órgão executivo, possuindo dentre suas competências: a elaboração de

\footnotetext{
14 "Roberto Cavalcante está envolvido com as ações na área de habitação no município desde a primeira gestão de Juraci Magalhães (1990-1992), quando o então prefeito de Fortaleza, Ciro Gomes, saiu para disputar o governo do Estado" (O POVO, 2004a).
} 
projetos de parcelamento do solo, de moradia, de esgotamento sanitário; a promoção de processos de regularização fundiária, com a assessoria da Procuradoria Geral do Município (PGM); o acompanhamento de obras; a coordenação da criação de Sociedades Habitacionais; e a coordenação do trabalho social nos projetos habitacionais (FORTALEZA, 1989c).

A equipe prevista inicialmente para a COMHAB contava com treze membros (um coordenador, nove técnicos e três apoios). Mesmo com a atuação de outros órgãos no setor habitacional, como o IPLAM e a Secretaria de Trabalho e Ação Social STAS, antiga FSSF (CABANNES, 1996), podemos considerar insuficiente a dimensão da equipe da COMHAB, tendo em vista o tamanho do problema a ser enfrentado. $\mathrm{E} o$ que já era exíguo ficou ainda pior com a reestruturação estabelecida no decreto no8.303, de 21 de maio de 1990, que reduziu a equipe da COMHAB para "um coordenador e três membros, auxiliados por dois assistentes técnicos e dois de apoio" (FORTALEZA, 1990), resultando num total de oito profissionais.

Desta forma, a COMHAB assumiu da FSSF a responsabilidade pela execução do programa de mutirões habitacionais, respondendo pelas ações de cadastro, projeto, obra, trabalho social e titulação dos imóveis (FORTALEZA, 2001). De modo geral, esta produção foi marcada pela implantação de pequenos conjuntos espalhados na malha urbana de Fortaleza. A escala reduzida e a dispersão pela cidade atendiam a critérios clientelistas, com a construção de unidades habitacionais relacionada à eleição de pessoas ligadas à COMHAB (MÁXIMO, 2012).

A produção de mutirões habitacionais pela COMHAB deu-se basicamente em terrenos do Fundo de Terras. Porém, a responsabilidade "pela definição da política habitacional, pela identificação de áreas e pelo gerenciamento do Fundo de Terras" ficou reservada à Secretaria do Planejamento Urbano e Meio Ambiente (SPLAM), através do Instituto de Planejamento do Município (IPLAM) (FORTALEZA, 1989c). Podemos observar no Mapa 6 as ações de mutirão implementadas pela Prefeitura de Fortaleza entre 1986 e 2004. 
Mapa 6 - Mutirões implantados pela Prefeitura de Fortaleza entre 1986 e 2004

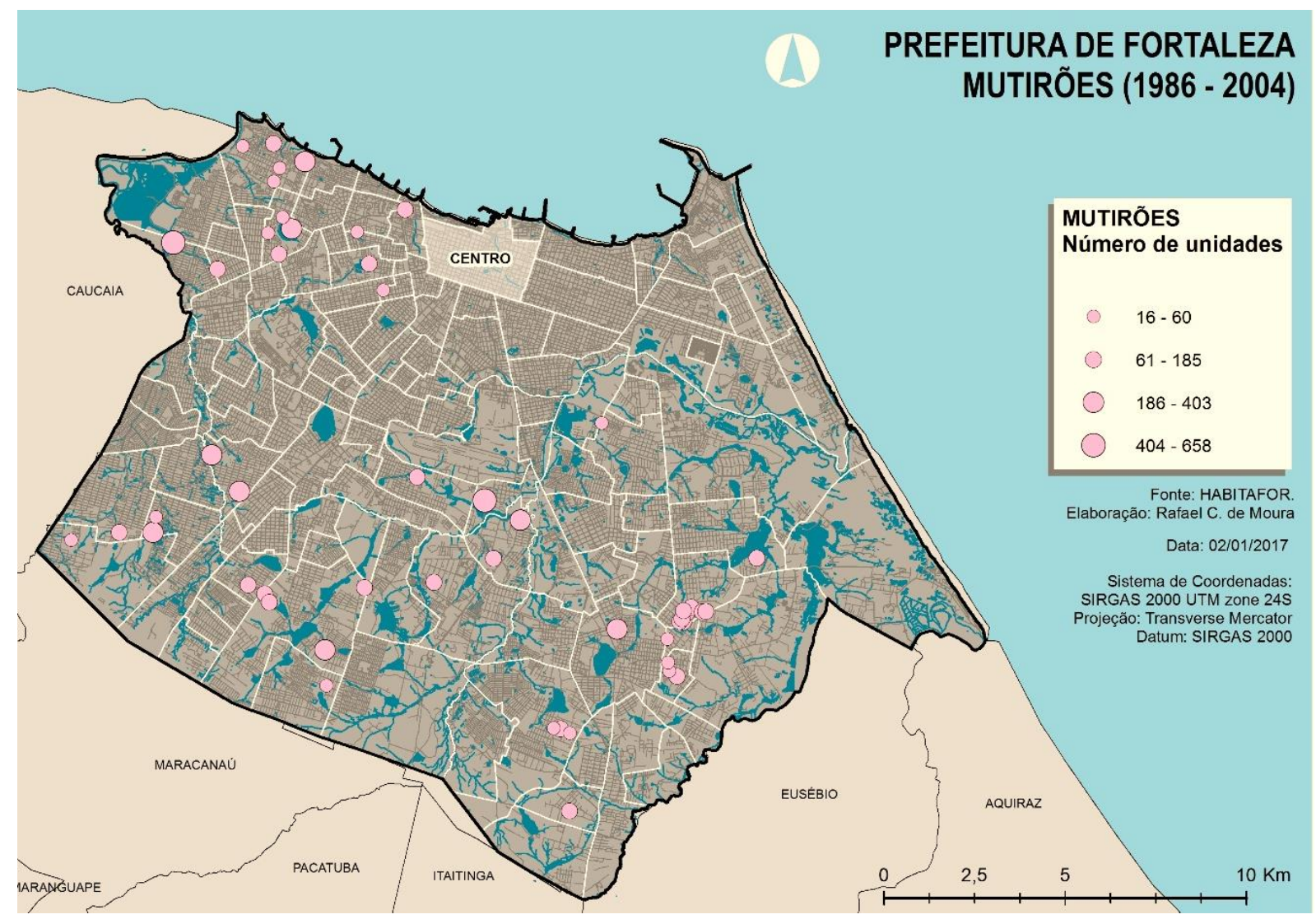

Fonte: Habitafor, elaboração do autor

Outra ação implementada pela COMHAB foi o programa ProRenda Urbano ${ }^{15}$, em parceria com a GTZ, uma Agência de Cooperação Técnica Alemã (Deutsche Gesellschaft für Teschnische Zusammenarbeit). O ProRenda Urbano foi concebido pela GTZ ainda na década de 1980, inserido na área temática de Desenvolvimento Urbano Regional Integrado em Áreas Menos Favorecidas. Possuía como objetivos a "melhoria da qualidade de vida das populações de baixa renda por meio do fortalecimento do exercício da cidadania, adequação de serviços públicos à demanda dos usuários, criação de oportunidades para atividades produtivas” (VALENTE, 2007, p. 223).

No entanto, somente após a Conferência das Nações Unidas sobre o Meio Ambiente, ECO 92, realizada na cidade do Rio de Janeiro em 1992, na qual o problema da

\footnotetext{
15 Para implementar o programa, a Prefeitura de Fortaleza instituiu o Fundo de Apoio aos Programas de Habitação e ao Projeto ProRenda, através da lei no 6.919, de 11 de julho de 1991. Este fundo tinha o objetivo de gerenciar os recursos financeiros destinados ao Programa Mutirão Habitacional e ao componente de infraestrutura do ProRenda e era administrado pelo coordenador da COMHAB (FORTALEZA, 1991).
} 
habitação foi apresentado sob um viés ambiental urbano, o ProRenda passa a ser implementado no Ceará, com ações voltadas para: a urbanização, centrada na questão do saneamento; o planejamento participativo, característico das agências de cooperação alemã ${ }^{16}$; e a construção de equipamentos sociais, geralmente a sede da associação dos moradores (PEQUENO, 2011).

Para Pequeno (2011) e Máximo (2012), a opção pelo estado do Ceará para a realização do ProRenda Urbano se deu pela relação próxima que havia com o governo federal. Por sua vez, a escolha de Fortaleza ocorreu pela enorme quantidade de favelas que a cidade possuía, mais de 300, conforme levantamento do Governo do Estado em 1991 (Mapa 7). Assim, foram escolhidas as áreas do Couto Fernandes, Lua Fumaça, Pirambu e Conjuntos Palmeiras para implementação do programa (FORTALEZA, 2003a), como representantes do universo de favelas de Fortaleza.

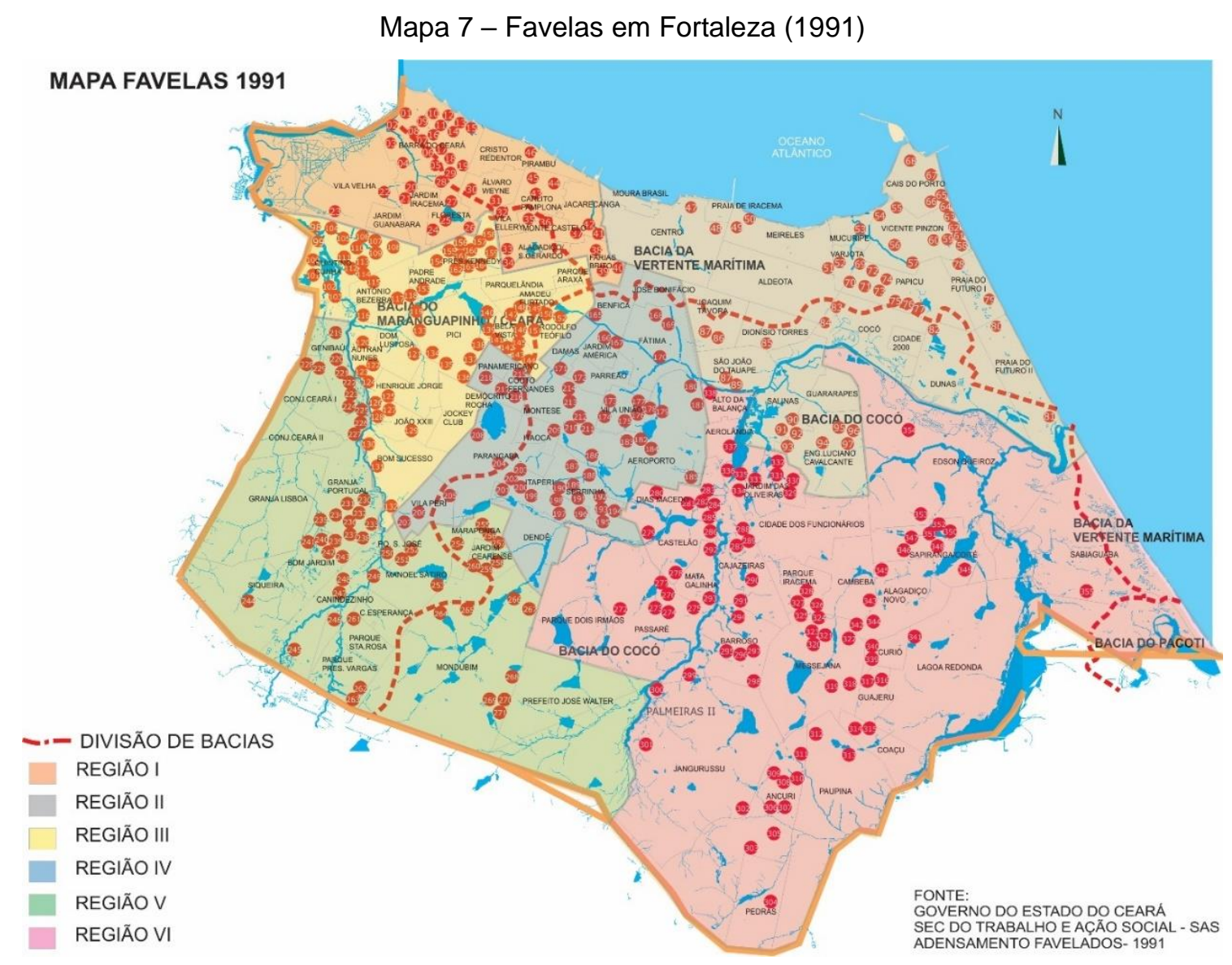

Fonte: Governo do Estado do Ceará, Secretaria do Trabalho e Ação Social (SAS)

16 "A cooperação alemã é representada a partir de seu caráter essencialmente participativo, sendo atribuído aos alemães o desenvolvimento de uma metodologia com esse perfil: o Planejamento de Projetos Orientado por Objetivos (Ziel Orientierten Projekt Planung) - ZOPP" (VALENTE, 2007, p. 210). 
Por conta do ProRenda Urbano, além dos mutirões habitacionais, a atuação da COMHAB passou também a abranger favelas em Fortaleza. Todavia, o controle estrangeiro dos recursos, que ficavam sob a responsabilidade de um consultor da GTZ, acabou dificultando sua utilização para fins clientelísticos, como a prática nos projetos de mutirão. Essa atuação diversificada da COMHAB irá habilitá-la para conduzir o Programa Habitar Brasil/BID (PHBB) em Fortaleza (PEQUENO, 2011), como veremos a seguir.

\subsection{A criação da Fundação do Desenvolvimento Habitacional de Fortaleza (HABITAFOR) e a ampliação da oferta dos recursos federais}

Durante o governo Collor (1990 - 1992), foi lançado o Plano de Ação Imediata para a Habitação (PAIH) que "se propunha a financiar em 180 dias cerca de 245 mil habitações" (AZEVEDO, 2007, p. 19). O programa apresentava três vertentes de atuação: o programa de moradias; o programa de lotes urbanizados; e o programa de ação municipal para habitação popular, no qual o papel de agente promotor caberia exclusivamente às prefeituras (AZEVEDO, 2007).

Em Fortaleza, o conjunto São Cristóvão foi o principal resultado do PAlH, por meio do Programa de Habitação Popular (PROHAP). Construído no período das gestões de Juraci Magalhães (1990 - 1992) e de Antônio Cambraia (1993 - 1996), o conjunto foi implantado na região sul da cidade, às margens da avenida Presidente Costa e Silva (Perimetral), distante aproximadamente treze quilômetros do centro de Fortaleza, com um total de 3.590 casas do tipo embrião, com $24 \mathrm{~m}^{2}$ de área construída, em lotes de $6 \times 22$ metros (MÁXIMO, 2012). A obra do conjunto foi dividida em cinco áreas e em cada uma delas a execução ficou sob a responsabilidade de uma construtora.

Anos depois, duas áreas no conjunto São Cristóvão se tornarão objeto de intervenção da HABITAFOR (Mapa 8). A primeira delas, o Campo Estrela e seu entorno, constituise de uma área verde doada pelo loteamento do conjunto São Cristóvão, conforme estabelecido na legislação de parcelamento do solo, destinada à implantação de equipamentos esportivos e de lazer, em parques e praças, que acabou sendo ocupada por famílias de baixa renda. A outra área, um terreno remanescente no loteamento original do São Cristóvão, foi utilizada pela prefeitura para um projeto em 
que lotes eram doados para famílias que ali deveriam erguer suas casas, porém nem todos os terrenos foram construídos.

\section{Mapa 8 - Conjunto São Cristóvão, Lotes Remanescentes e Campo Estrela}

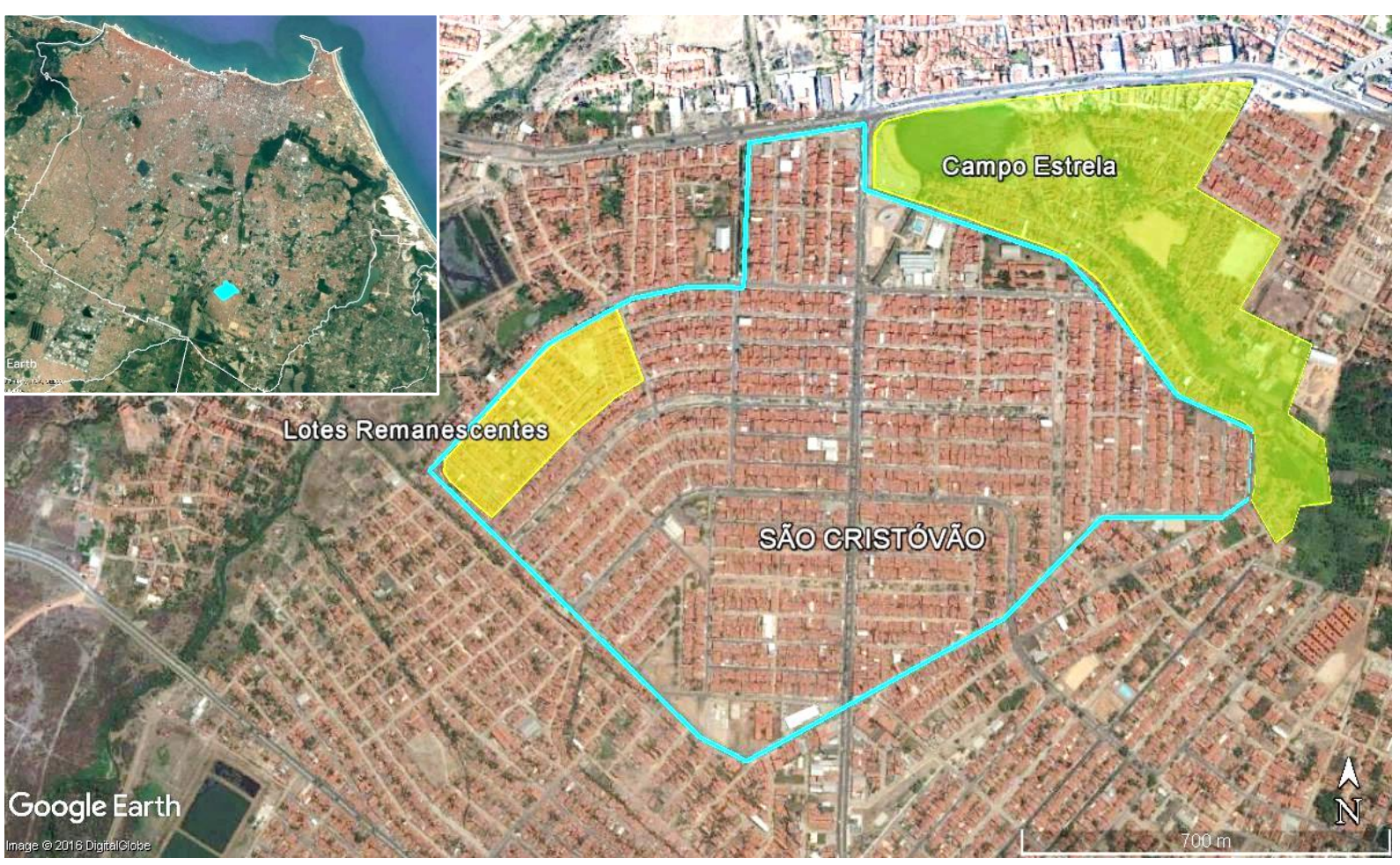

Fonte: Habitafor e Google Earth, elaboração do autor

Com a crise do SFH e o rombo no FGTS $^{17}$ aprofundados na gestão de Fernando Collor, o governo de Itamar Franco (1992 - 1994) buscou priorizar a conclusão das cerca de 260 mil casas financiadas por seu antecessor. Assim, foram criados o Programa Habitar Brasil (PHB), voltado para municípios com mais de 50 mil habitantes, e o Morar Município, para municípios de menor porte, que operavam fora do SFH, como forma de centrar as ações habitacionais na população de baixa renda, já que a lógica de retorno dos investimentos, que vinha desde o período do $\mathrm{BNH}$, acabava por direcionar as ações aos setores da classe média (AZEVEDO, 2007). Os programas Habitar Brasil e Morar Município ou foram mantidos na gestão posterior,

17 Em 1991 o governo Collor facilitou "a quitação da casa própria pela metade do saldo devedor, ou pelo pagamento das mensalidades restantes sem correção e juros. Normalmente, a segunda opção de quitação foi a mais vantajosa, ocasionando na prática de subsídios substanciais. Permitiu-se também o uso do FGTS para a quitação antecipada. Boa parte dos mutuários de classe média logrou liberar seus imóveis por preços bastante acessíveis. O governo conseguiu momentaneamente aumentar o fluxo de caixa para financiamentos habitacionais, mas seguramente isso significou maiores subsídios e agravamento ainda maior da crise" (AZEVEDO, 2007, p. 20). 
ainda que com modificações, ou serviram de base para a formulação de outros programas (SANTOS, 1999).

No governo de Fernando Henrique Cardoso (1995 - 2002) há uma reformulação na estrutura do Estado, com reformas (previdenciária, tributária...) que buscavam transformar o estilo de administração, com enfoque nos processos de implantação de políticas públicas em procedimentos de gerenciamento visando resultados (ARAGÃO, 2010, p. 35). No âmbito da questão habitacional, ocorre uma reestruturação do SFH e, em 1996, a Secretaria de Política Urbana, órgão que então era responsável pela questão habitacional, elabora uma proposta de Política Nacional de Habitação na qual Maricato (1998, p. 5) identifica como virtudes:

1 - O reconhecimento da cidade ilegal e, portanto, da extensão dos direitos e da cidadania; 2 - Novo conceito de déficit, incorporando a melhoria de áreas ocupadas precariamente aos programas da política urbana, além do conceito da casa pronta; 3 - Descentralização da operação dos programas de responsabilidade de governos municipais e estaduais; 4 - Diversidade de programas, rompendo com a rigidez e a padronização excessiva. (Os programais criados foram: Prómoradia, Habitar Brasil, Carta de Crédito Individual e Associativo e Apoio à Produção); 5 - Reconhecimento da importância da produção associativa privada não lucrativa (Carta de Crédito Associativo); 6 Reconhecimento da importância da questão fundiária e urbanística; 7 - Reconhecimento da relevância da participação democrática na gestão da política habitacional através da proposta do Conselho de Política Urbana; 8 - Reconhecimento de que o déficit habitacional se concentra de forma radical nas camadas de rendas mais baixas.

Apesar das boas intenções, na prática não houve uma repercussão significante no enfrentamento do problema da habitação (MARICATO, 1998), com um desempenho do governo, no que se refere à política de habitação popular stricto sensu, abaixo do planejado inicialmente, entre 1996 e 2000 (AZEVEDO, 2007).

No governo $\mathrm{FHC}$, os dois principais programas habitacionais voltados para ação em áreas degradadas e atendimento à população de baixa renda foram o Habitar Brasil e o Pró-moradia (SANTOS, 1999). O Habitar Brasil veio da gestão Itamar Franco e foi reformulado, recebendo verbas do Orçamento Geral da União (OGU) a fundo perdido. Em 1999, passou também a contar com empréstimo do Banco Interamericano de Desenvolvimento (BID), passando a se chamar Programa Habitar Brasil / BID (PHBB). O Pró-moradia, por sua vez, tinha como fonte de recursos o FGTS, o que estabelecia a necessidade de ressarcimento dos recursos e tornava as exigências financeiras em 
relação à capacidade de pagamento de estados e municípios mais rígidas do que no PHB (SANTOS, 1999). Outra diferença distingue os dois programas:

A diferença quanto à origem dos recursos reflete-se também na distribuição regional da disponibilidade. Enquanto, no caso do PróMoradia, a disponibilidade de recursos é definida a partir das normas técnicas de utilização do FGTS, no Habitar-Brasil é definida pelo Congresso Nacional, responsável pela aprovação final do Orçamento Geral da União. Assim, a ingerência de fatores políticos no segundo caso é claramente maior do que no primeiro (SANTOS, 1999, p. 24).

O Pró-moradia tinha a CAIXA como agente operador e possuía as seguintes modalidades: urbanização de áreas degradadas; produção de lotes urbanizados; cesta de materiais de construção; infraestrutura em conjuntos habitacionais e desenvolvimento institucional ${ }^{18}$ (FORTALEZA, 2003a).

O Pró-Moradia foi uma espécie de continuação do PROMORAR desenvolvido pelo BNH no final dos anos 1970 e início dos anos 1980 (PEQUENO, 2011). O Governo do Estado do Ceará, que implementou o PROMORAR através da PROAFA, passou a executar o Pró-Moradia por meio da COHAB-CE:

Desde o início da década de 1990, a COHAB-CE já vinha desenvolvendo programa de urbanização de favelas com recursos da CEF, porém de forma pontual, concentrado em setores estratégicos da cidade, que se preparava para assumir sua condição de destino turístico. Dentre as contribuições da COHAB para a questão das áreas de ocupação, merece destaque o ainda vigente Cadastro de Favelas de Fortaleza, feito em 1991, quando foram pesquisados e mapeados os 314 assentamentos favelados de Fortaleza (PEQUENO, 2008) (Mapa 7).

A acentuada redução do papel da $\mathrm{COHAB}$, pela necessidade de controle das dívidas do estado, e pela adoção da agenda neoliberal, termina com a extinção ${ }^{19}$ do órgão em 1999 e a transferência de suas atribuições para um "pequeno departamento ligado ao setor de infraestrutura, não mais voltando à atuação na provisão de moradia, mantendo-se timidamente à frente de projetos de urbanização de favelas vinculadas

\footnotetext{
18 Em 2007, a Instrução Normativa no 16, do Ministério das Cidades, readequou as modalidades do Pró-Moradia para: urbanização e regularização de assentamentos precários; produção de conjuntos habitacionais; e desenvolvimento institucional (BRASIL, 2007b).

${ }^{19}$ A Companhia de Habitação do Ceará - COHAB, instituída pela lei no 9.557/1971, foi extinta pela lei no 12.961, de três de novembro de 1999, que criou na estrutura do poder executivo estadual a Secretaria da Infra-Estrutura - SEINFRA para assumir as funções de planejamento e coordenação da política habitacional, dentre outras (CEARÁ, 1999).
} 
às grandes intervenções urbanas que o estado vinha fazendo na cidade" (PEQUENO, 2008). Restou ao município a responsabilidade de enfrentar os problemas habitacionais ${ }^{20}$, passando também a implementar o Pró-Moradia a partir da segunda metade dos anos 1990.

No executivo municipal, o Pró-Moradia tinha a Secretaria Municipal de Desenvolvimento Urbano e Infraestrutura (SEINF) na coordenação geral, responsável pela elaboração do projeto executivo, pela licitação das obras e pela coordenação do trabalho social. Às Secretarias Executivas Regionais ${ }^{21}$ (SER) estava reservado um papel de execução das ações, através: do cadastro das famílias; da seleção dos terrenos; da execução, fiscalização e acompanhamento das obras; e implantação do trabalho social (FORTALEZA, 2003a). Sua produção totalizou 6.152 unidades habitacionais no período entre 1998 e 2004 (Quadro 2 e Mapa 9).

\begin{tabular}{llll}
\multicolumn{4}{c}{ Quadro 2 - Produção do Pró-Moradia pela PMF } \\
\hline CONJUNTO & SER & ANO & UH \\
\hline Nova Descoberta & VI & 1998 & 152 \\
Santo Antônio da Floresta II & I & 1999 & 555 \\
Novo Barroso & VI & 1999 & 1030 \\
Lagoa Redonda & VI & 2000 & 320 \\
Itapery & IV & 2000 & 191 \\
Paupina & VI & 2000 & 904 \\
Planalto Pici & I & 2002 & 490 \\
Aracapé & V & 2002 & 1755 \\
Tatumundê & V & 2004 & 578 \\
Patativa do Assaré & VI & 2004 & 177 \\
\hline TOTAL & & & 6152 \\
\hline
\end{tabular}

Fonte: Habitafor, elaboração do autor

20 Para Pequeno (2011), "a política de habitação vai ter, nos primeiros anos, dificuldade de ser municipalizada porque as COHAB's ainda existem. O que vai acontecer é que, na década de 90, que o [Governo do] Estado vai começar a recuar. Vai ter o enxugamento da máquina administrativa. [...]. Na hora que os governos estaduais vão seguir a cartilha neoliberal, uma das áreas que vai sumir é o setor habitacional". Na realidade, houve uma pressão para que as prefeituras assumissem o tema.

${ }^{21}$ A lei no 8000, de 29 de janeiro de 1997, alterou a estrutura administrativa do executivo municipal e criou seis Secretarias Executivas Regionais (SER), espécie de subprefeituras, com a finalidade de prestar os serviços municipais, com ações de saúde, educação, cultura, lazer e outras ações sociais desenvolvidas na sua área de abrangência (FORTALEZA, 1997). 
Mapa 9 - Produção do Pró-Moradia pela PMF

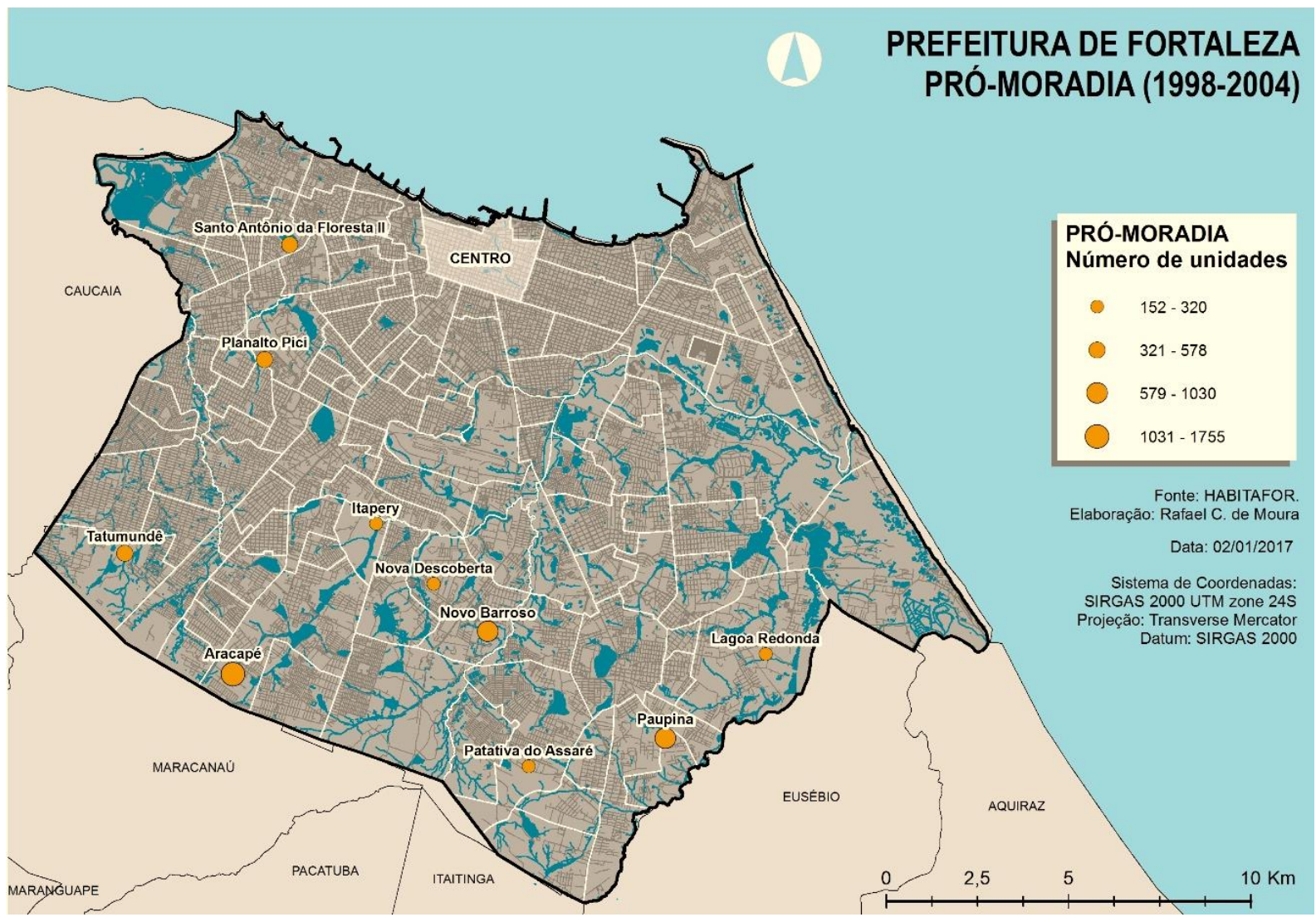

Fonte: Habitafor, elaboração do autor

A atuação das Regionais na implementação do Pró-moradia não escapou das práticas clientelistas. Seus respectivos secretários tornaram-se alvo de diversas acusações de uso dos programas habitacionais para se elegerem vereadores ${ }^{22}$. $\mathrm{O}$ caso mais notório foi o da vereadora Nelba Fortaleza, acusada de distribuir apartamentos no conjunto Tatumundê em troca de votos, inclusive para funcionários da Secretaria Executiva Regional que ela comandava, a SER-V (O POVO, 2004b, 2004c; DIÁRIO DO NORDESTE, 2004).

Por sua vez, o Programa Habitar Brasil/BID representou uma nova abordagem para a política habitacional, possibilitando uma maior participação do município. Segundo o Manual do programa, o PHBB tinha como objetivo:

contribuir para elevar a qualidade de vida das famílias de baixa renda, predominantemente na faixa de até 3 salários mínimos, que residam em aglomerados subnormais - favelas, mocambos, palafitas e

22 Em matéria do jornal O POVO (2004b), percebemos que "a disputa pelo apoio de lideranças comunitárias fez os vereadores aliados ao prefeito entrarem em choque com três secretários executivos regionais. Os vereadores acusam os titulares da SER's, que são pré-candidatos à Câmara, de avançar sobre seus territórios". 
cortiços, entre outras - localizados em regiões metropolitanas, aglomerações urbanas e capitais de estados e fortalecer as condições administrativas e institucionais dos municípios para dotá-los de maior capacidade de atuação no controle e recuperação desses núcleos e na adoção de medidas para evitar novas ocorrências (BRASIL, s/d, p. 2).

A aplicação dos recursos se realizava por meio de dois subprogramas: Urbanização de Assentamentos Subnormais (UAS), que tratava da implantação e execução de projetos integrados para a urbanização de assentamentos precários, e Desenvolvimento Institucional (DI), que objetivava capacitar as prefeituras nos aspectos relativos à gestão de uma política habitacional, bem como desenvolver ações de capacitação e estudos setoriais (BRASIL, s/d, p. 14).

O arranjo institucional definido pelo PHBB estabelecia como agente gestor a Secretária de Política Urbana (SEPUR) ${ }^{23}$, a CEF como agente operador e financeiro e aos estados e municípios cabia a implementação das ações. Além disso, os beneficiários deveriam ser representados por suas organizações comunitárias, através do que o programa chamou de Entidade Representativa dos Beneficiários (ER). Em tese, as ER's deveriam "participar efetivamente em todas as etapas do processo, desde a definição e aprovação do projeto integrado até a sua avaliação final” (BRASIL, s/d, p. 7), participação essa que não se efetivou na prática.

\subsubsection{A HABITAFOR na gestão Juraci Magalhães (2003 - 2004)}

A Prefeitura Municipal de Fortaleza (PMF) assinou o convênio com a CEF e o BID, pelo PHBB, em 199924. Como o quinto município em população do Brasil, a existência de centenas de favelas e a inexistência de um órgão que de fato pensasse a política habitacional, Fortaleza se credenciou como um dos municípios a receber maior volume de recursos (PEQUENO, 2011).

\footnotetext{
23 Em 2000, a Secretaria Especial de Desenvolvimento Urbano da Presidência da República SEDU/PR assume o papel de agente gestor do PHBB e, em 2003, essa atribuição é transferida para o Ministério das Cidades.

${ }^{24}$ A lei municipal de $n^{\circ}$ 8.259, de 28 de abril de 1999, autorizou o Município de Fortaleza a celebrar o convênio para a implantação do PHBB (FORTALEZA, 1999a).
} 
Para os municípios iniciarem a implementação do PHBB e acessarem os recursos disponíveis era necessário tomar duas providências, ou requisitos básicos: constituir uma Unidade Executora Municipal - UEM, responsável pela elaboração, implementação e gerenciamento dos projetos e ações dos Subprogramas de DI e UAS (BRASIL, 2000a); e elaborar o Plano Estratégico Municipal de Assentamentos Subnormais (PEMAS), através da contratação de um consultor reconhecido por sua experiência na área, que deveria conter um diagnóstico inicial do problema habitacional do município. A aprovação de uma versão preliminar do PEMAS já era suficiente para a liberação de outros contratos de DI (BRASIL, 2000b).

Conforme Orientação Operacional da SEDU/PR, a UEM poderia estar inserida em qualquer órgão da administração municipal, com uma preferência por órgãos nas áreas responsáveis ou pelo planejamento urbano, ou pela política habitacional (BRASIL, 2000c). Legalmente, a Secretaria Municipal de Desenvolvimento Econômico $(\mathrm{SMDE})^{25}$, através de uma Coordenadoria de Habitação, é quem deveria desenvolver as atividades de coordenação e planejamento da política habitacional do município (FORTALEZA, 2001). Contudo, o órgão escolhido para assumir as funções de UEM foi a COMHAB, que possuía um caráter mais executivo, embora fosse o único no município que tratava com a questão de urbanização de favelas por ser o responsável pela execução do ProRenda Urbano, como já vimos. Os demais tratavam apenas da questão da provisão habitacional. Deste modo, a COMHAB foi instituída como UEM ${ }^{26}$ e assumiu a responsabilidade pela elaboração do PEMAS, bem como as demais ações de DI (FORTALEZA, 2003a).

Ao invés de realizar um diagnóstico abrangente sobre a questão habitacional em Fortaleza, a equipe de elaboração do PEMAS aproveitou-se de levantamentos, como

\footnotetext{
${ }^{25}$ A mesma lei que criou a SMDE, lei o 8.282, de 30 de junho de 1999, também foi responsável pela extinção do Instituto de Planejamento do Município (IPLAM), que era vinculado à Secretaria de Ação Governamental (SAG) (FORTALEZA, 1999b). De modo que Fortaleza passou mais de uma década sem um órgão ou instituição que tratasse especificamente do planejamento urbano. Por sua vez, o decreto municipal no 10.552, de 14 de julho de 1999, que dispôs sobre as finalidades, competências e estrutura administrativa da SMDE, estabeleceu dentre suas competências "promover estudos e pesquisas sobre as demandas habitacionais, bem como planejar, coordenar, executar e avaliar programas de habitação e moradia" atividades essas que deveriam ser realizadas por uma Coordenadoria de Habitação que não chegou a ser implementada na prática. (FORTALEZA, 1999c).

26 O decreto $\mathrm{n}^{\circ}$ 10.661, de 20 de dezembro de 1999, atribuiu à COMHAB a função de UEM, tornandoa diretamente responsável por implantar os projetos e ações financiados com recursos do Programa Habitar Brasil/BID (FORTALEZA, 1999d).
} 
o Dossiê das Áreas de Risco da Zona Periférica de Fortaleza e o Manual da Miséria em Áreas de Risco, realizados por instituições do terceiro setor, como o Centro de Defesa e Promoção dos Direitos Humanos da Arquidiocese de Fortaleza (CDPDH), no âmbito do Fórum das Áreas de Risco ${ }^{27}$. Desta forma, o PEMAS apresentou um mapeamento de $\mathbf{7 9}$ áreas de risco existentes no município, bem como uma hierarquização destas (Mapa 10 e Quadro 3). Também foi assinalada a existência de 613 favelas em Fortaleza, sem um mapeamento de suas localizações, com uma população da ordem de 759.000 pessoas, ocupando $32,62 \%$ dos domicílios do município, quase o dobro do que havia sido registrado em 1991 pela Secretaria de Trabalho e Ação Social do Estado do Ceará, que apontava a existência de 355 favelas (FORTALEZA, 2001).

Mapa 10 - Mapa das áreas de risco apresentado pelo PEMAS

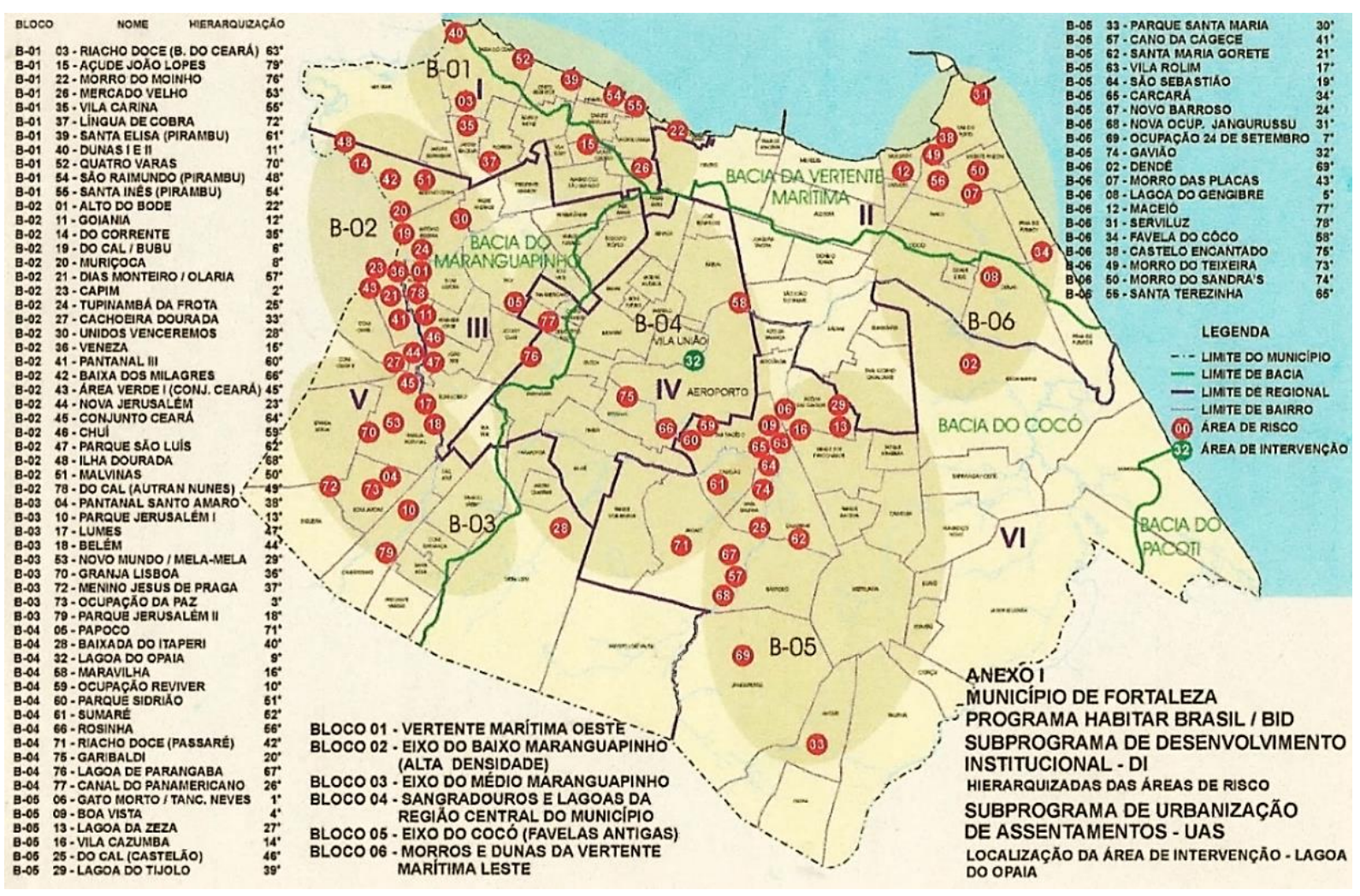

Fonte: PEMAS (FORTALEZA, 2001)

27 Conforme Olinda Marques, ex-diretora do CEARAH Periferia (CP) e atual secretária executiva da HABITAFOR, o Fórum das Áreas de Risco surgiu da necessidade de se articular as diversas entidades que monitoravam as áreas de risco em Fortaleza, como o próprio $\mathrm{CP}$, a Federação de Bairros e Favelas, a Cáritas Arquidiocesana, a Defesa Civil do Estado, a Cruz Vermelha, os Bombeiros, a Universidade Federal do Ceará, entre outras. A ideia era cruzar os levantamentos realizados por cada uma dessas entidades e produzir um relatório a fim denunciar a situação precária dessas áreas e com isso pressionar a prefeitura, então comandada por Juraci Magalhães, a agir (MARQUES, 2016). 
Quadro 3 - Hierarquização das Áreas de Risco do PEMAS

\begin{tabular}{|c|c|c|c|}
\hline BLOCO & № & NOME & HIERARQUIZAÇÃO \\
\hline B-05 & 6 & Gato Morto / Tancredo Neves & 1 \\
\hline B-02 & 23 & Capim & 2 \\
\hline B-03 & 73 & Ocupação da Paz & 3 \\
\hline B-05 & 9 & Boa Vista & 4 \\
\hline B-06 & 8 & Lagoa do Gengibre & 5 \\
\hline B-02 & 19 & Do Cal / Bubu & 6 \\
\hline B-05 & 69 & Ocupação 24 de Setembro & 7 \\
\hline B-02 & 20 & Muriçoca & 8 \\
\hline B-04 & 32 & Lagoa do Opaia & 9 \\
\hline B-04 & 59 & Ocupação Reviver & 10 \\
\hline B-01 & 40 & Dunas I e II & 11 \\
\hline B-02 & 11 & Goiania & 12 \\
\hline B-03 & 10 & Parque Jerusalém & 13 \\
\hline B-05 & 16 & Vila Cazumba & 14 \\
\hline B-02 & 36 & Veneza & 15 \\
\hline B-04 & 58 & Maravilha & 16 \\
\hline B-05 & 63 & Vila Rolim & 17 \\
\hline B-03 & 79 & Parque Jerusalém II & 18 \\
\hline B-05 & 64 & São Sebastião & 19 \\
\hline B-04 & 75 & Garibaldi & 20 \\
\hline B-05 & 62 & Santa Maria Gorete & 21 \\
\hline B-02 & 1 & Alto do Bode & 22 \\
\hline B-02 & 44 & Nova Jerusalém & 23 \\
\hline B-05 & 67 & Novo Barroso & 24 \\
\hline B-02 & 24 & Tupinambá da Frota & 25 \\
\hline B-04 & 77 & Canal do Panamericano & 26 \\
\hline B-05 & 13 & Lagoa da Zeza & 27 \\
\hline B-02 & 30 & Unidos Venceremos & 28 \\
\hline B-03 & 53 & Novo Mundo / Mela-mela & 29 \\
\hline B-05 & 33 & Parque Santa Maria & 30 \\
\hline B-05 & 68 & Nova Ocupação Jangurussu & 31 \\
\hline B-05 & 74 & Gavião & 32 \\
\hline B-02 & 27 & Cachoeira Dourada & 33 \\
\hline B-05 & 65 & Carcará & 34 \\
\hline B-02 & 14 & Do Corrente & 35 \\
\hline B-03 & 70 & Granja Lisboa & 36 \\
\hline B-03 & 72 & Menino Jesus de Praga & 37 \\
\hline B-03 & 4 & Pantanal Santo Amaro & 38 \\
\hline B-05 & 29 & Lagoa do Tijolo & 39 \\
\hline B-04 & 28 & Baixada do Itaperi & 40 \\
\hline B-05 & 57 & Cano da CAGECE & 41 \\
\hline B-04 & 71 & Riacho Doce (Passaré) & 42 \\
\hline B-06 & 7 & Morro das Placas & 43 \\
\hline B-03 & 18 & Belém & 44 \\
\hline B-02 & 43 & Área Verde I (Conjunto Ceará) & 45 \\
\hline B-05 & $|25|$ & Do Cal (Castelão) & 46 \\
\hline
\end{tabular}




\begin{tabular}{l|r|l|l} 
B-03 & 17 & Lumes & 47 \\
B-01 & 54 & São Raimundo (Pirambu) & 48 \\
B-02 & 78 & Do Cal (Autran Nunes) & 49 \\
B-02 & 51 & Malvinas & 50 \\
B-04 & 60 & Parque Sidrião & 51 \\
B-04 & 61 & Sumaré & 52 \\
B-01 & 26 & Mercado Velho & 53 \\
B-01 & 55 & Santa Inês (Pirambu) & 54 \\
B-01 & 35 & Vila Carina & 55 \\
B-04 & 66 & Rosinha & 56 \\
B-02 & 21 & Dias Monteiro / Olaria & 57 \\
B-06 & 34 & Favela do Côco & 58 \\
B-02 & 46 & Chuí & 59 \\
B-02 & 41 & Pantanal III & 60 \\
B-01 & 39 & Santa Elisa (Pirambu) & 61 \\
B-02 & 47 & Parque São Luís & 62 \\
B-01 & 3 & Riacho Doce (Barra do Ceará \\
B-02 & 45 & Conjunto Ceará & 63 \\
B-06 & 56 & Santa Terezinha & 64 \\
B-02 & 42 & Baixa dos Milagres & 65 \\
B-04 & 76 & Lagoa da Parangaba & 66 \\
B-02 & 48 & llha Dourada & 67 \\
B-06 & 2 & Dendê & 68 \\
B-01 & 52 & Quatro Varas \\
B-04 & 5 & Papoco \\
B-01 & 37 & Língua de Cobra \\
B-06 & 49 & Morro do Teixeira & 69 \\
B-06 & 50 & Morro do Sandra's & 70 \\
B-06 & 38 & Castelo Encantado & 71 \\
B-01 & 22 & Morro do Moinho & 72 \\
B-06 & 12 & Maceió & 73 \\
B-06 & 31 & Serviluz & 74 \\
B-01 & 15 & Açude João Lopes & 76 \\
\hline & & 77 \\
\hline & & 78 \\
& & 79 \\
\hline
\end{tabular}

Notas:

B-01 Vertente Marítima Oeste

B-02 Eixo do Baixo Maranguapinho (alta densidade)

B-03 Eixo do Médio Maranguapinho

B-04 Sangradouros e Lagoas da Região Central do Município

B-05 Eixo do Cocó (Favelas Antigas)

B-06 Morros e Dunas da Vertente Marítima Leste

Fonte: PEMAS (FORTALEZA, 2001), elaboração do autor

Quanto ao déficit habitacional no município, o PEMAS apresentou o número de 145.000 famílias com demanda por moradia, dentre as quais 101.500 teriam rendimentos de até três salários mínimos. No entanto, o conceito adotado pelo estudo não diferenciou o déficit quantitativo do qualitativo, juntando as componentes do déficit (coabitação familiar, precariedade da habitação e ônus excessivo com o aluguel) com 
componentes de inadequação domiciliar (inadequação da infraestrutura de saneamento e o adensamento excessivo no domicílio) ${ }^{28}$.

No que se refere à situação institucional, o PEMAS apontou que "no município de Fortaleza, as atribuições de definição, coordenação, planejamento, implantação, avaliação e controle da política habitacional, estão diluídas em vários órgãos, havendo inclusive superposição de funções" (FORTALEZA, 2001, p. 8). Não havia uma política habitacional definida de fato. Pequeno (2008) descreve esta situação institucional:

Em Fortaleza, a situação institucional se mantinha precária e
desgovernada. Com açôes em diversas secretarias, a questão da
moradia era tratada de forma incipiente, fragmentada e acéfala, como
o próprio planejamento urbano, ficando estas temáticas sempre a
mercê de consultorias e terceirizações que em nada contribuíam para
o desenvolvimento institucional. Conforme o PEMAS, os seguintes órgãos estavam envolvidos com a questão da habitação e planejamento urbano em Fortaleza (FORTALEZA, 2001):

- A Secretaria de Ação Governamental (SAG) coordenava e executava o programa de melhorias habitacionais Morar Melhor, o que constituía um desvio de suas finalidades, já que seu objetivo era orientar e articular as ações governamentais;

- A Secretaria Municipal de Desenvolvimento Social (SMDS) era responsável pelo Fundo Municipal de Desenvolvimento Social (FMDS) e pela coordenação e execução do trabalho social nos programas habitacionais, porém, na prática, o órgão executor de cada programa é quem o realizava;

- A Secretaria Municipal de Desenvolvimento Territorial e Meio Ambiente (SMDT) tinha como responsabilidades a Comissão Normativa de Desenvolvimento Urbano (CNDU), a Comissão Permanente de Avaliação do Plano Diretor (CPPD), o Fundo Municipal de Desenvolvimento Urbano (FMDU), coordenou inicialmente o Pró-Moradia até ser transformada em SEINF, mantendo esta atribuição, e também planejava e executava obras viárias e de infraestrutura, coordenando o programa Pró-Saneamento no município;

${ }^{28}$ A diferenciação entre déficit quantitativo e qualitativo faz parte da metodologia concebida pela Fundação João Pinheiro e adotada pelo Ministério das Cidades / Governo Federal. 
- A Secretaria Municipal de Desenvolvimento Econômico (SMDE), além de executar ações estratégias para o desenvolvimento econômico do município, deveria desempenhar a função de planejamento da política habitacional, mas, como sua Coordenadoria de Habitação nunca foi de fato implementada, acabou por não desempenhar tal atribuição;

- As Secretarias Executivas Regionais (SER), em número de seis, possuíam como atribuição a identificação de famílias a serem atendidas pelos programas de habitação e 0 atendimento de forma emergencial àquelas atingidas por calamidades e acabaram assumindo a atribuição de execução das obras do Pró-Moradia, logrando ganhos políticos para seus secretários;

- A Comissão de Implantação de Projetos Habitacionais de Interesse Social e Infraestrutura Urbana (COMHAB) era responsável pela execução dos programas Mutirões Habitacionais, ProRenda Urbano e assumiu a condição de UEM para a implantação do PHBB, além de ter a atribuição de promover processos de regularização fundiária.

Além dos órgãos mencionados, havia o Conselho Municipal de Habitação Popular (COMHAP) ${ }^{29}$, criado em 1996 como um órgão consultivo e de assessoramento ao prefeito, que tinha como presidente o coordenador da COMHAB e possuía a função de propor normas e diretrizes para a política habitacional, bem como de participar do gerenciamento do Fundo de Terras (FORTALEZA, 1996). Mesmo após duas reformulações em gestões posteriores, o COMHAP não conseguiu, de fato, atuar sobre a política habitacional de modo a orientar, monitorar e avaliar as ações do poder

29 O COMHAP foi criado pela lei $\mathrm{n}^{\circ}$ 7.966, de dezembro de 1996, que o definiu como um "órgão consultivo e de assessoramento do Chefe do Poder Executivo, no estabelecimento da política de habitação" (FORTALEZA, 1996). Em 1997, a lei no 8.050, de 24 de julho, alterou sua composição. Em 1998, o COMHAP foi novamente reestruturado pela lei no 8.214 , de 04 de dezembro de 1998. Na gestão Luizianne Lins (2005 - 2012), o COMHAP foi mais uma vez reestruturado através da lei oㅜ 9.132 , de 18 de dezembro de 2006. Pela primeira vez o COMHAP teve uma composição paritária entre entidades da sociedade civil e do poder público e adquiriu um caráter deliberativo, devendo decidir sobre: a aplicação dos recursos oriundos do Fundo Nacional de Habitação de Interesse Social (FNHIS), a proposta orçamentária anual da HABITAFOR, as ações a serem financiadas com recursos do Fundo Municipal de Habitação (FMP) (FORTALEZA, 2006). Contudo, mesmo com a mudança de composição, o caráter deliberativo e a ampliação de suas atribuições, o COMHAP não recebeu a devida importância por parte das gestões municipais, passando cerca de sete anos sem funcionar, entre 2009 e 2016. Para se ter uma noção do permanente desinteresse, os atuais conselheiros esperaram sete meses entre sua eleição em janeiro de 2016 e a publicação de sua nomeação pela prefeitura em agosto de 2016, através do decreto № 13.876 (FORTALEZA, 2016). 
público. Podemos ter uma ideia da fragmentação e desarticulação do setor habitacional no município através do Gráfico 1.

Gráfico 1 - Atribuições dos órgãos municipais na área de habitação

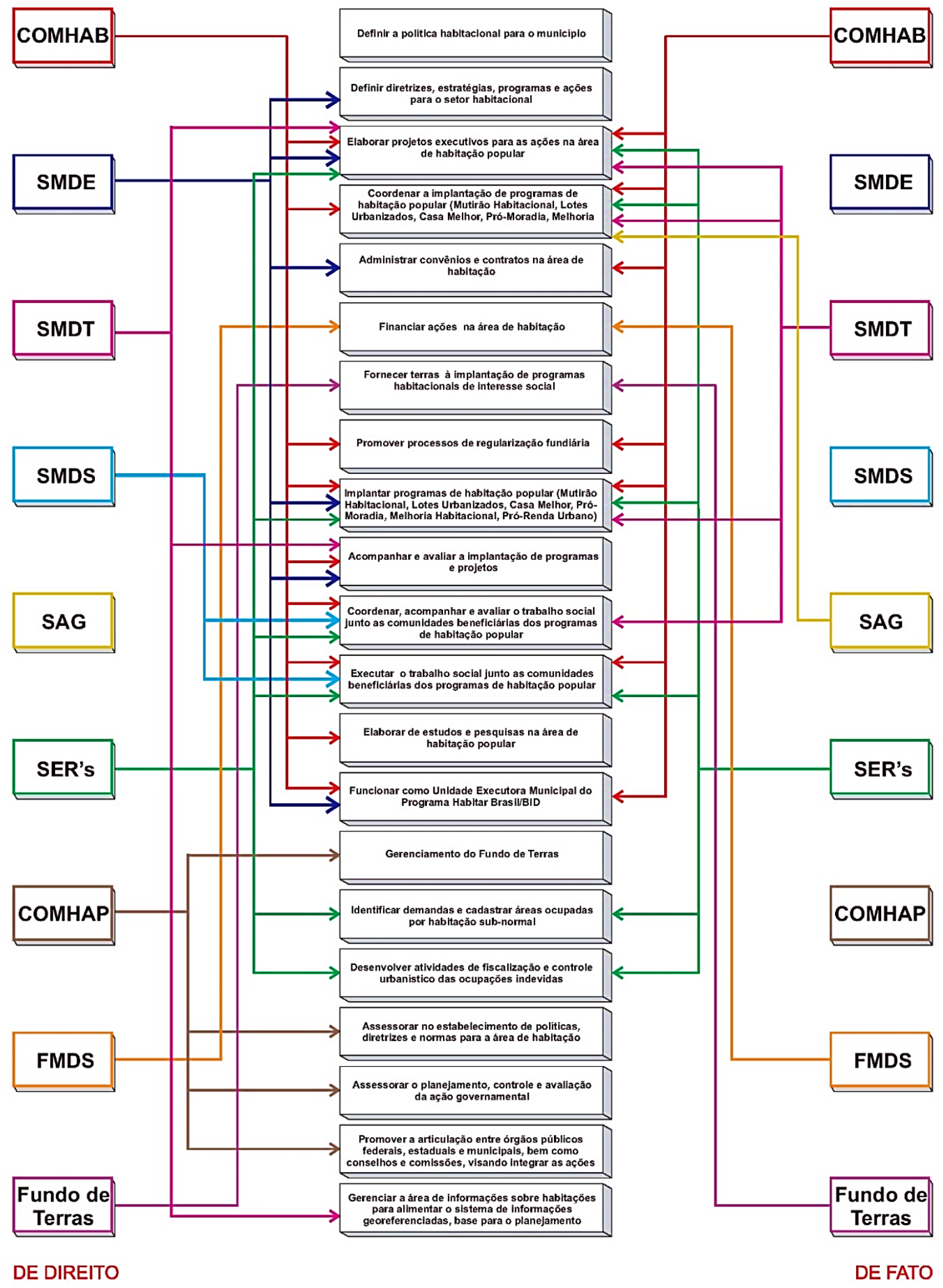

Fonte: PEMAS (FORTALEZA, 2001) 
No relatório do PEMAS foram destacados diversos problemas: a inexistência de uma política habitacional; a inexistência de uma clara definição quanto aos programas a serem implementados pelo município; a dispersão das responsabilidades e atribuições relativas à habitação em vários órgãos, havendo inclusive sobreposição de funções entre eles; a desatualização dos dados referentes à situação dos assentamentos precários, como cadastros de favelas e de áreas de risco; a inexistência de um cadastro de loteamentos irregulares e clandestinos; a inadequação da legislação para projetos de habitação popular; e a inexistência de um cadastro de demandas habitacionais e de pessoas já beneficiadas pelos programas (FORTALEZA, 2001). Para enfrentá-los, foi elaborada uma matriz de ações a serem desenvolvidas pela COMHAB, que buscavam estruturar o setor habitacional no município nos âmbitos das políticas e programas, do planejamento e gestão e da regulação urbanística (Quadro 4).

Quadro 4 - Componentes da Matriz do PEMAS de Fortaleza

\begin{tabular}{|c|c|c|}
\hline $\begin{array}{l}\text { POLÍTICAS E } \\
\text { PROGRAMAS }\end{array}$ & PLANEJAMENTO E GESTÃO & $\begin{array}{l}\text { REGULAÇÃO } \\
\text { URBANISTICA }\end{array}$ \\
\hline \multirow{2}{*}{$\begin{array}{l}\text { Política Habitacional } \\
\text { de Interesse Social } \\
\text { (PHIS) }\end{array}$} & Revisão e atualização do PEMAS & \multirow{2}{*}{$\begin{array}{l}\text { Participação da iniciativa } \\
\text { privada na produção de } \\
\text { habitação de interesse } \\
\text { social }\end{array}$} \\
\hline & $\begin{array}{l}\text { Estrutura administrativa da Prefeitura no setor } \\
\text { habitacional }\end{array}$ & \\
\hline $\begin{array}{l}\text { Regularização } \\
\text { fundiária, urbanística e } \\
\text { edilícia }\end{array}$ & $\begin{array}{l}\text { Cadastro dos assentamentos subnormais } \\
\text { (Tipologia I - Favelas e Cortiços) }\end{array}$ & $\begin{array}{l}\text { Lei de Uso e Ocupação } \\
\text { do Solo }\end{array}$ \\
\hline \multirow[t]{9}{*}{$\begin{array}{l}\text { Programas de } \\
\text { Intervenção }\end{array}$} & $\begin{array}{l}\text { Cadastro dos assentamentos subnormais } \\
\text { (Tipologia I - Loteamentos Irregulares e } \\
\text { Clandestinos) }\end{array}$ & Código de Obras \\
\hline & Financiamento da produção habitacional & $\begin{array}{l}\text { Lei de Parcelamento do } \\
\text { Solo }\end{array}$ \\
\hline & $\begin{array}{l}\text { Sistema de controle dos beneficiários dos } \\
\text { programas habitacionais no município }\end{array}$ & $\begin{array}{l}\text { Lei Orgânica do } \\
\text { Município }\end{array}$ \\
\hline & $\begin{array}{l}\text { Procedimentos para aprovação de loteamentos } \\
\text { e obras em assentamentos subnormais }\end{array}$ & \\
\hline & $\begin{array}{l}\text { Mecanismos de integração inter-setorial e de } \\
\text { articulação interinstitucional }\end{array}$ & \\
\hline & Fiscalização e controle das ocupações & \\
\hline & Controle Urbanístico & \\
\hline & $\begin{array}{l}\text { Programa de Capacitação dos setores } \\
\text { habitacional / urbano da Prefeitura de Fortaleza }\end{array}$ & \\
\hline & Banco de Terras & \\
\hline
\end{tabular}

Fonte: PEMAS (FORTALEZA, 2001) 
A Prefeitura optou por elaborar Termos de Referências (TR) para a contratação de empresas para desenvolver as ações, seguindo a lógica neoliberal de utilização de consultorias e terceirização dos serviços, ao invés da estruturação, dentro da administração municipal, de uma equipe técnica própria capacitada para desenvolver e implementar as ações, de modo a permitir uma continuidade da política. Para Pequeno (2011), a PMF não soube aproveitar o que o PHBB oferecia, assim como a COMHAB nunca se demonstrou capaz e interessada em assumir realmente o problema.

Passou 2000, 2001, 2002 que começou a sair alguma coisa. Os Termos de Referência, muitos deles nunca foram elaborados. Só vieram a ser elaborados quando a Olinda assumiu a HABITAFOR. Todo esse período, o dinheiro acabou sendo perdido por Fortaleza não ter se organizado. O pouco que ela organizou, acabou também terceirizando os trabalhos. Por exemplo, a política de habitação foi terceirizada para o CETREDE (PEQUENO, 2011).

Como mencionado por Pequeno, o Centro de Treinamento e Desenvolvimento (CETREDE), da Universidade Federal do Ceará (UFC), foi contratado ${ }^{30}$ para elaborar a Política Habitacional de Interesse Social (PHIS) de Fortaleza. Para isso, foi desenvolvido um novo diagnóstico da situação habitacional no município pela equipe do CETREDE. Na realidade, o trabalho apresentado foi uma espécie de revisão um pouco mais aprofundada do diagnóstico do PEMAS, a fim de subsidiar as ações de DI, bem como a elaboração da PHIS (FORTALEZA, 2003a).

No Diagnóstico da PHIS houve uma separação entre as necessidades de novas moradias, que segundo o estudo somavam mais de 45 mil unidades, de realização de melhorias habitacionais, estimadas em mais de 40 mil unidades, e de implantação de infraestrutura básica (predominantemente saneamento), que abrangiam mais de 158 mil unidades, ou cerca de 30\% dos domicílios urbanos de Fortaleza (FORTALEZA, 2003a).

Novamente a PMF se utilizou de pesquisas realizadas por ONG's e Movimentos Sociais entre 1996 e 2002 (Mapa 11), sem investir grandes esforços no detalhamento

\footnotetext{
30 Assinado no dia 15 de julho de 2002, o contrato entre a Prefeitura e o CETREDE tinha como objeto a "contratação de pessoa jurídica para prestar serviços de consultoria para a elaboração da Política Habitacional de Interesse Social para o Município de Fortaleza, conforme definições constantes do Edital Tomada de Preços $n^{\circ}$ 001/2002 e no Termo de Referência (anexo l)", com um prazo de oito meses e valor de $\mathrm{R} \$ 124.947,00$ (FORTALEZA, 2002, p. 8).
} 
e atualização das informações. Também foi feito um levantamento de dados existentes em secretarias e órgãos do município e do governo estadual. As áreas de risco passaram de 79 (PEMAS) para 112, conforme um levantamento realizado pela Defesa Civil do Município, que somadas atingiam um total de 17.602 famílias (FORTALEZA, 2003a). É preciso ressaltar que tais levantamentos se baseavam no registro de ocorrências de calamidades e não na realização de um diagnóstico técnico que avaliasse a existência de um risco iminente à população, como inundações, deslizamentos, ou outros, o que implicava em um subdimensionamento do problema.

\section{Mapa 11 - Levantamento das Áreas de Risco pelo CDPDH}

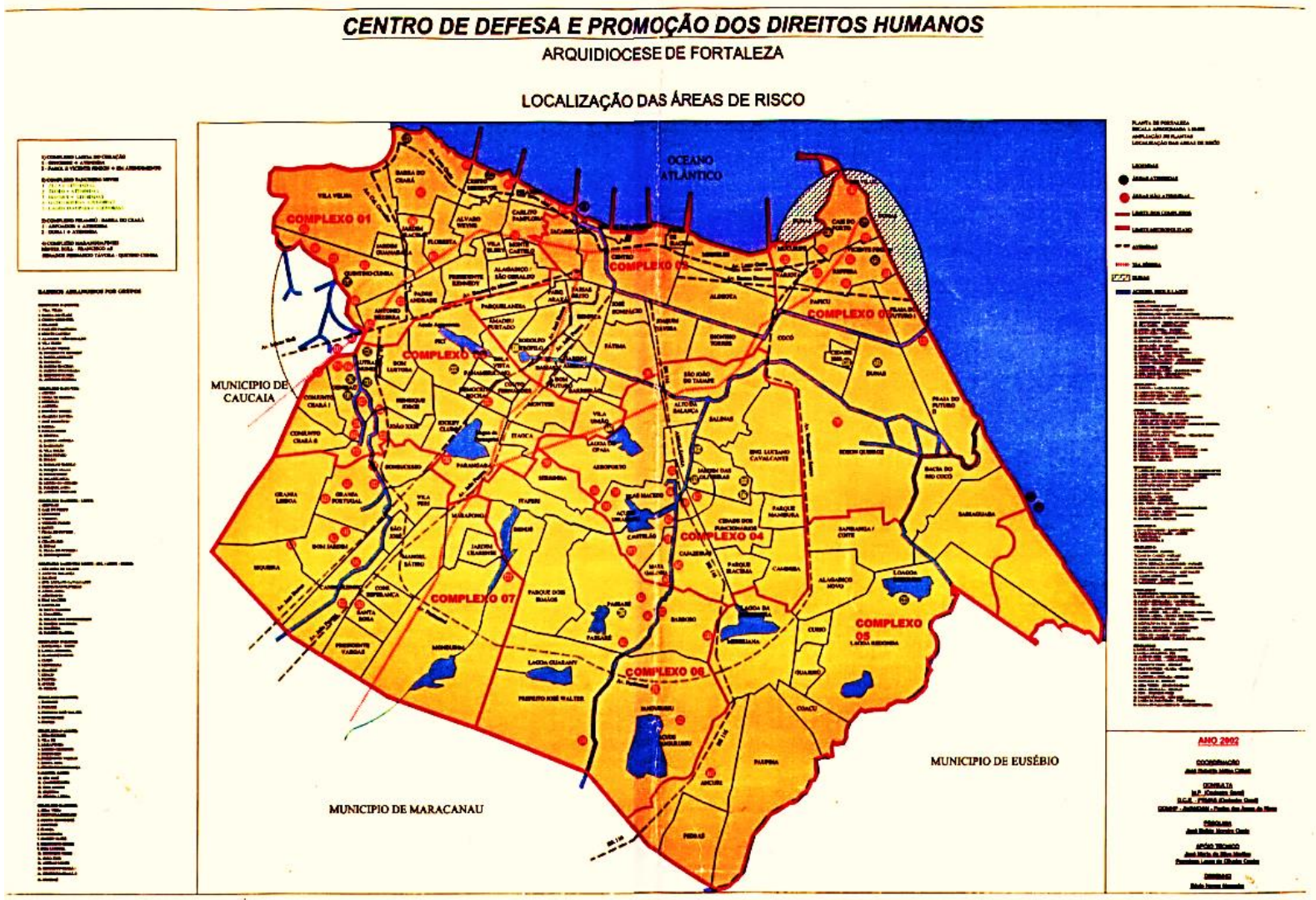

Fonte: Diagnóstico da PHIS (FORTALEZA, 2003a)

Estudos de caso de áreas subnormais foram realizados como forma de "suprir uma deficiência técnica de falta de estudos mais elaborados sobre a situação destas áreas na cidade" (FORTALEZA, 2003a, p. 71). Os assentamentos selecionados foram: Cal Bubu (zona oeste), Santa Eliza (litoral oeste), Morro das Placas (zona leste), Lagoa do Opaia (zona sudoeste) e Curió (zona sul), numa tentativa vã de se representar o universo dos assentamentos subnormais do município, enquadrados em áreas de risco, favelas, ou conjuntos habitacionais. Podemos observar no Mapa 12 a localização das áreas selecionadas como estudos de caso. 


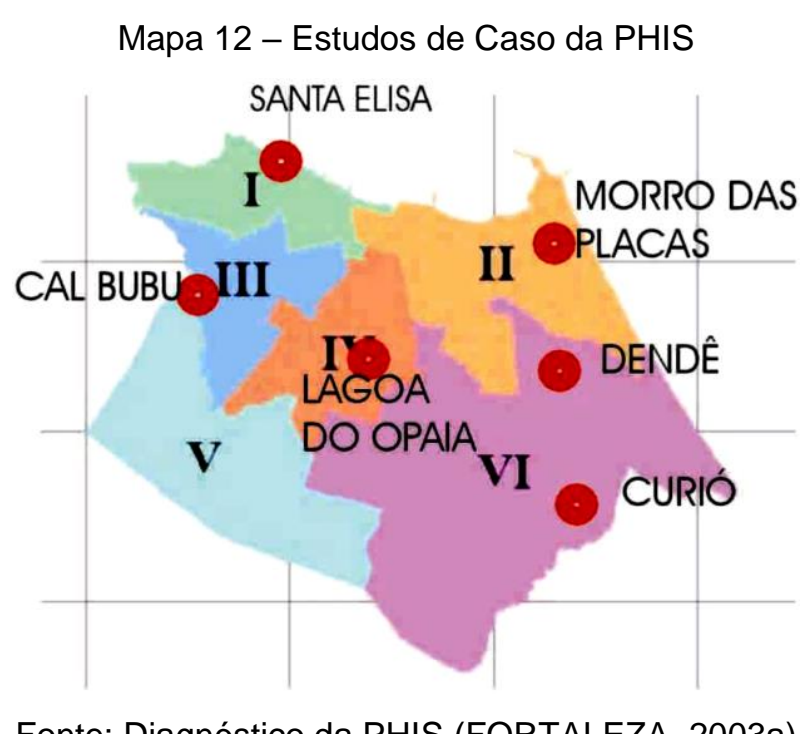

Fonte: Diagnóstico da PHIS (FORTALEZA, 2003a)

A lógica da COMHAB era garantir a verba para executar e inaugurar obras, assim, as licitações que foram realizadas para DI tinham como objetivo apenas a liberação de verba para as obras (RODRIGUES, 2016). Portanto, mesmo sem ter elaborado todos os componentes do PEMAS, a prefeitura conseguiu obter recursos para a realização de projetos e obras de urbanização.

A Lagoa do Opaia foi escolhida como o projeto piloto que serviria de aprendizado para a equipe do município sobre como proceder. Contudo, mesmo com as obras na Lagoa do Opaia por concluir, a COMHAB garantiu recursos para mais uma obra (PEQUENO, 2008). Assim, foi escolhida a área da Favela Maravilha, situada próxima da BR-116, principal rodovia de acesso à Fortaleza, à margem do canal do Tauape e cortada pelo antigo ramal Parangaba-Mucuripe da linha férrea ${ }^{31}$ (Mapa 13). Ressaltamos que as áreas selecionadas se classificavam respectivamente em nono e em décimo sexto lugares na hierarquização de áreas de risco estabelecida no PEMAS (Quadro 3).

Percebe-se que a escolha das áreas de intervenção se relacionava mais a uma política de construção de uma nova imagem para Fortaleza do que às condições de

\footnotetext{
${ }^{31}$ Atualmente esse ramal ferroviário está sendo transformado pelo Governo do Estado do Ceará em uma linha de Veículo Leve sobre Trilhos (VLT). A implantação do VLT, uma obra de mobilidade eleita como prioritária para a Copa de 2014 e ainda hoje não concluída, tem causado enormes conflitos com assentamentos precários instalados às margens do ramal ferroviário. Por sua vez, o Governo do Estado tem utilizado unidades habitacionais produzidas através do Programa Minha Casa Minha Vida como moeda de barganha nas negociações com as famílias para removê-las de suas moradias, em especial - Residencial Cidade Jardim, localizado na borda periférica sul de Fortaleza. Para mais informações sobre o VLT ver Gois (2013) e lacovini (2015).
} 
precariedade dos assentamentos, dentro de um contexto de competição entre cidades para a atração do Capital, especialmente através do turismo.

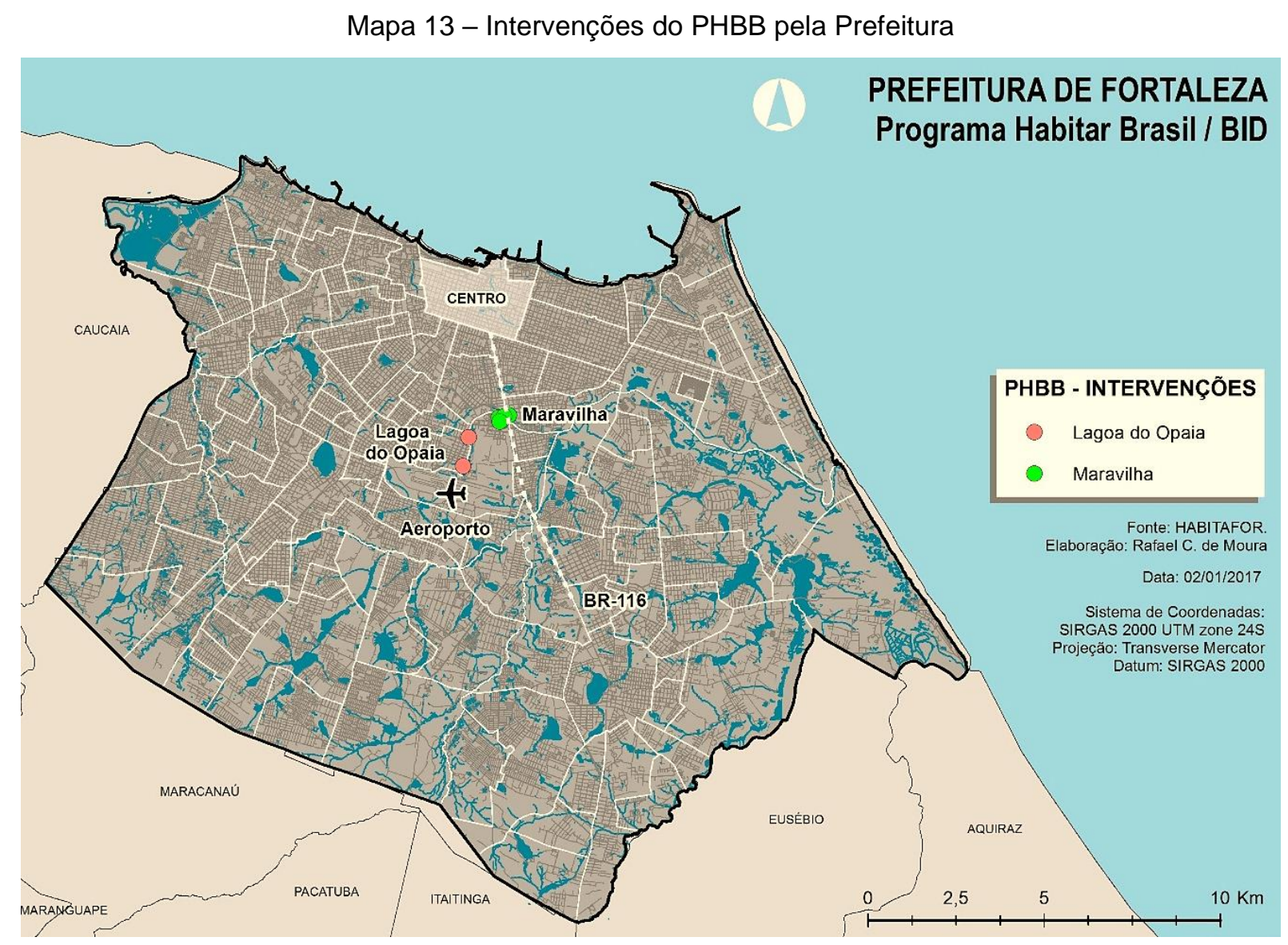

Fonte: HABITAFOR, elaboração do autor

O que valia era a lógica de que era uma favela do lado do aeroporto. Então, tinha que resolver aquele problema, você não podia chegar no aeroporto dentro duma favela, então foi a área escolhida. Do mesmo jeito que a segunda área foi o Maravilha, que é a entrada da cidade. Você não pode entrar na cidade vendo uma favela. Então, isso fez que essa lógica, que vem desde o programa de desfavelamento, de retirar as áreas de favelas dos pontos, que é o que gerou o Arraial Moura Brasil, que foi lá pro Palmeiras, que se mantém essa lógica (PEQUENO, 2011).

Reiterando o relatório do PEMAS, o diagnóstico da PHIS apontou um "setor habitacional fragmentado internamente, sem dispor de um órgão central que desenvolva políticas, coordene programas e projetos habitacionais e ações complementares" (FORTALEZA, 2003a, p. 151). As ações se davam de forma desarticulada, sem uma definição de prioridades e metas. Não havia uma articulação entre as políticas setoriais municipais, assim como entre a política habitacional do município e as esferas estadual e federal. 
No que se refere aos recursos humanos para o setor habitacional, o quadro de pessoal da PMF era incompatível em termos quantitativo e qualitativo com as demandas, em função das necessidades habitacionais. A COMHAB, que constituiu a UEM no PHBB, possuía apenas 31 funcionários (Quadro 5). Quando somados os funcionários dos demais órgãos que tinham uma interface com a questão habitacional em Fortaleza, como a SEINF e as SER's, chegamos ao número de 122 profissionais (FORTALEZA, 2003a), lembrando que esses órgãos possuíam outras atribuições além da habitação. Na gestão seguinte, somente o quadro de funcionários da HABITAFOR superará este número.

Quadro 5 - Recursos humanos da COMHAB

\begin{tabular}{l|r|r|r|r}
\hline \multirow{2}{*}{ CARGO/FUNÇÃO } & \multicolumn{3}{|c|}{ SITUAÇÃO FUNCIONAL } & \multirow{2}{*}{ TOTAL } \\
\cline { 2 - 5 } & EFETIVO & COMISSIONADO & TERCEIRIZADO & \\
\hline Engenheiro Civil & 1 & 2 & 0 & 3 \\
Engenheiro Eletricista & 1 & 0 & 0 & 1 \\
Arquiteto & 1 & 0 & 0 & 1 \\
Assistente Social & 3 & 2 & 0 & 5 \\
Addvogado & 0 & 2 & 0 & 2 \\
Contador & 1 & 0 & 0 & 1 \\
Pessoal de Apoio & 12 & 2 & 0 & 14 \\
Estagiários & 0 & 0 & 0 & 4 \\
\hline \multicolumn{2}{|r|}{} & & TOTAL & 31 \\
\hline
\end{tabular}

Fonte: Diagnóstico da PHIS (FORTALEZA, 2003a, p. 167), adaptado pelo autor

Seguindo recomendações do Diagnóstico da PHIS, a COMHAB foi extinta. A fim de assumir suas funções como UEM, foi criada a Fundação de Desenvolvimento Habitacional de Fortaleza (HABITAFOR), ${ }^{32}$ vinculada à SEINF. "O processo foi mais lento em função da desatenção do prefeito Juraci Magalhães pra questão da habitação" (PEQUENO, 2011) e a HABITAFOR só foi instituída como forma de garantir o recurso paras as obras da Lagoa do Opaia e da Maravilha (RODRIGUES, 2016). Somente a partir de 2003, com o governo Lula, quando a gestão municipal vislumbra a possibilidade de tirar proveito da ampliação da oferta de recursos pelo governo

\footnotetext{
${ }^{32}$ A criação da HABITAFOR foi autorizada pela lei no 8.810 , de 30 de dezembro de 2003 (FORTALEZA, 2003b). Mesmo com a criação do órgão, matéria do jornal O Povo demonstra o desinteresse da gestão Juraci Magalhães com a questão habitacional: "Foi aprovada no dia 13/11, em primeira discussão na Câmara dos Vereadores, a lei no 345/2003, que cria a Fundação de Desenvolvimento Habitacional de Fortaleza (HABITAFOR). A forma como se deu o processo deixou claro que, na atual gestão do prefeito Juraci Magalhães, tão cedo não se resolve o problema do déficit habitacional. Os vereadores da bancada de sustentação do prefeito derrubaram todas as emendas que dariam caráter deliberativo e consultivo ao Conselho Municipal de Habitação (COMHAP)" (O POVO, 2003).
} 
federal para o setor habitacional, é que enfim se decide pela criação do órgão. Até mesmo a opção pelo formato de fundação se deveu à maior autonomia orçamentária que ele permitia (PEQUENO, 2011).

No apagar das luzes, o último ato da gestão Juraci Magalhães relativo à questão habitacional foi a aprovação da lei no 8.918 , que trata da PHIS de Fortaleza ${ }^{33}$. Quatro estratégias básicas constituíam a PHIS: I. Nossa morada - relacionada à questão da provisão habitacional; II. Morar Melhor - referente a ações de melhoria habitacional; III. Qualidade de Vida - ligada a intervenções de urbanização de assentamentos precários; e IV. Viver tranquilo - relativa à promoção de regularização fundiária em assentamentos precários. A lei da PHIS também instituiu o Fundo Municipal de Habitação (FMH), vinculado à HABITAFOR, que até hoje praticamente não tem sido utilizado como fonte de recursos para as ações habitacionais do município. Esse era basicamente o quadro institucional no setor habitacional legado à gestão seguinte, de Luizianne Lins, que abordaremos no próximo item.

\subsubsection{A HABITAFOR na gestão Luizianne Lins (2005 - 2012)}

Com a criação do Ministério das Cidades (MCidades), em 2003, no governo Lula (PT), a política habitacional no Brasil entrou em uma nova etapa, depois de um longo período de desarticulação após o fim do $\mathrm{BNH}$. O MCidades tornou-se "o órgão coordenador, gestor e formulador da Política Nacional de Desenvolvimento Urbano, que inclui a Política Nacional de Habitação (PNH), estabelecendo um novo modelo de organização institucional" (BONDUKI e ROSSETTO, 2008, p. 10).

Para Maricato (2006), a origem do MCidades decorre de um longo processo de luta pela Reforma Urbana que teve início ainda no regime militar, um movimento que logrou inserir a função social da propriedade e da cidade na Constituição Federal de 1988 (artigos 182 e 183), através de uma emenda de iniciativa popular, e, treze anos mais tarde, conquistou a aprovação do Estatuto da Cidade, lei oㅜ 10.257 de 2001, que estabeleceu uma nova base jurídica para a política urbana no Brasil. Além dos marcos legais, a autora destaca as experiências inovadoras de administrações municipais nos

${ }^{33}$ A lei da PHIS, de № 8.918 foi aprovada em 29 de dezembro de 2004. 
anos 1980, dentre as quais o orçamento participativo em Porto Alegre. No entanto, foi o Projeto Moradia ${ }^{34}$, divulgado em 2000, que formulou mais claramente a proposta para o Ministério das Cidades (MARICATO, 2006).

"O Projeto Moradia foi elaborado por 12 pessoas, entre especialistas e lideranças sociais, convidadas por Luiz Inácio Lula da Silva, por meio de uma ONG - Instituto Cidadania - por ele presidida. Após ouvir interlocutores de vários setores da sociedade, a equipe convidada formulou uma proposta - cuja redação final foi de Aloysio Biondi - da qual fazia parte a criação do Ministério das Cidades" (MARICATO, 2006, p. 215).

A estrutura formulada para o MCidades, com suas secretarias de Transporte e Mobilidade, Saneamento Ambiental e Habitação, buscou responder aos principais problemas urbanos encontrados nas cidades brasileiras. Além destas, uma quarta secretaria foi criada, a de Programas Urbanos, com o objetivo de enfrentar a questão fundiária e imobiliária, considerada central para 0 desenvolvimento urbano (MARICATO, 2006). O papel desta secretaria seria fornecer diretrizes e orientação para governos locais (estados e municípios) a fim de colocar em prática programas urbanos relacionados a questões específicas, como a regularização fundiária, a reabilitação de áreas urbanas centrais, a prevenção de riscos e o combate aos vazios urbanos (MARICATO, 2014).

Em relação à Habitação, esse tema passou a receber uma visão mais holística levando em conta não só a construção de novas moradias, mas também "issues", que, por vezes, são até mais importantes para enfrentar a questão do habitat, como regularização fundiária, saneamento, infraestrutura, transporte público, entre outros (AZEVEDO, 2007, p. 33).

Nos primeiros anos do governo Lula, observamos um processo de reestruturação do setor urbano/habitacional. Ainda em 2003, o Conselho das Cidades ${ }^{35}$ (ConCidades) foi criado como parte da estrutura básica do MCidades, na busca por uma gestão das cidades participativa e democrática. Em outubro de 2003 foi realizada a primeira Conferência Nacional das Cidades, na qual foram eleitos os primeiros conselheiros e

\footnotetext{
34 Para mais informações sobre o Projeto Moradia, ver (BONDUKI, 2009).

35 O ConCidades foi criado pela lei $n=10.683$, de 28 de maio de 2003 (BRASIL, 2003). O decreto no 5.031 , de 2 de abril de 2004, que dispôs sobre sua composição, estruturação, competências e funcionamento, conferiu-lhe uma natureza deliberativa e consultiva no que se refere à proposição de diretrizes para a formulação e implementação da política nacional de desenvolvimento urbano (BRASIL, 2004a).
} 
foram estabelecidos os princípios e diretrizes da nova PNDU, que assumiu para o desenvolvimento urbano uma noção de "melhoria das condições materiais e subjetivas de vida nas cidades, com diminuição da desigualdade social e garantia de sustentabilidade ambiental, social e econômica" (BRASIL, 2004b, p. 8).

Em 2004, foram lançadas as bases da nova Política Nacional de Habitação (PNH), "principal instrumento de orientação das estratégias e das ações a serem implementadas pelo governo federal" (BONDUKI e ROSSETTO, 2008, p. 11). A PNH trouxe como componentes principais: a integração urbana de assentamentos precários; a urbanização, regularização fundiária e inserção de assentamentos precários; a provisão habitacional; a integração da política de habitação à política de desenvolvimento urbano (BRASIL, 2004c). Os princípios da nova PNH alinharam-se ao Estatuto da Cidade, na busca: pelo direito à moradia digna, como vetor de inclusão social; pelo cumprimento da função social da propriedade urbana; pela visão da questão habitacional enquanto política de Estado; pela gestão democrática e participativa das cidades; e pela articulação da política habitacional com as demais políticas setoriais, nas três esferas de governo (BRASIL, 2004c).

Para implementar a nova $\mathrm{PNH}$, foi organizado o Sistema Nacional de Habitação (SNH), com base na integração das ações dos agentes, na utilização de recursos onerosos e não onerosos para a viabilização de programas e projetos, na adoção de regras únicas e na descentralização dos recursos e das ações (BONDUKI e ROSSETTO, 2008). O SNH foi dividido em dois subsistemas: o Subsistema Nacional de Habitação de Interesse Social (SNHIS) e o Subsistema de Habitação de Mercado (SHM).

O SNHIS foi instituído pela lei oㅜ 11.124, de 16 de junho de 2005, juntamente com o Fundo Nacional de Habitação de Interesse Social (FNHIS) ${ }^{36}$, com o objetivo principal de "viabilizar para a população de menor renda o acesso à terra urbanizada e à habitação digna e sustentável" (BRASIL, 2005). Já o SHM tem o foco no mercado privado a fim de ampliar a oferta de habitação para a classe média, de modo que esta

\footnotetext{
${ }^{36}$ A lei que instituiu o FNHIS, lei no 11.124/2005, "teve origem em um projeto de iniciativa popular, entregue ao Congresso Nacional em 1990, contendo mais de 1 milhão de assinaturas de eleitores" (MARICATO, 2014, p. 63).
} 
não dispute recursos federais com as faixas de baixa renda, como ocorre desde 0 período do BNH (AZEVEDO, 2007).

Deste modo, o paradigma sobre o qual se estruturou o novo SNH baseou-se em duas premissas: a ampliação do atendimento habitacional à classe média através do mercado privado de moradias, buscando a ampliação dos recursos financeiros e da segurança jurídica dos negócios; e a priorização nos investimentos do poder público no atendimento à população com renda até 5 salários mínimos, faixa na qual se concentra cerca de 92\% do déficit habitacional (AZEVEDO, 2007; MARICATO, 2006; BONDUKI, 2009; LEITÃO, 2009).

Apesar de voluntária, a adesão ao SNHIS foi definida como uma condição para o acesso por estados e municípios aos recursos e programas disponibilizados pelo MCidades. Através da assinatura do termo de adesão, os entes federativos se comprometem a criar em seus âmbitos de gestão uma estrutura voltada para a questão da habitação de interesse social composta por: um conselho (C) com representação da sociedade civil, um plano local $(P)$, e um fundo $(F)$. Essa estrutura, popularmente conhecida como "CPF", aponta para uma lógica de conjugação dos esforços entre os entes federativos, a partir de princípios e programas comuns, na busca pela resolução do problema da universalização da moradia digna (BONDUKI e ROSSETTO, 2008).

Conforme Bonduki e Rossetto (2008), para o funcionamento do SNHIS foi estabelecido um arranjo institucional que tem no MCidades seu agente gestor responsável pela definição das diretrizes, prioridades, estratégias e instrumentos da PNH. Ao Conselho Gestor do FNHIS (CGFNHIS) foi atribuída a competência de estabelecer critérios e diretrizes para alocação dos recursos do fundo. O Conselho Nacional das Cidades assumiu um papel de monitoramento e a avaliação da $\mathrm{PNH}$, especialmente no que se refere à HIS. A CAIXA ${ }^{37}$ manteve sua condição de agente

\footnotetext{
${ }^{37}$ Bonduki (2009, p. 124) ressalta que, apesar do avanço que representou a criação do MCidades, uma de suas deficiências é sua fragilidade institucional frente à megaestrutura da CAIXA, com 60.000 funcionários e subordinada ao Ministério da Fazenda. Na teoria, o MCidades é o responsável pela gestão da política habitacional, contudo, na prática, devido à enorme capilaridade e poder da CEF, presente em todos os municípios do país, acaba por fazer com que as decisões sobre a aprovação dos pedidos de financiamento e acompanhamento das empresas permaneçam integralmente nas mãos do agente financeiro.
} 
operador do sistema, função que lhe foi atribuída desde a extinção do BNH, tanto para os programas promovidos com recursos do FGTS, como para aqueles desenvolvidos pelo FNHIS. Por sua vez, estados e municípios receberam a atribuição de atuar como agentes descentralizados, com responsabilidades específicas no que se refere à habitação no âmbito local, implementando os programas concebidos no âmbito federal.

Ainda na primeira gestão de Lula (2003-2006), em que pese a manutenção de uma política econômica conservadora, observamos um processo de lenta modificação dos programas habitacionais financiados com recursos do FGTS, que haviam sido estruturados ainda no governo $\mathrm{FHC}$, com o objetivo de priorizar o atendimento à faixa da população com renda até 5 salários (BONDUKI, 2009). Essa mudança normativa, juntamente com a criação de novos programas (em destaque no Quadro 6) e a aprovação de resoluções pelo Conselho Curador do FGTS, permitiram a ampliação dos subsídios para a população de baixa renda (AZEVEDO, 2007).

Quadro 6 - Programas habitacionais trabalhados pelo MCidades

\begin{tabular}{|c|c|c|c|}
\hline PROGRAMA & AÇÃO & MODALIDADE & FONTE \\
\hline \multirow{2}{*}{$\begin{array}{l}\text { Urbanização, } \\
\text { Regularização e } \\
\text { Integração de } \\
\text { Assentamentos } \\
\text { Precários }\end{array}$} & $\begin{array}{l}\text { Apoio à Melhoria das Condições de } \\
\text { Habitabilidade de Assentamentos Precários }\end{array}$ & - & \multirow{2}{*}{ FNHIS } \\
\hline & Urbanização de Assentamentos Precários & - & \\
\hline \multirow{5}{*}{$\begin{array}{l}\text { Habitação de } \\
\text { Interesse Social }\end{array}$} & \multirow{4}{*}{$\begin{array}{l}\text { Apoio à Provisão Habitacional de Interesse } \\
\text { Social }\end{array}$} & $\begin{array}{l}\text { Produção ou aquisição de } \\
\text { unidades habitacionais }\end{array}$ & \multirow{5}{*}{ FNHIS } \\
\hline & & $\begin{array}{l}\text { Produção ou aquisição de lotes } \\
\text { urbanizados }\end{array}$ & \\
\hline & & Requalificação de Imóveis & \\
\hline & & Assistência Técnica & \\
\hline & $\begin{array}{l}\text { Apoio à Elaboração de Planos Habitacionais } \\
\text { de Interesse Social }\end{array}$ & - & \\
\hline $\begin{array}{l}\text { Intervenções em } \\
\text { Favelas }\end{array}$ & $\begin{array}{l}\text { Implantação de ações integradas de } \\
\text { habitação, saneamento e inclusão social } \\
\text { necessárias à regularização fundiária, } \\
\text { segurança, salubridade e habitabilidade de } \\
\text { populações localizadas em áreas } \\
\text { inadequadas à moradia. }\end{array}$ & - & OGU \\
\hline $\begin{array}{l}\text { PSH - Programa } \\
\text { de Subsídio à } \\
\text { Habitação de } \\
\text { Interesse Social }\end{array}$ & $\begin{array}{l}\text { Oferece acesso à moradia adequada a } \\
\text { cidadãos de baixa renda, em grupos } \\
\text { organizados, por intermédio da concessão de } \\
\text { subsídios. }\end{array}$ & - & OGU \\
\hline
\end{tabular}

André Carneiro, ex-arquiteto da HABITAFOR, ao afirmar que a CEF, por vezes, apresenta exigências que ultrapassam àquelas do município com relação a licenciamentos e aprovações de projetos, corrobora a análise de Bonduki (CARNEIRO, 2016). 


\begin{tabular}{|c|c|c|c|}
\hline PROGRAMA & AÇÃO & MODALIDADE & FONTE \\
\hline $\begin{array}{l}\text { PRÓ-MORADIA - } \\
\text { Programa de } \\
\text { Atendimento } \\
\text { Habitacional } \\
\text { através do Setor } \\
\text { Público }\end{array}$ & $\begin{array}{l}\text { Financiamento ao poder público (Distrito } \\
\text { Federal, estados, municípios) para o } \\
\text { desenvolvimento de ações integradas e } \\
\text { articuladas que resultem na melhoria da } \\
\text { qualidade de vida da população de menor } \\
\text { renda ou na produção de alternativas e } \\
\text { soluções habitacionais. }\end{array}$ & $\begin{array}{l}\text { Produção de conjuntos } \\
\text { habitacionais } \\
\text { Urbanização e regularização de } \\
\text { favelas } \\
\text { Desenvolvimento institucional }\end{array}$ & FGTS \\
\hline $\begin{array}{l}\text { Carta de Crédito } \\
\text { Individual }\end{array}$ & Financiamento direto a pessoas físicas. & $\begin{array}{l}\text { Aquisição, construção, } \\
\text { conclusão, ampliação, reforma ou } \\
\text { melhoria de unidade habitacional, } \\
\text { aquisição de material de } \\
\text { construção ou de lote. }\end{array}$ & FGTS \\
\hline \multirow[t]{2}{*}{$\begin{array}{l}\text { Carta de Crédito } \\
\text { Associativo }\end{array}$} & $\begin{array}{l}\text { Financiamento a pessoas físicas, organizadas } \\
\text { em condomínios, sindicatos, cooperativas, } \\
\text { associações, companhias de habitação ou } \\
\text { empresas do setor da construção civil. }\end{array}$ & $\begin{array}{l}\text { Produção de lote urbanizado, } \\
\text { construção de unidade } \\
\text { habitacional ou aquisição de } \\
\text { unidade nova, }\end{array}$ & \multirow[t]{2}{*}{ FGTS } \\
\hline & $\begin{array}{l}\text { Financiamento da reforma de prédios para } \\
\text { ocupação residencial. }\end{array}$ & Reabilitação habitacional & \\
\hline Apoio à Produção & $\begin{array}{l}\text { Financiamento à pessoa jurídica para } \\
\text { produção de empreendimentos habitacionais. }\end{array}$ & $\begin{array}{l}\text { Até } 5 \text { salários mínimos } \\
\text { Acima de } 5 \text { salários mínimos }\end{array}$ & FGTS \\
\hline Crédito Solidário & $\begin{array}{l}\text { Financiamento a pessoas físicas com juros } \\
\text { zero, organizadas em cooperativas } \\
\text { habitacionais ou mistas, associações e } \\
\text { demais entidades sem fins lucrativos. }\end{array}$ & $\begin{array}{l}\text { Produção de novas habitações, } \\
\text { conclusão e } \\
\text { reforma de moradias }\end{array}$ & FDS \\
\hline $\begin{array}{l}\text { PAR - } \\
\text { Arrendamento } \\
\text { Residencial }\end{array}$ & $\begin{array}{l}\text { Arrendamento de empreendimentos a } \\
\text { construir, em construção ou recuperação, com } \\
\text { opção de compra. }\end{array}$ & $\begin{array}{l}\text { Aquisição de unidades } \\
\text { habitacionais }\end{array}$ & FAR \\
\hline
\end{tabular}

Fonte: Ministério das Cidades (BRASIL, 2007a), elaboração do autor

Em 2005, uma pequena reforma ministerial foi realizada como tentativa de recompor ou minimizar a perda da base parlamentar do governo, que se encontrava em meio a uma crise política decorrente do "Escândalo do Mensalão". O MCidades foi sacrificado em nome da governabilidade e passou para o comando do Partido Progressista (PP) que, apesar do nome, possui um caráter conservador (AZEVEDO, 2007; LEITÃO, 2009; MARICATO, 2014) ${ }^{38}$.

Essa ruptura foi decisiva para a continuidade de alguns projetos que vinham se delineando dentro do ministério. É o caso, por exemplo, da orientação [...] de integrar as diretrizes da política urbana a uma leitura regional da dimensão territorial do desenvolvimento (LEITÃO, 2009, p. $210-211)^{39}$.

38 "A primeira equipe que compôs o time que dirigiu o MCidades resultou numa convergência também rara de militantes sindicalistas, profissionais e acadêmicos com participação anterior em experiências de administração pública e muito prestigiadas no meio técnico e acadêmico, além de forte inserção nos movimentos sociais urbanos" (MARICATO, 2014, p. 37).

39 Outras iniciativas também encontraram dificuldades em serem implementadas devido às mudanças no comando do MCidades, como o Plano Nacional para Regiões Metropolitanas, o Plano Nacional de Desenvolvimento Urbano e o Plano Nacional de Habitação (LEITÃO, 2009). Segundo Maricato (2014), nenhuma das propostas de orientação para a PNDU tiveram seguimento após a saída em 2005 da equipe do ministro das cidades, Olívio Dutra. Para a autora, após a mudança no comando do MCidades 
No segundo mandato (2007-2010), o governo Lula adota um discurso pela retomada do crescimento econômico, com o foco em um Estado forte, procurando investir na construção de infraestrutura econômica e social, bem como no fortalecimento dos conglomerados brasileiros privados, a fim de torná-los competitivos no mercado internacional (MARICATO, 2014). Deste modo, em janeiro de 2007 é lançado o Programa de Aceleração do Crescimento (PAC), concebido para estimular o crescimento econômico do Brasil. Constavam no PAC projetos e obras nas áreas de: Logística, em rodovias, ferrovias, portos e aeroportos; Energia, em geração e distribuição de energia, combustíveis renováveis, petróleo e gás natural; e Infraestrutura social e urbana, em saneamento, habitação, recursos hídricos e iluminação pública (MARICATO, 2014).

Para Leitão (2009) o PAC acabou por constituir um conjunto de intenções dispersas e desarticuladas, reproduzindo a "tradição" brasileira de implantação de planos sem projetos e projetos sem planos, e as contradições entre planejamento regional e políticas setoriais, por isso não deve ser compreendido como um programa integrado de desenvolvimento.

Entre 2007 e 2008, foi elaborado o Plano Nacional de Habitação (PlanHab), o instrumento para a implantação da PNH previsto na lei no 11.124/2005 do SNHIS. Seu objetivo principal era "estruturar uma estratégia para enfrentar a questão habitacional e urbana [...] buscando articular uma política de inclusão com o desenvolvimento econômico do país" (BRASIL, 2009, p. 10). Para isso, foram estabelecidos cenários, metas físicas e financeiras, modelagens de financiamento e propostas políticas, institucionais e para a cadeia produtiva da habitação (LEITÃO, 2009). Além disso, como forma de tentar articular o PlanHab aos instrumentos de planejamento orçamentário-financeiros do Governo Federal, foi proposto um horizonte temporal sincronizado com os Planos Plurianuais (PPA's), tendo o ano de 2023 como horizonte final e revisões periódicas nos anos de elaboração dos PPA's, 2011, 2015 e 2019 (BRASIL, 2009).

té mesmo o Projeto Moradia foi esquecido em sua premissa maior de articulação entre a política urbana/fundiária e a política habitacional. 
No contexto de tensão econômica internacional, iniciada com a crise das hipotecas nos Estados Unidos em 2008, o governo federal lança um pacote habitacional com uma "série de medidas destinadas a estimular a produção habitacional e manter o desenvolvimento dos setores imobiliários e da construção civil” (ROLNIK e NAKANO, 2009). Antes mesmo da divulgação do PlanHab, é lançado em março de 2009 o Programa Minha Casa, Minha Vida (PMCMV) ${ }^{40}$ com uma meta inicial de construir 1 milhão de casas para famílias com rendas até dez salários mínimos, divididas em três faixas: Faixa 1 - zero a três salários mínimos; Faixa 2 - três a seis salários mínimos; e Faixa 3 - seis a dez salários mínimos.

O Pacote Habitacional não levou em conta as medidas propostas de maneira articulada ao PLANHAB, mas apropriou-se de mecanismos sugeridos no plano de maneira parcial, restringindo-se às ações de curto prazo, limitando-se a incorporar algumas das medidas de financiamento (como por exemplo, a criação de um fundo garantidor para cobrir inadimplências de mutuários de baixa renda) (LEITÃO, 2009, p. 212).

Podemos perceber que a lógica do PMCMV permitiu uma implementação dos empreendimentos que ignorasse a política para habitação de interesse social que se delineava, passando ao largo da mencionada estrutura "CPF", conselho, plano e fundo. O próprio PAC acabou sendo alterado e passou a ter o PMCMV, Fase 2, como o meio para a provisão habitacional em suas obras de urbanização de favelas, com a vinculação dos empreendimentos do PMCMV ao reassentamento de famílias oriundas de intervenções geradoras de remoções (AMORE, 2015).

O contexto nacional relativo às políticas urbanas e habitacional nas primeiras décadas do século XXI foi brevemente descrito, pois terá forte reflexo na política habitacional implementada pelo município de Fortaleza nesse período.

Como vimos, até o ano de 2004, a política habitacional em Fortaleza ocorria de modo desarticulado e acéfalo, com ações dispersas em vários órgãos. As componentes de

\footnotetext{
40 "O Minha Casa Minha Vida é, na origem, um programa econômico. Foi concebido pelos ministérios de 'primeira linha' - Casa Civil e Fazenda - em diálogo com o setor imobiliário e da construção civil, e lançado como Medida Provisória (MP 459) em março de 2009, como uma forma declarada de enfrentamento da chamada crise dos subprimes americanos que recentemente tinha provocado a quebra de bancos e impactado a economia financeirizada mundial" (AMORE, 2015, p. 17). Na sua Fase 1 , que foi de abril de 2009 a junho 2011, foram contratadas 1 milhão de unidades habitacionais e na sua Fase 2, que foi de junho de 2011 a dezembro de 2014, foram contratadas mais 2 milhões de unidades (AMORE, 2015).
} 
desenvolvimento institucional, obrigatórias pelo Programa Habitar Brasil/BID, vinham sendo elaboradas, na gestão Juraci, de modo lento e apenas com o objetivo de garantir recursos para a realização das obras de urbanização e reassentamento da Lagoa do Opaia, já em fase de execução, e da Comunidade Maravilha, que ainda se encontrava em etapa de elaboração do projeto em 2004, ao final da gestão.

As eleições municipais de 2004 em Fortaleza trouxeram mudanças administrativas, com a surpreendente vitória de Luizianne Lins (PT) para prefeita. Este processo eleitoral merece algumas considerações, pois ele terá decorrências diretas no desenvolvimento da política habitacional no município e na ascensão da HABITAFOR.

O candidato natural do campo progressista para as eleições em 2004 era Inácio Arruda do PC do B. Inácio já havia disputado o segundo turno nas eleições de 2000, concorrendo com o então prefeito Juraci Magalhães, e, no que se refere à questão urbana, enquanto deputado federal, havia sido o relator da lei do Estatuto da Cidade. O então presidente Lula e o diretório nacional do PT indicavam o apoio à Inácio para o pleito (LIMA, 2014), contudo Luizianne Lins consegue lançar sua candidatura à revelia do próprio partido e, surpreendentemente, chega ao segundo turno e à vitória.

Ao passar para o segundo turno, Luizianne recebe o apoio de Inácio Arruda e dentre os conteúdos programáticos absorvidos, nesse processo de apoio político, estavam propostas relacionadas às temáticas urbana e habitacional, que historicamente eram bandeiras da militância do PC do B em Fortaleza, diferentemente do PT local, que não atribuía relevância a essas temáticas em seus debates internos (RODRIGUES, 2016). Tanto é que o programa de governo de Luizianne Lins para a questão da habitação só veio a ser elaborado durante o segundo turno da campanha eleitoral, por profissionais que já militavam na questão através de ONG's e movimentos sociais e que, por isso, possuíam maior proximidade com o candidato Inácio Arruda (PEQUENO, 2011, MARQUES, 2016 e RODRIGUES, 2016).

Na montagem do governo Luizianne, os órgãos e secretarias foram partilhados entre os partidos que apoiaram sua candidatura, deixando técnicos que haviam participado dos debates para a elaboração de seu programa de governo de fora (PEQUENO, 
2011). Assim, a HABITAFOR foi destinada ao PC do $B$, muito mais pela não identificação do próprio PT local com a temática ${ }^{41}$.

Contudo, o fato da prefeita eleita integrar uma tendência interna do PT, a Democracia Socialista (DS), que historicamente rivalizava com o $\mathrm{PC}$ do $\mathrm{B}^{42}$, pode ter levado à rejeição do nome indicado pelo $\mathrm{PC}$ do $\mathrm{B}$, que era o de Eliana Gomes, então presidente da Federação de Bairros e Favelas de Fortaleza (FBFF) (RODRIGUES, 2016). Luizianne optou pelo nome da socióloga Olinda Marques, membro da ONG CEARAH Periferia (CP), instituição reconhecida por sua atuação na questão da habitação social, e que havia sido eleita Conselheira Nacional das Cidades em 2003, portanto com uma experiência na área, mas que, apesar da sua proximidade com o PC do B de Inácio e Eliana, era filiada ao PT.

Eliana e Olinda possuíam uma relação próxima devido à militância na questão habitacional em Fortaleza. Tanto a FBFF quanto o CP compunham, junto com outras instituições, como a Cáritas Arquidiocesana e o CDPDH, o Núcleo de Habitação e Meio Ambiente (NUHAB) ${ }^{43}$, que desde o começo dos anos 2000 vinha monitorando as ações habitacionais desenvolvidas na gestão Juraci Magalhães pela COMHAB e posteriormente pela HABITAFOR, bem como a situação das áreas de risco de Fortaleza, através do Fórum das Áreas de Risco. Assim, a opção pelo nome de Olinda Marques na presidência da HABITAFOR foi complementada com o nome de Eliana Gomes para compor a gestão do órgão, como forma de agradar tanto o PT, quanto o $\mathrm{PC}$ do $\mathrm{B}$.

Ainda em 2004, a equipe responsável pela transição política passou a conhecer de fato a realidade da HABITAFOR, que se constituía de uma pequena coordenadoria, praticamente sem orçamento e apresentava uma estreita relação com o gabinete do

\footnotetext{
${ }^{41}$ As secretárias que possuíam temáticas coincidentes com bandeiras de luta do PT local, como saúde e educação, foram destinadas a membros do partido (RODRIGUES, 2016).

42 Desde o movimento estudantil, a DS disputa com o PC do B cargos na direção de instituições, como o Diretório Central dos Estudantes (DCE) da Universidade Federal do Ceará (UFC) e na União Nacional dos Estudantes (UNE) (RODRIGUES, 2016).

${ }^{43}$ Nas palavras de Olinda Marques, "o NUHAB era a representação em Fortaleza do Fórum da Reforma Urbana" que, seguindo uma determinação nacional, agregava diversas instituições da sociedade civil (MARQUES, 2016). Um dos projetos do NUHAB era o monitoramento passo a passo das ações da prefeitura de Fortaleza em relação à questão da habitação, como uma tentativa de assumir uma espécie de controle social sobre a instituição (PEQUENO, 2011).
} 
prefeito (MARQUES, 2016), apesar de sua vinculação legal com a SEINF. Existia apenas uma intervenção com obras em andamento, na Lagoa do Opaia e uma outra pré-aprovada, na Comunidade Maravilha, que estava com o prazo de entrega do projeto executivo para a CEF se esgotando (PEQUENO, 2011 e MARQUES, 2016), portanto, exigia rapidez na finalização da proposta, sob o risco de perda do recurso.

Outro problema existente era a composição dos funcionários do órgão, que se constituía basicamente de cargos comissionados de confiança da gestão anterior e mantinham uma visão clientelista da política habitacional (PEQUENO, 2011). Nas palavras de Gondim, "os recursos materiais e humanos necessários ao seu funcionamento eram insuficientes, ante a tarefa hercúlea de fazer frente aos graves problemas da moradia popular em Fortaleza, acumulados ao longo de décadas de descaso" (GONDIM, 2013, p. 155). A situação exigia uma reestruturação do órgão praticamente partindo do zero.

Segundo Pequeno (2011), a estrutura pensada para a HABITAFOR pela equipe de transição buscava estruturar o básico para a implementação de uma política habitacional, ou seja, ter a provisão habitacional, a urbanização de favela e a regularização fundiária. Mas também foi idealizada a existência de um setor para pensar à frente do tempo, para elaborar projetos pilotos, como um projeto de assistência técnica ou um projeto para habitação social no centro de Fortaleza.

Ao analisarmos a estrutura da HABITAFOR nesse momento inicial, percebemos que ela se relacionava às estratégias delineadas na lei da PHIS ${ }^{44}$. Havia uma Coordenação de Programas Habitacionais $(\mathrm{CPH})^{45}$, responsável pela elaboração dos projetos das intervenções, bem como pela fiscalização das obras, relacionando-se às estratégias "Nossa morada" e "Qualidade de Vida" da PHIS. Uma outra coordenação era responsável pelas ações de regularização fundiária, trabalhando tanto antigos conjuntos construídos pelo município, como intervenções em andamento no momento

\footnotetext{
44 Muitos dos arquitetos entrevistados para esta pesquisa, ex-funcionários da HABITAFOR, simplesmente desconheciam a lei da Política Habitacional de Interesse Social - PHIS, ou tinham um conhecimento superficial, apesar de, na prática, o órgão lidar com as estratégias da PHIS.

45 Durante a primeira gestão Luizianne, a CPH também era responsável pelo trabalho social nas intervenções, através da Célula de Assistência de Social (CAS). Com as mudanças ocorridas na HABITAFOR durante o segundo mandato de Luizianne, entre 2009 e 2012, a CAS adquiriu status de coordenação, deixando de ser vinculada à $\mathrm{CPH}$, que ficou apenas a cargo da elaboração dos projetos e da fiscalização das obras.
} 
e áreas de assentamentos precários, que se relacionavam à estratégia "Viver Tranquilo".

Um setor específico trabalhava com um programa chamado "Casa Bela"46, responsável por ações de melhorias habitacionais, relacionando-se à estratégia "Morar Melhor". Mesmo funcionando dentro das instalações da HABITAFOR, esta não possuía muita ingerência sobre o "Casa Bela", devido ao fato do programa funcionar com recursos do Fundo Municipal de Desenvolvimento Social (FMDS), gerido pela Secretaria de Planejamento (SEPLA), mas conseguiu contribuir para a alteração de alguns pontos do programa, como critérios de acesso e valor do benefício (RODRIGUES, 2016). Nos programas realizados em parceria com o governo federal, também era prevista a realização de melhorias habitacionais, a serem executadas pelas empreiteiras vencedoras das licitações.

Havia também o setor de Projetos Especiais que conduzia projetos específicos, como o Plano de Reabilitação do Centro, o Plano Local de Habitação de Interesse Social de Fortaleza (PLHISFor), o projeto de reforma para uma nova sede do órgão, entre outros. Este setor também ficou responsável pelo planejamento geral da HABITAFOR, elaborando previsões orçamentárias, bem como os processos de captação de recursos, através do envio de propostas de intervenção nas sistemáticas do MCidades.

Alguns fatores favoreceram a atuação de Olinda Marques na HABITAFOR. Primeiramente, o governo federal já vinha reestruturando o setor urbano/habitacional desde 2003 e estava retomando os investimentos na área, com o aumento do volume de recursos disponíveis. Em segundo lugar, a equipe do Ministério das Cidades, naquele momento, possuía na sua composição alguns militantes da questão da urbana, já conhecidos por Olinda devido a sua atuação à frente do CEARAH Periferia e como conselheira nacional das cidades. Havia, inclusive, o repasse de informações privilegiadas, como a previsão de lançamentos de programas ou sistemáticas para a captação de recursos, como ela mesmo afirma:

${ }^{46}$ O "Casa Bela" deu continuidade ao programa "Casa Melhor" que foi implementado pela ONG CEARAH Periferia em parceria com a Prefeitura de Fortaleza, na gestão Juraci Magalhães. Através do "Casa Bela", famílias com renda até três salários mínimos e integrantes de associações de moradores obtinham empréstimos para realizarem pequenas reformas em suas moradias. 
[...] nós pegamos, formamos uma equipe boa e montamos uma sala de projeto, pra poder nos preparar pra o que vinha, porque eu tinha informações privilegiadas, porque eu tinha amigos lá. Então eles me falavam: "olha, nós vamos lançar o PAC pra ajudar os municípios. Então, se prepara aí. Procura saber quais os projetos você pode captar". [...]. Então, essas informações foram muito boas, foram sine qua non pra gente se preparar. Isso é o bom de você tá com um governo articulado. O governo daqui articulado com o governo de lá (MARQUES, 2016).

2005 foi um ano de estruturação para a HABITAFOR, tanto no que se refere à questão dos recursos humanos, quanto à questão de infraestrutura física, de equipamentos, computadores, mobiliário, entre outros. Para remediar a situação, buscou-se implementar algumas ações de desenvolvimento institucional do PHBB que havia sido relegadas pela gestão anterior, o que permitiu a aquisição de alguns equipamentos para estruturação do órgão.

Em relação à composição da equipe de trabalho, assim como no MCidades, a HABITAFOR, nesse momento inicial, também contaou com alguns militantes da questão habitacional em Fortaleza. Gondim descreve a situação do órgão em relação a sua estrutura nesse período:

A Habitafor não dispunha de um staff permanente: além de alguns técnicos do quadro da administração municipal cedidos pelos órgãos de origem, os demais eram nomeados para cargos comissionados ou contratados por serviços prestados. As condições de trabalho eram desfavoráveis: infraestrutura deficiente, baixos salários, longas horas de trabalho. A atuação junto a comunidades a serem reassentadas exigia flexibilidade de horário, o que significava, por vezes, trabalhar mais de oito horas por dia e até nos fins de semana e feriados. Mesmo assim, a primeira presidente da Habitafor formou uma equipe bastante motivada, integrada por recém-formados, cuja falta de experiência na administração pública era, até certo ponto, contrabalançada pela familiaridade com o trabalho junto a comunidades de baixa renda (GONDIM, 2013, p. 156).

Um dos desafios era estabelecer uma sala técnica para a elaboração de projetos que possibilitassem a captação de recursos junto ao governo federal (MARQUES, 2016 e BISIO, 2016). A boa receptividade que a presidente da HABITAFOR possuía junto ao MCidades, foi vista pela prefeita de Fortaleza como uma oportunidade de angariar recursos para o município. Assim, o órgão passou a receber um maior apoio para sua estruturação, em especial para contratação, apesar dos números sempre terem 
permanecido abaixo das necessidades do órgão e das aspirações de sua presidente (RODRIGUES, 2016) ${ }^{47}$.

Mesmo com os obstáculos mencionados, ainda em 2005 a HABITAFOR começou a elaborar projetos. Nesse primeiro momento, houve uma continuidade da lógica de atuação da COMHAB, com uma busca pela utilização de terrenos do Fundo de Terras ${ }^{48}$ para implantação de conjuntos, já que o município não possuía recursos para a aquisição de terrenos (RODRIGUES, 2016 e CARNEIRO, 2016). Contudo, iniciouse uma busca pela vinculação das ações à hierarquização das áreas de risco definida no PEMAS (RODRIGUES, 2016 e BISIO, 2016) ${ }^{49}$.

A ex-coordenadora de programas habitacionais, Larissa Bisio, lembra ainda que, além da vinculação à hierarquização do PEMAS, a disponibilidade de terrenos era um fator determinante na definição de uma comunidade a ser trabalhada. Segundo ela, seguiase a lista caso houvesse terreno disponível. Não havendo, passava-se para a próxima área de risco da lista. Até mesmo a própria Olinda solicitava às comunidades que apresentassem terrenos para que a HABITAFOR trabalhasse (BISIO, 2016).

\footnotetext{
47 Ao final do ano de 2005, a HABITAFOR inteira possuía cerca de 30 profissionais, praticamente o mesmo número que havia na COMHAB. Entre 2005 e 2006, só o setor técnico de projetos saltou de 5 profissionais (entre coordenador, gerentes, arquitetos, engenheiros e apoio, sem contar com estagiários) para 19 profissionais, chegando a 24 em 2012, ao final da gestão Luizianne. A HABITAFOR terminou a gestão Luizianne com 310 funcionários, conforme apresentação do Instituto de Planejamento de Fortaleza (IPLANFOR), no processo de atualização do PLHISFor. Convém ressaltar que havia funcionários contratados pela HABITAFOR, através do convênio com a Fundação Cearense de Pesquisa e Cultura (FCPC) da UFC, que atuavam em outros órgãos do município, como a SEPLA e Escritório do projeto Vila do Mar (RODRIGUES, 2016). Outro ponto importante a ser destacado é que nunca foi realizado concurso para dotar a HABITAFOR de servidores próprios, desde a sua criação em 2003, até os dias de hoje, em 2017. Seus funcionários ou eram servidores emprestados de outros órgãos, ou eram cargos comissionados de livre nomeação pelo gestor, ou eram terceirizados, inicialmente através do convênio com a FCPC e, posteriormente, através de contrato com uma empresa terceirizadora de mão de obra. Isso terá forte repercussão na grande rotatividade dos profissionais, que acabavam passando pouco tempo no órgão e levavam consigo o conhecimento técnico adquirido com a experiência do trabalho.

48 A gestão dos terrenos do Fundo de Terras era legalmente atribuída à HABITAFOR em sua lei de criação, $n^{\circ}$ 8.810/2003, contudo, o controle patrimonial era feito por um setor da SEINF, no qual não havia um banco de dados sistematizados, apenas um arquivo físico desorganizado, com funcionários que demonstravam querer manter um monopólio sobre as informações (RODRIGUES, 2016). A HABITAFOR dependia de que os profissionais deste setor enviassem listas com os imóveis disponíveis no Fundo de Terras, que, em muitos casos, tratavam-se de terrenos parcialmente ou completamente inadequados à construção habitacional (BISIO, 2016 e RODRIGUES, 2016).

${ }^{49}$ Mesmo com a discordância da presidente da HABITAFOR, Olinda Marques, em relação aos métodos empregados na elaboração dos estudos, tanto do PEMAS, quanto da PHIS, posto que ela já monitorara estes processos através do NUHAB, procurou-se utilizar a hierarquização das áreas de risco (MARQUES, 2016).
} 
No início desta pesquisa acreditávamos que o Orçamento Participativo $(\mathrm{OP})^{50}$ era a instância em que as demandas habitacionais eram definidas pelos representantes das comunidades, o que atribuiria um caráter participativo à política. $\mathrm{Na}$ realidade, identificamos que o fator preponderante na definição das áreas a serem trabalhadas eram negociações realizadas entre presidência da HABITAFOR e movimentos sociais, geralmente a ela alinhados (BISIO, 2016 e RODRIGUES, 2016) ${ }^{51}$. Borges (2012) reforça essa percepção ao afirmar que a equipe social da HABITAFOR, ao realizar as primeiras visitas às comunidades eleitas no OP para receber intervenções, a fim de reconhecer a área e elaborar o diagnóstico social, notava que as famílias não tinham conhecimento do processo.

No processo do OP, especialmente na primeira gestão Luizianne, as demandas eleitas pelas comunidades passavam por uma espécie de triagem de viabilidade pelos órgãos municipais, uma vez que não existia a garantia de recursos para as ações escolhidas. O OP apenas atribuía um caráter de prioridade, diferentemente do que acontecia com o PAC, por exemplo, que garantia o descontingenciamento dos recursos para as intervenções incluídas no programa (RODRIGUES, 2016). Havia um espaço para a negociação das demandas entre as comunidades demandantes e os gestores dos órgãos, principalmente no que se referia à dimensão quantitativa, pois era frequente o caso de solicitações de grande porte que inviabilizariam o atendimento a outras áreas da cidade (RODRIGUES, 2016).

No caso da HABITAFOR, as demandas do OP que eram selecionadas eram justamente aquelas que já haviam sido previamente acordadas entre presidência e movimentos, e que, preferencialmente, já possuíssem recursos captados junto ao governo federal, através das sistemáticas do MCidades, para realização de intervenções (BISIO, 2016 e RODRIGUES, 2016). Como as sistemáticas exigiam uma espécie de levantamento prévio de informações sobrea as áreas a serem trabalhadas, mesmo que de modo superficial, sem maiores detalhamentos, a HABITAFOR

\footnotetext{
50 O Orçamento Participativo virou uma marca das gestões petistas, tornando-se muito conhecido após sua aplicação em Porto Alegre - RS. No OP, a população tem a possibilidade de decidir sobre a destinação de uma parte pré-definida dos recursos municipais.

51 Gondim (2013, p. 157) também apresenta um pensamento semelhante, de que a decisão sobre quais comunidades receberiam intervenções era fortemente influenciada por demandas de representantes comunitários apresentadas no OP. Contudo, as entrevistas realizadas para a pesquisa revelaram um certo caráter clientelista na definição das demandas a serem trabalhadas pela HABITAFOR.
} 
costumava sempre enviar no ano seguinte as propostas que não haviam sido contempladas no ano anterior, acrescidas de novas propostas para outras áreas definidas pela presidência do órgão, que, em geral, não constavam na lista da hierarquização das áreas de risco do PEMAS (RODRIGUES, 2016).

No Quadro 7, podemos ver que as intervenções habitacionais do período entre 2005 e 2012 recorriam quase sempre a recursos do governo federal. Apenas três intervenções contaram com recursos exclusivamente municipais, nas demais o município entrava com uma contrapartida, mas a maior parte do recurso provinha de repasses federais, o que demonstra uma dependência da prefeitura nesse quesito. Houve até uma certa diversidade dos programas utilizados, com predominância para o PAC, que possuía uma linha de ação voltada para a provisão habitacional e a urbanização de favelas.

O Quadro 7 mostra que praticamente todas as demandas trabalhadas pela HABITAFOR eram demandas do OP. Demandas antigas, como os casos das intervenções Maravilha, Rosalina e PREURBIS - Cocó, tinham projetos que remontavam à gestão Juraci Magalhães, e também foram incluídas nas demandas do OP, demonstrando que o OP não era uma instância participativa, de fato, na definição das demandas, mas que atribuía um caráter de prioridade aos investimentos.

Quadro 7 - Intervenções habitacionais da HABITAFOR entre 2003 e 2012

\begin{tabular}{lllrr}
\hline INTERVENÇÃo & PROGRAMA & DEMANDA & $\begin{array}{r}\text { U.H. } \\
\text { PREV. }\end{array}$ & $\begin{array}{r}\text { E.H. } \\
\text { EXEC. }\end{array}$ \\
\hline Açude João Lopes & PAC & Orçamento Participativo & 80 & 80 \\
Anita Garibaldi & Municipal & Orçamento Participativo & 20 & 20 \\
Autran Nunes & Municipal & Espontânea & 3 & 3 \\
Bárbara de Alencar I & OGU & Orçamento Participativo & 104 & 104 \\
Bárbara de Alencar II & PSH & Espontânea & 284 & 100 \\
Casa e Renda & OGU & Institucional & 20 & 20 \\
Itaperussu & Operações Coletivas & Institucional & 88 & 0 \\
Jana Barroso & Resolução 460 & Orçamento Participativo & 272 & 256 \\
Lagoa da Zeza e Vila Cazumba / & Palafitas Zero & Orçamento Participativo & 1.128 & 1.126 \\
Maria Tomásia & & & 504 & 504 \\
Lagoa do Opaia / Planalto & PHBB & Institucional & 488 & 92 \\
Universo & PAC & Orçamento Participativo & 48 \\
Lagoa do Papicu & PAC & Orçamento Participativo & 188 & 44 \\
Lagoa do Urubu & & &
\end{tabular}




\begin{tabular}{|c|c|c|c|c|}
\hline INTERVENÇÃO & PROGRAMA & DEMANDA & $\begin{array}{l}\text { U.H. } \\
\text { PREV. }\end{array}$ & $\begin{array}{l}\text { U.H. } \\
\text { EXEC. }\end{array}$ \\
\hline Maravilha & PHBB & Institucional & 606 & 606 \\
\hline Marrocos & OGU & Orçamento Participativo & 147 & 72 \\
\hline Planalto Pici & Pró-Moradia & Institucional & 80 & 80 \\
\hline PREURBIS - Cocó ${ }^{1}$ & PREURBIS & Orçamento Participativo & 816 & 0 \\
\hline Rosa Luxemburgo & Municipal & $\begin{array}{l}\text { Espontânea / Orçamento } \\
\text { Participativo }\end{array}$ & 171 & 171 \\
\hline Rosalina $^{2}$ & Pró-Moradia & Orçamento Participativo & 1.807 & 412 \\
\hline Sabiá & Operações Coletivas & Orçamento Participativo & 72 & 56 \\
\hline São Cristóvão / Campo Estrela & PAC & Orçamento Participativo & 440 & 19 \\
\hline Socorro Abreu & Operações Coletivas & Orçamento Participativo & 62 & 62 \\
\hline Urucutuba & Operações Coletivas & Espontânea & 332 & 0 \\
\hline Vila do Mar ${ }^{1}$ & PAC & Orçamento Participativo & 1.434 & 264 \\
\hline TOTAL & & & 9.146 & 4.091 \\
\hline
\end{tabular}

Nota: 1 - Projetos concebidos fora da HABITAFOR, que posteriormente assumiu a fiscalização de obras ou a execução do trabalho social.

Fonte: Habitafor

As demandas que classificadas como "Institucional" são aquelas com origem internamente ao próprio órgão, como o caso do projeto Casa e Renda, um projeto piloto que buscou aliar habitação e geração de renda. Já as demandas que classificamos como "Espontânea" surgiram fora da instância do OP ou do órgão, como no caso do projeto Autran Nunes, que visava atender três famílias vítimas da explosão de um botijão de gás que destruiu suas casas.

Buscava-se capitalizar politicamente com a realização dos projetos, não apenas para a gestão municipal, mas também para os gestores do órgão. Deste modo, Eliana Gomes, que entre 2005 e 2008 foi coordenadora da Assessoria Comunitária da HABITAFOR, um setor que tinha uma estreita relação com os movimentos sociais, elegeu-se vereadora para o mandato 2009-2012. Não por coincidência o projeto Açude João Lopes, que estava na última posição da hierarquização das áreas de risco do PEMAS (Quadro 3), localiza-se em uma área da base eleitoral de Eliana Gomes, nas proximidades do bairro Ellery.

Apesar da tentativa inicial de centralizar as ações habitacionais na HABITAFOR, algumas iniciativas foram conduzidas por outros órgãos da prefeitura. Enquadram-se neste caso os projetos Rosalina, PREURBIS - Cocó, capitaneados pela SEINF, e Vila do Mar, conduzido por um setor criado especificamente para este fim, ligado 
diretamente ao gabinete da prefeita. Pequeno (2011) e Máximo (2012) apontam como motivação para isso o retorno político que ações como a construção de conjuntos habitacionais podem trazer a seus "autores", digamos assim, e a falta de interesse da gestão municipal em comprar a briga pela centralização de todas as ações habitacionais na HABITAFOR. Por sua vez, Marques (2016) vê como razão para a realização desses projetos habitacionais fora da HABITAFOR, a força política dos gestores desses outros órgãos.

Bisio (2016), Rodrigues (2016) e Carneiro (2016) também apontam que, para além do retorno político, tratavam-se de projetos antigos. Tanto o Rosalina, como o PREURBIS - Cocó já vinham sendo formatados pela Coordenadoria de Habitação que existia na SEINF desde a gestão Juraci Magalhães, herança dos anos de fragmentação da política habitacional.

Já o Vila do Mar tem origem em um projeto do Governo do Estado chamado CostaOeste que pretendia transformar a orla oeste de Fortaleza nos mesmos moldes da Avenida Beira-Mar, uma via paisagística com grande calçadão, o que implicava a remoção de inúmeras famílias para conjuntos periféricos, seguindo o modelo COHAB (RODRIGUES, 2016). As obras foram iniciadas em 2002 e embargadas diversas vezes por problemas com o licenciamento ambiental, até que, em 2006, em uma audiência pública provocada pela Procuradoria Geral da República, a prefeitura se propôs a assumir o projeto (DIÁRIO DO NORDESTE, 2008) e, posteriormente, transformou-o no que hoje conhecemos por Vila do Mar.

Assim, a SEINF, que foi reservada para o PSB, outro aliado do PT na campanha de Luizianne, buscava capitalizar politicamente com esses empreendimentos ${ }^{52}$. Já com o Vila do Mar, devido ao grande porte da intervenção, considerando o potencial de

\footnotetext{
52 Em razão de disputas político-partidárias, um terceiro projeto habitacional foi concebido pela SEINF, inclusive com recursos captados em 2010 junto ao governo federal, o Aldeia da Praia, na região do Serviluz (RODRIGUES, 2016). Após mudanças de gestão em 2013, o projeto Aldeia da Praia tem passado por reformulações e até o presente momento não foi tirado do papel. Segundo informações no site do Banco de Desenvolvimento da América Latina (CAF), a Prefeitura de Fortaleza conseguiu um empréstimo de 83,3 milhões de dólares junto ao CAF para a execução do "Programa Aldeia da Praia - Fortaleza Cidade com Futuro", que deverá ser executado pela Secretaria Municipal de Turismo, em vez da SEINF, ou da HABITAFOR, que deveria ser o órgão a cuidar das questões habitacionais (CAF, 2013).
} 
retorno político, a prefeita preferiu colocar uma pessoa de sua inteira confiança para tocar o projeto, constituindo um escritório com este único fim (RODRIGUES, 2016).

Curiosamente, a fiscalização das obras ou a realização do trabalho social nas três intervenções citadas, acabaram indo parar nas mãos da HABITAFOR. Por terem uma execução demasiado trabalhosa e demorada, em geral, os gestores das secretarias e órgãos não costumam se interessam por realizar este tipo de serviço, como foi o caso da SEINF, na Rosalina e no PREURBIS - Cocó, e do gabinete do Vila do Mar. Por sua vez, Olinda Marques, na visão de Rodrigues (2016), desejando mostrar ação e números, não hesitou em assumir a execução desses trabalhos, visualizando um potencial retorno eleitoral que poderia capitalizar, especialmente com o trabalho social. No caso do Vila do Mar, o fato da HABITAFOR ter realizado a captação dos recursos junto ao governo federal para a intervenção também favoreceu que o órgão assumisse a execução desses serviços.

Em julho de 2009, após a reeleição em primeiro turno da prefeita Luizianne Lins, ocorrem mudanças no secretariado municipal, uma forma costumeira dos gestores acomodarem a base aliada. As alterações levaram à saída de Olinda Marques da presidência da HABITAFOR, que assumiu a Secretaria Executiva Regional III, levando consigo toda a equipe de coordenadores e alguns técnicos. Roberto Gomes, ex-titular da Secretaria de Esporte e Lazer de Fortaleza assume a HABITAFOR no último dia do conturbado período de inscrições para o PMCMV, no qual as filas dobravam o quarteirão - eram mais de 80 mil inscritos para 25 mil unidades ofertadas (DIARIO DO NORDESTE, 2009).

Roberto Gomes não possuía nenhuma experiência com a questão habitacional e desconhecia completamente a política habitacional constituída pelo governo federal. No dizer popular, não era da área, mas, nas palavras de Gondim (2013, p. 156), era "um integrante da administração municipal cujo perfil era acentuadamente políticopartidário". Além de tudo, não tinha os contatos no MCidades que sua antecessora possuía. Desta forma, as portas que estiveram abertas para Olinda Marques se fecharam para Roberto Gomes, que não foi hábil o suficiente para mantê-las abertas ou reabri-las. Isso fica mais nítido quando percebemos que todas as intervenções implementadas pela HABITAFOR foram concebidas e tiveram recursos captados durante a gestão de Olinda. 
Para além da questão política de acomodação da nova base aliada no governo, pois o número de partidos que apoiavam Luizianne cresceu no segundo mandato, Bisio (2016) viu a mudança de gestão na HABITAFOR como consequência do destaque que o órgão teve na mídia e em relação ao volume de recursos captados, havia uma carteira de projetos em execução que despertava interesse de outros grupos políticos. Rodrigues (2016) corrobora essa visão quando relembra o potencial eleitoral da HABITAFOR, que possibilitou a eleição de Eliana Gomes para vereadora. Portanto, havia um interesse do grupo político da prefeita Luizianne em viabilizar outro candidato a vereador.

Roberto Gomes recebeu da antecessora obras com atrasos de pagamento e com problemas técnicos nos projetos, muitas vezes causados por uma elaboração apressada, que permitisse a captação de recursos. Por exemplo, muitos projetos foram elaborados sem a realização de um levantamento topográfico prévio ou sem o diagnóstico social finalizado, o que acarretava em realizar compatibilizações posteriores nos projetos, como afirmam Almeida (2016), Carneiro (2016) e Hatsue (2016). Em outros casos, as desapropriações dos terrenos de reassentamento não haviam se concretizado, o que impedia a execução do projeto já licitado. Problemas dessa ordem levaram a alterações em algumas intervenções, exigindo repactuações com a CEF, operadora dos programas do MCidades, além de paralizações nas obras e renegociações com as empreiteiras contratadas para a execução e com as comunidades abrangidas dos projetos.

A elaboração do Plano Local de Habitação de Interesse Social de Fortaleza (PLHISFor) foi provavelmente a ação mais importante realizada pela HABITAFOR durante a gestão Roberto Gomes. O plano era uma exigência do MCidades para municípios e estados que quisessem aderir ao SNHIS, contudo o processo de elaboração do PLHISFor foi iniciado apenas em julho de 2010 (FORTALEZA, 2013), faltando cerca de seis meses para o encerramento do prazo inicial dado pelo MCidades, que era dezembro de 2010. Posteriormente o prazo foi prorrogado e a elaboração do PLHISFor foi encerrada no final de 2012, tendo sido realizada uma rápida revisão em janeiro de $2013^{53}$.

53 Em 2016, o PLHISFor passou por um processo de revisão no âmbito do Plano Estratégico Fortaleza 2040, conduzido pelo Instituto de Planejamento de Fortaleza (IPLANFOR). Contudo este processo de 
O PLHISFor identificou a existência de 856 assentamentos precários (Mapa 14), que abrangem quase $35 \%$ do total dos domicílios e mais de $41 \%$ da população de Fortaleza (FORTALEZA, 2016, p. 52). Desse número total de assentamentos, 634 foram classificados como favelas, equivalendo a 74\%. Apresentamos estes números para dar uma noção do avanço do processo de favelização, que persistiu, mesmo com a atuação da HABITAFOR.

\section{Mapa 14 - Assentamentos precários em Fortaleza (2012)}

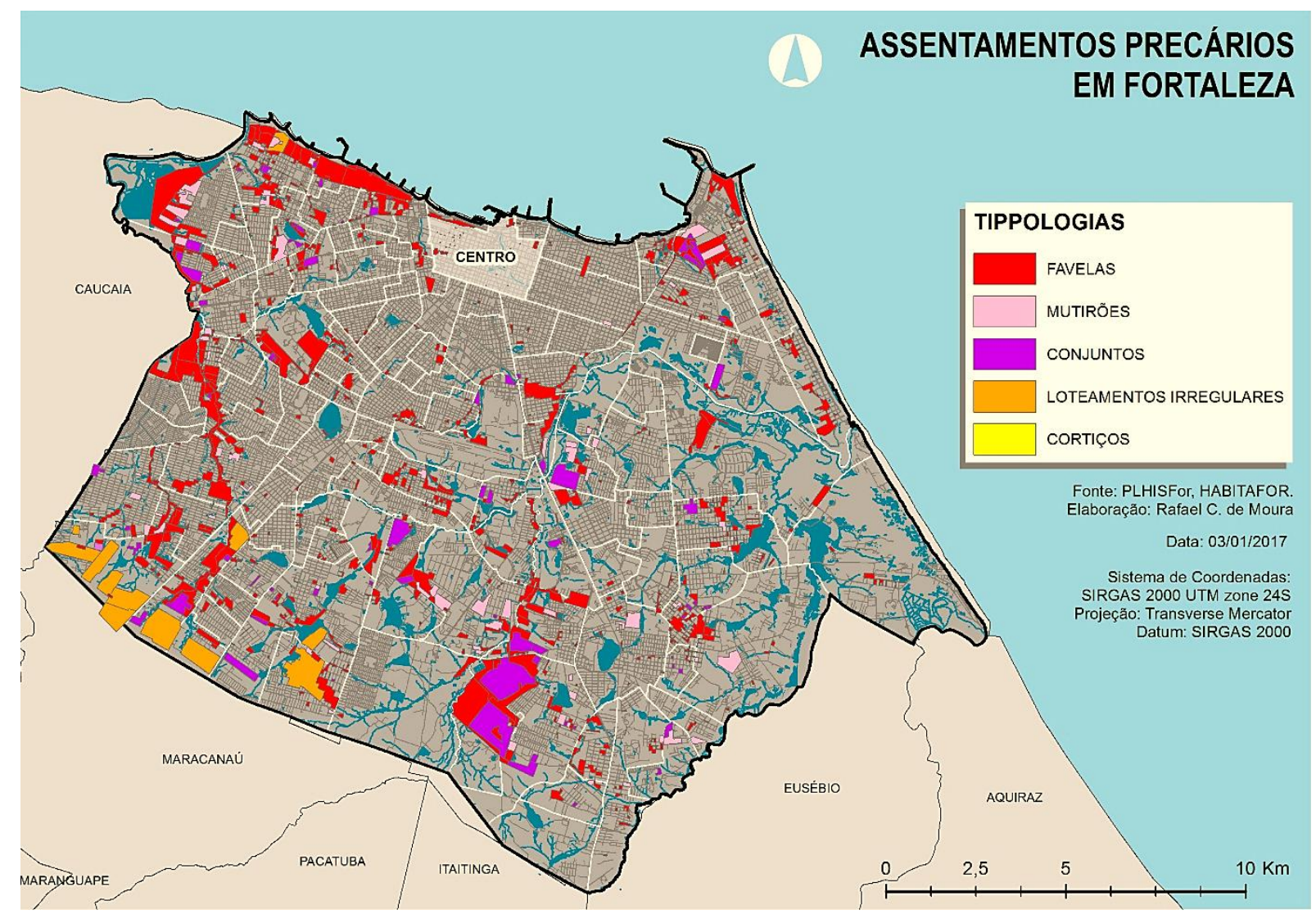

Fonte: PLHISFor (FORTALEZA, 2013), elaboração do autor

Em uma análise sobre o papel desempenhado pela HABITAFOR na última década, Pequeno (2008) destaca como pontos positivos e negativos:

Resgate de recursos para o desenvolvimento institucional, reabilitação do centro para fins residenciais, regularização fundiária de conjuntos habitacionais foram ações positivas postas em andamento. Todavia, alguns problemas são rapidamente detectados. A ausência de processo de planejamento associada à dispersão das ações por diversas secretarias e à corrida desenfreada pela captação de recursos, os quais eram confirmados ainda que para projetos deficientes; a construção da governabilidade através de coalizões

revisão se fez demasiadamente apressado e nem de longe contou com a mesma participação popular que ocorreu no processo de elaboração do plano em 2010. 
políticas impedindo avanços na gestão participativa; lentidão nos processos e retrocessos técnicos; falta de diálogos inter-setoriais e dissociação da política habitacional junto à política urbana, fazem com que a favelização aumente a sua intensidade, levando vantagem em relação às respostas oferecidas pelas políticas públicas.

Por sua vez Gondim destaca que a opção preferencial da HABITAFOR pela remoção de moradores de favelas deixou a desejar, tanto qualitativamente, quando quantitativamente, tendo em vista que o alto preço dos terrenos relegou mais uma vez as áreas de reassentamento a uma localização periférica (Mapa 15). Apesar da autora considerar não ser possível dizer que houve propriamente uma decisão já que "a alternativa da urbanização com permanência dos moradores revelou-se demasiadamente complexa, ante a falta de experiência local e as exigências de outros setores encarregados do controle urbanístico e ambiental" (GONDIM, 2013, p. 161).

Mapa 15 - Intervenções trabalhadas pela HABITAFOR entre 2003 e 2012

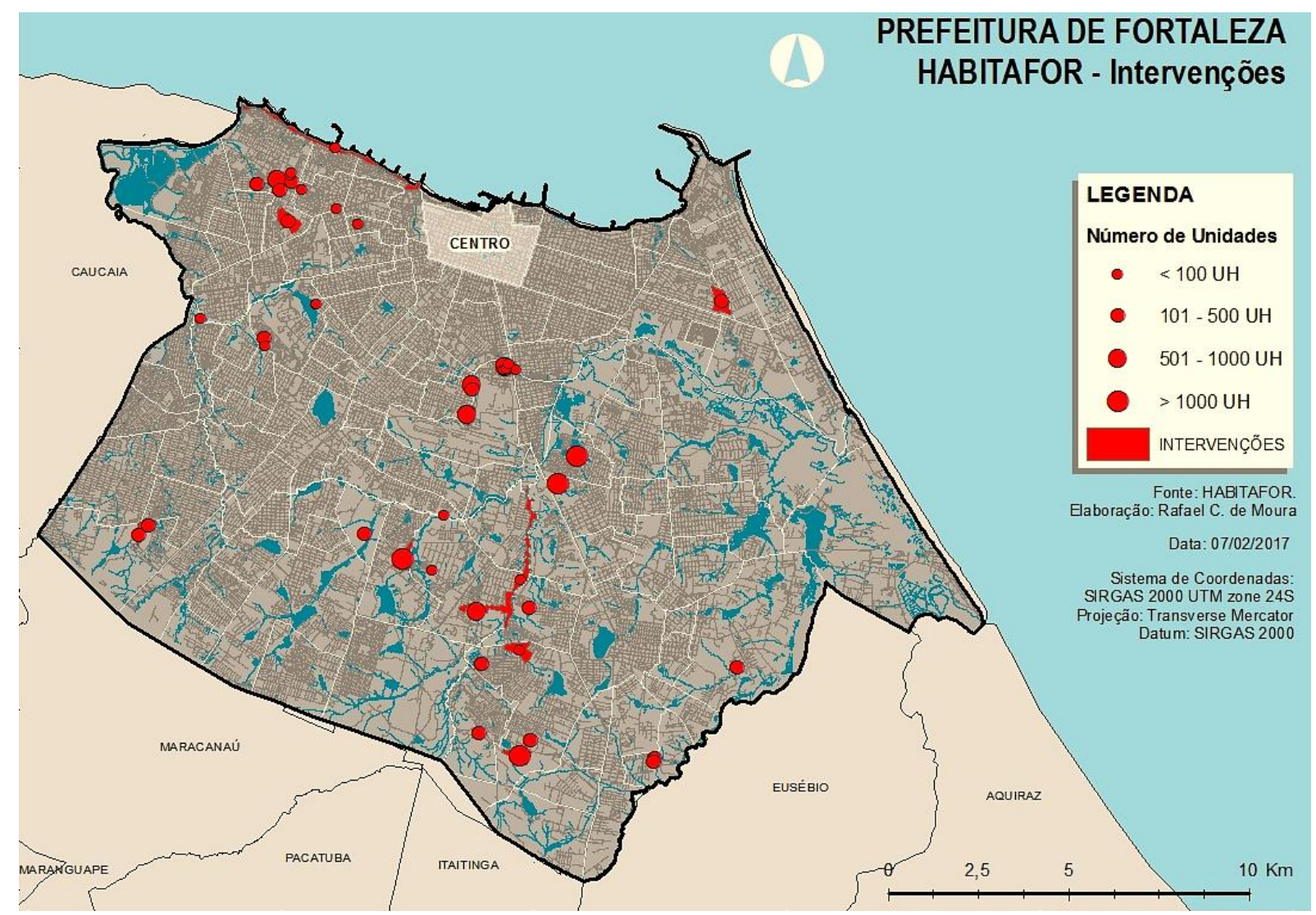

Fonte: HABITAFOR

Ao falarem das dificuldades de aprovação dos projetos da HABITAFOR nos órgãos municipais, nos Bombeiros e nas concessionárias de serviços urbanos, Bisio (2016), Hatsue (2016) e Almeida (2016), corroboram a afirmação de Gondim. 
Destacamos ainda que os subsídios concedidos pela nova política do MCidades permitiram que as unidades da HABITAFOR fossem cedidas gratuitamente, o que constituiu um significativo diferencial, ao compararmos à política do $\mathrm{BNH}$, quando as unidades eram vendidas (GONDIM, 2013). Contudo, isso acarretava algumas limitações aos moradores e dificuldades ao órgão:

São proibidas modificações nas fachadas, nas unidades habitacionais
ou nos blocos de apartamentos, a não ser com autorização da
Habitafor. Os beneficiários também não podem negociar suas
moradias (alugar, ceder ou vender), que Ihes são concedidas
gratuitamente, mediante concessão de direito real de uso; admite-se
apenas a troca, por intermédio da Habitafor. Esta, porém, tem tido
dificuldade de controlar o uso e a ocupação dos novos assentamentos.
São frequentes as intervenções dos moradores nas áreas de uso
comum, seja ajardinando o terreno em frente à moradia, seja
apropriando-se de espaços livres (GONDIM, 2013, p. 159).

Por fim, a participação dos moradores na definição dos projetos se restringia a apresentações das propostas à comunidade, com a incorporação de alguns poucos elementos, quando possível (ALMEIDA, 2016; BISIO, 2016; CARNEIRO, 2016 e HATSUE, 2016), não havendo interferência em questões cruciais, como a localização dos conjuntos.

A mudança de gestão em 2013 levou outro grupo político ao poder em Fortaleza. Curiosamente, as articulações políticas conduziram novamente Olinda Marques e Eliana Gomes à direção da HABITAFOR, como veremos no item a seguir.

\subsection{A criação da Secretaria Municipal do Desenvolvimento Habitacional de Fortaleza (HABITAFOR)}

As eleições de 2012 trouxeram mudanças para a gestão municipal. Inácio Arruda lançou-se candidato a prefeito pelo PC do B, rompendo a aliança de oito anos com o PT. O governador do estado, Cid Gomes, então no PSB, que havia apoiado Luizianne Lins na campanha pela reeleição em 2008, também decide romper a aliança com o PT e lançar como candidato o presidente da Assembleia Legislativa à época, Roberto Cláudio, que sai vitorioso no pleito. 
O apoio de Inácio Arruda à Roberto Cláudio no segundo turno garantiu ao PC do B uma participação na gestão. É assim que Eliana Gomes e Olinda Marques retornam à HABITAFOR em 2013, desta vez com Eliana na presidência da fundação e Olinda assumindo o cargo de secretária executiva do órgão, criado na pequena reforma administrativa realizada pelo novo prefeito ainda em 2013. Segundo Marques (2016), a situação em que se encontrava a HABITAFOR era um desastre. Obras paralisadas, algumas delas ocupadas pela população mesmo sem que houvessem sido concluídas.

No cenário nacional, a política habitacional do Ministério das Cidades foi dominada pelo Programa Minha Casa Minha Vida. Nesse contexto, a HABITAFOR deixa de ter como função a elaboração de projetos de intervenção, ocorrendo uma grande redução na sua equipe técnica, que passa a atuar como apoio às empreiteiras na implementação do PMCMV, especialmente no processo de licenciamento junto aos órgãos municipais responsáveis (AQUINO, PAIVA e BRAGA, 2016).

Com a reforma administrativa de 2014, a fundação é transformada em Secretaria Municipal do Desenvolvimento Habitacional de Fortaleza, mantendo a sigla pela qual ficou conhecida. ${ }^{54}$ Enquanto aparentemente a reforma fortalece a HABITAFOR, elevando-a ao status de secretaria municipal, contraditoriamente, a função de regulamentação das Zonas Especiais de Interesse Social (ZEIS), estabelecidas no Plano Diretor de 2009, é atribuída ao Instituto de Planejamento de Fortaleza (IPLANFOR), reduzindo as responsabilidades da HABITAFOR.

Com relação aos projetos que já vinham sendo desenvolvidos, buscou-se a migração de parte deles para o PMCMV (Mapa 16) e a redução das metas no que se refere à urbanização, em negociações com a CEF e o MCidades (AQUINO, 2016 e MARQUES, 2016). Os projetos, mesmo os incluídos no PAC, que possuíam áreas para reassentamento cujas obras não haviam iniciado, ou que até haviam iniciado, mas ainda estavam em fase inicial, tiveram seus terrenos disponibilizados em chamadas públicas para empresas interessadas em promover empreendimentos do Minha Casa Minha Vida (AQUINO, PAIVA e BRAGA, 2016). Assim, rapidamente se

\footnotetext{
${ }^{54}$ Lei Complementar ํㅜ 176, de 29 de dezembro de 2014.
} 
descontruiu o pouco que havia sido elaborado de política habitacional no município, ficando praticamente restrita apenas à provisão habitacional.

Mapa 16 - Projetos da HABITAFOR transformados em MCMV

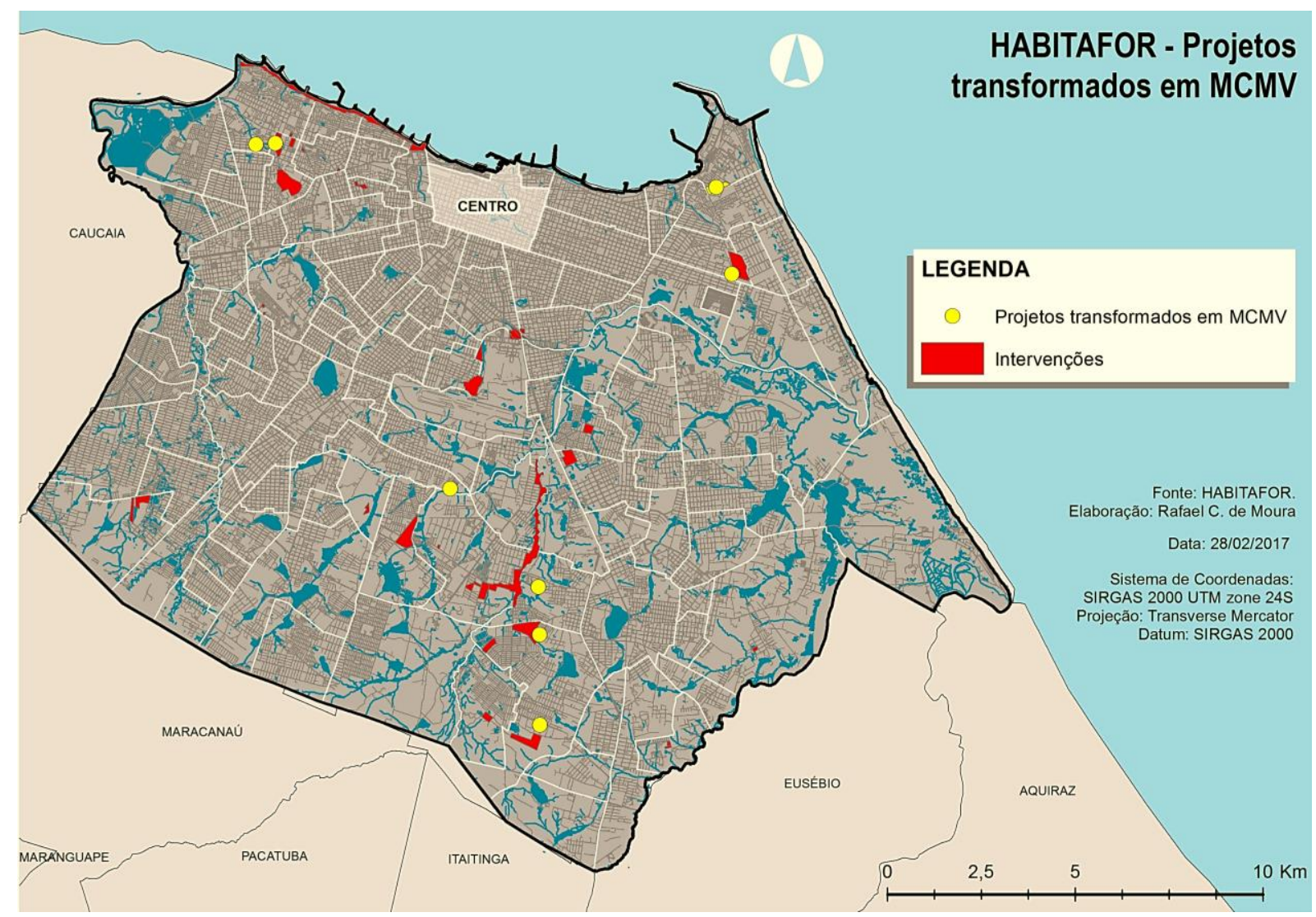

Fonte: HABITAFOR, elaboração do autor 


\section{CAPÍTULO 02 - A PRODUÇÃO DE HABITAÇÃO DE INTERESSE SOCIAL PELO MUNICÍPIO DE FORTALEZA E AS DIRETRIZES DO MINISTÉRIO DAS CIDADES}


Vimos no capítulo anterior que, a partir de 2003, com a criação do Ministério das Cidades, houve um processo de reestruturação do setor habitacional a nível federal, após um longo período de desarticulação das ações, desde a extinção do BNH, em 1986. A instituição do SNHIS e do FNHIS, a reformulação de antigos programas habitacionais e a criação de novos, a elaboração do PlanHab, dentre outras medidas, forneceram um arcabouço de diretrizes para a concepção das intervenções, seja de urbanização de assentamentos precários ou de provisão de habitação de interesse social. Neste capítulo, apresentaremos uma caracterização das intervenções realizadas pela HABITAFOR até 2012, bem como uma análise do reflexo das diretrizes concebidas pelo MCidades para a implementação de seus programas sobre estas intervenções.

Para realizar a caracterização das intervenções, recorremos à coleta de informações junto à HABITAFOR, sobretudo através de seus projetos. Buscamos complementar os dados com entrevistas semiestruturadas realizadas com técnicos e gestores do órgão, inclusive com alguns que já não trabalham mais no órgão. Adotamos três categorias para classificação: tipo de intervenção, porte da intervenção e tipologia habitacional.

$\mathrm{Na}$ análise do reflexo das diretrizes do MCidades sobre as intervenções, lançamos mão de levantamento bibliográfico, que se constituiu basicamente de legislação e manuais programáticos. As diretrizes encontradas foram reunidas de acordo com as temáticas abordadas, configurando quatro grupos: 1. Diretrizes que se relacionam à política urbana; 2 . Diretrizes que se relacionam à intervenção e seu entorno; 3 . Diretrizes relacionadas à edificação das unidades habitacionais; e 4. Diretrizes relacionadas à definição dos beneficiários dos programas e intervenções. $O$ resultado foi a elaboração de um quadro com uma síntese das principais diretrizes que deveriam orientar a atuação de municípios e estados interessados em realizar ações habitacionais com recursos captados por meio das sistemáticas do MCidades (Quadro 8). 


\subsection{Breve caracterização das intervenções da HABITAFOR até 2012}

No primeiro capítulo deste trabalho, vimos que as intervenções implementadas pela HABITAFOR até 2012 foram concebidas em sua maioria durante a gestão de Olinda Marques no órgão, que durou até meados de $2009^{55}$.

Em um primeiro momento, entre 2005 e 2006, quando os recursos do governo federal ainda estavam começando a ser disponibilizados, foram desenvolvidos projetos de menor porte, devido à necessidade de maior aporte de recursos por parte do governo municipal. Por esta razão, estes projetos tinham maior foco na questão da provisão habitacional do que na urbanização de assentamentos precários. Consideramos intervenções características desse período: Anita Garibaldi, Autran Nunes, Bárbara de Alencar I, Jana Barroso, Marrocos, Planalto Pici, Socorro Abreu e Rosa Luxemburgo. Nesse período, também foi dada continuidade a projetos oriundos da gestão Juraci, através do PHBB, Lagoa do Opaia / Planalto Universo e Maravilha.

A partir de 2007, a estruturação da HABITAFOR, em termos de profissionais e equipamentos, e a ampliação da disponibilidade de recursos pelo governo federal, a serem captados através das Sistemáticas do Ministério das Cidades ${ }^{56}$, possibilitaram que as intervenções passassem a ter maior porte. A questão da urbanização de assentamentos precários adquire maior importância nas intervenções concebidas. É possível perceber, nesse período, que passa a ocorrer uma desvinculação das intervenções em relação à hierarquização das áreas de risco do PEMAS e a definição política passa a exercer maior influência na seleção das áreas a serem trabalhadas. São projetos característicos desse período: Açude João Lopes, Lagoa do Urubu, Lagoa do Papicu, São Cristóvão / Campo Estrela, Vila do Mar, Urucutuba

\footnotetext{
${ }^{55}$ Como explicado no capítulo anterior, as intervenções Lagoa do Opaia e Maravilha foram concebidas ainda na gestão de Juraci Magalhães (1995-2002). Com as obras já concluídas do Planalto Universo, o reassentamento das famílias que ocupavam as margens da Lagoa do Opaia, coube à equipe da HABITAFOR na gestão Luizianne (2005-2012) concluir as obras de urbanização e implementar o processo de regularização fundiária. Na Maravilha, a partir de 2005, foram necessárias alterações nos projetos, bem como realização da licitação e da execução. Além disso, relembramos que as intervenções Vila do Mar, Rosalina e PREURBIS - Cocó, apesar de concebidas fora da HABITAFOR, em outros órgãos, acabaram com a fiscalização das obras, ou o trabalho social, ou o processo de regularização fundiária, implementados por ela.

${ }^{56}$ Principalmente após o lançamento do Programa de Aceleração do Crescimento - PAC, pelo qual a HABITAFOR conseguiu captar recursos para intervenções como: Lagoa do Urubu, Lagoa do Papicu, São Cristóvão / Campo Estrela, Açude João Lopes e Vila do Mar.
} 
É preciso ressaltar que essa periodização não é rígida. Na prática, é possível identificar intervenções que fugiram às características predominantes nos dois períodos. Por exemplo, a intervenção Lagoa da Zeza e Vila Cazumba, de grande porte, foi concebida no primeiro momento. Assim como é possível encontrar projetos de menor porte no segundo período, como Casa e Renda, Itaperussu e Sabiá.

Para a caracterização das intervenções, estabelecemos três categorias de classificação: Tipo de Intervenção, Porte da Intervenção e Tipologia Habitacional. A seguir, apresentaremos cada categoria e os resultados encontrados.

\subsubsection{Tipo da Intervenção}

A classificação que utilizamos, referente ao "Tipo da Intervenção", baseia-se na mesma adotada pelo Ministério das Cidades, que aponta 4 tipos de intervenção: Urbanização Simples, Urbanização Complexa, Reassentamento e Remanejamento (DENALDI, 2008). Os tipos de intervenção podem aparecer isoladamente ou associados em cada projeto.

A Urbanização Simples é uma intervenção voltada para assentamentos pouco adensados, que apresentem um traçado mais regular e que não necessitem de obras complexas de infraestrutura, ou geotécnicas. Por sua vez, a Urbanização Complexa é voltada para assentamentos com maior grau de adensamento, que precisam de um maior número de remoções, apresentam traçado irregular, ou necessidade de execução de obras complexas de drenagem urbana ou geotécnicas (DENALDI, 2008).

O Remanejamento se trata de uma intervenção em que é possível a manutenção da população moradora do assentamento precário, ou de grande parte, na mesma área de origem, após a substituição das moradias e do tecido urbano, mesmo que haja um deslocamento temporário das famílias. No caso do Reassentamento, a produção das novas unidades habitacionais para os moradores removidos do assentamento precário, mesmo que de diferentes tipos (apartamentos, casas, lotes urbanizados), é realizada em área distinta, mesmo que próxima (DENALDI, 2008). Para as intervenções aqui apresentadas apenas como Remanejamento ou Reassentamento, queremos dizer que não houve a urbanização da área de origem das famílias. 
Além dos quatro tipos citados acima, neste trabalho acrescentamos um quinto, a Provisão Habitacional, para diferenciar das intervenções de reassentamento ou remanejamento que atenderam a demandas específicas, de um assentamento precário, ou mais. Referimo-nos àquelas intervenções de construção de unidades habitacionais para receber famílias de origens diversas, como de abrigos públicos, ou do cadastro de demandas espontâneas da HABITAFOR. Neste, constavam famílias que haviam se dirigido ao órgão de maneira individual para solicitar uma unidade habitacional e fornecido seus dados socioeconômicos através de um instrumento chamado Boletim de Informações Cadastrais (BIC), ou famílias encaminhadas por órgãos como os Conselhos Tutelares ou o Ministério Público, que incluem pessoas em situação de extrema pobreza, mulheres vítimas de violência doméstica ou sexual, entre outros (ARAUJO, 2013).

De posse das informações sobre as intervenções da HABITAFOR e da classificação dos tipos de intervenção, elaboramos a Tabela 1, na qual é possível observar que a maioria se enquadra no tipo Urbanização Complexa com Reassentamento. Em termos percentuais (coluna F) e absolutos (coluna D), o maior número de unidades habitacionais produzidas se enquadra neste tipo de intervenção, 76,76\% e 3.139 unidades, respectivamente. Ressaltamos que nossa análise se restringe ao quantitativo de unidades, não foram consideradas a dimensão das obras de urbanização e infraestrutura para o cálculo do percentual executado.

Quando comparamos o percentual de unidades habitacionais executadas em cada tipo de intervenção (coluna E), o desempenho das intervenções tipo Urbanização Complexa com Reassentamento $(41,53 \%)$ é menor do que as do tipo Provisão Habitacional (60,00\%), Remanejamento (100\%) e Reassentamento $(57,27 \%)$. As dificuldades enfrentadas pelas intervenções do tipo Urbanização Complexa, que exigem o envolvimento de diversas instâncias de gestão e requerem uma relação mais afinada entre poder público e população, pode ser uma explicação para a redução no desempenho com relação à execução de unidades habitacionais ${ }^{57}$.

\footnotetext{
${ }^{57}$ Como exemplo dessas dificuldades, podemos citar o caso da intervenção Lagoa do Papicu, no qual questionamentos judiciais sobre a desapropriação de um bar existente na área adquirida para ser o reassentamento atrasou o andamento das obras em seis meses (O ESTADO CE, 2009).
} 
Tabela 1 - Classificação das intervenções da HABITAFOR conforme o Tipo

\begin{tabular}{|c|c|c|c|c|c|c|c|}
\hline TIPO & INTERVENÇÃO & $\begin{array}{c}\text { UH } \\
\text { PREV. } \\
\text { (A) }\end{array}$ & $\begin{array}{c}\text { UH } \\
\text { PREV. / } \\
\text { TIPO (B) }\end{array}$ & $\begin{array}{c}\text { UH } \\
\text { EXEC. } \\
\text { (C) }\end{array}$ & $\begin{array}{l}\text { UH EXEC. } \\
\text { / TIPO } \\
\text { (D) }\end{array}$ & $\begin{array}{c}\% \text { UH } \\
\text { EXEC./ } \\
\text { TIPO (E) }\end{array}$ & $\begin{array}{c}\% \text { UH } \\
\text { EXEC. } \\
\text { TOTAL (F) }\end{array}$ \\
\hline \multirow{4}{*}{$\begin{array}{l}\text { Provisão } \\
\text { Habitacional }\end{array}$} & Casa e Renda & 20 & \multirow{4}{*}{260} & 20 & \multirow{4}{*}{156} & \multirow{4}{*}{$60,00 \%$} & \multirow{4}{*}{$3,81 \%$} \\
\hline & Itaperussu & 88 & & 0 & & & \\
\hline & Planalto Pici & 80 & & 80 & & & \\
\hline & Sabiá & 72 & & 56 & & & \\
\hline Remanejamento & Autran Nunes & 3 & 3 & 3 & 3 & $100,00 \%$ & $0,07 \%$ \\
\hline \multirow{7}{*}{ Reassentamento } & Anita Garibaldi & 20 & & 20 & \multirow{7}{*}{713} & \multirow{7}{*}{$57,27 \%$} & \multirow{7}{*}{$17,43 \%$} \\
\hline & Bárbara de Alencar I & 104 & & 104 & & & \\
\hline & Bárbara de Alencar II & 284 & & 100 & & & \\
\hline & Jana Barroso & 272 & 1.245 & 256 & & & \\
\hline & Rosa Luxemburgo & 171 & & 171 & & & \\
\hline & Socorro Abreu & 62 & & 62 & & & \\
\hline & Urucutuba & 332 & & 0 & & & \\
\hline $\begin{array}{l}\text { Urbanização } \\
\text { Simples }\end{array}$ & Cidade de Deus & 0 & 0 & 0 & 0 & - & - \\
\hline Urbanização & & & & & & & \\
\hline $\begin{array}{l}\text { Simples com } \\
\text { Reassentamento }\end{array}$ & Açude João Lopes & 80 & 80 & 80 & 80 & $100,00 \%$ & $1,96 \%$ \\
\hline \multirow{11}{*}{$\begin{array}{l}\text { Urbanização } \\
\text { Complexa com } \\
\text { Reassentamento }\end{array}$} & $\begin{array}{l}\text { Lagoa da Zeza e Vila } \\
\text { Cazumba / Maria Tomásia }\end{array}$ & 1.128 & \multirow{10}{*}{7.558} & 1.126 & \multirow{10}{*}{3.139} & \multirow{10}{*}{$41,53 \%$} & \multirow{10}{*}{$76,73 \%$} \\
\hline & $\begin{array}{l}\text { Lagoa do Opaia / Planalto } \\
\text { Universo }\end{array}$ & 504 & & 504 & & & \\
\hline & Lagoa do Papicu & 488 & & 92 & & & \\
\hline & Lagoa do Urubu & 188 & & 44 & & & \\
\hline & Maravilha & 606 & & 606 & & & \\
\hline & Marrocos & 147 & & 72 & & & \\
\hline & Preurbis - Cocó & 816 & & 0 & & & \\
\hline & Rosalina & 1.807 & & 412 & & & \\
\hline & $\begin{array}{l}\text { São Cristóvão / Campo } \\
\text { Estrela }\end{array}$ & 440 & & 19 & & & \\
\hline & Vila do Mar & 1.434 & & 264 & & & \\
\hline & TOTAL & 9.146 & & 4.091 & & & \\
\hline
\end{tabular}

Fonte: HABITAFOR, elaboração do autor

\subsubsection{Porte da Intervenção}

Em nossa pesquisa, para a caracterização das intervenções quanto ao Porte, levamos em consideração apenas o número de unidades habitacionais previsto em cada projeto, de forma a estabelecer um parâmetro de comparação entre intervenções de tipos diferentes, como visto no item anterior. Assim, foram desconsideradas as áreas que receberiam apenas obras de urbanização, que em alguns casos abrange grande parte da intervenção, especialmente naquelas intervenções que envolvem recursos hídricos, como lagoas e canais, etc. 
Não há um consenso estabelecido entre os teóricos sobre a quantidade de unidades habitacionais necessárias para classificar o porte de um conjunto habitacional (CARNEIRO, 2013). Para Gondim (2013), as intervenções da HABITAFOR são consideradas pequenas, tendo em vista uma tipologia de classificação elaborada para a política habitacional do $\mathrm{BNH}$, que foi marcada por grandes conjuntos periféricos ${ }^{58}$.

A Lei de Uso e Ocupação do Solo (LUOS) de Fortaleza, no parágrafo $2^{\circ}$, do artigo 198, estabelece que Conjuntos Habitacionais de Interesse Social com mais de 300 unidades deverão ser analisados como Projeto Especial. Devido a seu porte, conjuntos dessa dimensão deveriam passar por uma análise específica para sua aprovação.

A limitação dos contratos do PMCMV a 500 unidades habitacionais (UH), estabelecida em sua primeira fase (PEQUENO e ROSA, 2016), foi considerada um outro indicativo para a definição do porte. Podemos apreender dessa limitação que, a partir desse quantitativo, os conjuntos teriam maior impacto no tecido urbano, devendo-se ter maiores cuidados na sua implantação, especialmente relacionados à oferta de serviços públicos, como nas áreas de saúde e educação.

Tendo em mente essas reflexões, apoiamo-nos em Carneiro (2013) para estabelecer como critério de classificação: PEQUENO, para intervenções com até $100 \mathrm{UH}$; MÉDIO, para aquelas que tenham entre 101 e $500 \mathrm{UH}$; GRANDE, para aquelas que tenham entre 501 e 1000 UH; e MUITO GRANDE, para as intervenções com mais de $1000 \mathrm{UH}$.

Desta forma, elaboramos a Tabela 2, na qual podemos observar que a grande maioria das intervenções da HABITAFOR possui um porte Pequeno ou Médio. Contudo, quando somamos os percentuais de unidades habitacionais previstas (coluna $\mathrm{C}$ ), nas intervenções destes portes, percebemos que todas elas juntas atingiriam somente $31,17 \%$ das unidades previstas para construção, cerca de um terço do total. Enquanto apenas as seis intervenções consideradas Grande e Muito Grande seriam

\footnotetext{
${ }^{58}$ Para conhecer mais sobre os grandes conjuntos do BNH em Fortaleza, ver Aragão (2010) e Máximo
} (2012). 
responsáveis por dois terços das unidades a serem produzidas, demonstrando seu peso na política habitacional.

Tabela 2 - Classificação das Intervenções da HABITAFOR conforme o Porte

\begin{tabular}{|c|c|c|c|c|}
\hline PORTE & INTERVENÇÃO & $\begin{array}{l}\text { UH PREV. } \\
\text { (A) }\end{array}$ & $\begin{array}{l}\text { UH PREV. I } \\
\text { PORTE (B) }\end{array}$ & $\begin{array}{l}\text { \%UH PREV. } \\
\text { /PORTE (C) }\end{array}$ \\
\hline & Açude João Lopes & 80 & & \\
\hline & Anita Garibaldi & 20 & & \\
\hline & Autran Nunes & 3 & & \\
\hline & Casa e Renda & 20 & & \\
\hline \multirow[t]{9}{*}{ Pequeno } & Cidade de Deus & 0 & 425 & $4,65 \%$ \\
\hline & Itaperussu & 88 & & \\
\hline & Planalto Pici & 80 & & \\
\hline & Sabiá & 72 & & \\
\hline & Socorro Abreu & 62 & & \\
\hline & Bárbara de Alencar I & 104 & & \\
\hline & Bárbara de Alencar II & 284 & & \\
\hline & Jana Barroso & 272 & & \\
\hline & Lagoa do Papicu & 488 & & \\
\hline \multirow[t]{6}{*}{ Médio } & Lagoa do Urubu & 188 & 2.426 & $26,53 \%$ \\
\hline & Marrocos & 147 & & \\
\hline & Rosa Luxemburgo & 171 & & \\
\hline & São Cristóvão / Campo Estrela & 440 & & \\
\hline & Urucutuba & 332 & & \\
\hline & Lagoa do Opaia / Planalto Universo & 504 & & \\
\hline \multirow[t]{3}{*}{ Grande } & Maravilha & 606 & 1.926 & $21,06 \%$ \\
\hline & Preurbis - Cocó & 816 & & \\
\hline & Lagoa da Zeza e Vila Cazumba / Maria Tomásia & 1.128 & & \\
\hline \multirow[t]{3}{*}{ Muito Grande } & Rosalina & 1.807 & 4.369 & $47,77 \%$ \\
\hline & Vila do Mar & 1.434 & & \\
\hline & TOTAL & 9.146 & & $100 \%$ \\
\hline
\end{tabular}

Fonte: HABITAFOR, elaboração do autor

\subsubsection{Quanto à Tipologia Habitacional}

Nas intervenções realizadas pela HABITAFOR entre 2003 e 2012, houve pouca variação das tipologias habitacionais utilizadas. De modo geral, foi adotada a alvenaria estrutural como técnica construtiva, resultando na proibição de execução de modificações na fachada, ou na planta, pelos moradores, sem a autorização da HABITAFOR (GONDIM, 2013).

Apesar da proibição, é possível constatar diversas alterações nas unidades (Figura 1). Entre as mais simples, encontramos mudanças de esquadrias ou instalação de grades nas portas e janelas. Dentre as mais complexas, encontram-se acréscimos às edificações, os conhecidos "puxadinhos", como a ampliação das unidades, ou a 
construção de garagens, bastante frequentes em conjuntos habitacionais (REIS e LAY, 2010).

Figura 1 - Construções irregulares nas intervenções Maravilha (esq.) e Açude João Lopes (dir.)

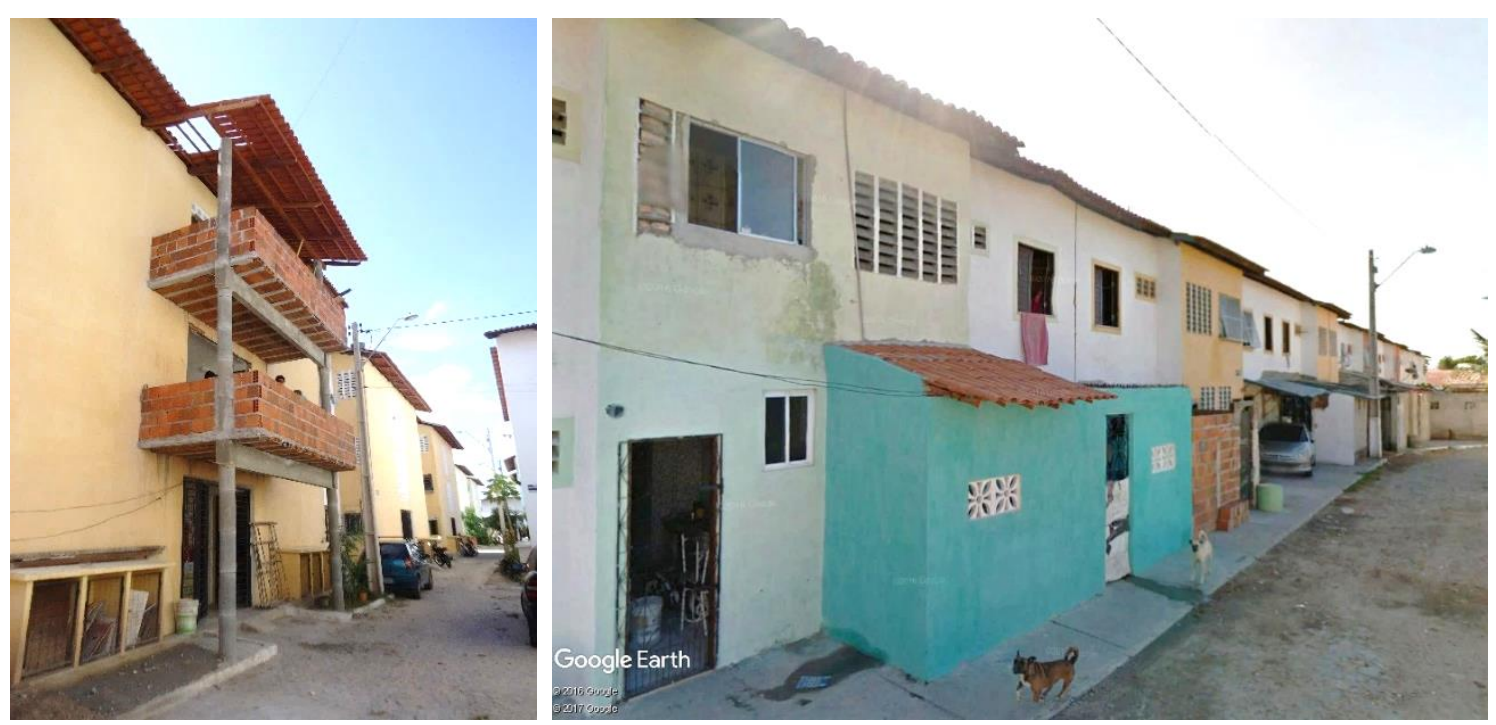

Fonte: HABITAFOR (2011) e Google Earth (2015)

Segundo Gondim (2013, p. 158), “As moradias ofertadas pela Habitafor, tipicamente, localizam-se em unidades duplex geminadas, tendo sala, cozinha e dois quartos, construídas em blocos separados por ruas internas". Em algumas tipologias havia uma pequena área de serviço integrada à cozinha, na qual cabia apenas um tanque para lavar roupas. Quanto ao dimensionamento, as unidades apresentavam uma variação de área útil entre $30 \mathrm{~m}^{2}$, no caso das casas de um quarto do projeto Rosalina ${ }^{59}$, e $53 \mathrm{~m}^{2}$ nos apartamentos de três quartos do conjunto Socorro Abreu.

Dividimos as unidades habitacionais utilizadas nas intervenções da HABITAFOR podem em: Unifamiliar, com casas térreas; Térreo+1 $(T+1)$, bloco de apartamentos com pavimento térreo e um pavimento superior; Térreo+2 $(T+2)$, para blocos de apartamentos com pavimento térreo e dois pavimentos superiores; e Térreo+3 $(T+3)$, para blocos de apartamentos com pavimento térreo e três pavimentos superiores. Os blocos de apartamentos foram utilizados tanto de forma isolada, quanto associada, constituindo fileiras ou blocos maiores, como na Maravilha. De acordo com o emprego das unidades em cada intervenção, estabelecemos a seguinte classificação para as

\footnotetext{
${ }^{59}$ A Rosalina foi a única intervenção realizada pela prefeitura de Fortaleza no período pós MCidades que contou com unidades habitacionais de apenas um quarto, lembrando os mutirões implementados pela COMHAB na década de 1990, com unidades tipo embrião.
} 
Tipologias: Unifamiliar; $T+1$; $T+1$ e Unifamiliar; $T+2$; $T+2$ e Unifamiliar; e $T+3$, que resultou na elaboração da Tabela 3.

Tabela 3 - Classificação das Intervenções da HABITAFOR conforme a Tipologia Habitacional

\begin{tabular}{|c|c|c|c|c|c|c|c|c|}
\hline TIPOLOGIA & INTERVENÇÃO & $\begin{array}{l}\text { UH } \\
\text { PREV. } \\
\text { (A) }\end{array}$ & $\begin{array}{l}\text { UH } \\
\text { PREV. } \\
\text { /TIPOL. } \\
\text { (B) }\end{array}$ & $\begin{array}{c}\% \\
\text { PREV. } \\
\text { TOTAL } \\
\text { (C) }\end{array}$ & $\begin{array}{c}\text { UH } \\
\text { EXEC. } \\
\text { (D) }\end{array}$ & $\begin{array}{l}\text { UH } \\
\text { EXEC. } \\
\text { /TIPOL. } \\
\text { (E) }\end{array}$ & $\begin{array}{l}\% \\
\text { EXEC. } \\
\text { /TIPOL. } \\
\text { (F) }\end{array}$ & $\begin{array}{c}\% \\
\text { EXEC. } \\
\text { TOTAL } \\
\text { (G) }\end{array}$ \\
\hline \multirow{3}{*}{ Unifamiliar } & Autran Nunes & 3 & \multirow{3}{*}{1.278} & \multirow{3}{*}{$13,97 \%$} & 3 & \multirow{3}{*}{1.201} & \multirow{3}{*}{$93,97 \%$} & \multirow{3}{*}{$29,36 \%$} \\
\hline & $\begin{array}{l}\text { Lagoa da Zeza e Vila } \\
\text { Cazumba / Maria Tomásia }\end{array}$ & 1.128 & & & 1.126 & & & \\
\hline & Marrocos & 147 & & & 72 & & & \\
\hline \multirow{12}{*}{$T+1$} & Açude João Lopes & 80 & \multirow{12}{*}{2.230} & \multirow{12}{*}{$24,38 \%$} & 80 & \multirow{12}{*}{1.238} & \multirow{12}{*}{$55,52 \%$} & \multirow{12}{*}{$30,26 \%$} \\
\hline & Anita Garibaldi & 20 & & & 20 & & & \\
\hline & Bárbara de Alencar I & 104 & & & 104 & & & \\
\hline & Casa e Renda & 20 & & & 20 & & & \\
\hline & Itaperussu & 88 & & & 0 & & & \\
\hline & Jana Barroso & 272 & & & 256 & & & \\
\hline & $\begin{array}{l}\text { Lagoa do Opaia / Planalto } \\
\text { Universo }\end{array}$ & 504 & & & 504 & & & \\
\hline & Lagoa do Papicu & 488 & & & 92 & & & \\
\hline & Lagoa do Urubu & 188 & & & 44 & & & \\
\hline & Sabiá & 72 & & & 56 & & & \\
\hline & Socorro Abreu & 62 & & & 62 & & & \\
\hline & Urucutuba & 332 & & & 0 & & & \\
\hline \multirow{3}{*}{$\begin{array}{l}\mathrm{T}+1 \mathrm{e} \\
\text { Unifamiliar }\end{array}$} & Bárbara de Alencar II & 284 & \multirow{3}{*}{895} & \multirow{3}{*}{$9,79 \%$} & 100 & \multirow{3}{*}{290} & \multirow{3}{*}{$32,40 \%$} & \multirow{3}{*}{$7,09 \%$} \\
\hline & Rosa Luxemburgo & 171 & & & 171 & & & \\
\hline & $\begin{array}{l}\text { São Cristóvão / Campo } \\
\text { Estrela }\end{array}$ & 440 & & & 19 & & & \\
\hline \multirow{3}{*}{$\mathrm{T}+2$} & Maravilha & 606 & \multirow{3}{*}{2.856} & \multirow{3}{*}{$31,23 \%$} & 606 & \multirow{3}{*}{870} & \multirow{3}{*}{$30,46 \%$} & \multirow{3}{*}{$21,27 \%$} \\
\hline & Preurbis - Cocó & 816 & & & 0 & & & \\
\hline & Vila do Mar & 1.434 & & & 264 & & & \\
\hline $\begin{array}{l}T+2 \mathrm{e} \\
\text { Unifamiliar }\end{array}$ & Rosalina & 1.807 & 1.807 & $19,76 \%$ & 412 & 412 & $22,80 \%$ & $10,07 \%$ \\
\hline \multirow[t]{2}{*}{$T+3$} & Planalto Pici & 80 & 80 & $0,87 \%$ & 80 & 80 & $100,00 \%$ & $1,96 \%$ \\
\hline & TOTAL & 9.146 & & $100 \%$ & 4.091 & & & $100 \%$ \\
\hline
\end{tabular}

Fonte: HABITAFOR, elaboração do autor

Podemos observar que a maioria das intervenções da HABITAFOR adotou a tipologia Unifamiliar ou a $T+1$, somando $48,14 \%$ das unidades previstas nos projetos (coluna B). Quando consideramos apenas o número de unidades executado, esse percentual se eleva para $66,71 \%$ (coluna $G$ ). A tipologia Unifamiliar chama a atenção pelo alto índice de execução (coluna E) de 93,96\% do previsto (coluna B), o que pode ser explicado pelo fato de serem obras mais simples e rápidas. Por sua vez, observamos uma pouca utilização da tipologia $T+3$, mais verticalizada, que permitiria maior adensamento nas intervenções e uma redução nos custos com aquisição de terrenos. A explicação encontrada nos relatos de ex-funcionários da HABITAFOR também se 
relaciona aos custos: uma tipologia mais verticalizada exigira uma obra mais complexa, portanto mais cara e geraria custos condominiais para os moradores, que se procurava reduzir ao mínimo.

\subsection{Análise das Intervenções à luz das Diretrizes do Ministério das Cidades}

No primeiro capítulo deste trabalho, vimos que a Lei $n^{0} 11.124 / 2005$, que instituiu o SNHIS, o FNHIS e seu Conselho Gestor, estabeleceu em seu artigo 12 uma série de requisitos para serem cumpridos por estados e municípios que pretendessem acessar os recursos disponibilizados pelo governo federal através do FNHIS, como a criação da estrutura "CPF", Conselho - Plano - Fundo. Neste item, a pesquisa se relacionará mais especificamente com o inciso $\mathrm{VI}$, do mesmo artigo, que definiu a obrigação de se "observar os parâmetros e diretrizes para concessão de subsídios no âmbito do FNHIS" (BRASIL, 2005, p. s/n). Além da própria lei 11.124/2005, foram consultadas as resoluções do Conselho Gestor do FNHIS (CGFNHIS) de n0 04/2006 (CGFNHIS, 2006) e 09/2007 (CGFNHIS, 2007), que aprovaram as diretrizes das ações programáticas do FNHIS, bem como manuais ${ }^{60}$ para apresentações de propostas dos programas do MCidades.

Os documentos consultados separavam as diretrizes em gerais e específicas, mas, em nosso trabalho, observando as temáticas abordadas, procuramos agrupá-las em quatro grupos: 1. Diretrizes que se relacionam à política urbana; 2 . Diretrizes que se relacionam à intervenção e seu entorno; 3. Diretrizes relacionadas à edificação das unidades habitacionais; e 4. Diretrizes relacionadas à definição dos beneficiários dos programas e intervenções. Foi elaborado um quadro síntese (Quadro 8) que orientou a abordagem de cada grupo nos itens a seguir, nos quais analisamos o rebatimento das diretrizes nas intervenções da HABITAFOR.

\footnotetext{
60 Brasil (2007c, 2007d, 2007e, 2007f, 2012a e 2012b).
} 
Quadro 8 - Síntese das diretrizes programáticas concebidas pelo MCidades

\begin{tabular}{|c|c|c|c|}
\hline POLÍTICA URBANA & $\begin{array}{l}\text { INTERVENÇÂO E } \\
\text { ENTORNO } \\
\end{array}$ & \begin{tabular}{|l|} 
UNIDADES \\
HABITACIONAIS \\
\end{tabular} & BENEFICIÁRIOS \\
\hline $\begin{array}{l}\text { Promoção do ordenamento } \\
\text { territorial das cidades; } \\
\text { Compatibilização com o Plano } \\
\text { Diretor e outros planos setoriais } \\
\text { (habitação, saneamento, } \\
\text { mobilidade, etc.); } \\
\text { Utilização prioritária de áreas não } \\
\text { utilizadas, ou subutilizadas, } \\
\text { inseridas na malha urbana e } \\
\text { dotadas de infraestrutura e } \\
\text { equipamentos; } \\
\text { Utilização prioritária de terrenos } \\
\text { de propriedade do Poder Público; } \\
\text { Prioridade para planos, } \\
\text { programas e projetos } \\
\text { habitacionais articulados no } \\
\text { âmbito federal, estadual e } \\
\text { municipal; } \\
\text { Articulação com as demais } \\
\text { políticas públicas (saneamento, } \\
\text { mobilidade urbana, assistência } \\
\text { social, saúde, educação, etc.); } \\
\text { Promoção da regularização } \\
\text { fundiária; } \\
\text { Incentivo à implementação dos } \\
\text { diversos institutos jurídicos que } \\
\text { regulamentam o acesso à } \\
\text { moradia; } \\
\text { trabalho social } \\
\text { Apoio e incentivo à elaboração } \\
\text { de diretrizes, normas e } \\
\text { procedimentos para a prevenção } \\
\text { e erradicação de riscos; } \\
\text { Mitigação de conflitos fundiários; } \\
\end{array}$ & $\begin{array}{l}\text { Sustentabilidade } \\
\text { econômica, financeira e } \\
\text { social dos programas e } \\
\text { projetos implementados; } \\
\text { Adoção de mecanismos } \\
\text { de acompanhamento e } \\
\text { avaliação de indicadores } \\
\text { de impacto social das } \\
\text { políticas, planos e } \\
\text { programas; } \\
\text { Atendimento às normas } \\
\text { de preservação ambiental, } \\
\text { eliminando ou mitigando } \\
\text { os impactos ambientais } \\
\text { negativos na área objeto } \\
\text { de intervenção e seu } \\
\text { respectivo entorno; } \\
\text { No caso de realocação de } \\
\text { famílias, evitar novas } \\
\text { ocupações na área } \\
\text { anteriormente ocupada, } \\
\text { por meio da execução de } \\
\text { obras de urbanização e } \\
\text { recuperação ambiental; } \\
\text { O reassentamento total de } \\
\text { famílias deverá ocorrer } \\
\text { somente nos casos em } \\
\text { que o assentamento } \\
\text { precário esteja em área } \\
\text { imprópria para o uso } \\
\text { habitacional; } \\
\text { O reassentamento das } \\
\text { famílias deverá ocorrer } \\
\text { para o local mais próximo } \\
\text { possível da antiga área } \\
\text { ocupada; } \\
\text { aovimentação alternativa } \\
\text { ao uso do asfalto }\end{array}$ & $\begin{array}{l}\text { Incentivo à pesquisa, } \\
\text { incorporação de } \\
\text { desenvolvimento } \\
\text { tecnológico e de } \\
\text { formas alternativas de } \\
\text { produção habitacional; } \\
\text { Segurança, } \\
\text { salubridade e } \\
\text { qualidade da } \\
\text { edificação; } \\
\text { Possibilidade de } \\
\text { ampliação das } \\
\text { unidades } \\
\text { habitacionais; } \\
\text { Compatibilidade do } \\
\text { projeto com } \\
\text { características } \\
\text { regionais, locais, } \\
\text { climáticas e culturais; } \\
\text { Acessibilidade }\end{array}$ & $\begin{array}{l}\text { Atendimento prioritário } \\
\text { à população de menor } \\
\text { renda (até } 3 \text { salários } \\
\text { mínimos); } \\
\text { População residente } \\
\text { em áreas sujeitas a } \\
\text { fatores de risco; } \\
\text { Estabelecimento de } \\
\text { quotas para } \\
\text { atendimento a idosos } \\
\text { (3\%), deficientes (3\%) } \\
\text { e famílias chefiadas } \\
\text { por mulheres; } \\
\text { Atendimento à } \\
\text { população com } \\
\text { problemas de } \\
\text { coabitação familiar ou } \\
\text { ônus excessivo com } \\
\text { aluguel (Fundação } \\
\text { João Pinheiro); } \\
\text { Contribuição das } \\
\text { famílias beneficiadas, } \\
\text { sempre que possível }\end{array}$ \\
\hline
\end{tabular}

\subsubsection{Diretrizes relacionadas à Política Urbana}

A relação intrínseca entre terra, mais especificamente terra urbanizada, aquela dotada de infraestrutura e serviços, e a produção do espaço construído (JARAMILLO, 1982), em especial para a produção de moradia, aponta para a importância da integração 
entre as políticas urbana e habitacional. Para Bonduki (2009), a política urbana, deveria atuar, junto com o desenvolvimento da tecnologia, na redução do custo de produção das unidades habitacionais.

Não foi à toa que o Projeto Moradia, ao estabelecer as bases para a estruturação do MCidades, definiu a articulação entre política urbana e política habitacional como uma premissa. Buscou-se incorporá-la tanto às diretrizes do SNHIS, quanto às dos programas habitacionais implementados a partir de 2003, como forma de tentar reverter o quadro histórico, no qual a atuação do Estado brasileiro no setor habitacional acabou fomentando a segregação socioespacial e a "espoliação urbana", caracterizada por Kowarick (2000).

As diretrizes relacionadas à Política Urbana buscam efetivar o direito à cidade e à moradia digna para os moradores de assentamentos precários. A "Promoção do ordenamento territorial das cidades" deveria se realizar por meio da regular ocupação e uso do solo urbano, permitindo à implantação de habitação de interesse social em áreas dotadas de infraestrutura e serviços, próximas dos locais de trabalho. Em harmonia com esta diretriz, foi definida também a "Compatibilização com o Plano Diretor e outros planos setoriais", como os planos de habitação, de saneamento, de mobilidade urbana, de saúde, de educação, entre outros, ou seja, por meio da "Articulação com as demais políticas públicas" (BRASIL, 2005; CGFNHIS, 2006 e 2007).

Como vimos no capítulo anterior, os projetos implementados pela HABITAFOR entre 2005 e 2012 foram concebidos em sua maioria sob a gestão de Olinda Marques no órgão, que durou até meados de 2009. Apesar dos avançados instrumentos jurídicos e urbanísticos trazidos pelo Estatuto da Cidade, os projetos da HABITAFOR foram concebidos à luz de uma legislação defasada. $O$ plano diretor ${ }^{61}$ então vigente era de

\footnotetext{
61 Havia um processo de atualização do plano diretor, iniciado em 2002, para adequá-lo às premissas do estatuto da Cidade. O chamado LEGFOR foi barrado em 2004 por uma Ação Civil Pública (no 99/2004), ajuizada pelo Ministério Público Federal, que questionava a ausência de participação popular na revisão do plano. Na primeira gestão de Luizianne Lins (2005-2008), a minuta do LEGFOR foi retirada da Câmara dos Vereadores e foi reiniciado o processo de revisão do plano, resultando no Plano Diretor Participativo (PDP) de Fortaleza, de 02 de fevereiro de 2009. Sobre o processo de elaboração e aprovação do PDP, ver Machado (2011).
} 
1992 e a Lei de Uso e Ocupação do Solo (LUOS), de 1996. Além disso, o Código de Obras e Posturas de Fortaleza era de $1981^{62}$.

Quando cruzamos a localização das intervenções realizadas com o zoneamento estabelecido pelo Plano Diretor de Desenvolvimento Urbano (PDDU) de 1992 (Mapa 17), observamos a implantação de conjuntos habitacionais em Zona de Transição $(\mathrm{ZT})$, definidas pelo PDDU como "área não adensada, sem infraestrutura de água e esgoto [...] com características urbanas e agrárias” (FORTALEZA, 1992). Ou seja, uma zona onde não se deveria estimular a ocupação antes de outras áreas da cidade, já dotadas de infraestrutura e serviços.

Mapa 17 - Intervenções realizadas pela HABITAFOR X PDDU-199263

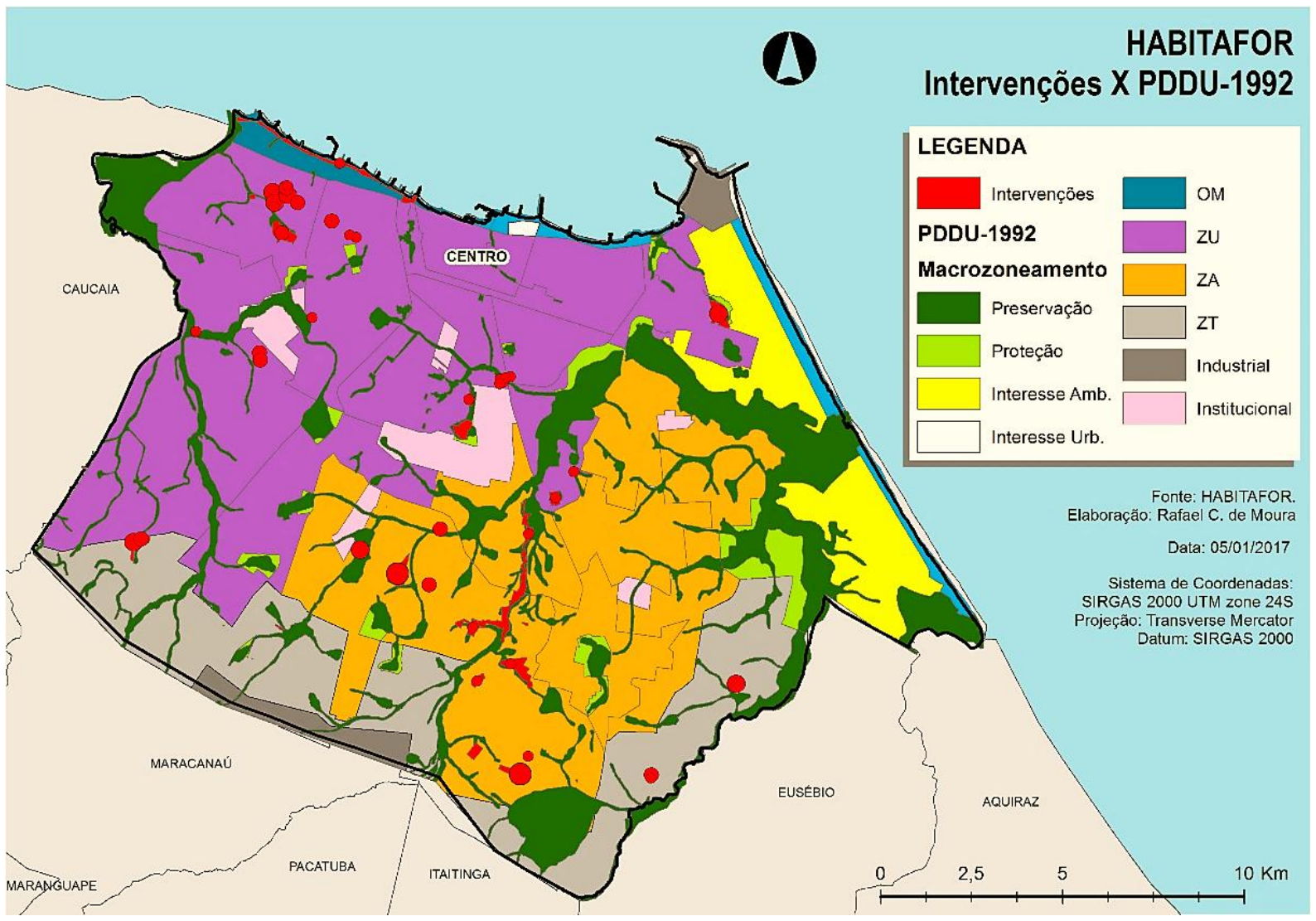

Fonte: HABITAFOR e PDDU-1992, elaboração do autor

62 A Lei de Uso e Ocupação do Solo e o Código de Obras e Posturas estão vigentes ainda hoje, início do ano de 2017. Contudo, ambas as legislações têm passado por um processo de revisão, no qual a participação da sociedade foi mínima, para não dizer inexistente. As minutas para a nova legislação (Projetos de Lei Complementar no 01/2016 e 24/2016, respectivamente) já se encontram na Câmara dos Vereadores para análise e aprovação, mesmo com inúmeras críticas (O POVO, 2016a).

63 OM - Orla Marítima; ZU - Zona Urbanizada; ZA - Zona Adensável; ZT - Zona de Transição (FORTALEZA, 1992). 
Também é possível observar uma grande quantidade de intervenções na Zona Adensável (ZA), considerada pelo PDDU como parcialmente atendida pelas infraestruturas de água e esgoto (Mapa 17). Este fato pode ser explicado por se tratar da área onde se encontram os próprios assentamentos precários que originaram estas intervenções.

Ao confrontarmos a localização das intervenções com o zoneamento posteriormente definido no Plano Diretor Participativo (PDP) de 2009 (Erro! Fonte de referência não encontrada.), observamos alguns conjuntos localizados em Zona de Ocupação Restrita (ZOR), ou próximas de seus limites. Esta zona, que se caracteriza pela "ocupação esparsa, carência ou inexistência de infraestrutura e equipamentos públicos e incidência de glebas e terrenos não utilizados” (FORTALEZA, 2009), tem como objetivos inibir e conter a expansão urbana, bem como dotar de infraestrutura as áreas já ocupadas.

Por outro lado, as intervenções que se encontram em Zona de Requalificação Urbana (ZRU-1 e ZRU-2) (Erro! Fonte de referência não encontrada.), atendem aos objetivos do PDP para estas zonas, nas quais se deve promover a requalificação urbanística e ambiental, buscando a integração dos assentamentos precários existentes (FORTALEZA, 2009). Também é possível observar algumas poucas intervenções localizadas em Zona de Ocupação Preferencial (ZOP-1), considerada a melhor localização pela disponibilidade de infraestrutura e serviços, bem como pela presença de imóveis não utilizados e subutilizados, destinando-se à dinamização e intensificação do uso e ocupação do solo (CARNEIRO, 2013).

Com relação à LUOS, seu Capítulo V, que trata da "Instituição de Áreas para Aglomerados Populares", foi fundamental na definição dos projetos elaborados pela HABITAFOR. O instrumento "Zona Residencial Especial" (ZRE), art. 206, definia algumas características gerais para a concepção de projetos de intervenção em "Assentamentos Espontâneos", reconhecidas pelo PDDU-1992, mas que não foram delimitadas, como as Zonas Especiais de Interesse Social (ZEIS) do PDP-2009.

Ainda segundo a LUOS, os parâmetros urbanísticos deveriam observar: um Índice de Aproveitamento igual a 1,8; uma Taxa de Ocupação máxima de 80\%, para qualquer tipo de uso; um recuo de fundo obrigatório mínimo de dois metros, com os recuos de 
frente e lateral opcionais; e edificações com até dois pavimentos. Os projetos implementados pela HABITAFOR entre 2005 e 2012 procuraram seguir os parâmetros aqui mencionados, com algumas exceções, como Rosalina, PREURBIS - Cocó e Vila do Mar, por terem sido concebidos fora da HABITAFOR, pela Coordenadoria de Habitação da SEINF, e Maravilha, cujo partido arquitetônico e urbanístico tem origem ainda na gestão Juraci Magalhães, apesar de ter passado por alterações posteriormente.

Mapa 18 - Intervenções realizadas pela HABITAFOR X PDP-200964

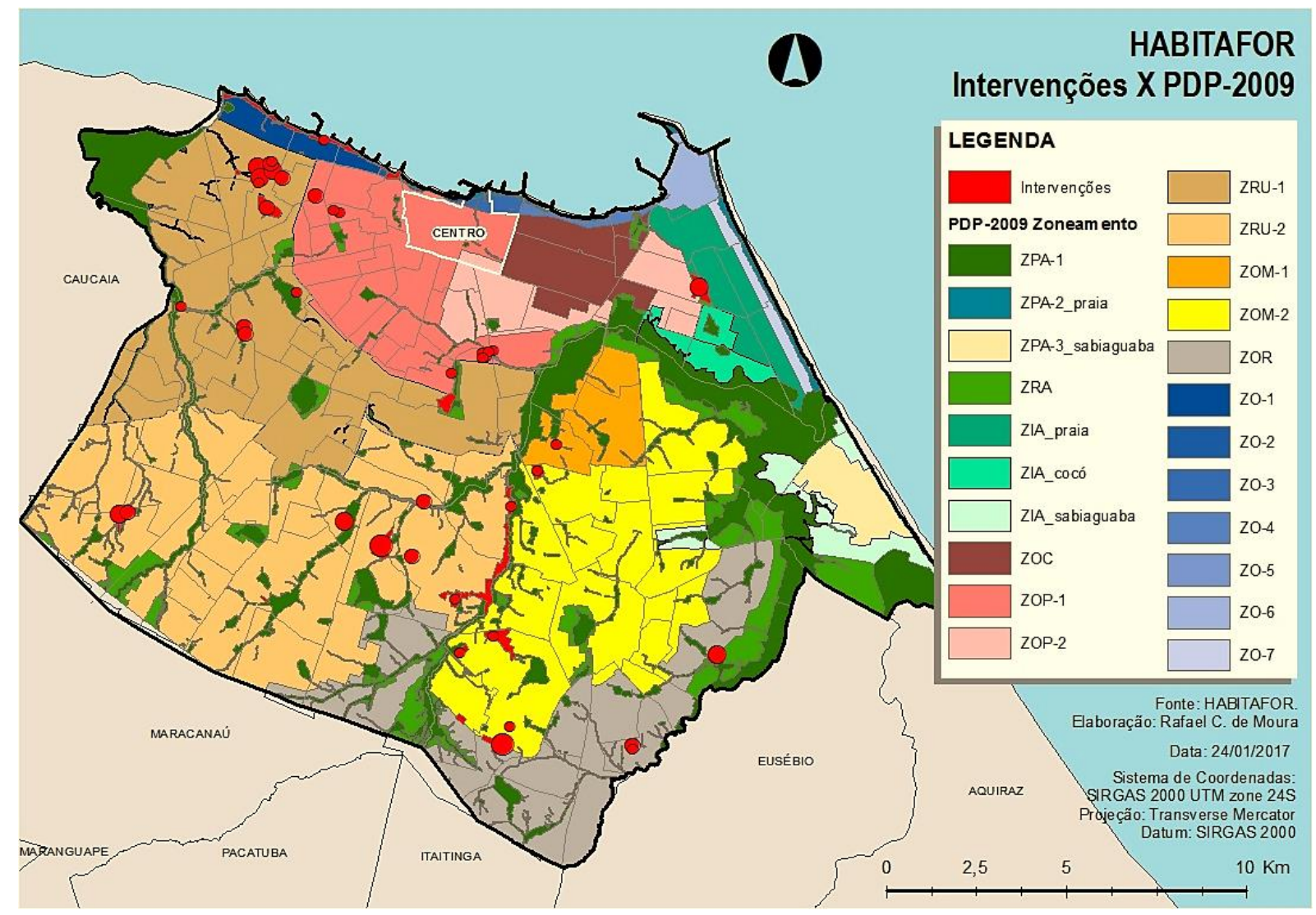

Fonte: HABITAFOR e PDP-2009, elaboração do autor

Duas diretrizes se referem mais diretamente à questão do acesso à terra urbanizada: a "Utilização prioritária de áreas não utilizadas, ou subutilizadas" e a "Utilização

64 ZPA-1 - Zona de Preservação Ambiental; ZPA-2 - Zona de Preservação Ambiental da Faixa de Praia; ZPA-3 - Zona de Preservação Ambiental do Parque Natural Municipal das Dunas de Sabiaguaba; ZRA - Zona de Recuperação Ambiental; ZIA Praia - Zona de Interesse Ambiental da Praia do Futuro; ZIA Sabiaguaba - Zona de Interesse Ambiental da Sabiaguaba; ZIA Cocó - Zona de Interesse Ambiental do Cocó; ZOC - Zona de Ocupação Consolidada; ZOP-1 - Zona de Ocupação Preferencial 1; ZOP-2 - Zona de Ocupação Preferencial 2; ZRU-1 - Zona de Requalificação Urbana 1; ZRU-2 - Zona de Requalificação Urbana 2; ZOM-1 - Zona de Ocupação Moderada 1; ZOM-2 - Zona de Ocupação Moderada 2; ZOR - Zona de Ocupação Restrita; ZO-1 - Zona da Orla Trecho 1; ZO-2 Zona da Orla Trecho 2; ZO-3 - Zona da Orla Trecho 3; ZO-4 - Zona da Orla Trecho 4; ZO-5 - Zona da Orla Trecho 5; ZO-6 - Zona da Orla Trecho 6; ZO-7 - Zona da Orla Trecho 7 (FORTALEZA, 2009). 
prioritária de terrenos de propriedade do Poder Público". Se, por um lado, a HABITAFOR procurou, a partir de 2005, utilizar terrenos públicos, particularmente aqueles do Fundo de Terras, para elaborar suas intervenções, em razão da escassez de verbas para a desapropriação de terrenos pelo município (BISIO, 2016; CARNEIRO, 2016; RODRIGUES, 2016), por outro lado, poucos projetos fizeram uso dos vazios urbanos bem localizados.

Podemos citar como exemplo do emprego de terrenos vazios ou subutilizados, as áreas de reassentamento do projeto Vila do Mar, que utilizaram terrenos de fábricas desativadas na região oeste de Fortaleza, ou os projetos Maravilha, Lagoa do Papicu e Açude João Lopes, que usaram terrenos vazios próximos às áreas de origem dos assentamentos. Contudo, nenhuma destas intervenções fez uso dos instrumentos incluídos no Estatuto da Cidade, de modo a facilitar o acesso à terra urbanizada.

Com relação à "Prioridade para planos, programas e projetos habitacionais articulados no âmbito federal, estadual e municipal", a maioria das intervenções da HABITAFOR se realizaram em parceria com o governo federal (Quadro 7), o que demonstra uma dependência do município de recursos externos para conduzir sua política habitacional, seja por incapacidade financeira, seja por desinteresse político.

Por sua vez, a articulação com o governo estadual foi praticamente inexistente, até mesmo por uma visão do governo de que a prefeitura se apresentava mais como um empecilho à realização de suas ações do que como parceira (RODRIGUES, 2016). Segundo Marques (2016), mais recentemente, município e estado têm firmado mais parcerias no setor habitacional, com transferência de recursos financeiros e técnicos entre ambos. Além disso, a prefeitura tem procurado captar recursos para habitação por meio de empréstimos de longo prazo (MARQUES, 2016).

A "Articulação das intervenções com as demais políticas públicas", por meio da compatibilização com seus planos específicos, deixou muito a desejar. Primeiramente, não havia PLHIS, nem plano municipal de saneamento, nem plano municipal de mobilidade. O que existia eram apenas projetos sem plano. O PLHIS, que deveria orientar a atuação do órgão, foi concluído apenas ao final de 2012 e, com as mudanças de gestão ocorridas em 2013, o plano foi deixado de lado, apesar de ter passado por uma atualização superficial em 2016, no âmbito do Fortaleza 2040, um 
processo de planejamento de longo prazo para a cidade, iniciado em 2013 e concluído em 2016. Inclusive, a HABITAFOR, após a transformação em secretaria, voltou a ser um órgão mais executivo das ações habitacionais. A função de planejamento da habitação foi transferida para o IPLANFOR, inclusive a de regulamentação das ZEIS.

Em segundo lugar, o foco atribuído pelo governo federal ao PMCMV, a partir de 2009, enfraqueceu a estrutura "CPF" concebida inicialmente pelo Ministério das Cidades, já que a definição das intervenções no PMCMV passou se dar entre construtoras e CAIXA. Portanto, da forma como foi proposto, o programa não requer dos municípios uma capacidade institucional como condição para que se realizem os investimentos, permitindo que os interesses do mercado imobiliário prevaleçam sobre o interesse coletivo (FREITAS e PEQUENO, 2011). Assim, as administrações locais passaram a se concentrar nas ações de provisão habitacional e praticamente abandonaram as outras linhas de ação, como aquelas voltadas para a urbanização de assentamentos precários, para as melhorias habitacionais e para a regularização fundiária.

Em Fortaleza, ao final da gestão Luizianne Lins (2005-2012), grande parte das obras estavam paralisadas, ou ocupadas por movimentos de moradia (Tabela 4). Na gestão Roberto Cláudio (2013-2016), elas acabaram abandonadas, ou readequadas ao PMCMV65. Mesmo as urbanizações de favelas têm sido renegociadas com a CAIXA, no sentido de se reduzirem as metas físicas das obras, a fim de encerrarem os contratos com o governo federal (AQUINO, PAIVA e BRAGA, 2016; MARQUES, 2016).

Tabela 4 - Situação das obras da HABITAFOR iniciadas entre 2005 e 2012, em 31/01/2013

\begin{tabular}{l|l|l}
\hline INTERVENÇÃO / LICITAÇÃO & SITUAÇÃO & $\%$ EXEC. \\
\hline Açude João Lopes & Paralisada & $88,59 \%$ \\
Anita Garibaldi & Concluída & $100,00 \%$ \\
Autran Nunes & Concluída & $100,00 \%$ \\
Bárbara de Alencar I & Entregue & $77,62 \%$ \\
Bárbara de Alencar II & Paralisada & $24,79 \%$ \\
Casa e Renda & Entregue & $90,00 \%$ \\
Itaperussu & Paralisada & $10,00 \%$ \\
Jana Barroso & Paralisada & $95,29 \%$ \\
Lagoa da Zeza / Vila Cazumba / Maria Tomásia (1a. licitação) & Em obras & $97,00 \%$
\end{tabular}

65 Segundo Aquino, Paiva e Braga (2016), a prefeitura realizou uma Chamada Pública para construtoras interessadas em produzir conjuntos habitacionais através do PMCMV, incluindo terrenos de reassentamentos de projetos que estavam paralisados, como Itaperussu, Lagoa do Urubu, Lagoa do Papicu, São Cristóvão / Campo Estrela e Vila do Mar. Contudo, vários terrenos não atraíram o interesse das empreiteiras, permanecendo a necessidade de se concluir as intervenções já iniciadas. 


\begin{tabular}{l|l|l}
\hline INTERVENÇÃO / LICITAÇÃO & SITUAÇÃO & $\%$ EXEC. \\
\hline Lagoa da Zeza / Vila Cazumba / Maria Tomásia (2a. licitação) & Ocupada / Paralisada & $33,73 \%$ \\
Lagoa do Papicu & Ocupada / Paralisada & $59,91 \%$ \\
Lagoa do Urubu & Paralisada & $48,73 \%$ \\
Maravilha (1a. licitação) & Paralisada & $99,90 \%$ \\
Maravilha (2a. licitação) & Paralisada & $74,71 \%$ \\
Marrocos & Paralisada & $41,89 \%$ \\
Planalto Pici I (80 unidades) & Concluída & $100,00 \%$ \\
PREURBIS - Cocó & Ocupada / Paralisada & $65,35 \%$ \\
Rosa Luxemburgo & Concluída & $100,00 \%$ \\
Rosalina (1a. licitação) & Contrato Rescindido & $27,21 \%$ \\
Rosalina (2a. licitação) & Em obras & $4,17 \%$ \\
Sabiá & Paralisada & $88,72 \%$ \\
São Cristóvão (Lotes Remanescentes + Reassentamento) & Ocupada / Paralisada & $13,81 \%$ \\
Campo Estrela & Paralisada & $16,13 \%$ \\
Socorro Abreu & Entregue & $100,00 \%$ \\
Urucutuba & Ocupada / Paralisada & $10,12 \%$ \\
Vila do Mar - terreno 01 & Entregue & $100,00 \%$ \\
Vila do Mar - terreno 02 & Em obras & $70,00 \%$ \\
Vila do Mar - terreno 03 & Em obras & $46,46 \%$ \\
Vila do Mar - terreno 04 & Em obras & $3,60 \%$ \\
Vila do Mar - urbanização & Em obras & $70,46 \%$ \\
\hline
\end{tabular}

Fonte: HABITAFOR

O próprio orçamento do órgão foi sendo reduzido (Tabela 5), pois no PMCMV os contratos se estabelecem entre CAIXA e construtoras. A equipe técnica da HABITAFOR também foi reduzida, já que não havia mais a mesma necessidade de elaboração e acompanhamento de projetos (Tabela 6).

Tabela 5 - Evolução orçamentária da HABITAFOR entre 2012 e 2016

\begin{tabular}{cccc}
\hline EXERCíCIO & DOTAÇÃO FINAL (A) & EXECUTADO (B) & \% EXECUÇÃO (A/B) \\
\hline $\mathbf{2 0 1 2}$ & $\mathrm{R} \$ 117.484 .346$ & $\mathrm{R} \$ 74.813 .525$ & $63,68 \%$ \\
$\mathbf{2 0 1 3}$ & $\mathrm{R} \$ 110.588 .847$ & $\mathrm{R} \$ 29.888 .494$ & $27,03 \%$ \\
$\mathbf{2 0 1 4}$ & $\mathrm{R} \$ 79.551 .668$ & $\mathrm{R} \$ 24.008 .297$ & $30,18 \%$ \\
$\mathbf{2 0 1 5}$ & $\mathrm{R} \$ 17.260 .665$ & $\mathrm{R} \$ 15.386 .061$ & $89,14 \%$ \\
$\mathbf{2 0 1 6}$ & $\mathrm{R} \$ 17.010 .532$ & $\mathrm{R} \$ 2.268 .599$ & $13,34 \%$ \\
\hline
\end{tabular}

Fonte: SEPOG apud Fortaleza 2040 (oficina do PLHIS, 07/05/2016), adaptado pelo autor

Tabela 6 - Evolução do quantitativo de funcionários da HABITAFOR entre 2012 e 2016

\begin{tabular}{lrrrrr}
\hline VíNCULO & $\mathbf{2 0 1 2}$ & $\mathbf{2 0 1 3}$ & $\mathbf{2 0 1 4}$ & $\mathbf{2 0 1 5}$ & $\mathbf{2 0 1 6}$ \\
\hline Servidores à Disposição & 13 & 12 & 14 & 10 & 10 \\
Cargos Comissionados & 33 & 33 & 33 & 35 & 35 \\
Terceirizados (SERVNAC) & 180 & 177 & 125 & 127 & 132 \\
Terceirizados (THOMPSON) & 84 & 92 & 30 & 16 & 17 \\
Servidores Próprios & 0 & 0 & 0 & 0 & 0 \\
\hline TOTAL & $\mathbf{3 1 0}$ & $\mathbf{3 1 4}$ & $\mathbf{2 0 2}$ & $\mathbf{1 8 8}$ & $\mathbf{1 9 4}$ \\
\hline
\end{tabular}

Fonte: HABITAFOR apud Fortaleza 2040 (oficina do PLHIS, 07/05/2016), adaptado pelo autor 
Quanto à "Promoção da regularização fundiária", apesar dos instrumentos do Estatuto da Cidade, até o início da gestão Luizianne Lins, em 2005, não havia em Fortaleza uma política pública municipal de regularização fundiária, haviam apenas iniciativas da sociedade civil (ABREU NETO, 2008).

A partir de 2005, a HABITAFOR passou a realizar três tipos de ação de regularização fundiária: a regularização de antigos conjuntos de mutirão realizados pela COMHAB nos anos 1990; a regularização de áreas de assentamento precário selecionadas por meio do Orçamento Participativo (ABREU NETO, 2008); e a regularização das intervenções promovidas pela própria HABITAFOR. Contudo, nenhuma das 28.917 ações de regularização fundiária em andamento foi concluída até meados de 2011 , o que não surpreende, quando se consideram os obstáculos ao processo (GONDIM, 2013).

Outra diretriz que vai ao encontro da regularização fundiária é o "Incentivo à implementação dos diversos institutos jurídicos que regulamentam o acesso à moradia". Da criação do Estatuto da Cidade, em 2001, até os dias atuais, poucos foram os instrumentos que ampliam o acesso à moradia que foram regulamentados e implementados pela Prefeitura de Fortaleza. Em 29 de outubro de 2007, foi aprovada a lei no 9.294, que regulamentou a utilização da Concessão de Direito Real de Uso (CDRU) de imóveis públicos, construídos ou adquiridos no âmbito da PHIS. Outro instrumento que chegou a ser utilizado nos processos de regularização fundiária foi a Usucapião Urbana, que aplicada nos casos do Marcado Velho, Lagoa do Opaia e Marrocos. Pela demora do sistema judiciário brasileiro, procurava-se evitar essa opção.

O diálogo com as outras secretarias setoriais foi ineficiente. Podemos citar o caso dos equipamentos comunitários construídos pela HABITAFOR para atender ao conjunto Rosa Luxemburgo, como exemplo da falta de planejamento inter-secretarias, que, resultou no abandono e na ocupação das edificações por famílias necessitando de moradia (Figura 2).

No Maria Tomásia, pela dimensão do conjunto (1.126 unidades habitacionais), por sua localização periférica na cidade e por sua grande distância em relação às áreas de origem das famílias, houve uma necessidade de maior articulação entre os órgãos, 
levando à criação do Grupo de Trabalho (GT) Território de Habitabilidade. O GT tinha como objetivo planejar a implementação de políticas públicas paras as famílias que seriam realocadas para o conjunto Maria Tomásia e incluía tanto órgãos municipais, quanto órgãos externos à prefeitura (HABITAFOR, 2009). Um de seus resultados foi a criação de uma linha específica de ônibus para o atendimento dos novos moradores do Maria Tomásia, pois anteriormente a área não era servida por transporte público. Contudo, mesmo com a realização do GT, Dias (2013) apresenta diversas dificuldades pelas quais passam os moradores Maria Tomásia quanto ao acesso a equipamentos e serviços públicos.

Figura 2 - Ocupação dos equipamentos comunitários destinados ao conjunto Rosa Luxemburgo
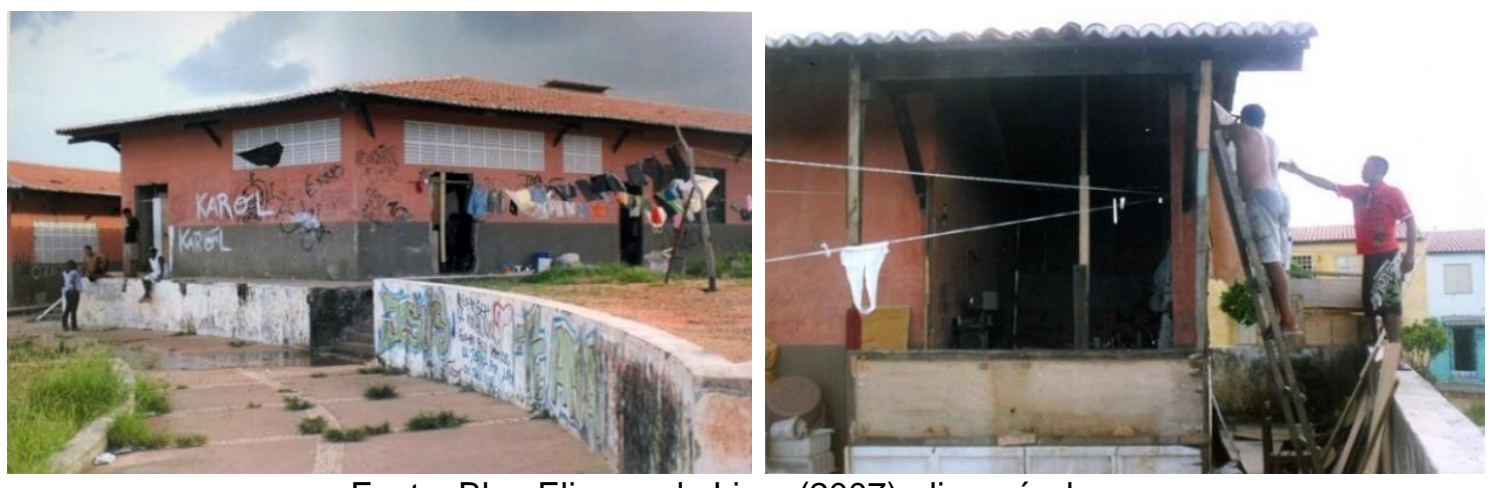

Fonte: Blog Eliomar de Lima (2007), disponível em:

<http://blog.opovo.com.br/blogdoeliomar/semtetosinvademconjuntorosaluxemburgo/>, acesso em: 04/08/2016

No Maria Tomásia, pela dimensão do conjunto (1.126 unidades habitacionais), por sua localização periférica na cidade e por sua grande distância em relação às áreas de origem das famílias, houve uma necessidade de maior articulação entre os órgãos, levando à criação do Grupo de Trabalho (GT) Território de Habitabilidade. O GT tinha como objetivo planejar a implementação de políticas públicas paras as famílias que seriam realocadas para o conjunto Maria Tomásia e incluía tanto órgãos municipais, quanto órgãos externos à prefeitura (HABITAFOR, 2009). Um de seus resultados foi a criação de uma linha específica de ônibus para o atendimento dos novos moradores do Maria Tomásia, pois anteriormente a área não era servida por transporte público. Contudo, mesmo com a realização do GT, Dias (2013) apresenta diversas dificuldades pelas quais passam os moradores Maria Tomásia quanto ao acesso a equipamentos e serviços públicos.

Além da desarticulação entre os órgãos da própria prefeitura, havia o mesmo problema com órgãos externos, como as concessionárias de serviços públicos, 
$\operatorname{COELCE}^{66}$ (energia elétrica) e CAGECE (água e esgoto). Em relação à COELCE, costumava haver problemas com as solicitações de ligação das unidades habitacionais dos conjuntos produzidos. Por sua vez, Bisio (2016) aponta como dificuldade no relacionamento com a CAGECE as frequentes alterações nas normativas do órgão dificultavam a aprovação dos projetos da HABITAFOR.

A CAGECE também costumava se eximir do acompanhamento da execução das obras das estações de tratamento de esgoto, ou elevatórias, dos conjuntos habitacionais, mesmo com a existência de convênios firmados entre o órgão e a HABITAFOR, que eram uma exigência do MCidades. Desta forma, os equipamentos não foram recebidos, nem operacionalizados pela CAGECE, resultando em problemas pela falta de manutenção (AQUINO, PAIVA e BRAGA, 2016).

Outro órgão com o qual havia uma dificuldade de relação era o Corpo de Bombeiros. As exigências das normas de segurança acabaram se tornando uma limitação para uma maior verticalização da tipologia habitacional utilizada pela HABITAFOR.

A fim evitar a instalação de um reservatório de água específico para combate a incêndio, e outros equipamentos, bem como poupar os moradores de custos condominiais resultantes da manutenção destes equipamentos, a HABITAFOR recorreu à definição de uma tipologia habitacional padrão, utilizada na maioria de seus projetos, que reduzisse a necessidade desses equipamentos (BISIO, 2016; CARNEIRO, 2016; HATSUE, 2016; RODRIGUES, 2016). Estes se restringiram à instalação de casa de gás externa à edificação, que não costumava ser utilizada pelos moradores devido aos constantes furtos de botijões, e de um extintor de incêndio interno ao bloco, no hall da escada.

O "Apoio e incentivo à elaboração de diretrizes, normas e procedimentos para a prevenção e erradicação de riscos" é uma regra cuja que ultrapassa a competência do órgão de habitação. Entre 2005 e 2012, apesar da atuação da HABITAFOR ter tido um foco nas áreas de risco de Fortaleza, do processo de estruturação pelo qual passou a Defesa Civil (MARQUES, 2016) e da realização de ações como a limpeza

\footnotetext{
${ }^{66}$ Em 08 de novembro de 2016, a COELCE - Companhia Energética do Ceará - passou a se chamar Enel Distribuição Ceará, carregando o nome de sua controladora italiana (Enel) (O POVO, 2016b)
} 
de canais para reduzir os alagamentos e inundações, não houve a elaboração e implementação de um plano municipal de prevenção e erradicação de riscos, que consolidasse uma política pública. Para piorar, o PMCMV, com sua seleção de demandas por meio de sorteio, contribuiu para que as áreas de riscos não fossem mais contempladas na sua totalidade pelas ações de provisão habitacional.

Quanto à "Mitigação de conflitos fundiários", nenhuma das intervenções trabalhadas pela HABITAFOR atuou diretamente em áreas onde os moradores estivessem ameaçados de despejo. Contudo algumas ações foram realizadas em áreas de interesse para o mercado imobiliário, exercendo pressão sobre os assentamentos. Nesta situação se encontravam os projetos Lagoa do Papicu, Lagoa do Opaia/Planalto Universo, Maravilha e Vila do Mar.

Borges verifica uma ampliação no mercado imobiliário interno aos próprios assentamentos, que "A partir do momento em que a Prefeitura atua em determinado local e que os moradores reconhecem a possibilidade de urbanização da área, 0 imóvel ali localizado passa a adquirir um valor de troca superior ao valor de uso" (BORGES, 2012, p. 100). Assim, emerge uma nova possibilidade de conflitos, que a HABITAFOR procurou debelar através da proibição da venda ou aluguel dos imóveis doados por meio dos programas habitacionais do município.

A última diretriz do MCidades que relacionamos à integração entre Política Urbana e Política Habitacional diz respeito à "Obrigatoriedade de execução do trabalho social" nas intervenções implementadas por meio dos programas do governo federal. Estes previam um acompanhamento social anterior à intervenção, durante as obras e por pelo menos mais seis meses após a conclusão das obras. Conforme diretrizes da CAIXA e do MCidades, o trabalho social deveria incluir atividades nos eixos de mobilização e organização comunitária, educação ambiental e geração de trabalho e renda (GONDIM, 2013). Sobre o trabalho social nas intervenções da HABITAFOR, escreveu Gondim:

Limitações de ordem técnica e financeira, porém, praticamente inviabilizaram a realização de tal trabalho, que passou a ser mais a exceção do que a regra nos projetos habitacionais de responsabilidade da Habitafor. Um dos entraves era a lentidão dos procedimentos burocráticos para licitar, contratar e pagar as empresas. [...]. Outro fator que comprometeu o acompanhamento pós- 
ocupação foi a escassez de empresas com experiência nesse tipo de trabalho [...] (GONDIM, 2013, p. 158).

De modo geral, as etapas de contato inicial, cadastramento, elaboração de diagnóstico social e concepção do Plano de Trabalho Técnico Social (PTTS), a ser executado pela empresa a ser contratada, eram realizados por técnicos da HABITAFOR. Em que pese a não realização do trabalho social em si, considerando os eixos previamente citados, havia um contato frequente entre a equipe social com os moradores das áreas de intervenção. Diferentemente, com o PMCMV foi constatado que esse contato entre técnicos do trabalho social e moradores tornou-se bastante reduzido e descontínuo (PEQUENO e ROSA, 2016).

\subsection{Diretrizes relacionadas à Intervenção e seu Entorno}

O descompasso entre a realização do trabalho social, ou mesmo sua não execução dificultaram a efetivação da diretriz de "Sustentabilidade econômica, financeira e social dos programas implementados", nas intervenções da HABITAFOR realizadas entre 2005 e 2012.

Do ponto de vista econômico, a formalização da situação de moradia, através dos conjuntos habitacionais, apresentou alguns ônus para os moradores, como os custos referentes a água, esgoto e energia elétrica, que anteriormente poderiam ser acessados por meio de ligações clandestinas ${ }^{67}$. Sem contar os custos com transporte para aquelas famílias que foram deslocadas para áreas mais distantes. A realização do trabalho social, especialmente no que se refere ao eixo voltado para a geração de trabalho e renda, previsto no PTTS, poderia ter contribuído para a redução do impacto desses novos custos na vida das famílias removidas, seja através da criação de oportunidades de emprego, ou de inclusão em programas sociais.

Apesar de trabalhar basicamente com demandas fechadas, o que permitiria a concepção de um projeto customizado para cada comunidade atendida, o descompasso, a desarticulação entre as atividades das equipes de trabalho social e

\footnotetext{
${ }^{67}$ Em matéria do jornal Diário do Nordeste, famílias do conjunto Rosa Luxemburgo questionavam os valores das contas de água e luz. "A casa é ótima, mas não temos como pagar contas tão caras", dizia uma das moradores (DIÁRIO DO NORDESTE, 2007).
} 
de arquitetura e engenharia resultou em intervenções que não conseguiam atender por completo às necessidades das famílias. Por exemplo, na mudança para os conjuntos da HABITAFOR, nem sempre havia pontos comerciais previstos, ou mesmo em número suficiente, ou em dimensões adequadas. O mesmo valia para a definição de equipamentos sociais, como creches, centros comunitários, entre outros, que, quando existiam, nem sempre davam conta da demanda.

Também houve casos, em que demandas identificadas posteriormente produziram adequações nos projetos, como a implantação de galpões para catadores de lixo no conjunto Planalto Universo (na intervenção da Lagoa do Opaia) e na Lagoa do Papicu. Nesta última, a solicitação partiu da equipe social da CAIXA (RODRIGUES, 2016).

Diversos fatores dificultaram a efetivação da sustentabilidade sob o prisma social. Durante a execução das obras, o crescimento das famílias gerava a necessidade de inclusão de mais unidades habitacionais nos projetos, ou a previsão de ampliação dos imóveis, opção que não foi trabalhada pelo órgão, especialmente quando detectado após o cadastramento. A chegada de novos moradores por conta das expectativas que a intervenção pública gerava, de uma possibilidade de inclusão no programa, gerava uma pressão pelo aumento da oferta de moradias nas intervenções.

Além disso, um acompanhamento pós-obra ineficiente e a inexistência de um efetivo controle urbano, possibilitaram a ocorrência de novas ocupações (Mapa 19) em áreas vizinhas às das intervenções, como no conjunto Jana Barroso e Bárbara de Alencar II, ou dentro dos limites do próprio conjunto, como no Socorro Abreu e Maria Tomásia, neste último foi ocupada uma área destinada a construção de uma praça. Houve também casos de ocupações das próprias obras antes de sua conclusão, gerando novos assentamentos precários, como no Urucutuba e no PREURBIS Cocó.

Borges (2012) também identificou a saída de moradores pela venda ou troca do imóvel, em razão de brigas com vizinhos ou ameaças do tráfico de drogas, ou devido à valorização da casa após a intervenção da Prefeitura. Em outubro de 2009, foi lançada a campanha "Não troco minha casa por nada", que objetivava conscientizar os beneficiários dos conjuntos habitacionais da proibição da venda. Com a campanha, aumentou o número de denúncias contra pessoas que negociavam os imóveis cedidos pela Prefeitura (BORGES, 2012), que passou a realizar procedimentos 
administrativos e judiciais para a retomada dos imóveis, bem como sua transferência para outras famílias na lista do cadastro de demandas da HABITAFOR. Essas diversas situações precisavam ser enfrentadas para que de fato fosse atendida a diretriz de sustentabilidade do MCidades.

Mapa 19 - Novas ocupações associadas às intervenções da HABITAFOR

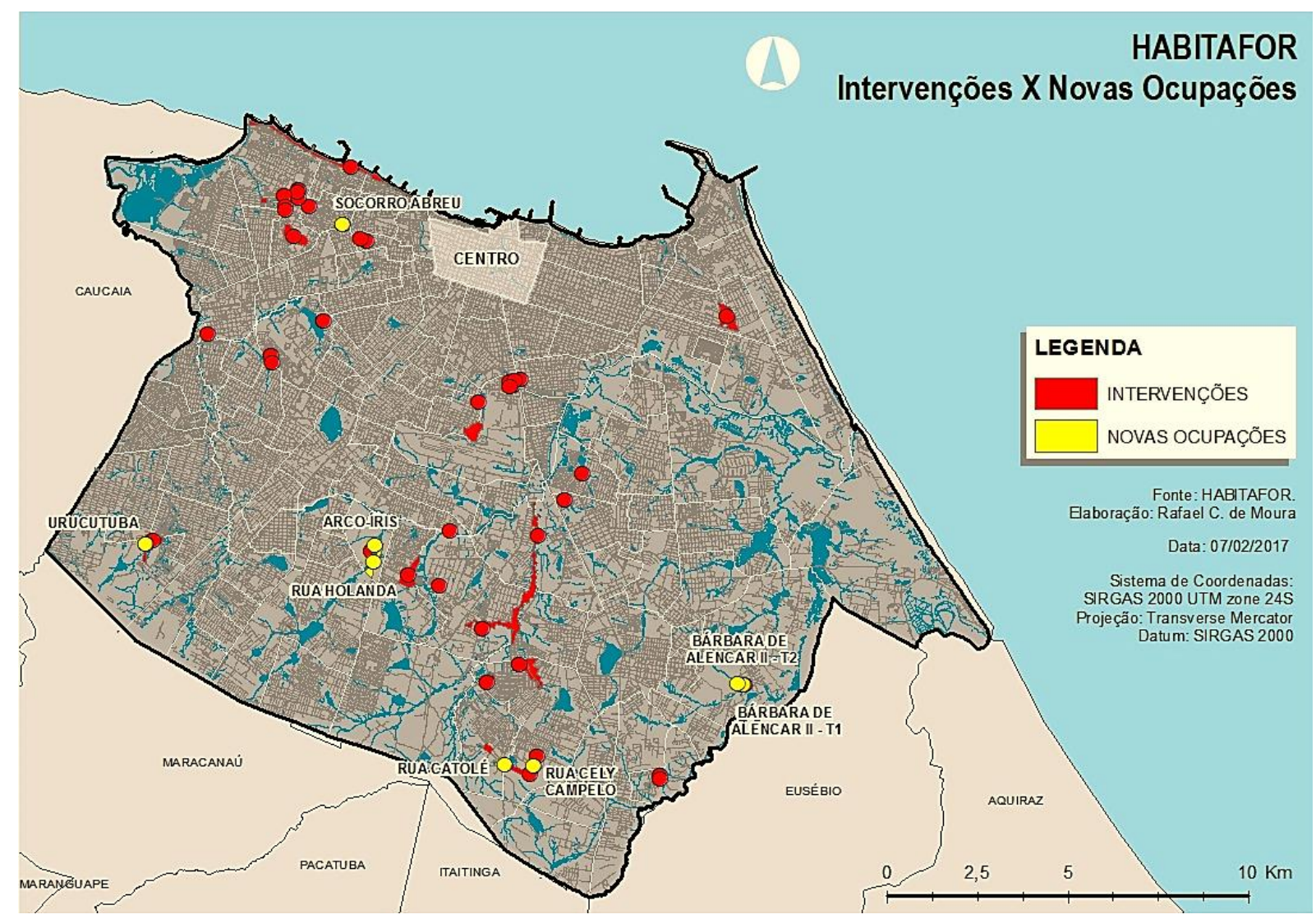

Fonte: HABITAFOR e Google Earth, elaboração pelo autor

Em relação a "Adoção de mecanismos de acompanhamento e avaliação de indicadores de impacto social das políticas, planos e programas", o único instrumento implementado pela Habitafor era a Avaliação Pós-Ocupação (APO), obrigatória pelas normativas do MCidades. As APO eram conduzidas pela equipe do trabalho social, após a entrega das obras, contudo este trabalho foi poucas vezes realizado, em razão das dificuldades de execução do trabalho social já mencionadas e pelo fato de muitas das obras não terem sido plenamente concluídas (Tabela 4).

As áreas de risco em Fortaleza estão historicamente relacionadas às margens dos recursos hídricos e à faixa litorânea, áreas ambientalmente frágeis. Como as intervenções da HABITAFOR focavam nas áreas de risco, até mesmo por ser uma diretriz do MCidades (Quadro 8), era comum que fosse preciso remover famílias para 
conjuntos habitacionais a fim de permitir a recuperação ambiental, especialmente nas Áreas de Preservação Permanente (APP). Com relação às APP's estabelecidas no Código Florestal, lei ㄲo 12.651/2012, Carneiro (2013), em sua pesquisa sobre 14 conjuntos da HABITAFOR, indicou que cinco deles não obedeciam à legislação. Nas intervenções Maravilha, Marrocos, Planalto universo, PREURBIS Cocó e Lagoa do Urubu, existia a APP, mas sua delimitação não seguia o determinado pela lei68.

Em geral, os projetos previam obras de urbanização para as áreas de onde as famílias seriam removidas. Contudo, na prática, muitas dessas obras não foram concluídas, como vemos nos casos da Lagoa da Zeza, Vila Cazumba, Lagoa do Urubu, Lagoa do Papicu, PREURBIS Cocó, entre outros (Tabela 4). Assim, não podemos afirmar, que as diretrizes do MCidades de "Atendimento às normas de preservação ambiental, eliminando ou mitigando os impactos ambientais negativos na área objeto de intervenção e seu respectivo entorno" e "No caso de realocação de famílias, evitar novas ocupações na área anteriormente ocupada, por meio da execução de obras de urbanização e recuperação ambiental" foram completamente efetivadas por meio das intervenções da HABITAFOR.

Duas diretrizes do MCidades se referem mais especificamente à localização das áreas de reassentamento: "O reassentamento total de famílias deverá ocorrer somente nos casos em que o assentamento precário esteja em área imprópria para o uso habitacional" e "O reassentamento das famílias deverá ocorrer para o local mais próximo possível da antiga área ocupada"69. A própria Lei Orgânica do Município de Fortaleza estabelecia em seu artigo 149 que, nos casos em que a remoção de famílias se faz necessária, como em situações de risco, a Prefeitura tem a obrigação de "assentar a respectiva população no próprio bairro ou nas adjacências, em condições de moradia digna, sem ônus para os removidos e com prazos acordados entre a população e a administração municipal (FORTALEZA, 2006).

\footnotetext{
68 Convém lembrar que a Resolução no 369, de 28 de março de 2006, do Conselho Nacional do Meio Ambiente (CONAMA), abriu a possibilidade de supressão de vegetação em APP para alguns casos excepcionais, como para regularização fundiária sustentável de área urbana, para situações em que a remoção completa do assentamento poderia inviabilizar economicamente a intervenção.

69 Não encontramos dentre as diretrizes do Ministério das Cidades, nenhum indicativo para uma distância máxima entre as áreas de origem das famílias e os terrenos de reassentamento.
} 
Nas intervenções da HABITAFOR havia uma busca tanto pela redução do número de remoções, até mesmo como forma de reduzir os custos das obras (MARQUES, 2016), quanto pela aproximação entre as áreas de origem das famílias e as áreas de reassentamentos (RODRIGUES, 2016). Contudo, nem todas obedeceram a essas diretrizes, como podemos observar no Mapa 2070. Os conjuntos Maria Tomásia e Rosa Luxemburgo foram os reassentamentos localizados mais distantes em relação às áreas de origem das famílias.

Mapa 20 - Localização das áreas de Origem e de Reassentamento de intervenções da HABITAFOR

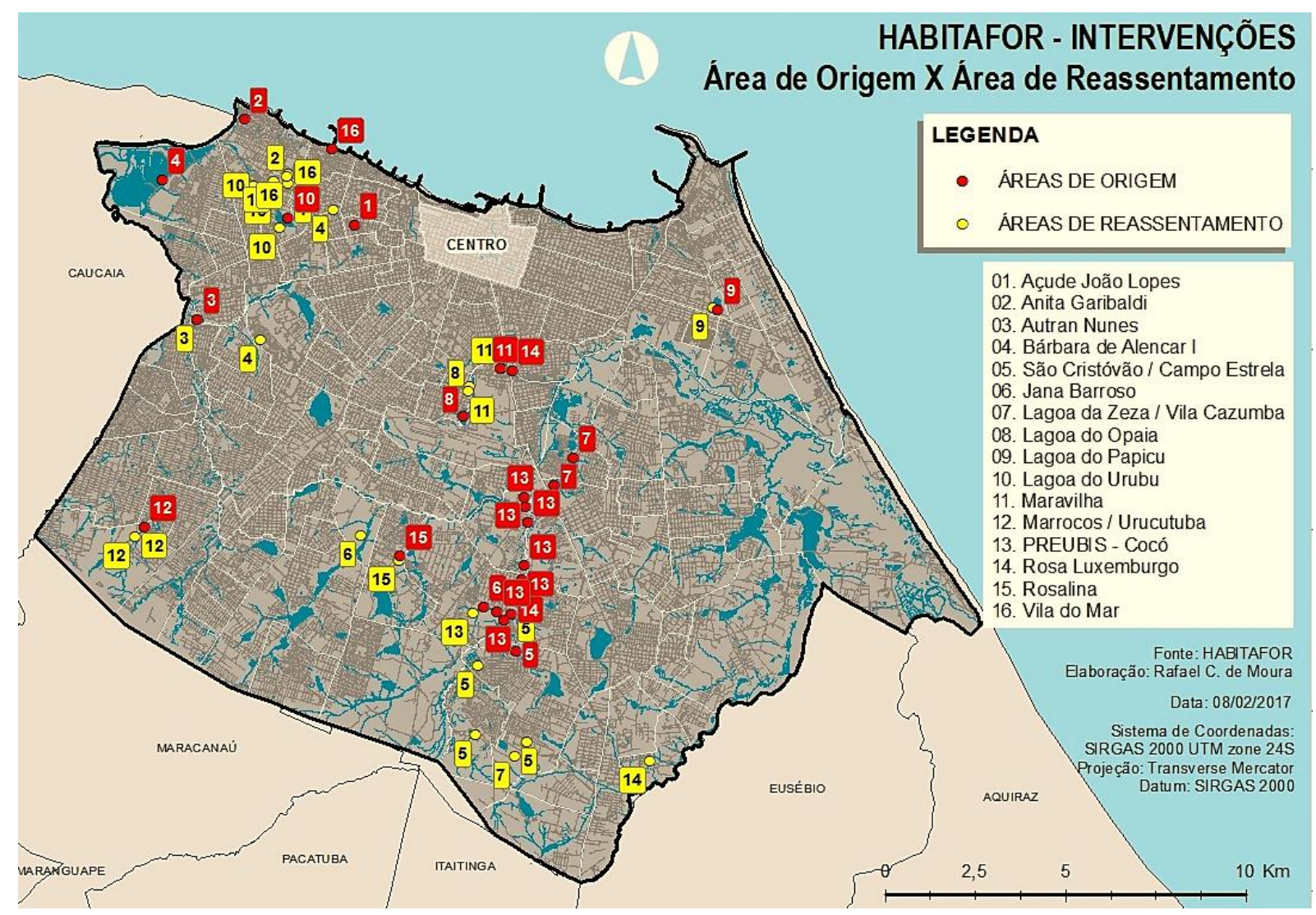

Fonte: HABITAFOR, elaboração do autor

Marques (2016) credita essa impossibilidade de sempre ter os reassentamentos próximos das áreas de origem das famílias à escassez de terras. Por sua vez, Gondim (2013) relaciona à ausência de conhecimentos e experiências locais de intervenções de urbanização de assentamentos precários, bem como ao alto custo dos terrenos em Fortaleza.

70 Não foram consideradas intervenções do tipo Provisão Habitacional, nas quais as famílias têm origens variadas. 
A utilização de "Pavimentação alternativa ao uso do asfalto", tais como pisos intertravados, pré-moldados ou pedras naturais, foi provavelmente a diretriz mais seguida nos projetos da HABITAFOR. Houve um predomínio no uso da pedra tosca como pavimentação do sistema viário, em especial nas vias internas aos conjuntos habitacionais, principalmente em razão do menor custo. Em menor escala, também foi utilizado o paralelepípedo, como na Lagoa do Urubu.

Já os passeios costumavam receber piso cimentado rústico, mas também houve projetos em que se utilizou piso intertravado de concreto, como no Açude João Lopes e no Campo Estrela. O Açude João Lopes foi uma das poucas intervenções nas quais o projeto foi alterado, durante a execução, passando a receber o piso tátil previsto pela NBR9050, visando facilitar a mobilidade de pessoas com deficiência visual (Figura 3).

Figura 3 - Piso intertravado e piso tátil utilizados na intervenção Açude João Lopes

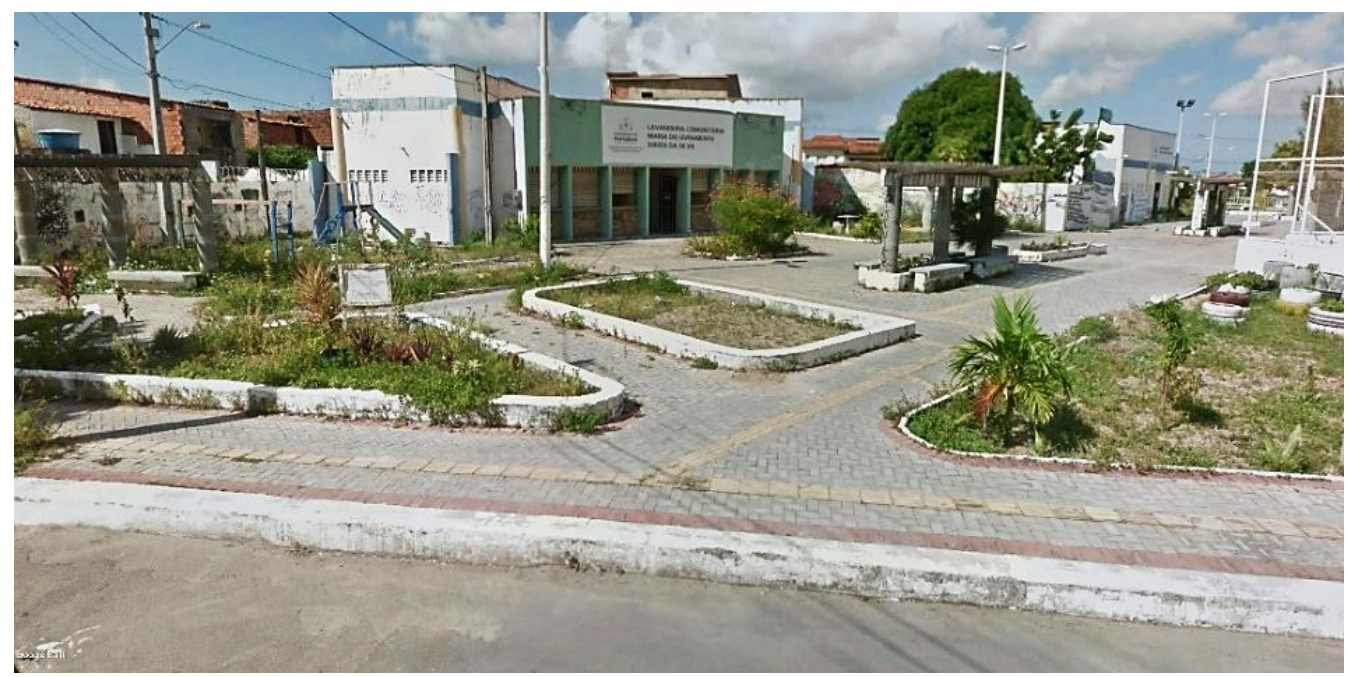

Fonte: Google Earth (2016)

\subsection{Diretrizes relacionadas às Unidades Habitacionais}

Entre 2005 e 2012, muito pouco foi feito pela HABITAFOR relacionado ao "Incentivo à pesquisa, incorporação de desenvolvimento tecnológico e de formas alternativas de produção habitacional". Na grande maioria dos conjuntos, foi utilizada a alvenaria autoportante, com bloco cerâmico, como método construtivo que, aliado ao partido arquitetônico com apenas dois pavimentos (térreo e primeiro piso), resultava em uma obra simples e de menor custo (CARNEIRO, 2016). 
A opção pelo radier protendido como solução para a maioria das fundações das edificações talvez tenha sido a maior incorporação tecnológica nas obras da HABITAFOR nesse período. A dificuldade em se obter informações sobre os solos das áreas de intervenção, através de procedimentos de sondagem, levou à adoção do radier protendido como uma forma de prevenção contra recalques do solo (CARNEIRO, 2016; ALMEIDA, 2016).

No projeto piloto Anita Garibaldi, com apenas 20 unidades habitacionais, tentou-se introduzir uma tecnologia construtiva inovadora. O conjunto foi construído utilizando um "tijolo ecológico", feito a partir da reciclagem de resíduos de construção, misturados com cimento, que apresentava um bom acabamento sem a necessidade de argamassas de revestimento, resultando em redução de custos (Figura 4). Outros projetos até chegaram a ser adequados ao módulo construtivo do tijolo ecológico, contudo, problemas entre o único fabricante do produto em Fortaleza e à HABITAFOR levaram ao abandono do uso dessa tecnologia pelo órgão.

Figura 4 - Conjunto Anita Garibaldi, antes da entrega às famílias (2006)

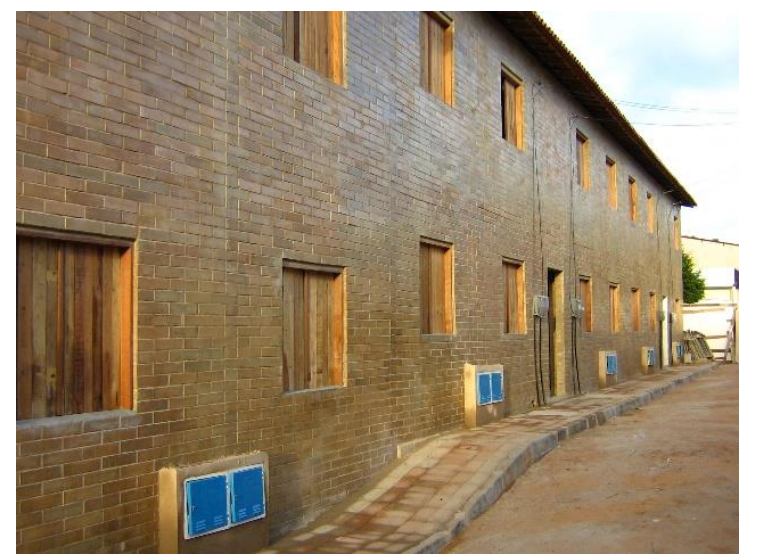

Fonte: HABITAFOR (2006)

Relacionada à diretriz de "Segurança, salubridade e qualidade da edificação", a proibição de realização de alterações construtivas nas unidades habitacionais, sem autorização da HABITAFOR, em razão da utilização da alvenaria estrutural, gerou algumas situações de perigo iminente, pois mesmo com a proibição, alguns moradores insistiram em executar obras, inclusive com abertura de vãos nas paredes. A rápida deterioração observada nos blocos habitacionais e nas áreas urbanizadas aponta não só para uma baixa qualidade das obras, como também para a inexistência de uma política de manutenção das intervenções implementadas pela prefeitura. 
Nas intervenções concebidas pela HABITAFOR, especialmente naquelas em que a tipologia habitacional adotada foi o bloco de apartamentos, não estava prevista a "Possibilidade de ampliação das unidades habitacionais". O resultado foi que praticamente em todos os conjuntos, houvesse modificações nas unidades

Quanto à "Compatibilidade do projeto com características regionais, locais, climáticas e culturais", não havia exatamente uma intenção de se perseguir essa diretriz do MCidades na adoção pela HABITAFOR da alvenaria e telhas cerâmicas em seus projetos. Apesar de serem materiais tradicionalmente utilizados na região, essa opção se deu muito mais em razão da redução no custo das obras (CARNEIRO, 2016).

A não adoção de outros elementos arquitetônicos, como varandas e janelas do tipo veneziana, que seriam opções bem adequadas ao clima e à tradição construtiva local, tem a mesma justificativa na redução dos custos. Até mesmo questões como ventilação e iluminação naturais, apesar de consideradas pelos projetistas, costumavam ser sobrepujadas pela necessidade de se implantar o maior número de unidades habitacionais possível nos terrenos trabalhados pela HABITAFOR (HATSUE, 2016).

O tema da "Acessibilidade" em projetos de habitação de interesse social constituía uma novidade para a Prefeitura de Fortaleza. Na visão de Almeida (2016), ex-arquiteto da HABITAFOR, "na questão de acessibilidade não tinha um direcionamento, pelo menos não formal, se o arquiteto quisesse fazer, ele fazia”. Almeida relembra ainda que em alguns projetos foram feitos ajustes, como no projeto Casa e Renda (Figura 5), por problemas com o levantamento topográfico, que geralmente costumava chegar para os técnicos após a definição do partido urbanístico, ou por demandas identificadas pela equipe de trabalho social da HABITAFOR, como na Maravilha, onde inicialmente não havia previsão de unidades adaptadas para pessoas com deficiência física.

De modo geral, o uso de rampas de acesso às calçadas e para as unidades habitacionais nos projetos foi a solução adotada para viabilizar a acessibilidade às unidades habitacionais. Quanto ao dimensionamento das calçadas, a LUOS estabelecia, em seu Anexo 4, que as vias internas dos projetos poderiam ter uma largura total de 6 metros, sendo um passeio de $1,70 \mathrm{~m}$ para receber o posteamento e 
o outro com 1,10m. Esta dimensão conflitava com a NBR9050 da ABNT, que recomenda um mínimo de 1,20m para calçadas acessíveis.

Figura 5 - Rampas de acesso nas calçadas do conjunto Casa e Renda

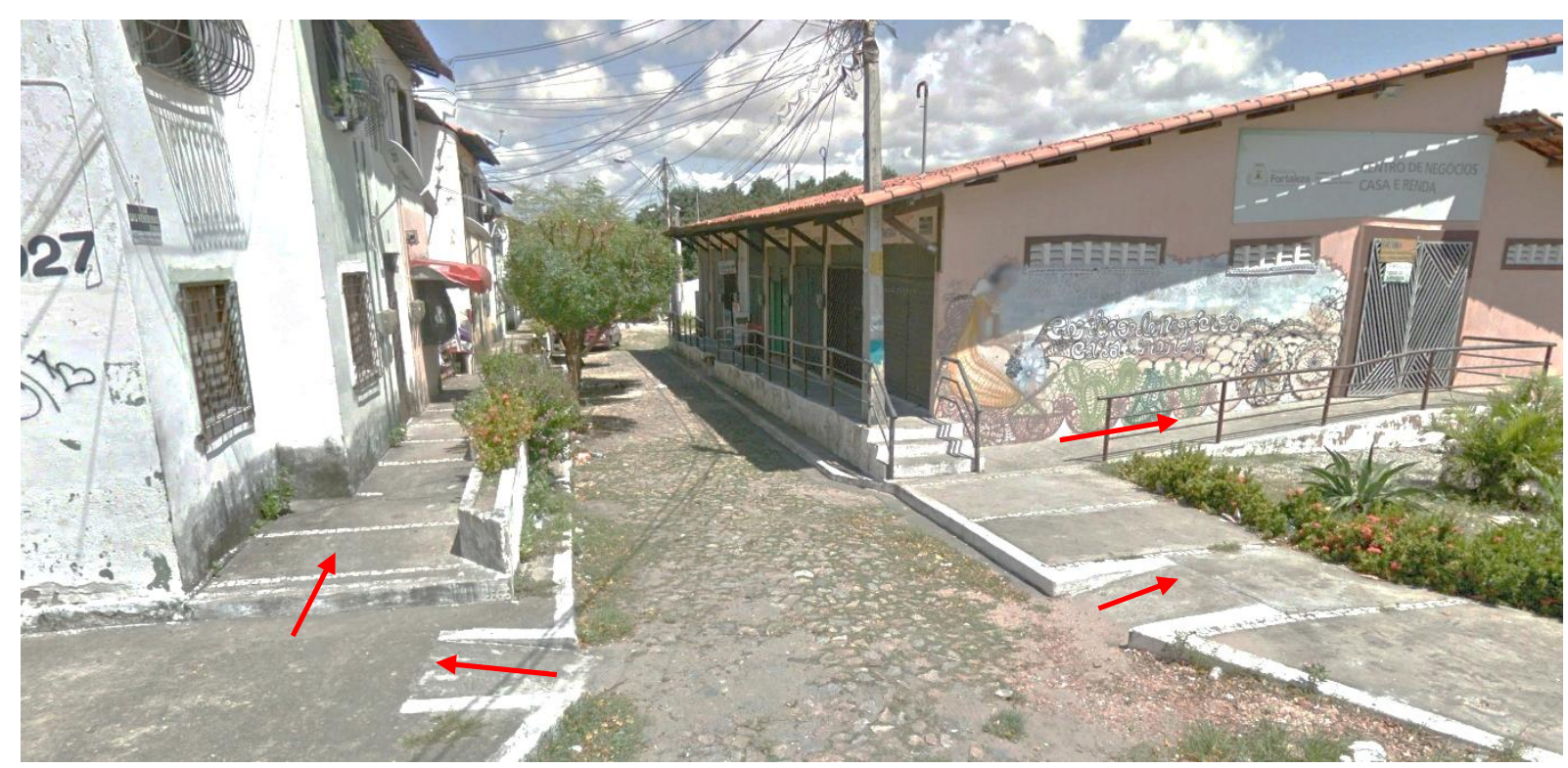

Fonte: Google Earth (2016), adaptação do autor

\subsection{Diretrizes relacionadas à Definição dos Beneficiários}

Através de alguns Planos de Trabalho Técnico Social (PTTS) elaborados por técnicos da prefeitura, aos quais tivemos acesso, foi possível verificar o "Atendimento prioritário à população de menor renda", com foco nas famílias com ganhos de até 3 salários mínimos. Contudo, por responder a demandas fechadas, as intervenções também poderiam incluir famílias com renda maior.

A renda média das famílias na intervenção PREURBIS-Cocó era de aproximadamente 1,5 salário mínimo, à época da realizado do diagnóstico social (FORTALEZA, 2010). $\mathrm{Na}$ comunidade do Pau Fininho, alvo da intervenção na Lagoa do Papicu, 100\% das famílias se enquadravam na faixa de renda de até 3 salários mínimos (FORTALEZA, 2007), assim como na intervenção São Cristóvão / Campo Estrela (FORTALEZA, s/d). Em seu estudo sobre o conjunto Maria Tomásia, o reassentamento para as famílias das áreas da Lagoa da Zeza e da Vila Cazumba, Dias (2013) traz o dado de 89\% das famílias entrevistadas possuindo renda de até 2 salários mínimos. Por sua vez, Freitas 
(2014) destaca em sua pesquisa sobre a intervenção Maravilha que 70\% das famílias entrevistadas também afirmaram receber até 2 salários mínimos.

Não havia o "Estabelecimento de quotas para atendimento a idosos (3\%), deficientes (3\%) e famílias chefiadas por mulheres", pela mesma justificativa de que as intervenções, em geral, trabalhavam com demandas fechadas de comunidades. Portanto, o atendimento a esse público não estava condicionado a cotas previamente estabelecidas, mas ao diagnóstico social elaborado pela equipe técnica da HABITAFOR. Contudo, o problema da desarticulação entre os trabalhos social e de arquitetura e engenharia resultava em projetos que, geralmente, não atendiam completamente à demanda levantada, que costuma chegar posteriormente à concepção das intervenções. Alguns projetistas ainda realizavam adaptações à demanda social, quando possível (ALMEIDA, 2016).

No que se refere à diretriz de atendimento prioritário à "População residente em áreas sujeitas a fatores de risco", como já foi visto ao longo desse trabalho, até 2012, este era o principal foco das intervenções implementadas pela HABITAFOR. Com o advento do PMVMV, com foco na provisão habitacional e a seleção das famílias por meio de sorteios, as intervenções passaram a não considerar as áreas de risco na sua totalidade, havendo apenas a remoção de uma ou outra família "premiada". A política habitacional é transfigurada em loteria da sorte.

A Fundação João Pinheiro define a coabitação familiar como aquelas famílias conviventes que têm intenção de constituir domicílio exclusivo e o ônus excessivo com aluguel corresponde ao número de famílias com renda até três salários mínimos que despendem $30 \%$ ou mais de sua renda com o aluguel de sua moradia (FUNDAÇÃO JOÃO PINHEIRO, 2013). Mesmo atendendo a demandas fechadas, as intervenções da HABITAFOR acabaram atendendo a diretriz "Atendimento à população com problemas de coabitação familiar ou ônus excessivo com aluguel", conforme os conceitos adotados pelo MCidades, especialmente no que se refere à coabitação.

Quanto à questão do ônus excessivo com aluguel, não nos foi possível, através da documentação levantada, verificar esse atendimento, pois os diagnósticos sociais ao quais tivemos acesso, referiam-se apenas ao número de famílias em situação aluguel, sem realizar o cruzamento com dados de renda. Contudo, considerando a renda 
dessas famílias, que poucas vezes ultrapassavam os três salários mínimos, podemos conjecturar que a probabilidade da presença do ônus excessivo com aluguel entre aquelas atendidas pelas intervenções é alta.

Na intervenção Lagoa da Zeza / Vila Cazumba, o PTTS apontava 13,61\% das famílias em situação de coabitação na área da Vila Cazumba, registrando casos de quatro 4 famílias conviventes no mesmo imóvel (FORTALEZA, 2006). No caso da Lagoa do Papicu, foi detectada a coabitação em 4,91\% dos domicílios (FORTALEZA, 2007). Por sua vez, Freitas (2014) chama atenção para o fato da prática da coabitação ter sido novamente empregada na Maravilha e no conjunto Maria Tomásia, demonstrando que as intervenções habitacionais não foram capazes de solucionar plenamente o problema.

Por fim, a última diretriz do MCidades que analisada foi a "Contribuição das famílias beneficiadas, sempre que possível". Nas intervenções da HABITAFOR, as unidades habitacionais eram cedidas para as famílias gratuitamente, por meio dos termos de Concessão de Direito Real de Uso. Diferentemente, no PMCMV, as famílias atendidas pela Faixa 1, que possuem renda entre zero e três salários mínimos, passaram a pagar prestações que the conferem o direito à propriedade ao final do prazo estabelecido. Contudo, mesmo com os altos subsídios garantidos pelo governo federal, que permitem valores extremamente baixos para as prestações, foram verificados percentuais de inadimplência de $70 \%$ ou mais em alguns conjuntos (ROSA, PEQUENO e SILVA, 2014), o que pode indicar uma dificuldade para as famílias com renda menor que um salário mínimo em arcar com este ônus. 
Habitação social em Fortaleza (CE) pós Ministério das Cidades / Capítulo 03 - Página | 125

CAPÍTULO 03 - ANÁLISE DE INSERÇÃO URBANA 
A realização de avalições para a verificação das condições de habitabilidade em edificações voltadas para a moradia é antiga no Brasil, com as primeiras pesquisas surgindo na década de 1970, especialmente pela necessidade de se refletir sobre a massiva produção habitacional realizada no período do BNH (GALVÃO, ORNSTEIN e ONO, 2013).

Diversos são os métodos e instrumentos de avaliação de projetos e obras em arquitetura com ênfase em habitação de interesse social. Contudo, ao observarmos aqueles mais conhecidos, como os certificados Leed - Leadership in energy and environmental design ${ }^{71}$, AQUA - Alta Qualidade Ambiental ${ }^{72}$, ou o Selo Casa Azul da $\mathrm{CAIXA}^{73}$, percebemos um maior foco na questão da sustentabilidade dos processos construtivos das edificações (KOWALTOWSKI, GRANJA, et al., 2013), preterindo a análise dos conjuntos habitacionais na escala urbana.

Mais recentemente, tendo em vista a intensa produção habitacional promovida pelo o PMCMV, as pesquisas têm buscado incorporar aspectos relativos à inserção urbana dos conjuntos habitacionais, relacionando-os à cidade e ao bairro. Diversos estudos foram produzidos considerando este aspecto, como apresentado nos livros "Produzir casas ou construir cidades?" (FERREIRA, 2012) e "Minha casa... e a cidade?" (AMORE, SHIMBO e RUFINO, 2015).

Neste capítulo, aprofundaremos o estudo sobre as intervenções implementadas pela HABITAFOR após MCidades, através da análise da inserção urbana da intervenção Maravilha e do conjunto Maria Tomásia, reassentamento da intervenção de urbanização da Lagoa da Zeza e Vila Cazumba. A escolha dos estudos de caso advém da intenção de estabelecermos uma comparação entre duas intervenções com

\footnotetext{
71 O Leed é constituído de um checklist que "inclui os seguintes tópicos: sítios sustentáveis, redução do uso de água (utilizá-la de modo eficiente), aspectos de energia e qualidade do ar, materiais e recursos, qualidade do ar interno e processo de projeto e suas inovações" (KOWALTOWSKI, GRANJA, et al., 2013, p. 165).

72 O processo AQUA "analisa o sistema de gestão do empreendimento e a qualidade ambiental do edifício [...] sob os aspectos de: relação do edifício com o seu entorno; escolha integrada de produtos, sistemas e processos construtivos; canteiro de obras com baixo impacto ambiental; gestão da energia, água e de resíduos de uso e operação do edifício; manutenção/permanência do desempenho ambiental; conforto higrotérmico, acústico, visual e olfativo; qualidade sanitária dos ambientes, do ar e da água" (KOWALTOWSKI, GRANJA, et al., 2013, p. 159).

7373 No caso do Selo Casa Azul, promovido pela CAIXA, são considerados "os principais impactos socioambientais da cadeia produtiva da construção, com critérios e procedimentos de avaliação para obtenção do selo" (KOWALTOWSKI, GRANJA, et al., 2013, p. 170).
} 
localizações distintas na cidade, a Maravilha, implantada próxima da área central, e o Maria Tomásia, em área mais distante, próxima do limite sul de Fortaleza.

Inicialmente, com base nas informações obtidas junto à HABITAFOR, realizamos uma apresentação de ambas as intervenções, de modo a compreender seus processos de implementação. No segundo momento, apoiado em Ferreira (2012) e na "Ferramenta de avaliação de inserção urbana para os empreendimentos de faixa 1 do programa Minha Casa Minha Vida" (LABCIDADE e ITDP, 2014), adaptamos uma metodologia para a análise de inserção urbana dos conjuntos de acordo com os seguintes eixos temáticos: localização, mobilidade, infraestrutura, serviços urbanos e fluidez urbana.

\subsection{A intervenção na Maravilha}

A ocupação da área da comunidade Maravilha (Mapa 21 e Figura 6), localizada no bairro de Fátima, remonta ao início dos anos 1960. De forma espontânea, lenta e desorganizada, os primeiros moradores se instalaram nas proximidades do ramal ferroviário Parangaba-Mucuripe, expandindo-se posteriormente para a área mais próxima ao riacho Tauape, que costumava causar inundações nos períodos de chuvas (BORGES, 2012; ARAUJO, 2013; FREITAS, 2014).

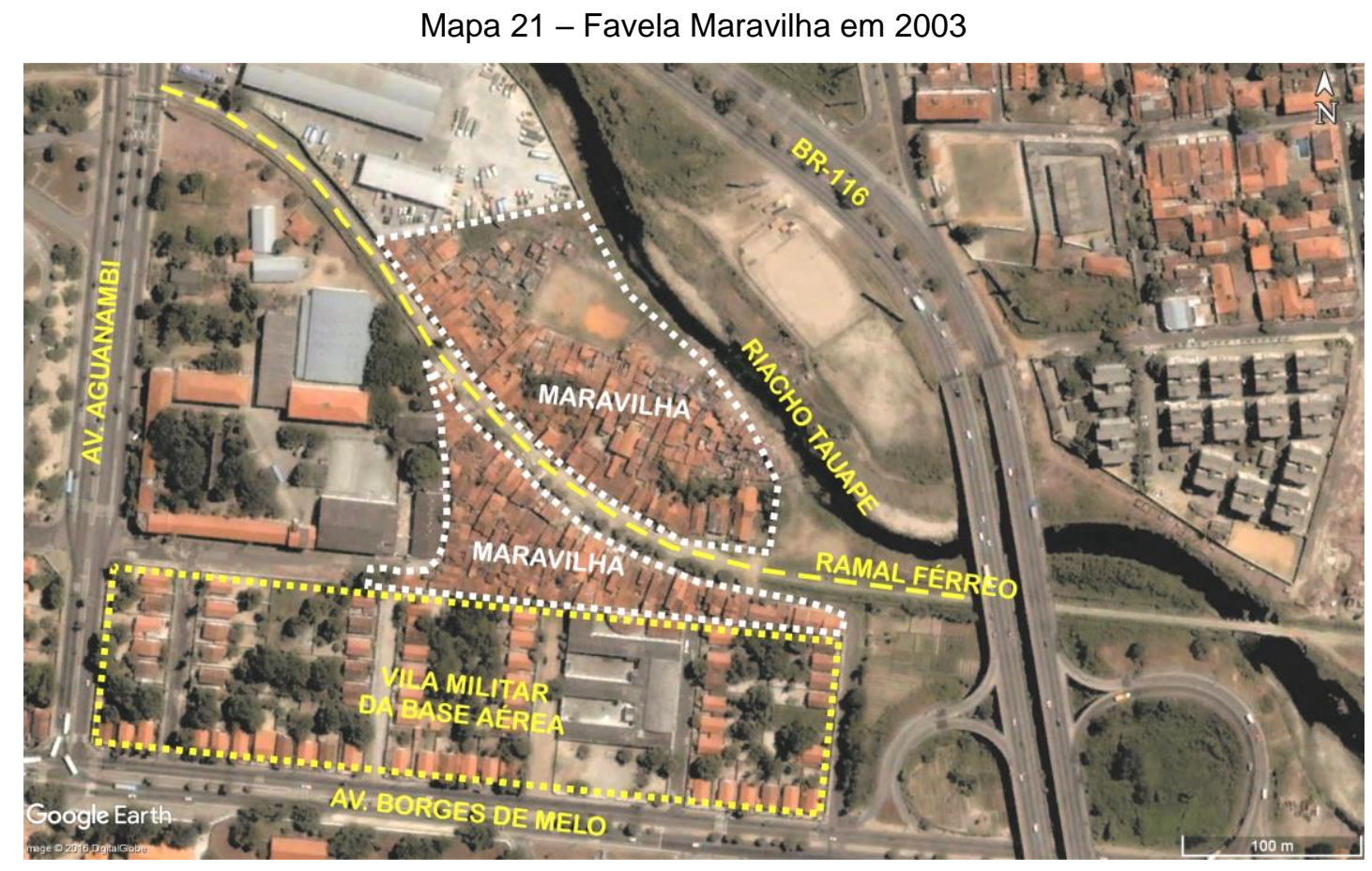

Fonte: HABITAFOR e Google Earth, adaptado pelo autor 
Figura 6 - Comunidade Maravilha e o Riacho Tauape antes da intervenção

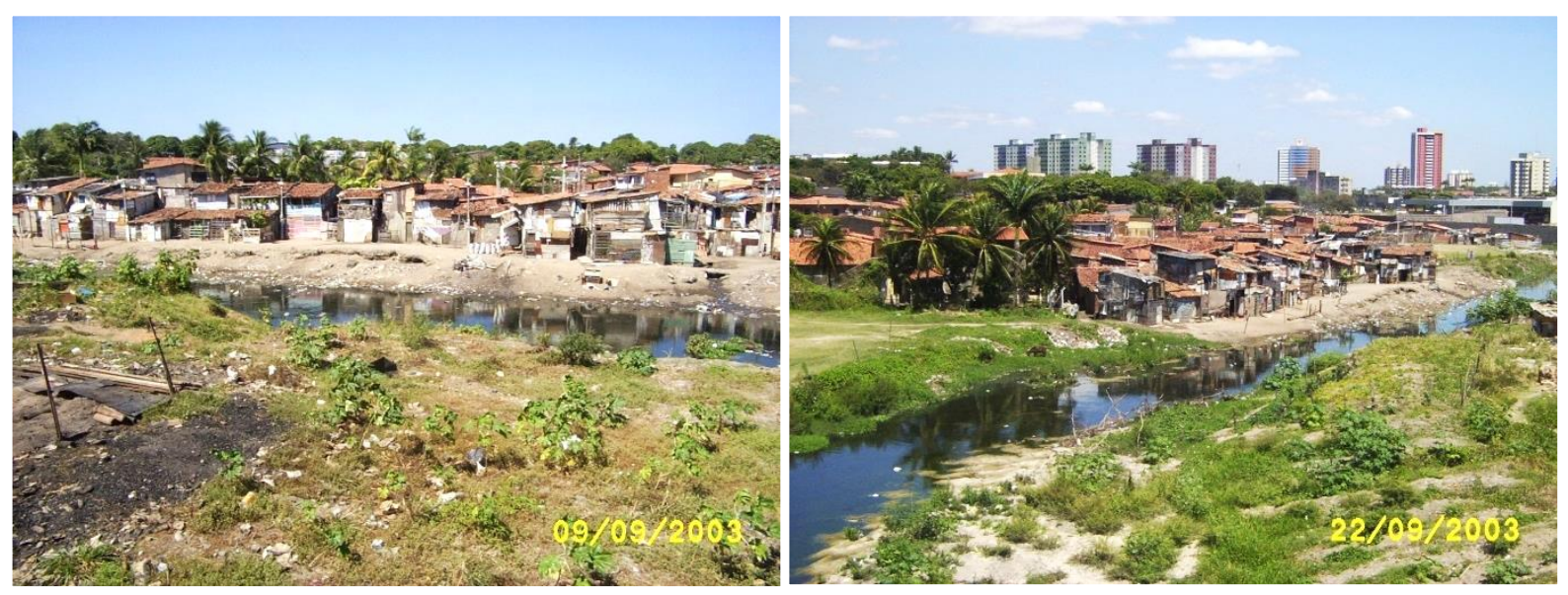

Fonte: HABITAFOR

Outra dificuldade desse período foi organizar a resistência às demolições que os militares da Base Aérea de Fortaleza perpetravam aos ocupantes da Maravilha. Entretanto, com [o] tempo, a comunidade foi se diversificando e aprendendo a lidar com a Base Aérea, mantendo-se na localidade e findando com a instituição militar cedendo o terreno contíguo à sua área (FREITAS, 2014, p. 80).

Por meio de muita luta e resistência dos moradores, a favela Maravilha persistiu e foi crescendo. Em 1974, chegou a energia elétrica, através do Plano de Extensão da COELCE e o abastecimento de água, solicitado à CAGECE em 1984, veio em 1989 (FREITAS, 2014).

Como vimos no primeiro capítulo, apesar de sua classificação em 16 posição na hierarquização das áreas de risco do PEMAS, a Maravilha foi selecionada para ser a segunda área, a Lagoa do Opaia havia sido a primeira, para receber recursos pelo Programa Habitar Brasil-BID (PHBB) destinados à realização de uma intervenção integrada. Assim, por meio do Subprograma de Urbanização de Assentamentos Subnormais, a prefeitura contratou o escritório Espaço Plano - Arquitetura e Consultoria S/S Ltda. para a elaboração do projeto.

Ainda antes da licitação das obras, ocorrida apenas em 2007, várias alterações de projeto foram realizadas pela própria equipe da HABITAFOR, durante a gestão de Olinda Marques no órgão. Algumas mudanças se deram em razão da necessidade de adequar o orçamento das obras, que ultrapassava o valor do contrato de repasse com o governo federal (RODRIGUES, 2016), com a substituição de alguns elementos por outros de menor preço, como as janelas do tipo veneziana trocadas por tipo ficha. Outras mudanças ocorreram para adequar o projeto a demandas identificadas pelo 
setor social da HABITAFOR, como a necessidade de apartamentos com banheiros adaptados, ou a demandas externas, como as alterações solicitadas pela Secretaria Municipal de Educação no projeto da creche/escola (ALMEIDA, 2016). Também ocorreram adequações no projeto em razão de circunstâncias de obra, como a mudança na implantação de blocos habitacionais no Setor II para possibilitar a continuidade das obras, enquanto corriam negociações para indenização de alguns imóveis existentes no terreno.

A intervenção Maravilha (Mapa 22 e Figura 7) abrangeu a construção de 606 unidades habitacionais divididas da seguinte maneira: 144 apartamentos, em blocos de 2 pavimentos, no conjunto Planalto Universo, o reassentamento da intervenção na Lagoa do Opaia; 174 apartamentos, no Setor I; 90 apartamentos, no Setor II; e 198 apartamentos, no Setor III. Nestes três setores, os blocos possuem 3 pavimentos, com os Setores I e II localizados na própria área da comunidade e o Setor 3 localizado em terreno do outro lado da rodovia BR-116, que após a mudança das famílias passou a ser chamado de Conjunto Nossa Senhora de Fátima.

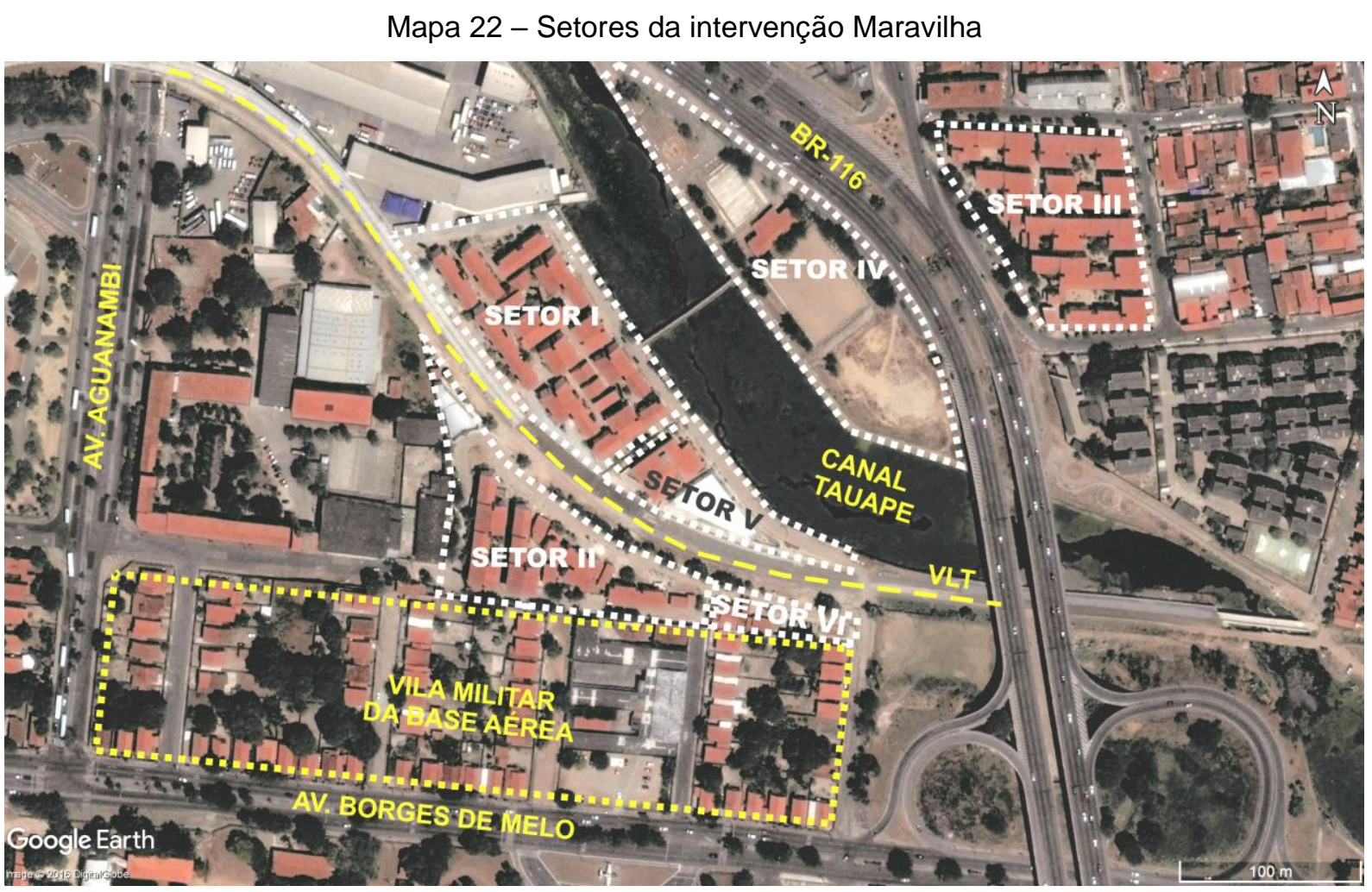

Fonte: HABITAFOR e Google Earth, adaptado pelo autor 
Figura 7 - Maravilha Setor I (esq.) e Setor II (dir.)

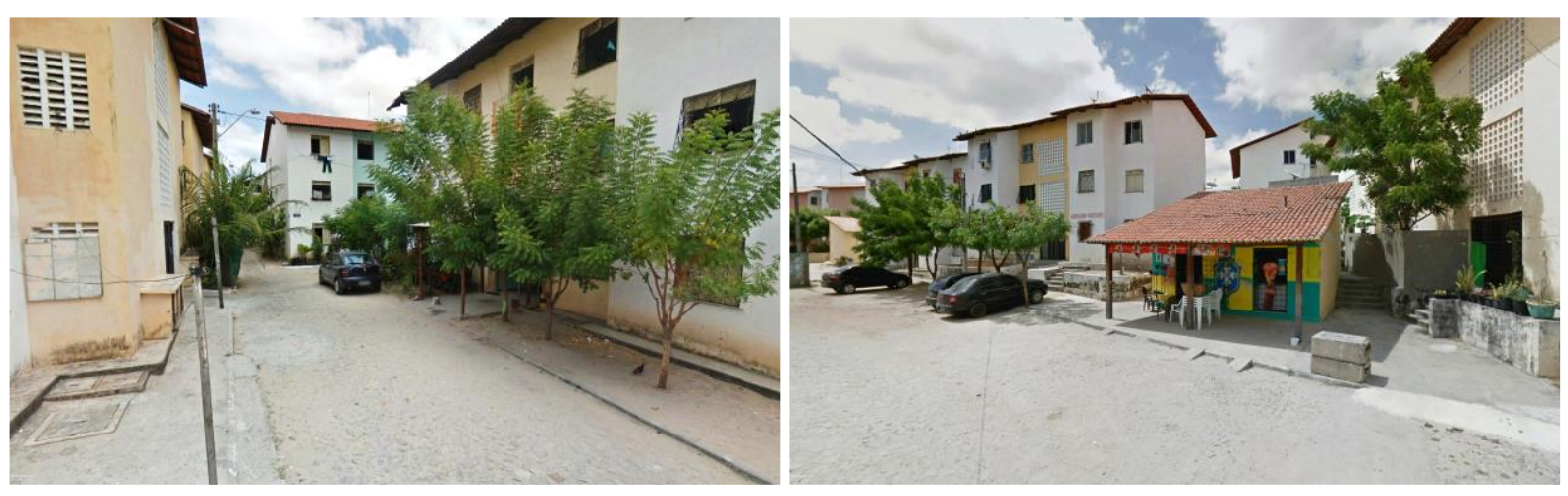

Fonte: Google Earth (2015)

Também foram construídos equipamentos esportivos e de lazer, no Setor IV (Figura 8), o Centro de Ensino Infantil e Ensino Fundamental Madre Teresa de Calcutá, e o centro comunitário para a Associação dos Moradores e Amigos da Maravilha, que funciona ao lado do equipamento educacional, no Setor V.

\section{Figura 8 - Equipamentos esportivos no Setor IV e Setor III ao fundo}

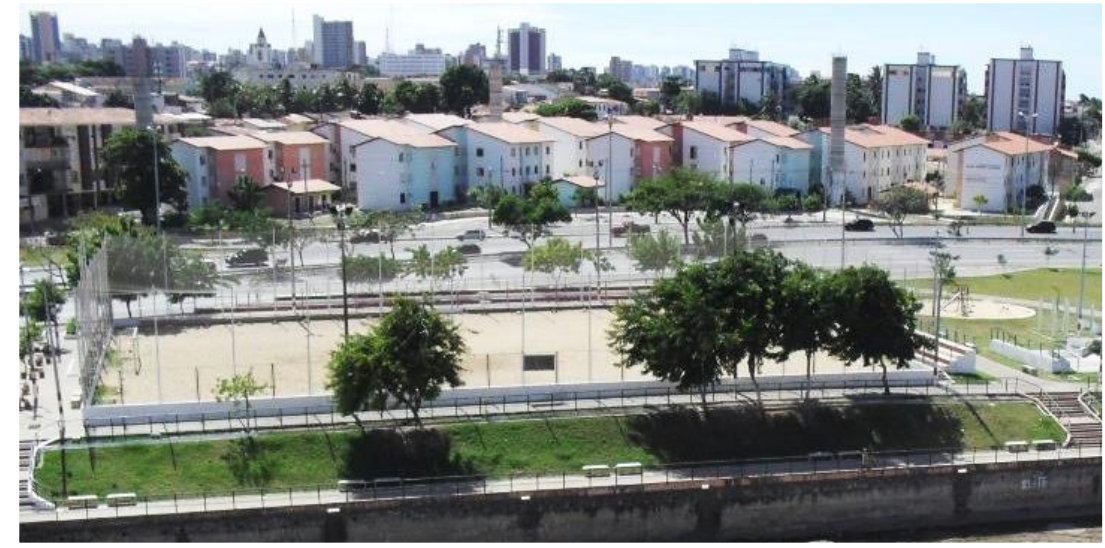

Fonte: HABITAFOR

\subsection{0 conjunto Maria Tomásia}

No primeiro capítulo deste trabalho, vimos que a atuação da HABITAFOR, no início da gestão de Olinda Marques no órgão, em 2005, procurou vincular as intervenções à hierarquização das áreas de risco do PEMAS. Nesse período, havia uma situação de escassez de recursos para a implementação de ações. A concepção da intervenção de urbanização da Lagoa da Zeza e da Vila Cazumba, da qual o Maria Tomásia constituiu o reassentamento para as famílias a serem removidas, está relacionada a esse cenário. 
Ainda em 2005, a Secretaria de Patrimônio da União (SPU) disponibilizou recurso para a HABITAFOR utilizar em ação habitacional que envolvesse terrenos da União. Para isso, era preciso gastar o recurso até o final do ano, pois a rubrica orçamentária seria zerada no ano seguinte (RODRIGUES, 2016). Como havia de ser pagamento imediato, a HABITAFOR resolveu aplicar o recurso na aquisição de terreno e, assim, foi adquirido o terreno onde posteriormente foi construído o conjunto Maria Tomásia (RODRIGUES, 2016).

Restava a condição de que a aplicação do recurso estivesse vinculada a problemas habitacionais em terrenos da União. Aproveitando-se do programa "Palafitas-Zero", recém-lançado pelo governo federal, que por meio do programa de "Urbanização, Regularização e Integração de Assentamentos Precários" focava-se em áreas de ocorrência de palafitas, principalmente a região Norte do Brasil, a equipe da HABITAFOR elaborou uma justifica técnica mostrando a existência desse tipo de moradia em Fortaleza, vinculada a áreas de lagoas que seriam da União (RODRIGUES, 2016) e conseguiu captar recurso junto ao Ministério das Cidades para desenvolver intervenções. As áreas selecionadas foram a Lagoa da Zeza ${ }^{74}$ (Figura 9) e a Vila Cazumba (Figura 10), que, além de apresentarem palafitas, estavam classificadas na hierarquização das áreas de risco do PEMAS em $27^{\circ}$ e $14^{\circ}$ lugares, respectivamente ${ }^{75}$.

\section{Figura 9 - Ocupações na Lagoa da Zeza}

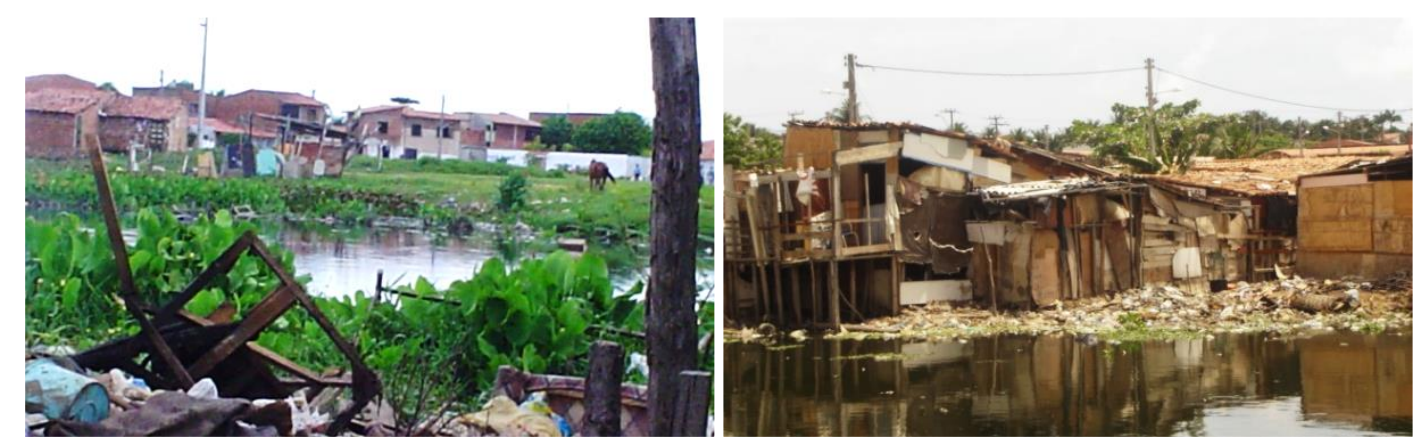

Fonte: HABITAFOR

\footnotetext{
${ }^{74}$ Nos anos 1990, a área da Lagoa da Zeza fora objeto de intervenção por parte do governo do estado, por meio do programa Pró-Moradia, que incluiu também a Lagoa do Tijolo, localizada um pouco mais ao norte da Zeza, enquanto a Cazumba se localiza ao sul da Zeza.

75 Outras áreas de risco da hierarquização do PEMAS também foram trabalhadas, como o Gato Morto / Tancredo Neves, a primeira da lista, que foi trabalhada pelo governo do estado, ainda no PHBB, ou a

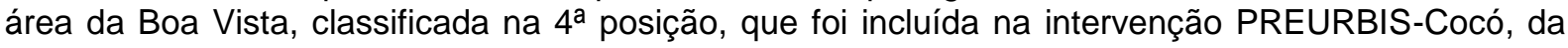
prefeitura, entre outras.
} 
Figura 10 - Ocupações na Vila Cazumba

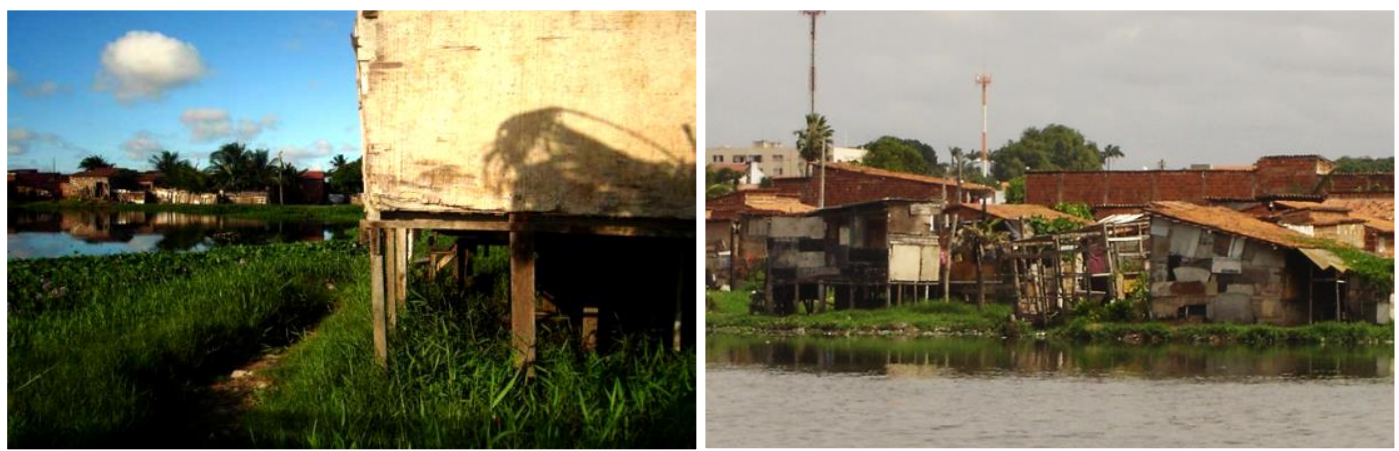

Fonte: HABITAFOR

Portanto, o conjunto habitacional Maria Tomásia tem origem como o reassentamento das famílias a serem removidas das áreas de risco e de preservação permanente (APP) das lagoas (Figura 11) e daquelas cujas casas não possuíam condições mínimas de habitabilidade, segundo os levantamentos realizados pela HABITAFOR e pela empresa contratada para elaborar os projetos, a Engesoft - Engenharia e Consultoria Ltda.

Figura 11 - Situação das lagoas em 2006 em relação às áreas de preservação permanente
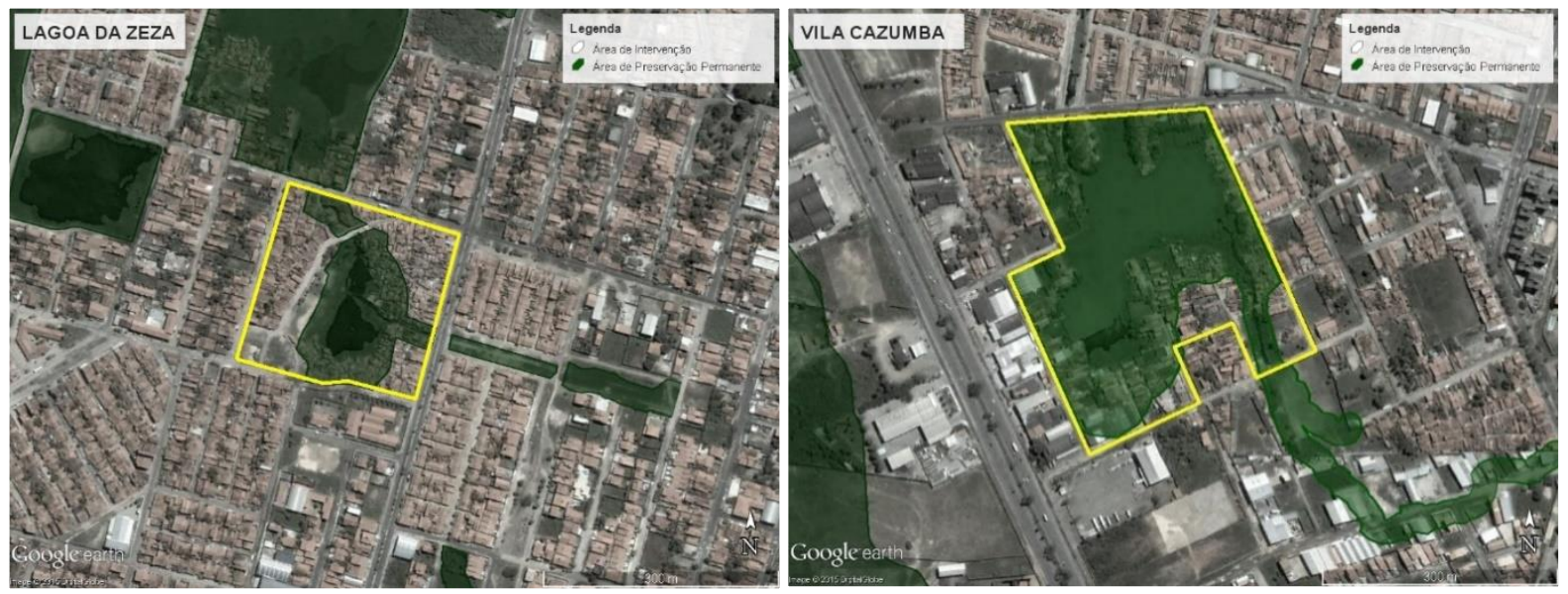

Fonte: HABITAFOR, Plano Diretor Participativo (2009) e Google Earth, elaboração do autor

O conjunto Maria Tomásia possui 1.126 unidades habitacionais, todas casas térreas, com área útil ${ }^{76}$ aproximada de $34 \mathrm{~m}^{2}$, em lotes que variam entre $68 \mathrm{~m}^{2}$ e $104 \mathrm{~m}^{2}$, pois alguns destes apresentam um pequeno recuo frontal. Em termos de arquitetura e

76 Nos referimos à área construída útil como igual à do piso de um compartimento, ou seja, descontando-se as áreas das alvenarias (ALBERNAZ e LIMA, 1997-1998). 
desenho urbano, o conjunto em muito se assemelha à produção habitacional do período do $\mathrm{BNH}$, com sua repetição intensa de uma tipologia padronizada.

Sua localização no bairro Jangurussu, na periferia da região sudeste de Fortaleza, quase no limite com o município de Itaitinga, na região metropolitana, distando mais de $11 \mathrm{~km}$ das áreas de origem, dificultou o deslocamento dos moradores para seus locais de trabalho (DIAS, 2013). Na imagem aérea da Figura 12, tirada ainda antes da entrega do conjunto, podemos perceber a situação de isolamento em que o conjunto estava inserido ${ }^{77}$.

Figura 12 - Foto aérea do conjunto Maria Tomásia e entorno (2008)
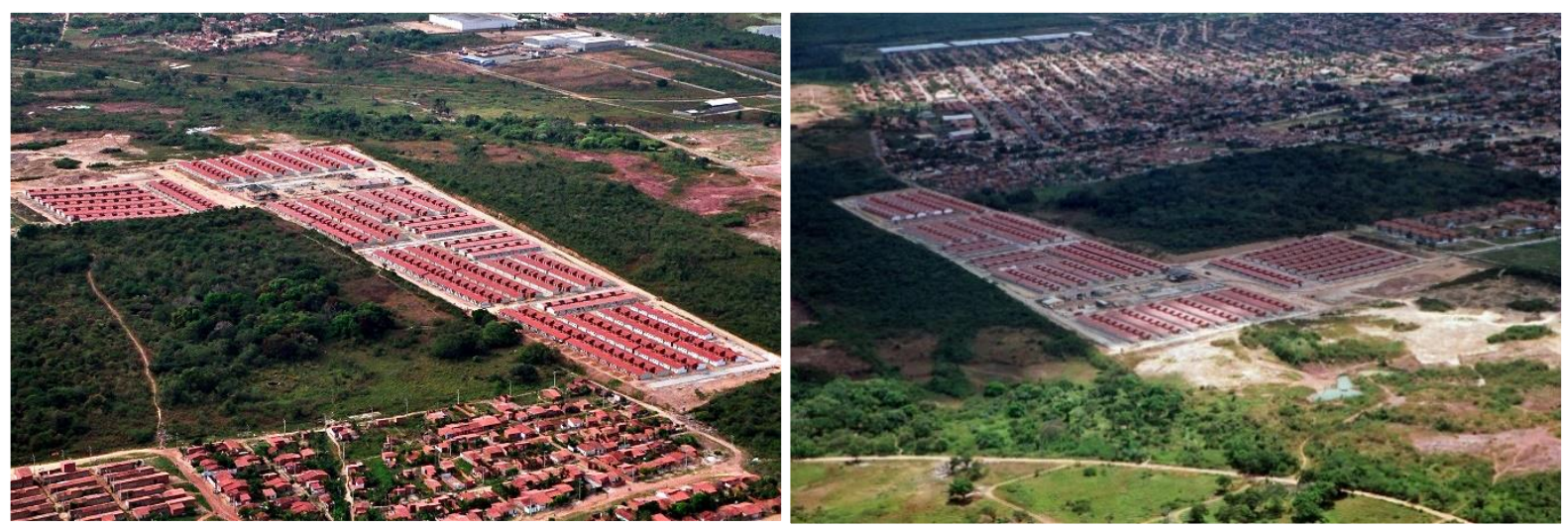

Fonte: HABITAFOR

O memorial descritivo do projeto, atribui a escolha da área à possibilidade de aquisição em tempo hábil de um terreno com dimensões necessárias para receber um grande número de famílias (FORTALEZA, 2007, p. 19), versão que diverge do depoimento de Rodrigues (2016), segundo o qual o terreno fora comprado antes mesmo da concepção da intervenção.

A localização do conjunto, isolado na periferia de Fortaleza, demandou a oferta de equipamentos públicos. Foram construídos uma creche (onde hoje funciona o Centro de Educação Infantil Maria de Jesus Oriá Alencar), um balcão de negócios (ainda sem informações sobre seu funcionamento), duas quadras poliesportivas e uma área com pontos comerciais. Mesmo assim, Dias (2013) apresenta as dificuldades pelas quais os moradores do conjunto passam no tocante ao acesso a equipamentos e serviços

77 Com o Programa Minha Casa Minha Vida a vizinhança do conjunto tem recebido vários empreendimentos habitacionais para a faixa 1 (entre 0 e 3 salários mínimos), reduzindo o isolamento do Maria Tomásia. Fato que não necessariamente se reflete na oferta de serviços e equipamentos públicos. 
públicos, especialmente em relação a vagas em creches para as crianças. Borges (2012) também aponta a distância do conjunto em relação às áreas de origem como um dos fatores que fez do Maria Tomásia um dos conjuntos da HABITAFOR como os maiores números de venda e até de abandono das casas por parte dos moradores.

A não conclusão total das obras possibilitou o surgimento de novos assentamentos precários na vizinhança do conjunto. É possível observar, comparando o projeto com a foto aérea (Figura 13), que duas áreas previstas para serem ocupadas com equipamentos de lazer (manchas verdes na imagem a esquerda) não foram executadas o que possibilitou o surgimento de novas ocupações (delimitadas em vermelho na imagem à direita).

Figura 13 - Projeto original do conjunto Maria Tomásia e as novas ocupações

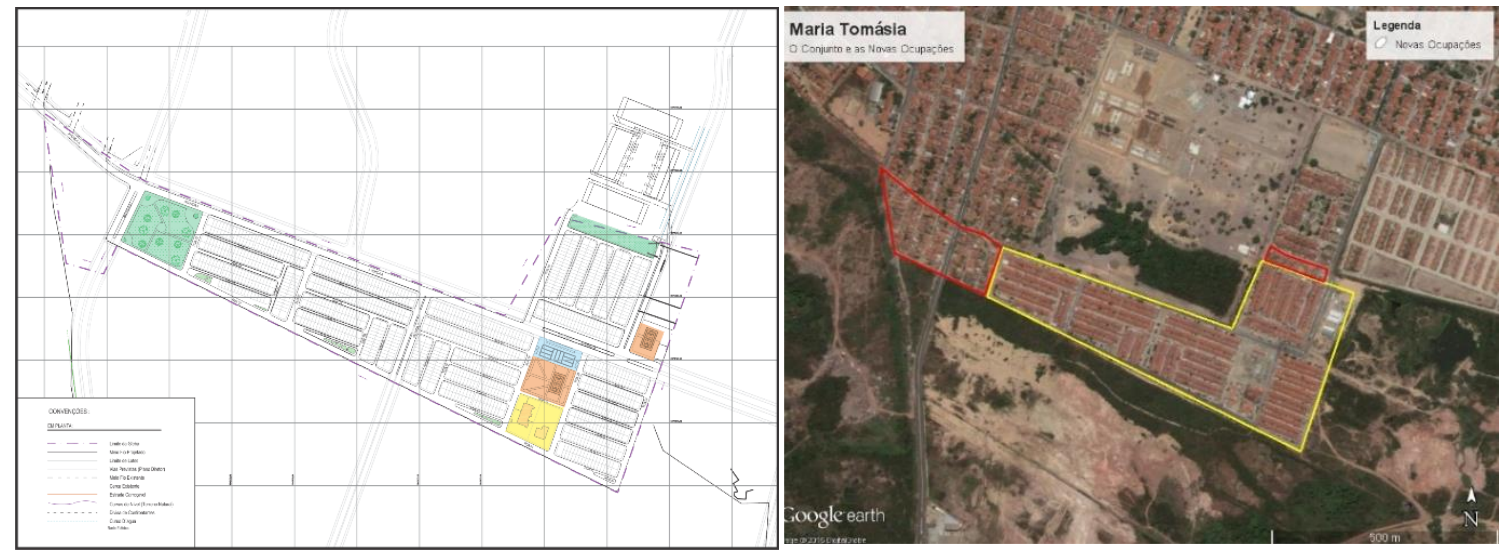

Fonte: HABITAFOR e Google Earth, elaboração do autor

\subsection{Análise de Inserção Urbana}

Após a descrição das intervenções Maravilha e Maria Tomásia, iniciaremos neste item a análise de inserção urbana. Para isto, com o suporte teórico em Ferreira (2012) e no manual desenvolvido pelo LabCidade, da Faculdade de Arquitetura e Urbanismo da USP, em parceria com o Instituto de Políticas de Transporte e Desenvolvimento (LABCIDADE e ITDP, 2014), estabelecemos cinco variáveis a serem investigadas: Localização; Mobilidade; Infraestrutura; Serviços Urbanos; e Fluidez Urbana.

Poderíamos ter descrito a metodologia de análise das variáveis em um capítulo reservado para tal fim ao início do trabalho, mas optamos por apresentá-la junto aos 
resultados, em cada variável, por considerarmos que, desta forma, o texto se torna mais dinâmico e de melhor assimilação para o leitor. Vamos às análises!

\subsubsection{Localização}

Com a variável Localização buscamos analisar o impacto da nova localização das famílias removidas da Maravilha, da Lagoa da Zeza e da Vila Cazumba. Neste item, verificamos a distância e o tempo de deslocamento das famílias de suas áreas de origem para as áreas de reassentamento, bem como em relação a centralidades ${ }^{78}$ de Fortaleza. Foram adotados como referencial de centralidades o bairro Centro e o bairro Messejana, conforme trabalho do Laboratório de Estudos em Habitação da Faculdade de Arquitetura e Urbanismo da Universidade Federal do Ceará (LEHAB, 2015).

Através do software Google Earth, que espacializa dados da Empresa de Transporte Urbano de Fortaleza (ETUFOR) foram medidas as distâncias e o tempo de deslocamento por meio de transporte público, a partir de um ponto estabelecido em cada área. Para realizar a aferição, definimos um ponto central nas áreas de reassentamento e de origem. Já nas centralidades, adotamos pontos de referência relacionados ao sistema de transporte público, o terminal de ônibus da Praça Coração de Jesus, no Centro, e o do bairro Messejana.

Para a distância entre área de reassentamento e áreas de origem, obtivemos o seguinte resultado: na intervenção Maravilha, parte da população foi reassentada no conjunto Planalto Universo, que dista $1,6 \mathrm{~km}$ da área de origem, parte ficou na própria área de origem, nos Setores I e II, e parte foi transferida para o Setor III (conjunto Nossa Senhora de Fátima); na intervenção Lagoa da Zeza e Vila Cazumba, o reassentamento, no conjunto Maria Tomásia, foi implantado a 10,2km de distância (Mapa 23).

\footnotetext{
78 As centralidades são aqui compreendidas como áreas da cidade concentradoras de atividades econômicas que orientam dinâmicas espaciais, assumindo o aspecto de nós nos circuitos do trabalho/produção e do consumo/reprodução nas cidades e estabelecendo conexões e hierarquias (LEHAB, 2015).
} 
Mapa 23 - Distância entre reassentamentos e áreas de origem

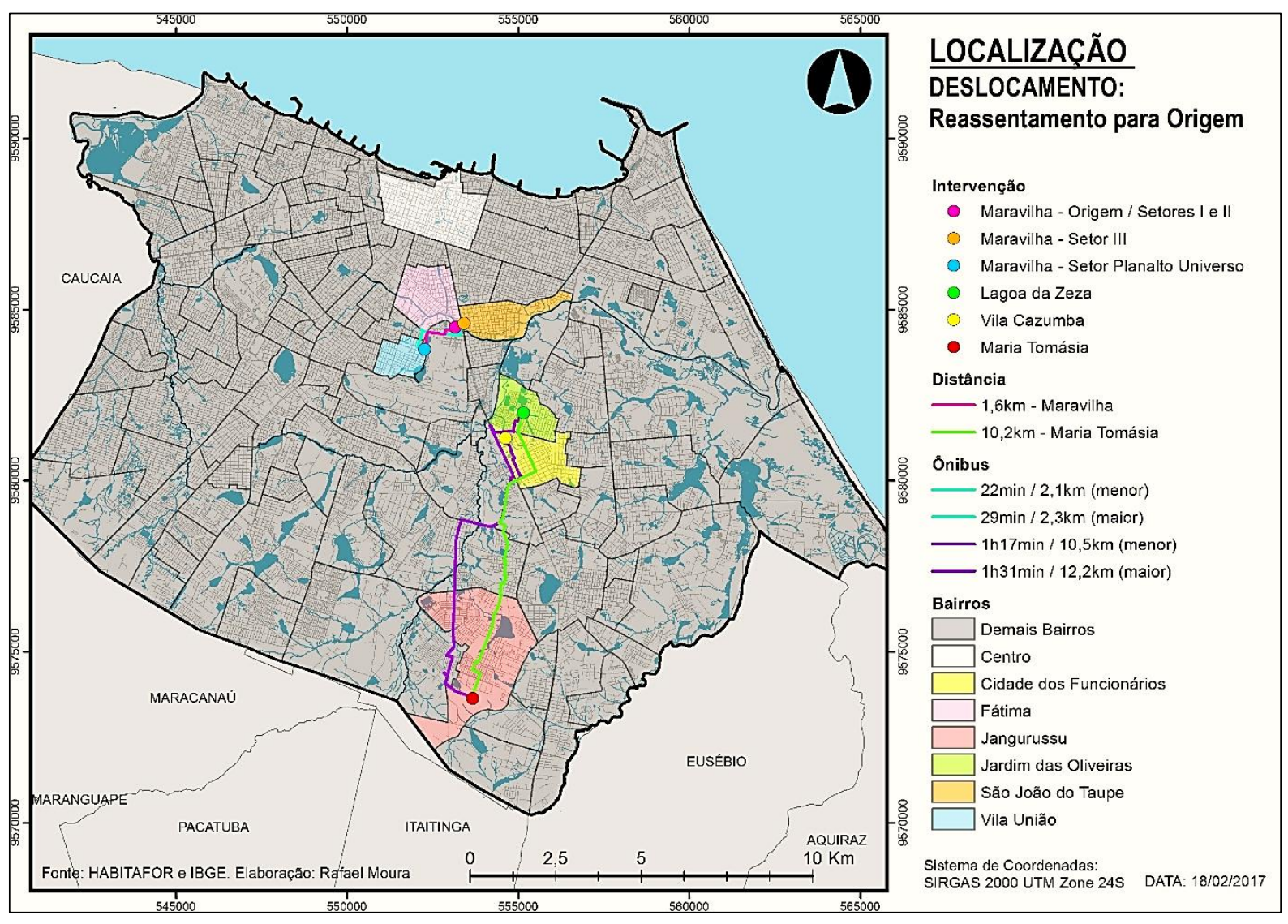

Fonte: HABITAFOR e ETUFOR, apud Google Earth, elaboração do autor

Na Maravilha, apesar da proximidade do Setor III, cerca de 270 metros (em linha reta) para a área de origem, há duas barreiras que dificultam o deslocamento entre ambos os setores: o canal do riacho Tauape, sobre o qual há apenas uma ponte que dá acesso ao Setor IV, onde se localizam os equipamentos esportivos do conjunto; e a BR-116 que torna a travessia demasiadamente perigosa pelo constante fluxo de veículos em velocidade mais alta (ver Mapa 22). Além disso, a linha ferroviária, que está sendo convertida em linha de Veículo Leve sobre Trilhos (VLT), constitui outra barreira a separar os Setores I e II.

Para a classificação das intervenções, no que toca a distância entre os reassentamentos e centralidades em Fortaleza, elaboramos o Quadro 9. A classificação dos resultados, que pode ser vista na Tabela 7, não se pretende definitiva, mas podemos tomá-la como um indicativo de qualidade para a localização das intervenções. 
Quadro 9 - Classificação para a variável Localização

\begin{tabular}{ll}
\hline CLASSIFICAÇÃO & $\begin{array}{l}\text { DISTÂNCIA OU TEMPO DE DESLOCAMENTO } \\
\text { PARA O CENTRO OU SUBCENTRO }\end{array}$ \\
\hline BOM & Diminuição da distância ou do tempo de deslocamento \\
ACEITÁVEL & Manutenção da distância ou do tempo de deslocamento \\
INSUFICIENTE & Aumento da distância ou do tempo de deslocamento \\
\hline
\end{tabular}

Fonte: Elaboração do autor

Para a Maravilha, a análise apresentou três resultados diferentes, de acordo com o setor da intervenção (Tabela 7 e Mapa 24). Para os Setores I e II, a classificação obtida foi “Aceitável”, por terem sido implementados na mesma área de origem das famílias. No caso do Setor III, a distância e o tempo de deslocamento para o centro de Fortaleza chegaram a diminuir, alcançando a classificação "Bom". Contudo, lembramos que, em relação à área de origem, o deslocamento das famílias é prejudicado pela presença da rodovia BR-116, do canal do Tauape e da linha férrea, que atuam como barreiras na escala intraurbana.

Para o caso do conjunto Maria Tomásia, a distância e o tempo de deslocamento para o centro da cidade apresentaram aumentos significativos em relação a suas áreas de origem, Vila Cazumba e Lagoa da Zeza (Tabela 7 e Mapa 24), obtendo a classificação “Insuficiente”. Quando os indicadores são medidos em relação à centralidade do bairro Messejana, a classificação obtida é "Bom”, o que pode atenuar as dificuldades de acesso a equipamentos e serviços por parte dos moradores do conjunto Maria Tomásia.

Tabela 7 - Resultado da análise do indicador Localização em relação a centralidades

\begin{tabular}{lllcc}
\hline INTERVEÇÃOO & $\begin{array}{l}\text { DISTÂNCIA E TEMPO DE } \\
\text { DESLOCAMENTO }\end{array}$ & RESULTADO & CLASSIFICAÇÃO & FONTE \\
\hline \multirow{4}{*}{ Maravilha } & Maravilha - centro & $4,46 \mathrm{~km}$ e $28 \mathrm{~min}$ & - & ETUFOR \\
& Setores I e II - centro & $4,46 \mathrm{~km}$ e $28 \mathrm{~min}$ & ACEITÁVEL & apud \\
& Setor III - centro & $3,9 \mathrm{~km}$ e $25 \mathrm{~min}$ & BOM & Google \\
& Setor PI. Universo - centro & $4,8 \mathrm{~km}$ e 32min & INSUFICIENTE & Earth \\
\hline \multirow{4}{*}{ Maria } & Lagoa da Zeza - centro & $9,0 \mathrm{~km}$ e 46min & - & ETUFOR \\
Tomásia & Vila Cazumba - centro & $9,2 \mathrm{~km}$ e $51 \mathrm{~min}$ & - & apud \\
& Maria Tomásia - centro & $21,7 \mathrm{~km}$ e 1h28min & INSUFICIENTE & Google \\
& Maria Tomásia - subcentro & $7,8 \mathrm{~km}$ e 47min & BOM & Earth \\
\hline
\end{tabular}

Fonte: HABITAFOR, ETUFOR e Google Earth, elaboração do autor 
Mapa 24 - Tempo de deslocamento e distância em relação a centralidades

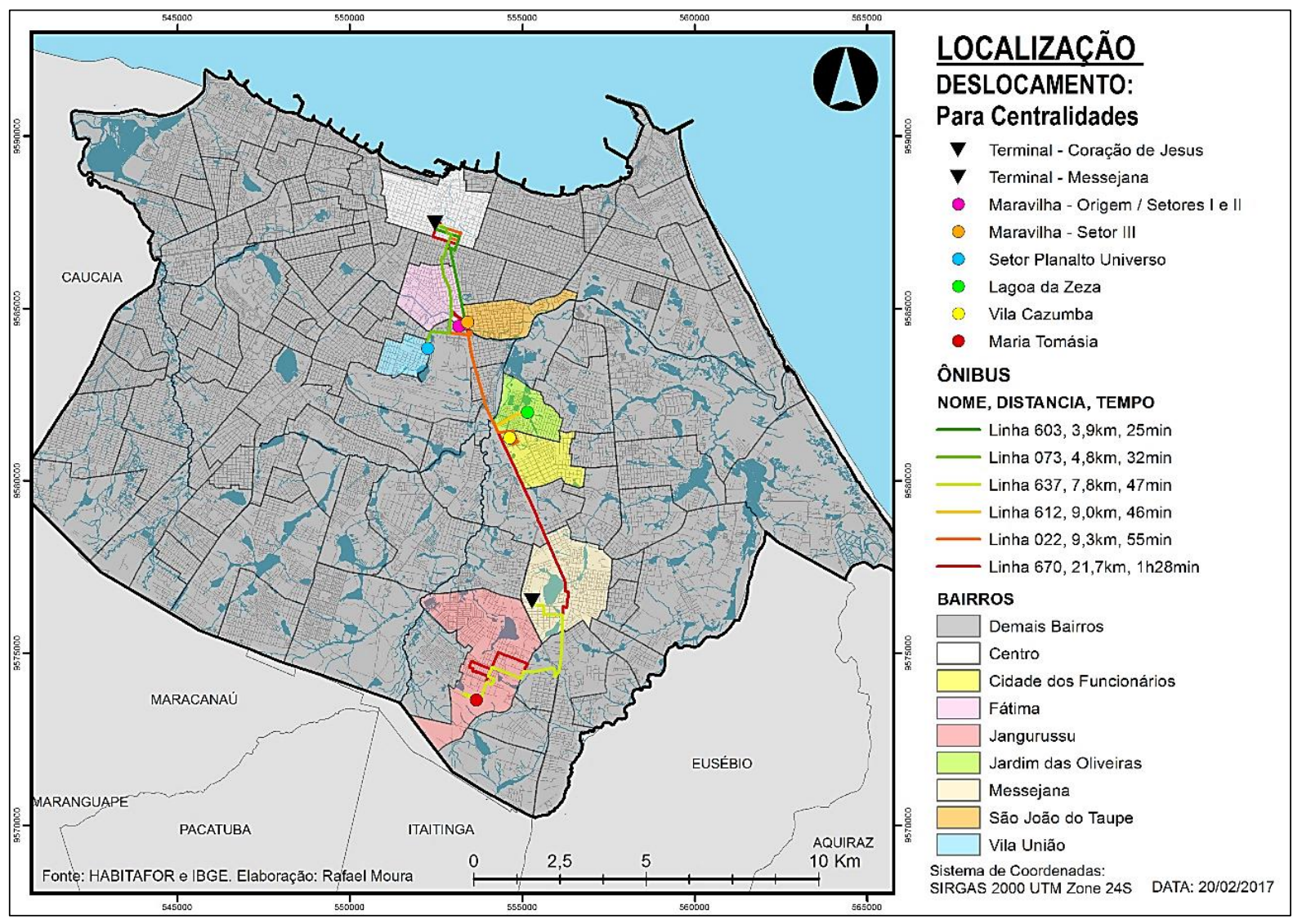

Fonte: HABITAFOR, ETUFOR e Google Earth, elaboração do autor

No Mapa 25, adaptado de LEHAB (2015), podemos observar a localização das duas intervenções aqui estudadas em relação aos centros e subcentros na Região Metropolitana de Fortaleza, que complementa nossa análise.

Observamos que a inserção da Maravilha, além da maior proximidade ao Centro da cidade, dá-se em uma área de bairros considerados centrais, no que se refere à concentração de atividades não residenciais. Podemos deduzir uma maior possibilidade de acesso a equipamentos e serviços urbanos, que procuramos demonstrar mais adiante, com os demais indicadores.

Mesmo as áreas da Lagoa da Zeza e Vila Cazumba, apesar de mais distantes do Centro, em relação à Maravilha, ainda possuem uma localização mais próxima dessas atividades. Isto indica uma piora paras as famílias que se mudaram para o conjunto Maria Tomásia, cuja a centralidade mais próxima é o bairro de Messejana, considerado um subcentro histórico de Fortaleza (LEHAB, 2015). 
Mapa 25 - Centralidades na Região Metropolitana de Fortaleza

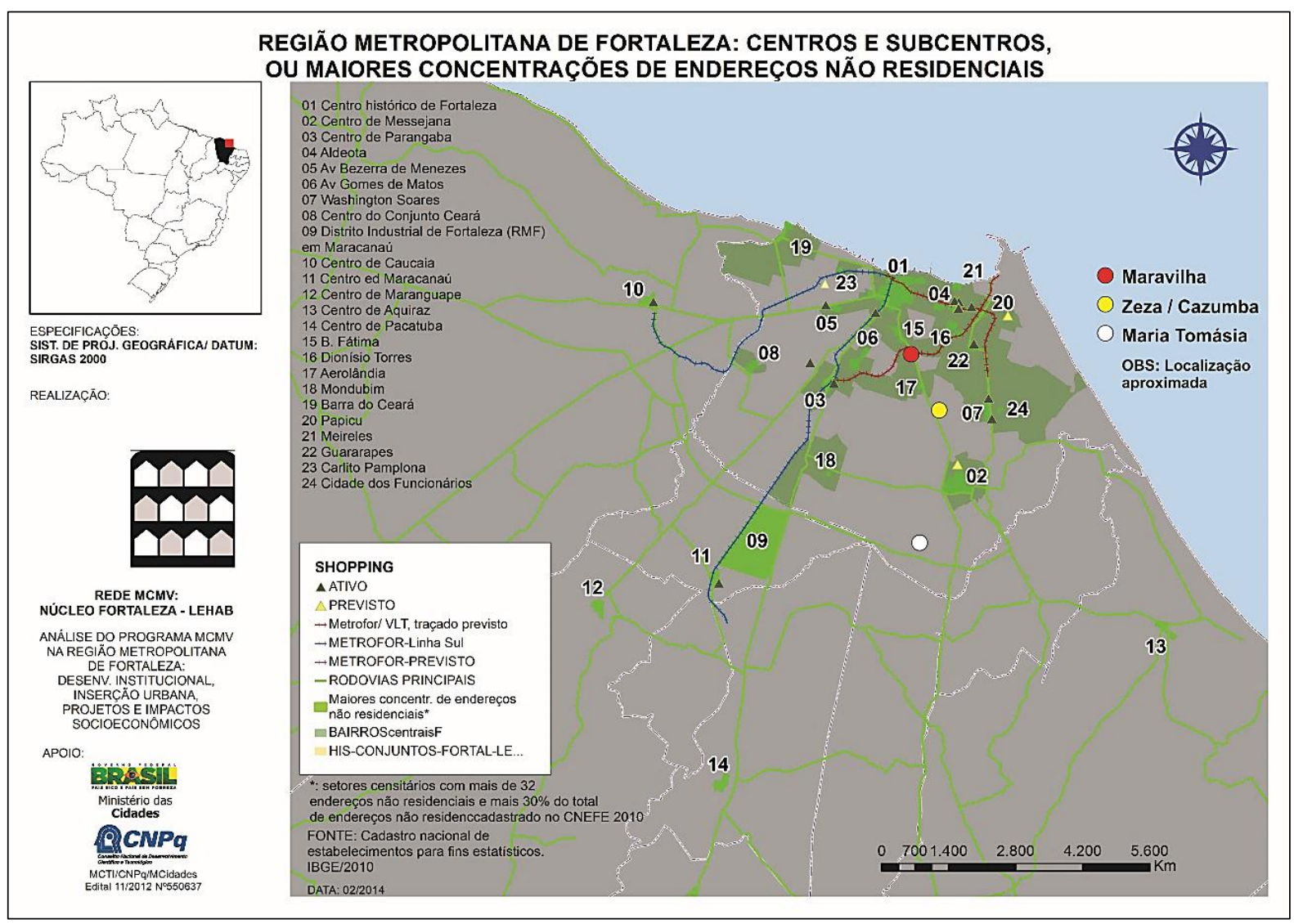

Fonte: LEHAB (2015), adaptação do autor

\subsubsection{Mobilidade}

A metodologia utilizada para a variável Mobilidade, foi adaptada da "Ferramenta de Avaliação de Inserção Urbana para os empreendimentos do programa Minha Casa Minha Vida" desenvolvida pelo LabCidade e pelo IDTP (LABCIDADE e ITDP, 2014). Com esta variável buscamos analisar a relação entre as intervenções e a oferta de transporte público. Para isso, tomamos como indicadores as Opções de Transporte e a Frequência do Transporte.

Para Opções de Transporte, a metodologia consiste em verificar a quantidade de itinerários diferentes que podem ser acessados pelo deslocamento a pé, dentro de uma poligonal distante 500 metros do perímetro do conjunto ${ }^{79}$. Foram considerados itinerários diferentes aqueles que estabelecem uma distância de pelo menos $2 \mathrm{~km}$

\footnotetext{
79 Para o caso da Maravilha, consideramos um perímetro que inclui os Setores I a VI, mas não engloba
} o Setor Planalto Universo. 
entre si ou que conduzem a um terminal de ônibus, já que este proporciona o acesso a uma diversidade de itinerários. A classificação do indicador segue o Quadro 10.

Quadro 10 - Classificação do indicador Opções de Transporte

\begin{tabular}{ll}
\hline CLASSIFICAÇÃO & OPÇÕES DE TRANSPORTE \\
\hline BOM & 4 ou mais itinerários diferentes \\
ACEITÁVEL & Pelo menos 3 itinerários diferentes \\
INSUFICIENTE & 2 ou menos itinerários diferentes \\
\hline
\end{tabular}

Fonte: Elaboração do autor

$\mathrm{Na}$ análise para o conjunto Maria Tomásia, encontramos apenas dois itinerários que podem ser considerados diferentes (Mapa 26). As linhas de ônibus 065 Barroso/Jardim Violeta (Corujão) e 637 - Conjunto Maria Tomásia/Santa Filomena compõem apenas um itinerário, pois não se distanciam $2 \mathrm{~km}$ entre si. Contudo, estas linhas levam ao terminal de ônibus de Messejana, podendo conformar um itinerário distinto, mesmo estando dentro do raio de $2 \mathrm{~km}$ da linha 670 - Sítio São João/Centro/Expresso. Considerando os critérios estabelecidos, atribuímos a classificação “Insuficiente" para o indicador Opções de Transporte, no caso do conjunto Maria Tomásia (Tabela 8).

Na Maravilha, por sua vez, a questão das opções de transporte é diametralmente oposta à do conjunto Maria Tomásia. Nosso estudo concentrou-se apenas nos Setores I a VI, excluindo o Setor Planalto Universo. A análise, no perímetro de 500 metros além da poligonal da intervenção, apontou a oferta de 50 linhas e 29 paradas de ônibus (Mapa 27), enquanto que o conjunto Maria Tomásia apresentou apenas três linhas e uma parada.

Para melhor visualização, optamos por destacar no Mapa 27 apenas 5 itinerários distintos, considerando suas destinações para regiões distintas de Fortaleza, o que nos permite atribuir para a Maravilha a classificação "Bom" no que se refere ao indicador Opções de Transporte, da variável Mobilidade (Tabela 8).

Tabela 8 - Resultado da variável Opções de Transporte, do indicador Mobilidade

\begin{tabular}{llccll}
\hline INTERVENÇÃO & INDICADOR & PARADAS & ITINERARIOS & CLASSIFICAÇÃO & FONTE \\
\hline Maravilha & Opções de Transporte & 29 & $>4$ & BOM & ETUFOR \\
Maria Tomásia & Opções de Transporte & 1 & 2 & INSUFICIENTE & ETUFOR \\
\hline
\end{tabular}


Mapa 26 - Opções de Transporte para o conjunto Maria Tomásia

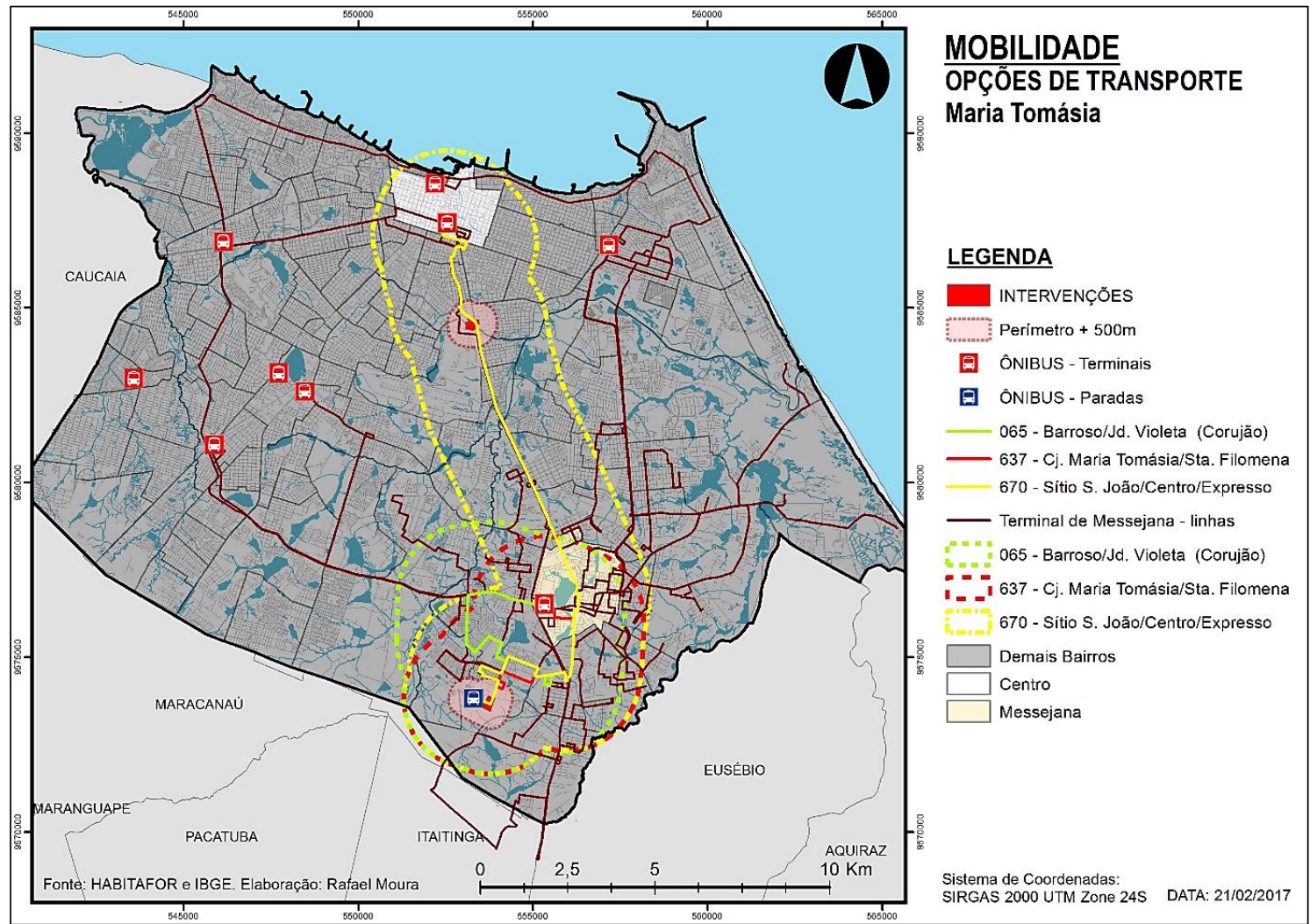

Fonte: ETUFOR, HABITAFOR, elaboração: Rafael Moura

Mapa 27 - Opções de Transporte para os setores I a VI da intervenção Maravilha

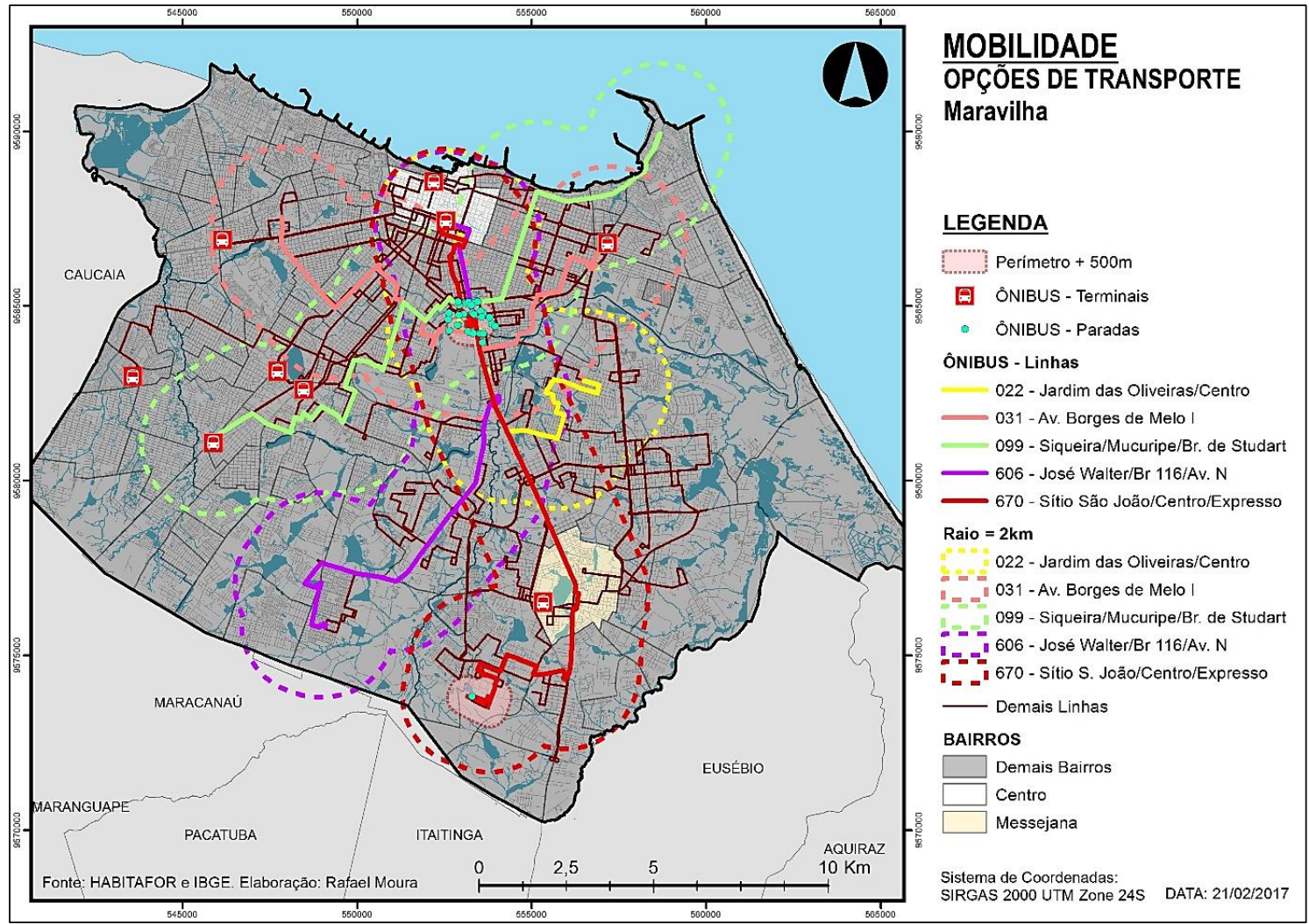

Fonte: ETUFOR, HABITAFOR, elaboração: Rafael Moura 
O indicador Frequência do Transporte avalia, para os itinerários diferentes selecionados nas Opções de Transporte, o intervalo de tempo entre um veículo e outro da mesma linha de transporte e o período de operação da linha durante o dia. Para isso, utilizamo-nos da consulta disponível na página da internet da ETUFOR, na qual é possível verificar ambos os indicadores para cada linha de ônibus ${ }^{80}$.

A análise da Frequência do Transporte foi realizada em duas etapas. Primeiramente, cada itinerário diferente levantado no indicador Opções de Transporte foi qualificado de acordo a frequência das linhas de ônibus que atendem às intervenções em estudo e o período de operação diário de cada linha, conforme a classificação estabelecida no Quadro 11.

Quadro 11 - Análise das opções de transporte levantadas

\begin{tabular}{lll}
\hline CLASSIFICAÇÃO & FREQUÊNCIA DA LINHA & PERÍODO DE OPERAÇÃO \\
\hline BOM & Até 10 minutos & 24 horas \\
ACEITÁVEL & 11 a 20 minutos & 17 horas ou mais \\
INSUFICIENTE & Acima de 20 minutos & Menos de 17 horas \\
\hline
\end{tabular}

Fonte: Elaboração do autor

Para a intervenção Maravilha, analisamos os itinerários destacados no Mapa 27, porém substituímos a linha 670 - Sítio São João/Centro/Expresso, já incluída na análise para o conjunto Maria Tomásia, pela linha 011 - Circular I, que constitui um outro itinerário distinto. O resultado da análise pode ser visto na Tabela 9.

Tabela 9 - Resultado da análise dos itinerários

\begin{tabular}{lclll}
\hline CONJUNTO & ITINERÁRIO & $\begin{array}{l}\text { FREQUÊNCIA } \\
\text { DA LINHA }\end{array}$ & $\begin{array}{l}\text { PERIÓDO DE } \\
\text { OPERAÇÃO }\end{array}$ & CLASSIFICAÇÃO \\
\hline Maria & 65 & A cada $50 \mathrm{~min}$ & $3 \mathrm{~h} 52 \mathrm{~min}$ & INSUFICIENTE \\
Tomásia & 637 & A cada $27 \mathrm{~min}$ & $19 \mathrm{~h}$ & INSUFICIENTE \\
& 670 & A cada $20 \mathrm{~min}$ & $16 \mathrm{~h} 22 \mathrm{~min}$ & INSUFICIENTE \\
\hline \multirow{3}{*}{ Maravilha } & 11 & A cada $9 \mathrm{~min}$ & $18 \mathrm{~h} 22 \mathrm{~min}$ & ACEITÁVEL \\
& 22 & A cada $24 \mathrm{~min}$ & $18 \mathrm{~h} 34 \mathrm{~min}$ & INSUFICIENTE \\
& 31 & A cada $13 \mathrm{~min}$ & $18 \mathrm{~h} 46 \mathrm{~min}$ & ACEITÁVEL \\
& 99 & A cada $11 \mathrm{~min}$ & $18 \mathrm{~h} 50 \mathrm{~min}$ & ACEITÁVEL \\
& 606 & A cada $22 \mathrm{~min}$ & $17 \mathrm{~h} 40 \mathrm{~min}$ & INSUFICIENTE \\
\hline
\end{tabular}

Fonte: ETUFOR, elaboração

80 Os dados quanto ao intervalo de tempo e período de operação das linhas de ônibus em Fortaleza estão disponíveis em <http://www.etufor.ce.gov.br/GIST/linHorarios.htm>, acessado em 21/02/2017. 
Concluída a análise dos itinerários, passamos à etapa de análise do indicador da Frequência do Transporte. Para o caso de a frequência da linha e o período de operação apresentarem qualificações distintas para um mesmo itinerário, consideramos o resultado inferior. A classificação seguiu o Quadro 12.

Quadro 12 - Classificação do indicador Frequência do Transporte

\begin{tabular}{ll}
\hline CLASSIFICAÇÃO & FREQUÊNCIA DO TRANSPORTE \\
\hline BOM & Pelo menos 3 opções de itinerário com frequência Boa \\
ACEITÁVEL & Pelo menos 3 opções de itinerário com frequência Aceitável \\
INSUFICIENTE & Apenas 3 opções de itinerário e um destes classificado como Insuficiente \\
\hline
\end{tabular}

Fonte: Elaboração do autor

Para o conjunto Maria Tomásia, a análise demonstrou a existência de apenas 2 itinerários considerados distintos, o que já nos permite atribuir a classificação "Insuficiente", segundo o indicador Frequência do Transporte. No caso da Maravilha, este indicador foi classificado como "Aceitável", devido à existência de pelo menos três opções de itinerário classificadas como aceitável (Quadro 13).

Quadro 13 - Resultados para o indicador Frequência do Transporte

\begin{tabular}{llll}
\hline CONJUNTO & VARIAVEL & INDICADOR & CLASSIFICAÇÃO FINAL \\
\hline Maria Tomásia & Mobilidade & Frequência do Transporte & INSUFICENTE \\
\hline Maravilha & Mobilidade & Frequência do Transporte & ACEITÁVEL \\
\hline
\end{tabular}

Fonte: elaboração do autor

\subsubsection{Infraestrutura}

Para a análise da infraestrutura buscamos apoio nos dados do Instituto Brasileiro de Geografia e Estatística (IBGE). Foram definidos quatro indicadores: abastecimento de água; esgotamento sanitário; destino do lixo; e energia elétrica. Através de dados levantados no Censo 2010, verificamos a situação de atendimento da infraestrutura nos setores censitários que englobam os conjuntos Maravilha e Maria Tomásia, com setores que constituem o entorno próximo, em uma distância aproximada de um quilômetro do perímetro do conjunto (Mapa 28 e Mapa 29). 
Mapa 28 - Setores censitários e área de entorno de $1 \mathrm{~km}$ a partir do perímetro na Maravilha

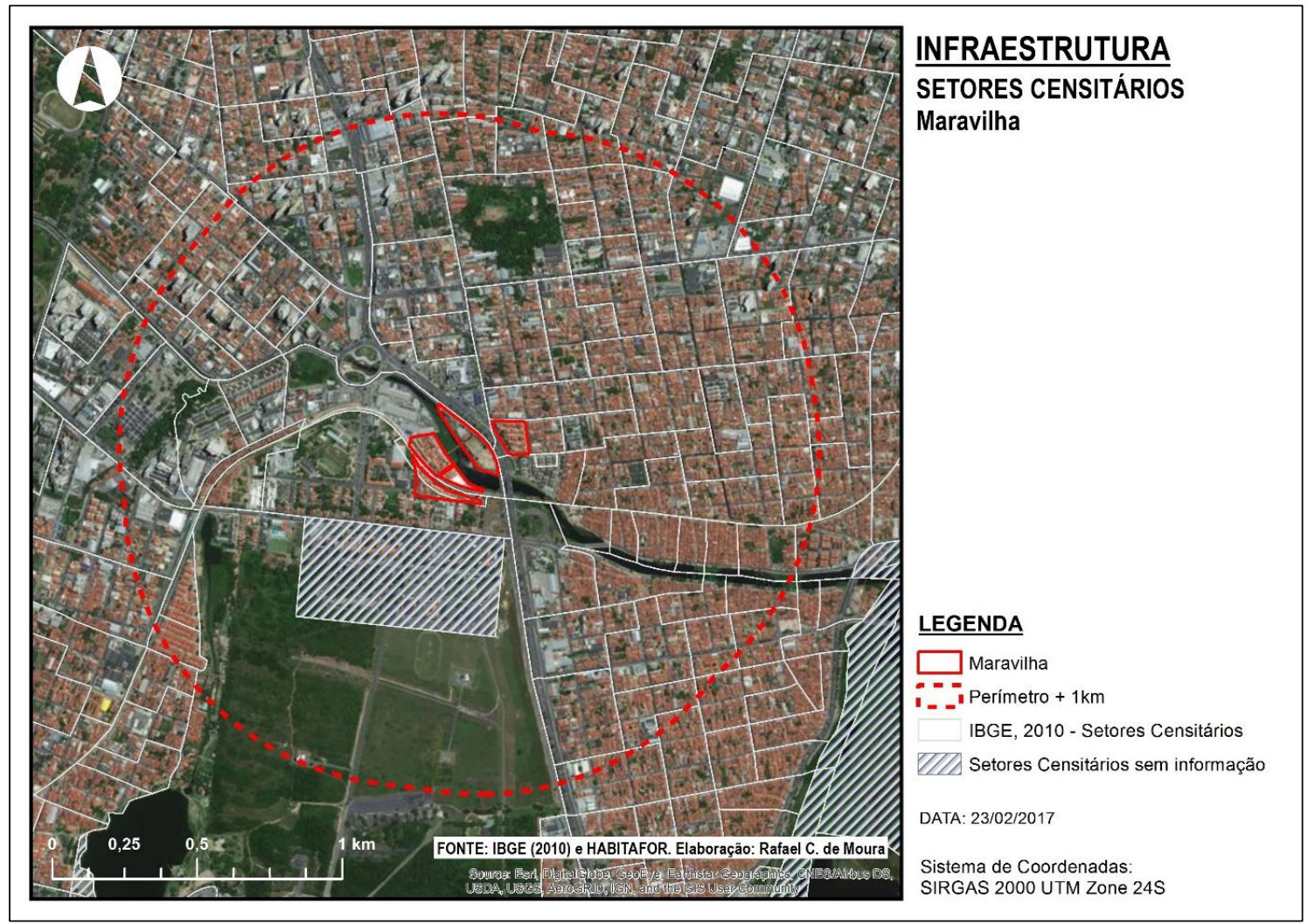

Fonte: IBGE (2010), ArcGIS e HABITAFOR, elaboração do autor

Mapa 29 - Setores censitários e área de entorno de $1 \mathrm{~km}$ a partir do perímetro no Maria Tomásia

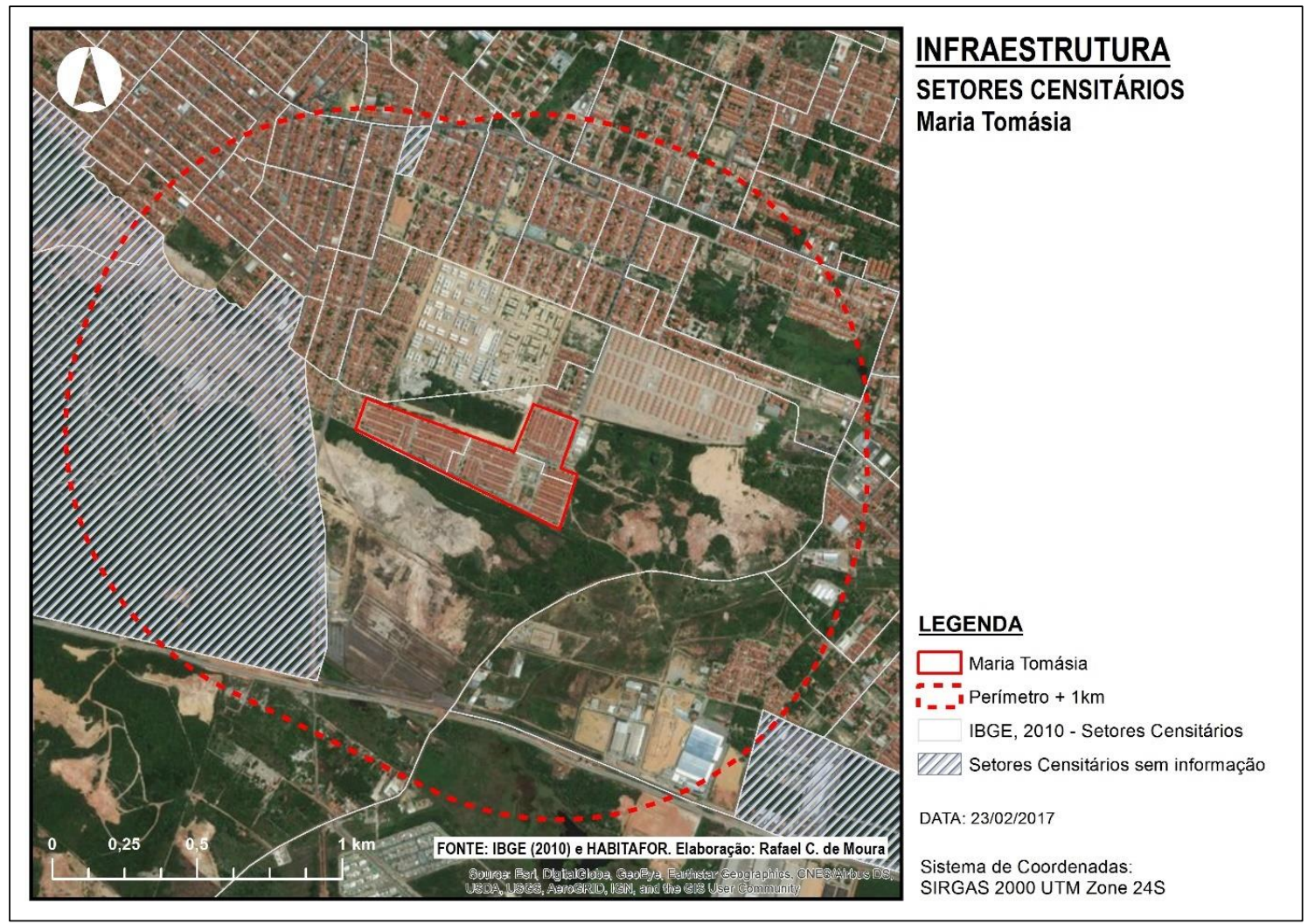

Fonte: IBGE (2010), ArcGIS e HABITAFOR, elaboração do autor 


\subsection{3.a. Abastecimento de Água}

Para a análise do Abastecimento de Água nos casos selecionados, utilizamo-nos da variável "V012 - Domicílios particulares permanentes com abastecimento de água da rede geral" que consta na tabela Domicilios01, dos resultados do universo, e está disponível para consulta na página da internet do IBGE ${ }^{81}$.

De posse dos dados, procedemos a sua espacialização no território por meio de software de Sistemas de Informação Geográfica (SIG), através da classificação de quebras naturais. Observamos que ambas as intervenções se localizam em áreas de maior percentual de domicílios permanentes com o abastecimento de água realizado através de ligação à rede geral (Mapa 30). Não se percebe grande variação entre a área dos conjuntos e do entorno.

Mapa 30 - Análise do abastecimento de água na Maravilha e no Maria Tomásia e entorno

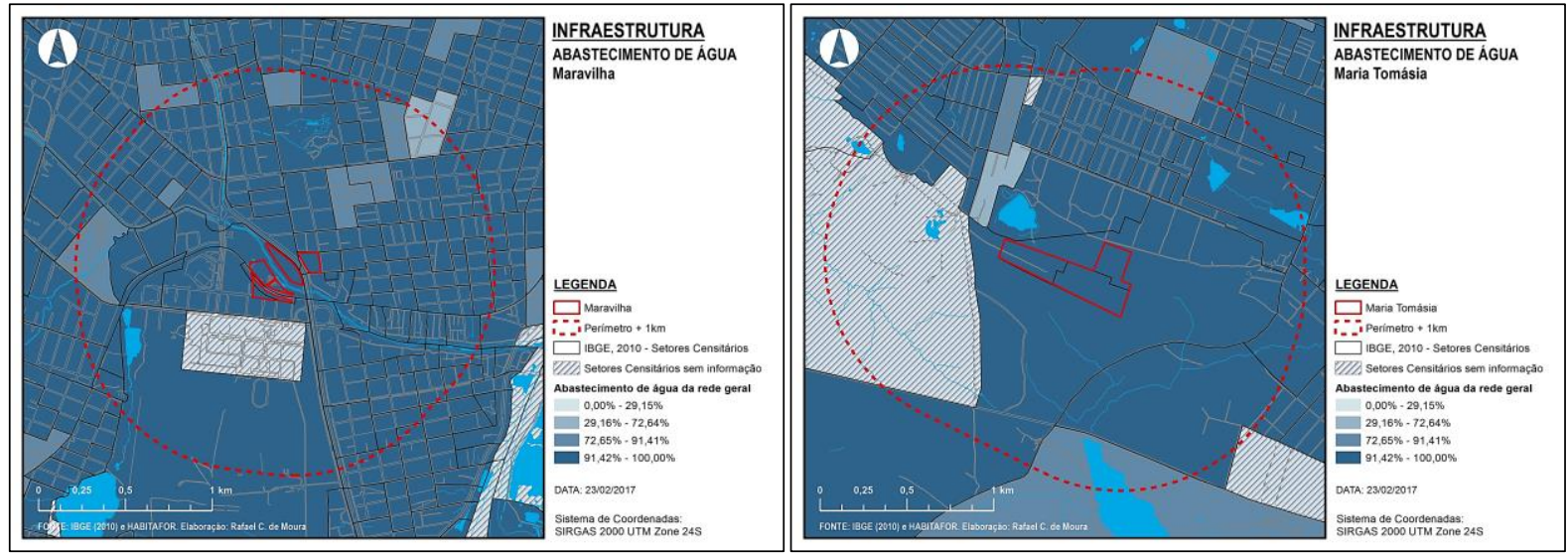

Fonte: IBGE (2010) e Habitafor, elaboração do autor

\subsection{3.b. Esgotamento Sanitário}

Para a análise do Esgotamento Sanitário, fizemos uso da variável "V017 - Domicílios particulares permanentes com banheiro de uso exclusivo dos moradores ou sanitário e esgotamento sanitário via rede geral de esgoto ou pluvial" que consta na tabela Domicilios 01 , dos resultados do universo. $O$ fato de serem consideradas as ligações à rede de drenagem pluvial acaba por ocultar um pouco a realidade, aumentando o

${ }^{81}$ Disponível em: <http://downloads.ibge.gov.br/downloads_estatisticas.htm>. Acesso em: 23/08/2015. 
percentual de domicílios com ligação à rede, muito embora a rede pluvial não seja o destino adequado para o esgoto.

Realizamos a espacialização dos dados no território por meio de software de SIG, novamente através do método de quebras naturais. Observamos diferenças entre as áreas de entorno de cada intervenção. $\mathrm{Na}$ área onde a Maravilha está inserida, o percentual de domicílios com esgotamento via rede de esgoto ou pluvial alcança a faixa entre $84,68 \%$ e 100\% (Mapa 31). Em áreas de assentamentos precários, como Lagamar e Raul Barbosa, verificamos a redução desse percentual (manchas mais claras à direita do Mapa 31).

Mapa 31 - Análise do esgotamento sanitário na Maravilha e entorno

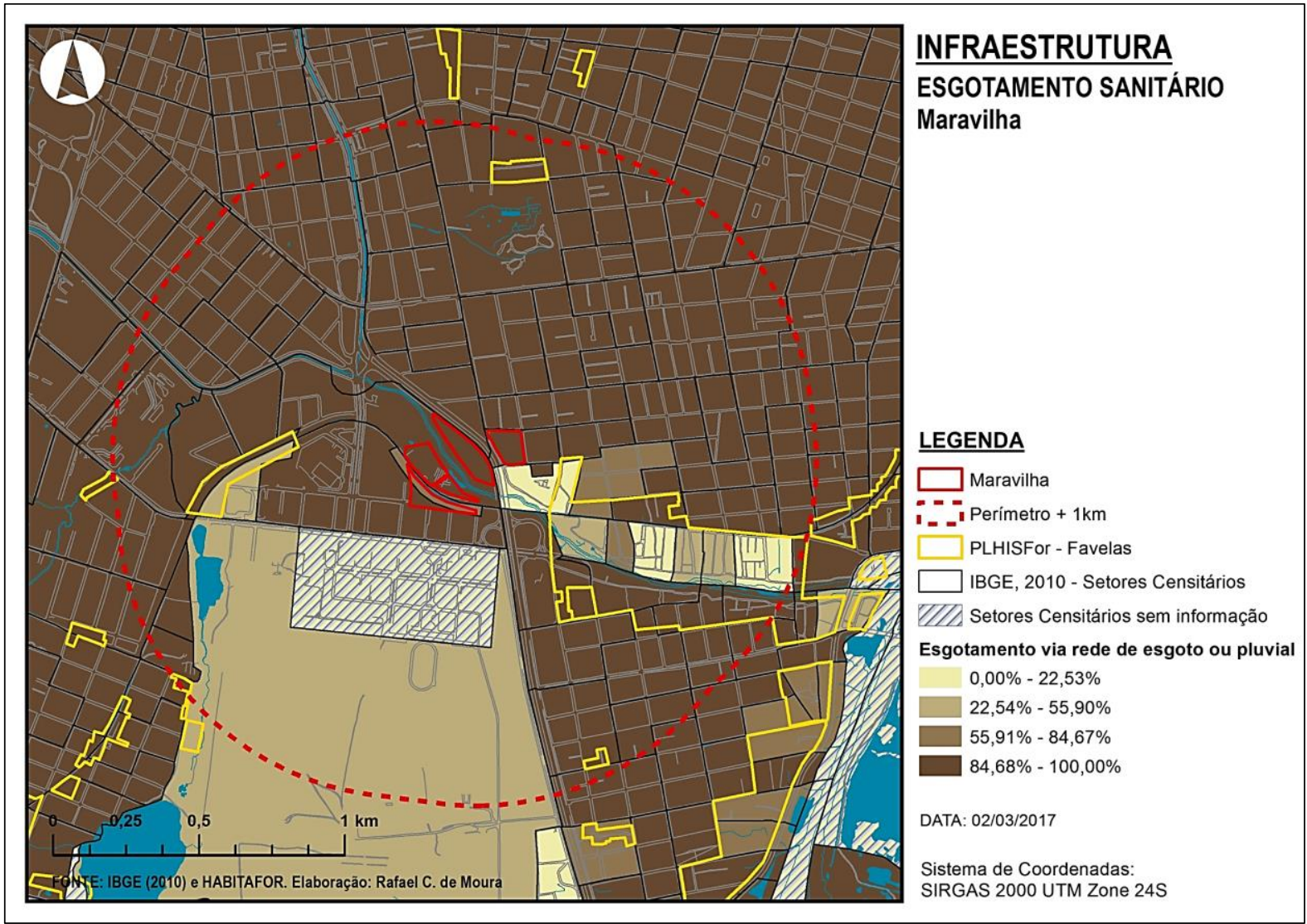

Fonte: IBGE (2010) e HABITAFOR, elaboração do autor

No caso do entorno do conjunto Maria Tomásia, observamos uma maior área com baixo percentual de domicílios com esgotamento via rede de esgoto ou pluvial em razão da inexistência de tal rede (Mapa 32).

Os conjuntos habitacionais implementados pelo poder público, em geral, possuem estação de tratamento de esgoto para solucionar essa questão. Contudo, cabe 
destacar que a precária manutenção destes equipamentos tem resultado em problemas, como evidenciado no próprio Maria Tomásia (TRIBUNA DO CEARÁ, 2014). A recente produção intensa de conjuntos habitacionais para a população de baixa renda, através do PMCMV, em áreas próximas ao Maria Tomásia traz a perspectiva de uma solução em definitivo para a questão do esgotamento sanitário na região, ao menos conforme técnicos da HABITAFOR (AQUINO, PAIVA e BRAGA, 2016).

Mapa 32 - Análise do esgotamento sanitário no Maria Tomásia e entorno

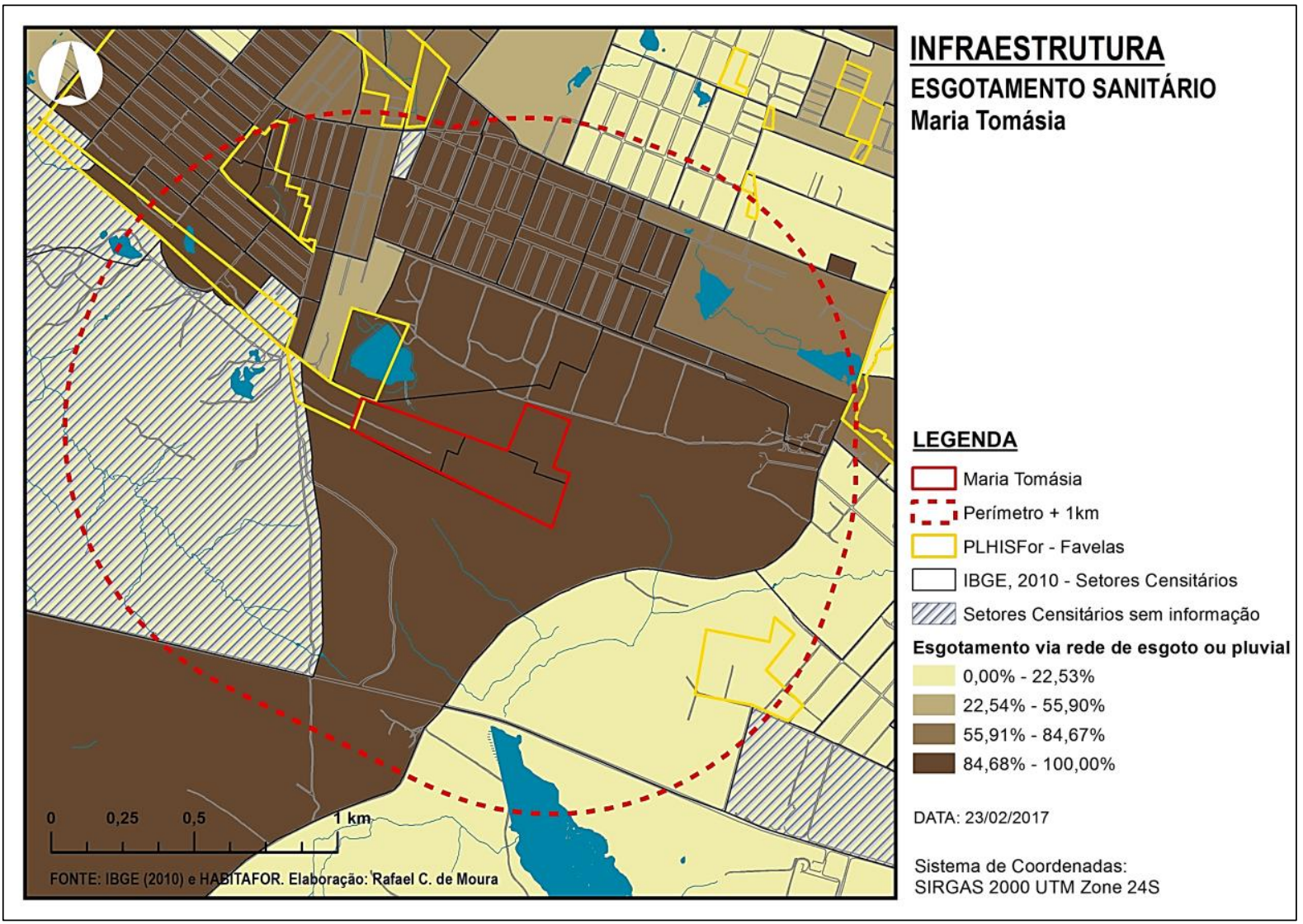

Fonte: IBGE (2010) e HABITAFOR, elaboração do autor

\subsection{3.c. Destino do Lixo}

Na análise da destinação do lixo na Maravilha e no Maria Tomásia, foi utilizada a variável "V036 - Domicílios particulares permanentes com lixo coletado por serviço de limpeza”, também na tabela Domicilios01. A espacialização dos dados do Censo por 
meio de SIG, através da classificação por quebras naturais, aponta para uma boa difusão do serviço de coleta de lixo nas duas áreas em estudo ${ }^{82}$.

Os setores censitários que abrangem a intervenção na Maravilha apontam um percentual de domicílios com coleta de lixo por serviço público acima de 88\% (Mapa 33). Para seu entorno, podemos reiterar a observação realizada no indicador de esgotamento sanitário, pois há uma redução do percentual em áreas de assentamento precário, como no Lagamar (manchas mais claras à direita do Mapa 33).

Mapa 33 - Análise do destino do lixo na Maravilha e entorno

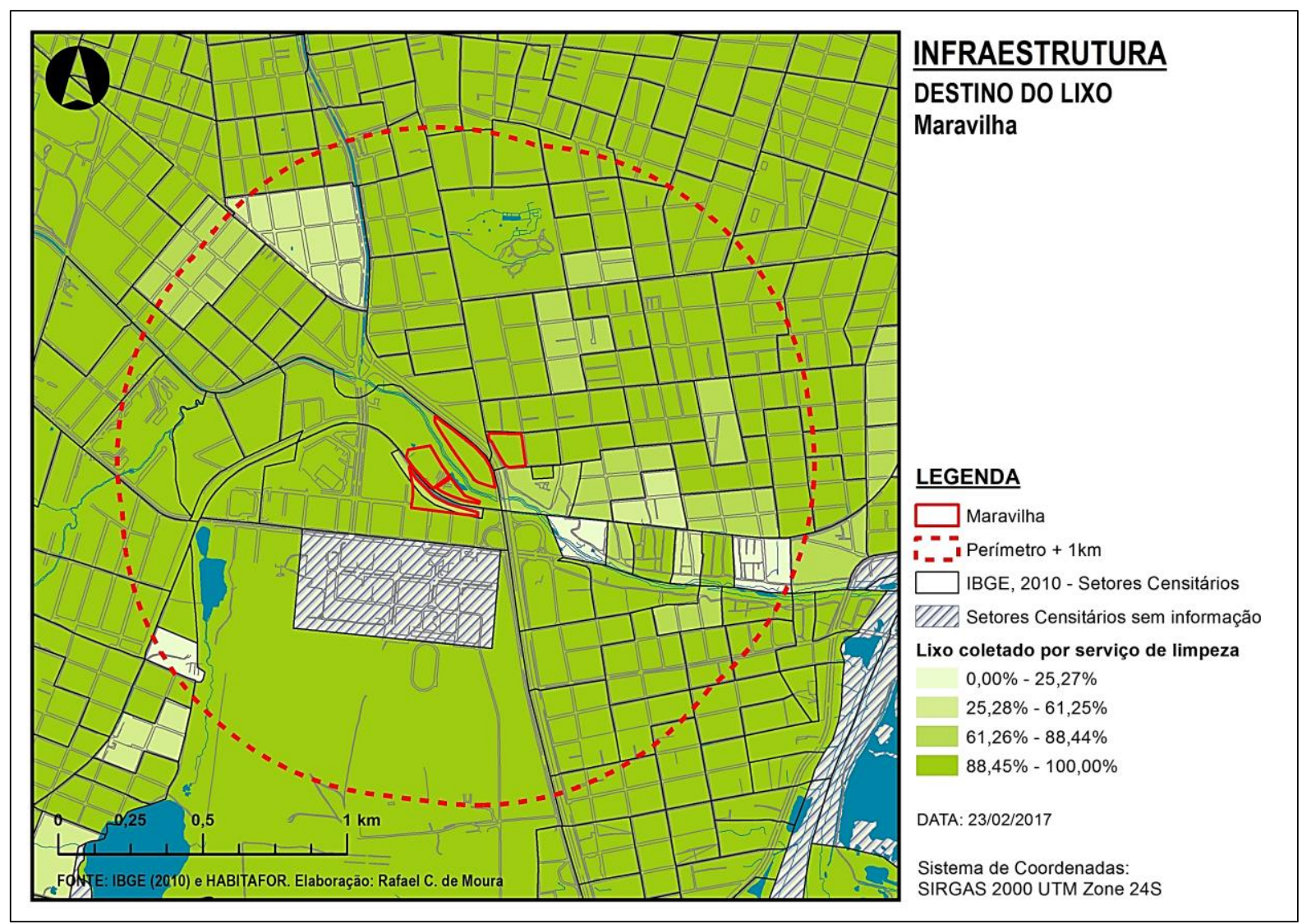

Fonte: IBGE (2010) e Habitafor, elaboração do autor

Mesmo para o conjunto Maria Tomásia, com sua localização periférica em Fortaleza, o censo 2010 apontou um percentual de domicílios atendidos pelo serviço de limpeza acima de $88 \%$. Já em seu entorno, alguns setores censitários demonstram uma redução nesse percentual (Mapa 34).

$82 \mathrm{O}$ dado disponibilizado pelo IBGE apenas aponta a existência da coleta de lixo, mas não aponta a qualidade dessa coleta, como a frequência em que é realizada, se é diária, ou semanal, ou mensal. 
Mapa 34 - Análise do destino do lixo no Maria Tomásia e entorno

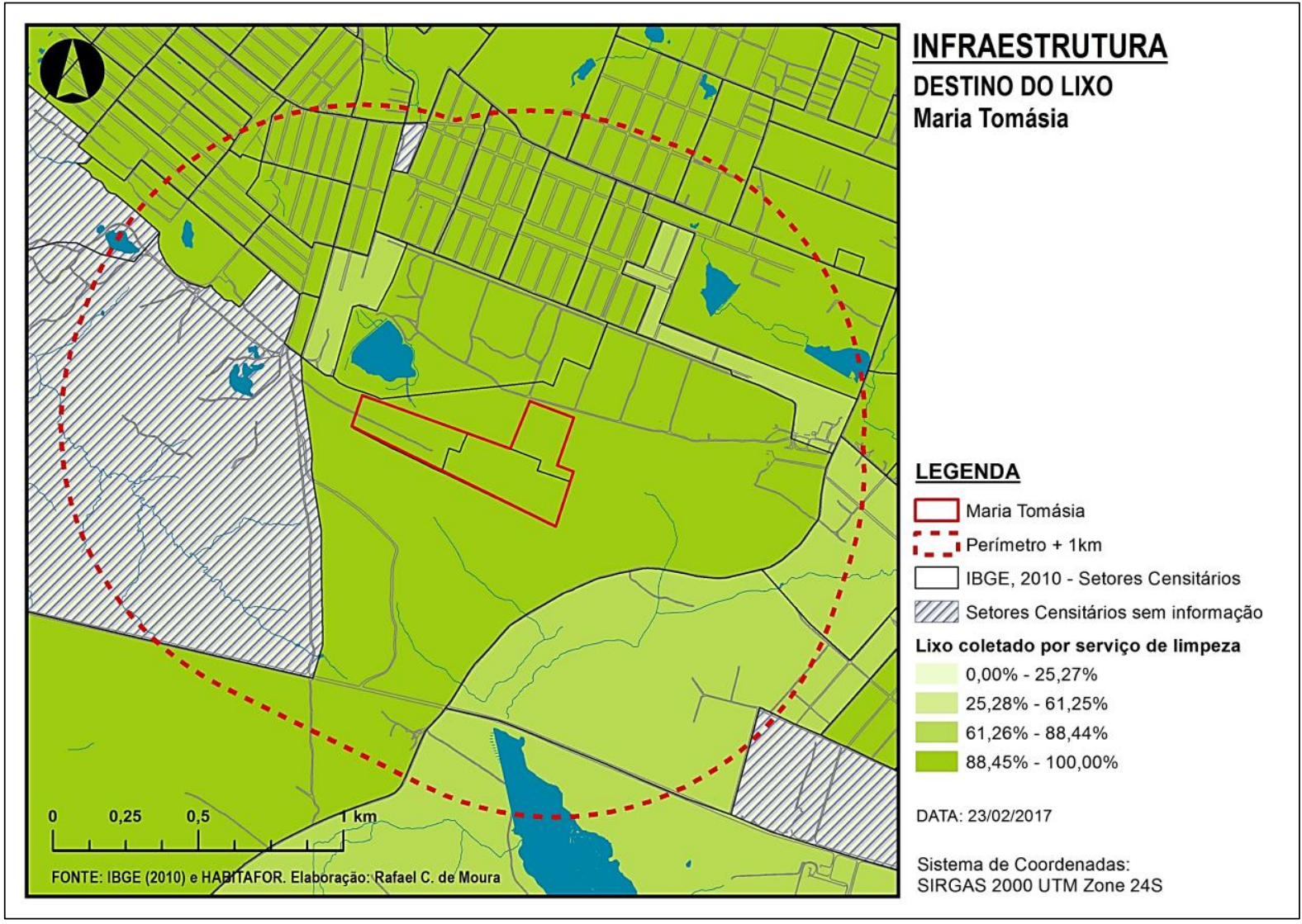

Fonte: IBGE (2010) e Habitafor. Elaboração: Rafael Moura.

\subsection{3.d. Energia Elétrica}

Para a análise das ligações à rede de energia elétrica, foi utilizada a variável "V044 Domicílios particulares permanentes com energia elétrica de companhia distribuidora", que pode ser consultada na tabela Domicilios01, do Censo 2010, seguindo o mesmo procedimento de espacialização dos dados com software de SIG.

Tanto para a Maravilha, quanto para o Maria Tomásia, a análise dos dados censitários aponta um percentual de domicílios com energia elétrica de companhia distribuidora acima de $95 \%$, assim como para a área que delimitamos como entorno, $1 \mathrm{~km}$ após o perímetro das intervenções (Mapa 35). É possível perceber a ampla difusão do serviço de energia elétrica. 
Mapa 35 - Análise do serviço de energia elétrica na Maravilha e no Maria Tomásia
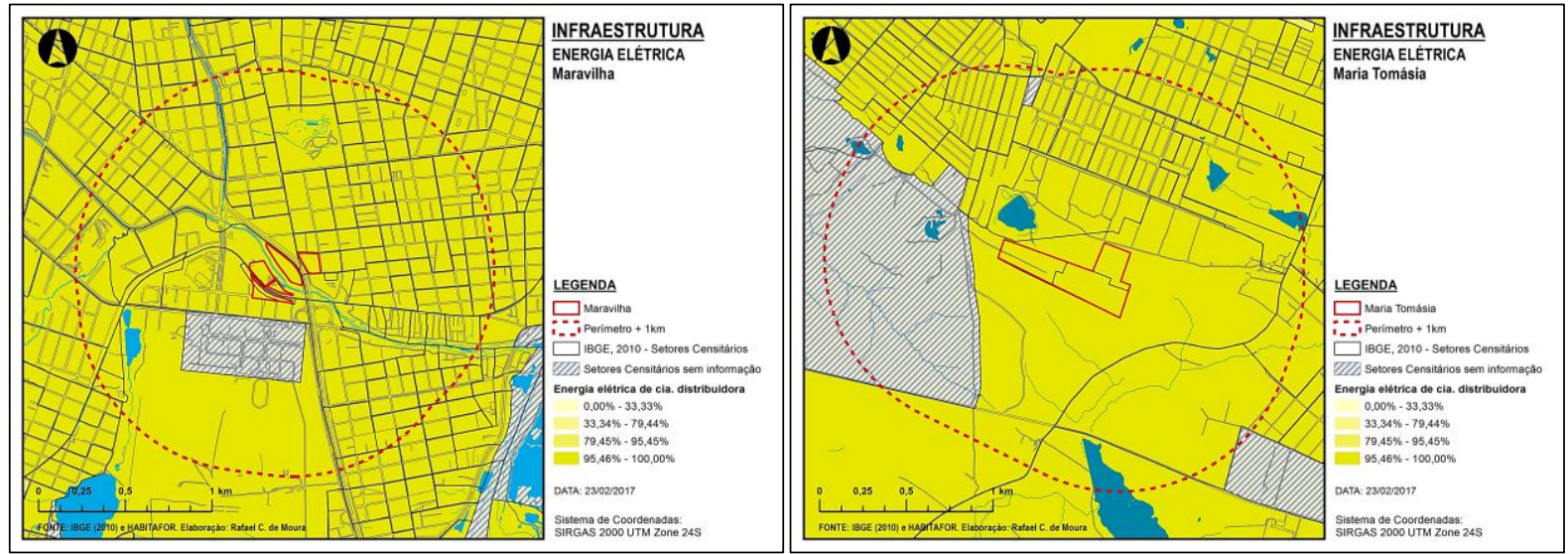

Fonte: IBGE (2010) e HABITAFOR, elaboração do autor

\subsubsection{Serviços Urbanos}

A variável Serviços Urbanos tem como objetivo avaliar a oferta de equipamentos públicos para os moradores da Maravilha e do Maria Tomásia. Para isso, utilizamos três indicadores de uso em função do raio de abrangência e da frequência de uso dos equipamentos: "Usos cotidianos ou de abrangência local", "Usos eventuais ou de abrangência do bairro" e "Usos esporádicos ou de abrangência da cidade". Tais indicadores foram estabelecidos com base na ferramenta de avaliação da inserção urbana desenvolvida pelo LabCidade da FAUUSP (LABCIDADE e ITDP, 2014). A seguir detalharemos a análise para cada indicador.

Sabemos que para uma análise mais profunda das características de inserção urbana das intervenções, com relação aos equipamentos públicos, seria necessário verificar a capacidade de suporte de cada equipamento em relação à demanda da área onde estão inseridos os estudos de caso, assim como realizar uma caracterização das condições de manutenção das edificações e espaços públicos. Contundo, pelas limitações do trabalho, restringimo-nos apenas à verificação da existência ou não dos equipamentos. 


\subsection{4.a. Usos cotidianos ou de abrangência local}

O indicador "Usos cotidianos ou de abrangência local" objetiva levantar a existência de equipamentos que necessitem manter uma proximidade com o uso residencial, pois envolvem deslocamentos diários, por vezes em caminhadas com crianças e que, portanto, possuem abrangência mais restrita a localidades e vizinhanças. Nesta classificação se enquadram equipamentos como: creches públicas, escolas públicas de ensino infantil, escolas públicas de ensino fundamental I e áreas livres para lazer.

A ferramenta de análise do LabCidade recomenda como parâmetro de análise a distância de deslocamento de 15 minutos a pé, ou o equivalente a 1000 metros de percurso (LABCIDADE e ITDP, 2014). Por sua vez, Daros (2007) recomenda 500 metros como parâmetro adequado para a distância a ser percorrida a pé. Para facilitar o uso da ferramenta, adotamos um raio de 500 metros a partir do perímetro do conjunto, que orientou os parâmetros de classificação (Quadro 14).

Quadro 14 - Classificação para o indicador "Usos cotidianos ou de abrangência local"

\begin{tabular}{ll}
\hline CLASSIFICAÇÃO & PARÂMETRO \\
\hline BOM & Foram encontrados todos os usos no raio de 500 metros a partir do perímetro \\
ACEITÁVEL & Pelo menos um dos usos está fora do raio de 500 metros a partir do perímetro \\
INSUFICIENTE & Pelo menos um dos usos estabelecidos não é ofertado \\
\hline
\end{tabular}

Fonte: elaboração do autor

Para a Maravilha, foi encontrado pelo menos um equipamento de cada tipo, dentro da distância estabelecida que the confere a classificação "Bom" (Mapa 36). Contudo, lembramos que o acesso aos equipamentos de esporte e lazer que foram implantados no Setor IV é dificultado pela necessidade de atravessar as barreiras constituídas pelo canal do riacho Tauape, pela rodovia BR-116 e pelo ramal ferroviário. No Maria Tomásia não foi constatado equipamento de ensino infantil, o que the confere a classificação, "Insuficiente” (Mapa 37).

Quando comparamos os dois estudos de caso, percebemos uma maior oferta de áreas livres de lazer e de escolas de ensino fundamental I, além de uma maior proximidade dos equipamentos à intervenção, na Maravilha. No Maria Tomásia, as escolas de ensino fundamental I se localizam no limite do raio de $500 \mathrm{~m}$, ou um pouco depois dele. Também lembramos que duas áreas de lazer previstas no projeto, nos extremos do conjunto, não foram implementadas. 
Mapa 36 - Usos cotidianos ou de abrangência local na Maravilha

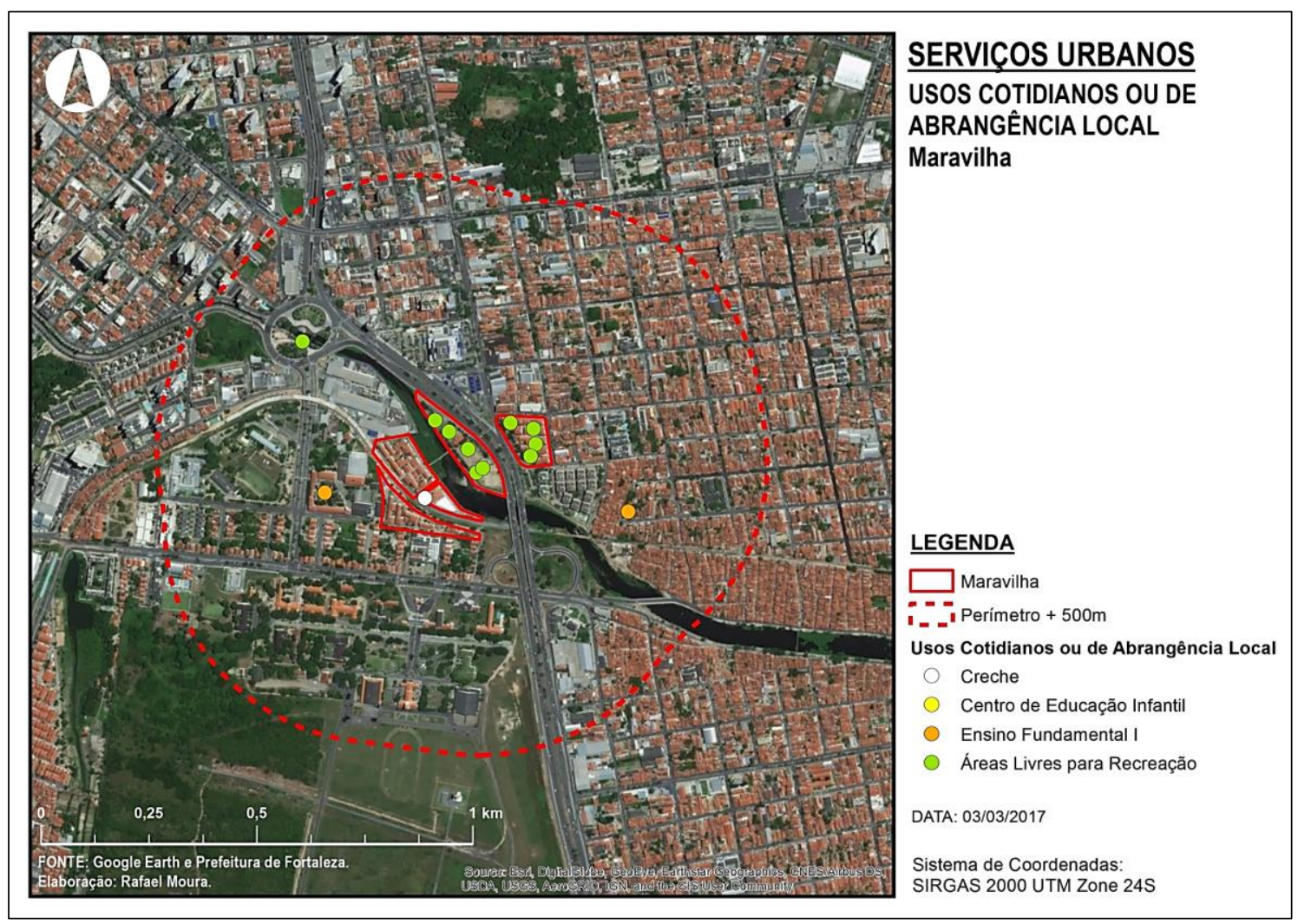

Fonte: Google Earth, HABITAFOR, elaboração do autor

Mapa 37 - Usos cotidianos ou de abrangência local no Maria Tomásia

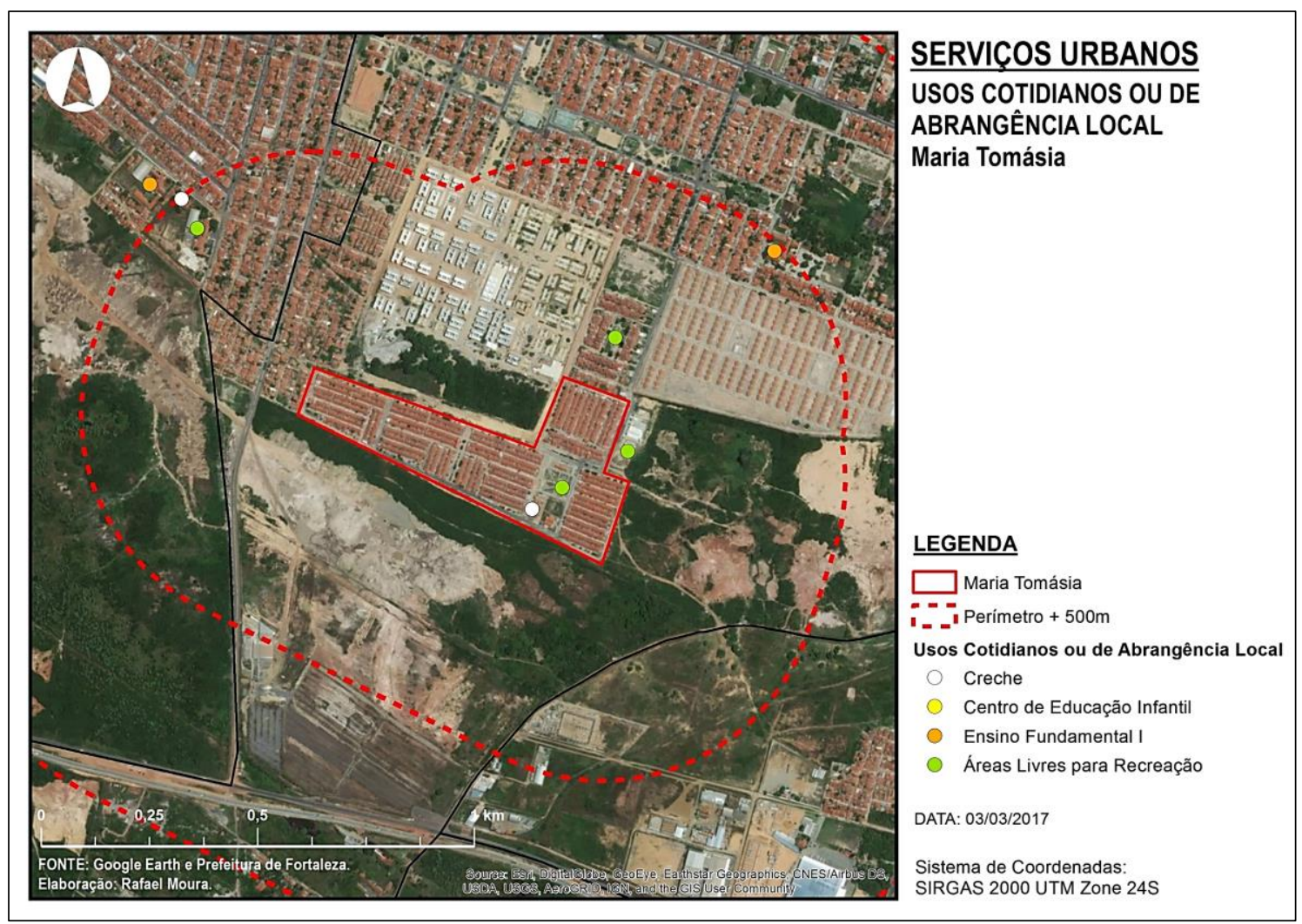

Fonte: Google Earth, HABITAFOR, elaboração do autor 


\subsection{4.b. Usos Eventuais ou de Abrangência do Bairro}

O indicador "Usos Eventuais ou de Abrangência do Bairro" tem como objetivo levantar a oferta de equipamentos que podem estar localizados a uma distância um pouco maior em relação às habitações, pois seus usuários são jovens ou adultos, com maior autonomia para deslocamento. Consideramos de uso eventual equipamentos como: escolas públicas de ensino fundamental II, escolas públicas de ensino médio ou de ensino profissionalizante, unidades de saúde com pronto atendimento (como postos de saúde) e equipamentos para assistência social (como os Conselhos Tutelares e os Centros de Referência em Assistência Social - CRAS).

A ferramenta do LabCidade estabelece como parâmetro de análise a distância de um percurso de 1400 metros realizados a pé (LABCIDADE e ITDP, 2014). Neste trabalho, como forma de simplificar a verificação, utilizamos um raio de um quilômetro a partir do perímetro do conjunto, desconsiderando o percurso, que guiou a definição da classificação (Quadro 15).

Quadro 15 - Classificação para o indicador "Usos Eventuais ou de Abrangência do Bairro"

\begin{tabular}{ll}
\hline CLASSIFICAÇÃO & PARÂMETRO \\
\hline BOM & Foram encontrados todos os usos no raio de $1 \mathrm{~km}$ a partir do perímetro \\
ACEITÁVEL & Pelo menos um dos usos estava fora do raio de $1 \mathrm{~km}$ a partir do perímetro \\
INSUFICIENTE & Pelo menos um dos usos estabelecidos não é ofertado \\
\hline
\end{tabular}

Fonte: elaboração do autor

Para o indicador "Usos Eventuais ou de Abrangência do Bairro", os dois estudos de caso, Maravilha e Maria Tomásia, apresentaram pelo menos um equipamento de cada tipo definido como de uso eventual ou de abrangência do bairro (Mapa 38 e Mapa 39). A classificação de ambos foi "Bom".

$\mathrm{Na}$ Maravilha, as barreiras ao deslocamento (canal, rodovia e ferrovia), dificultam o acesso ao equipamento voltado para assistência social, localizado próximo ao limite do raio de $1 \mathrm{~km}$ a partir do perímetro da intervenção, que estabelecemos como parâmetro de análise (Mapa 38). Já no Maria Tomásia, são as escolas, tanto de ensino fundamental II, como de ensino médio ou profissionalizante, que mantém maior distância em relação ao conjunto (Mapa 39). 
Habitação social em Fortaleza (CE) pós Ministério das Cidades / Capítulo 03 - Página | 154

Mapa 38 - Usos eventuais ou de abrangência do bairro na Maravilha

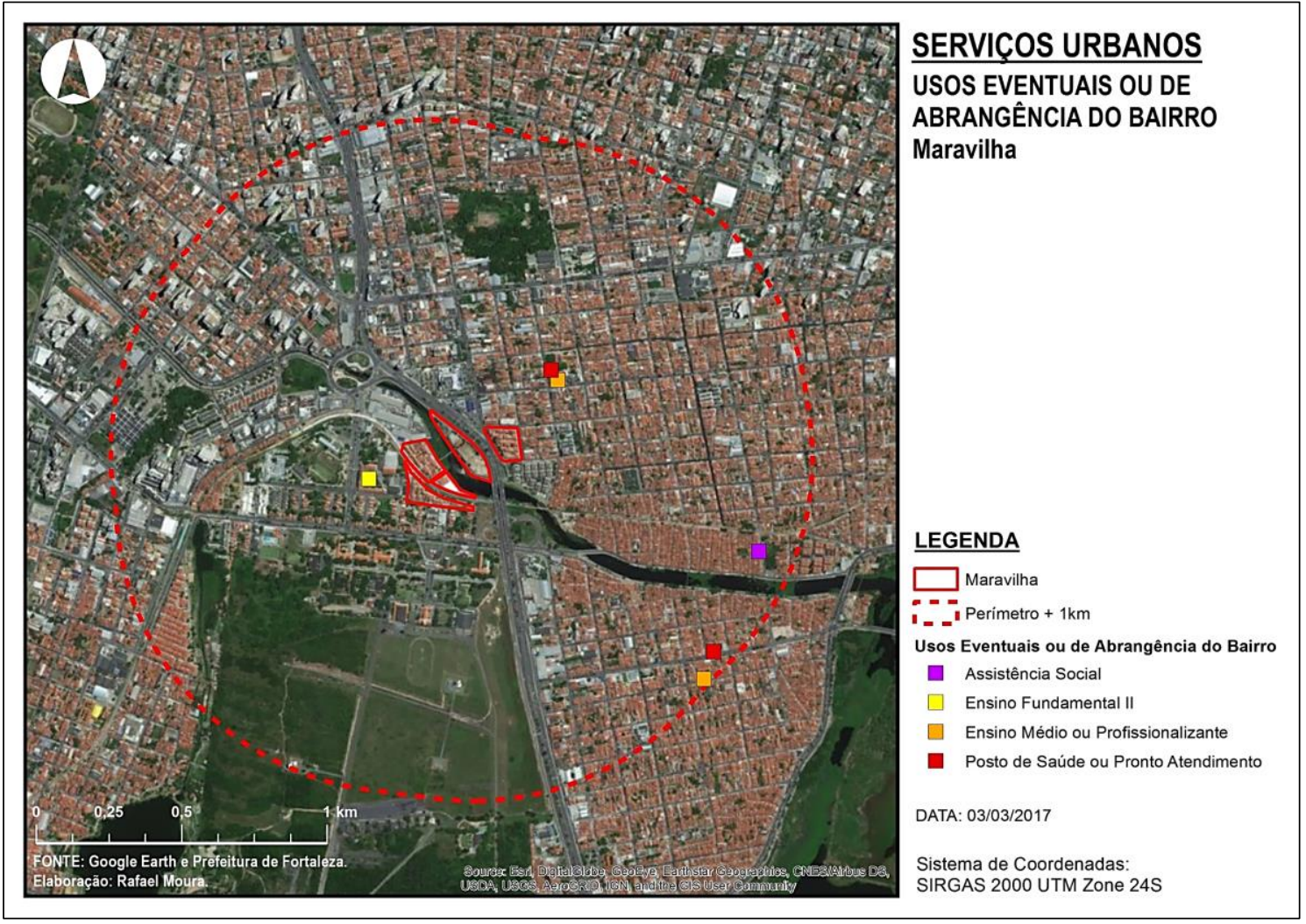

Fonte: Google Earth, HABITAFOR, elaboração do autor

Mapa 39 - Usos eventuais ou de abrangência do bairro no Maria Tomásia

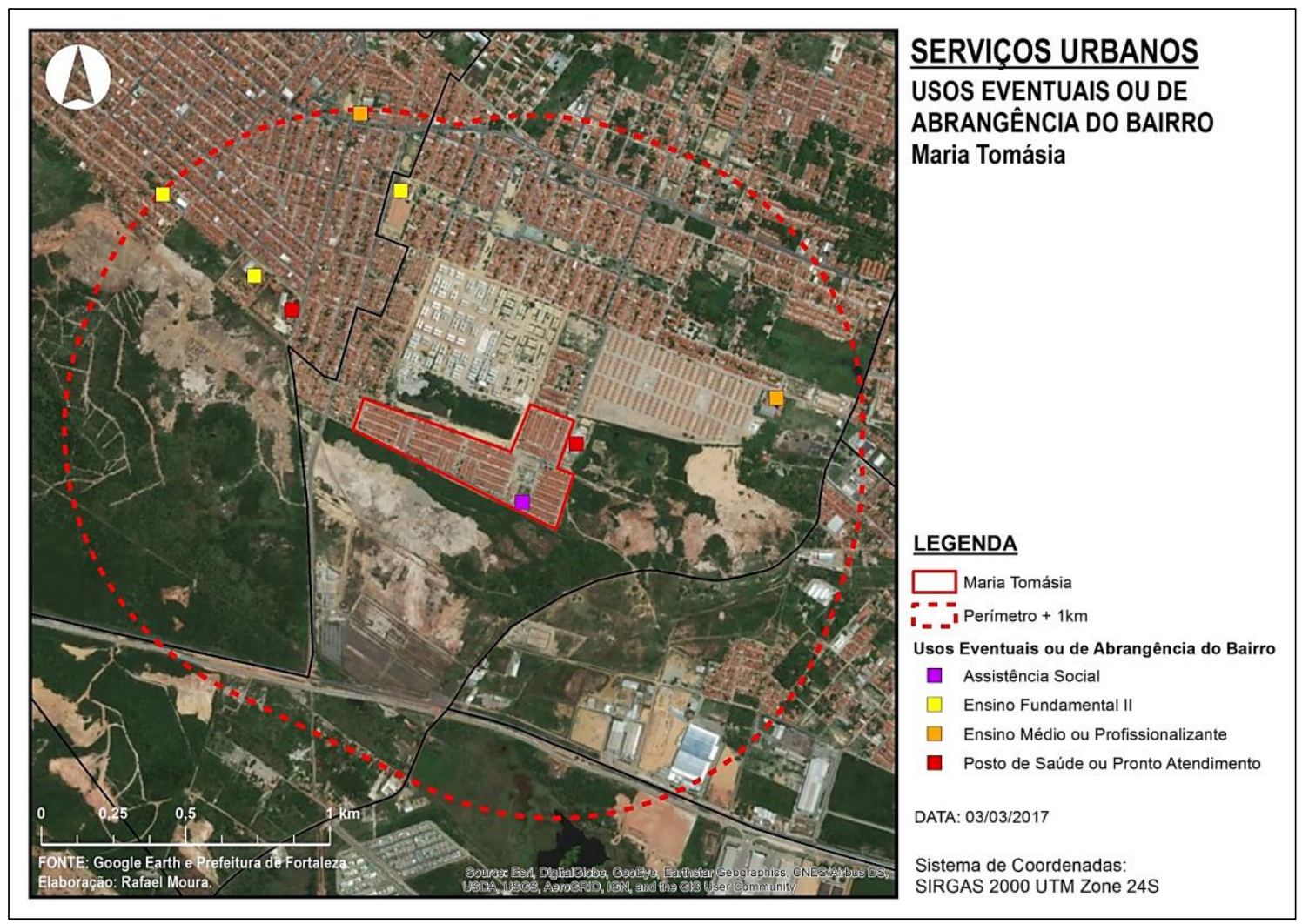

Fonte: Google Earth, HABITAFOR, elaboração do autor 


\subsection{4.c. Usos Esporádicos ou de Abrangência da Cidade}

O indicador "Usos Esporádicos ou de Abrangência da Cidade" tem como objetivo levantar a oferta de equipamentos que cuja utilização tenha baixa frequência no cotidiano dos moradores, mas um raio de influência relacionado à escala da cidade, devido a sua importância. Consideramos de uso esporádico os equipamentos: hospital público, instituições públicas de ensino superior, centro público administrativo (como agências do INSS, Secretarias Regionais, escolas públicas de ensino médio, unidades de saúde com pronto atendimento e áreas para prática de esportes.

Para este indicador, a ferramenta do LabCidade estabelecia como parâmetro de análise apenas o tempo de deslocamento de 1 hora por meio do transporte público (LABCIDADE e ITDP, 2014). Procuramos adaptar este parâmetro, transformando-o em um raio cinco quilômetros a partir do perímetro do conjunto, de forma a comparálo com os indicadores anteriores, que resultou na classificação apresentada no Quadro 16.

\section{Quadro 16 - Classificação para o indicador "Usos Esporádicos ou de Abrangência da Cidade"}

\begin{tabular}{ll}
\hline CLASSIFICAÇÃO & PARÂMETRO \\
\hline BOM & Foram encontrados todos os usos no raio de $5 \mathrm{~km}$ a partir do perímetro \\
ACEITÁVEL & Pelo menos um dos usos estava fora do raio de $5 \mathrm{~km}$ a partir do perímetro \\
INSUFICIENTE & Pelo menos um dos usos estabelecidos não é ofertado \\
\hline
\end{tabular}

Fonte: elaboração do autor

$\mathrm{Na}$ análise do indicador para a intervenção Maravilha (Mapa 40), foram encontrados pelo menos um equipamento para cada tipo estabelecido como de uso esporádico ou de abrangência da cidade, o que lhe confere a classificação "Bom". Através do Mapa 41, podemos observar que o uso Instituição Pública de Ensino Superior não foi encontrado dentro do raio de abrangência estabelecido de cinco quilômetros. Deste modo, classificamos o conjunto Maria Tomásia como "Insuficiente" para este indicador.

Comparando os dois mapas, podemos observar uma maior quantidade de equipamentos presentes no raio de $5 \mathrm{~km}$ a partir da área da Maravilha (Mapa 40), em relação a área do Maria Tomásia (Mapa 41). 
Mapa 40 - Usos esporádicos ou de abrangência da cidade na Maravilha

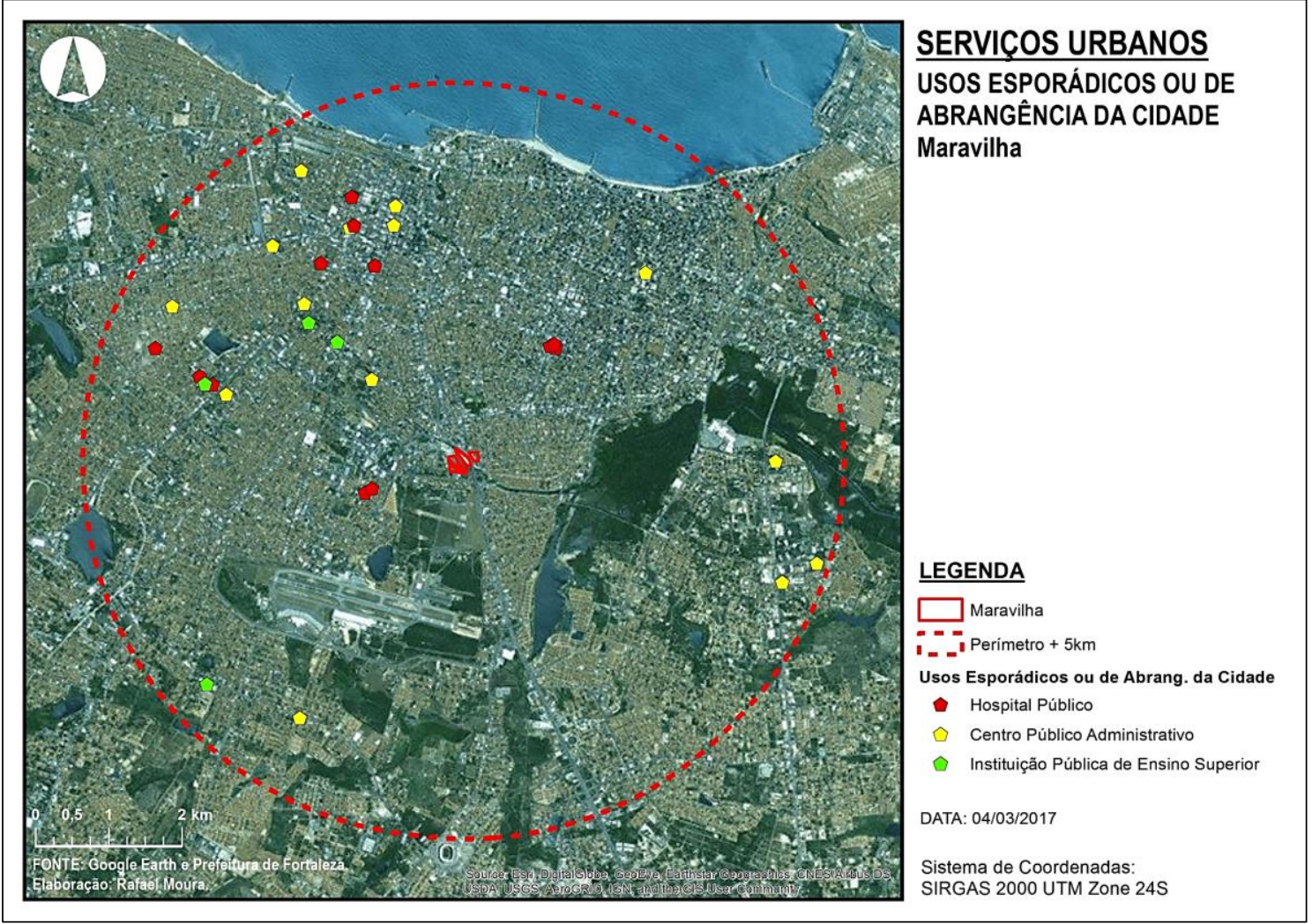

Fonte: Google Earth, HABITAFOR, elaboração do autor

Mapa 41 - Usos esporádicos ou de abrangência da cidade no Maria Tomásia

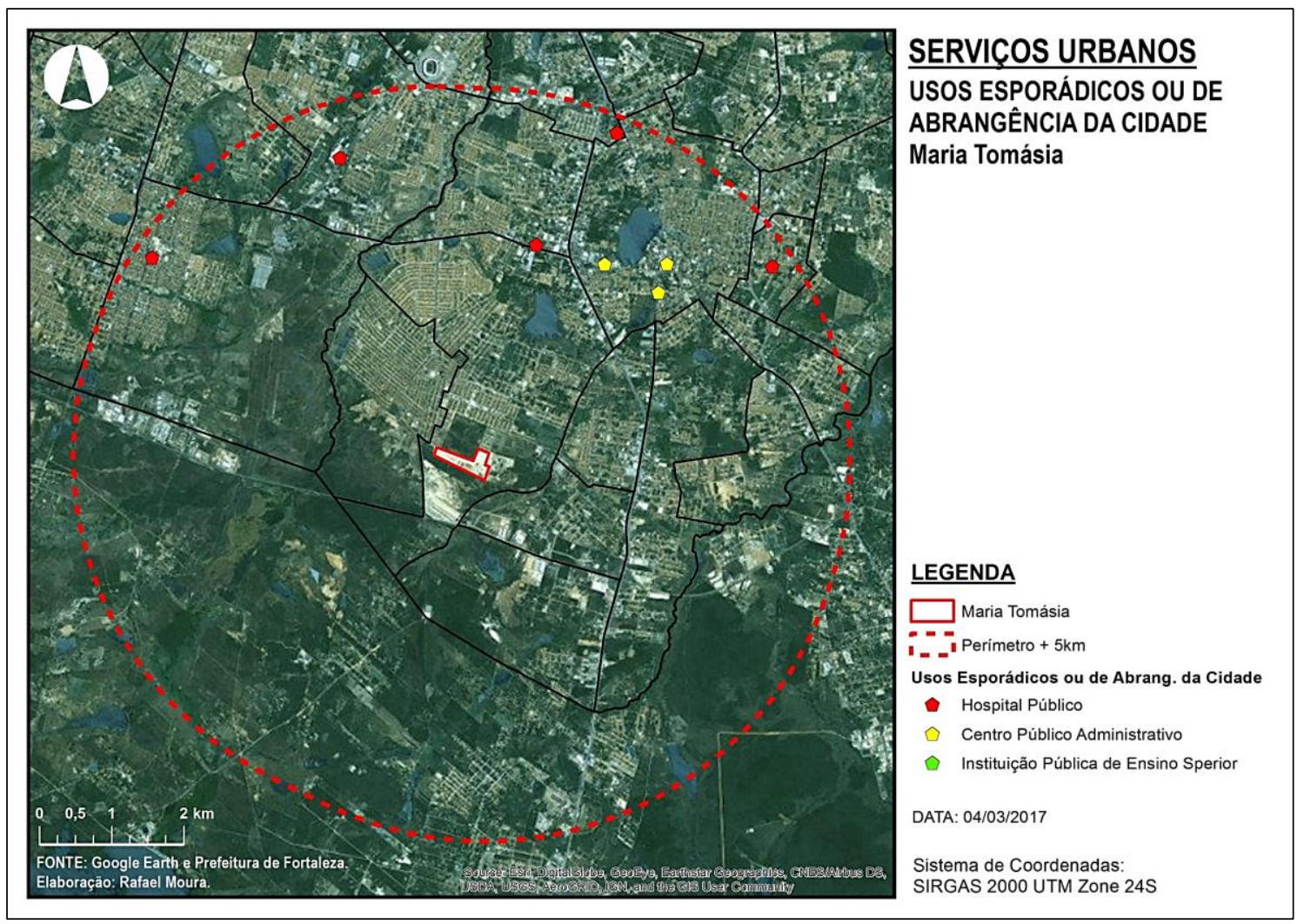

Fonte: Google Earth, HABITAFOR, elaboração do autor 


\subsubsection{Fluidez Urbana}

A forma como um conjunto habitacional é inserido na cidade pode articular ou isolar espaços. A fluidez, em um empreendimento habitacional, é alcançada por meio de uma boa adequação à malha urbana, evitando-se a utilização de elementos de ruptura física e visual da paisagem e de isolamento do conjunto, como muros e grades, que, na realidade, aumentam à vulnerabilidade à violênca (FERREIRA, 2012). Assim, com esta variável, procuramos abordar o desenho e a integração da intervenção na Maravilha e do conjunto Maria Tomásia com o entorno.

A análise aqui apresentada baseou-se na ferramenta de avaliação de inserção urbana desenvolvida pelo LabCidade (LABCIDADE e ITDP, 2014), bem como na abordagem de Ferreira (2012). Estabelecemos dois indicadores para a análise das intervenções, a "Relação com o Entorno" e o "Tamanho das Quadras".

\subsection{5.a. Relação com o Entorno}

O indicador "Relação com o Entorno" tem como objetivo avaliar a relação dos conjuntos com o entorno imediato (LABCIDADE e ITDP, 2014). Buscamos verificar se este abriga edificações e espaços que estimulem a circulação de pessoas ao longo do dia e não promovam o isolamento dos moradores.

Como parâmetro de análise, adotamos o percentual do perímetro do conjunto contíguo a um entorno efetivamente urbano, ou seja, que não abrigue edificações ou equipamentos que constituam barreiras ao deslocamento do pedestre, como rodovias, vias férreas, grandes desníveis topográficos, grandes glebas vazias. Através do software Google Earth, medimos os perímetros das quadras nas intervenções, assim como as extensões que consideradas urbanizadas, e calculamos os somatórios e os percentuais, classificando-os de acordo com o Quadro 17.

Quadro 17 - Classificação do indicador Relação com o Entorno

\begin{tabular}{ll}
\hline CLASSIFICAÇÃO & \% do Perímetro em contato com entorno urbano \\
\hline BOM & Igual a $100 \%$ \\
ACEITÁVEL & Igual a $40 \%$ ou mais \\
INSUFICIENTE & Menos de $40 \%$ \\
\hline
\end{tabular}

Fonte: Elaboração do autor 
Tanto na Maravilha, quanto no Maria Tomásia, o resultado da análise foi classificado como "Insuficente". No primeiro caso, em razão das barreiras à fluidez, rodovia, canal e ferrovia, além da existência de quadras vizinhas com grandes de muro sem comunicação. Para o segundo, há poucos trechos do entorno imediato ao perímetro do conjunto que possa ser considerado efetivamente urbano, dado o isolamento da área onde foi implantado.

Contudo, a perspectiva para o Maria Tomásia é ser cercado por outros conjuntos habitacionais, já em implantação através do PMCMV, o que pode resultar em melhora da relação com o entorno. Já na Maravilha, a perspectiva é de piora, com a implantação e funcionamento do VLT, que dificultará o deslocamento entre os Setores I e II.

Tabela 10 - Resultado da análise para o indicador "Relação com o Entorno"

\begin{tabular}{lllll}
\hline Intervenção & $\begin{array}{l}\text { Somatório dos } \\
\text { Perímetros }(\mathbf{m})\end{array}$ & $\begin{array}{l}\text { Perímetro } \\
\text { Urbanizado }(\mathbf{m})\end{array}$ & Percentual & CLASSIFICAÇÃo \\
\hline Maravilha & $2.314,60$ & 500,10 & $21,61 \%$ & INSUFICIENTE \\
Maria Tomásia & $2.154,00$ & 241,00 & $11,19 \%$ & INSUFICIENTE \\
\hline
\end{tabular}

Fonte: elaboração do autor

\subsection{5.b. Tamanho das Quadras}

Sabemos que quadras grandes ou confinadas podem atuar como barreiras para a circulação de pedestres e dificultando a articulação do conjunto com o bairro e a cidade. Por isso o indicador "Tamanho das Quadras" tem como objetivo avaliar se o desenho urbano das quadras nos estudos de caso proporciona caminhos de pedestre variados, curtos e diretos (LABCIDADE e ITDP, 2014).

Foi estabelecido como parâmetro de análise o perímetro médio das quadras, critério baseado na ferramenta de avaliação de inserção urbana desenvolvida pelo LabCidade (LABCIDADE e ITDP, 2014). Aproveitamos o somatório dos perímetros das quadras, realizado no indicador anterior, e dividimos o valor pelo número de quadras de cada intervenção, classificando o resultado de acordo com o Quadro 18. 
Quadro 18 - Classificação para o indicador Tamanho das Quadras

\begin{tabular}{ll}
\hline CLASSIFICAÇÃO & Perímetro Médio \\
\hline BOM & Até 500 metros \\
ACEITÁVEL & Entre 500 e 800 metros \\
INSUFICIENTE & Mais de 800 metros \\
\hline
\end{tabular}

Fonte: elaboração do autor

Tanto para a Maravilha, quanto para o Maria Tomásia, a classificação obtida para a análise do indicador "Tamanho das Quadras" foi “Bom" (Tabela 11), com o perímetro médio bem abaixo dos 500 metros recomendado pela ferramenta do LabCidade (LABCIDADE e ITDP, 2014). Contudo, comparando as duas intervenções, como na Maravilha as edificações não são muradas, é possível atravessar a quadra praticamente pelo meio, o que já não é viável no Maria Tomásia, pois as casas contíguas umas às outras não permitem essa passagem.

Tabela 11 - Resultado da análise para o indicador "Tamanho das Quadras"

\begin{tabular}{lllll}
\hline Intervenção & $\begin{array}{l}\text { Somatório dos } \\
\text { Perímetros }(\mathbf{m})\end{array}$ & Total de Quadras & Perímetro Médio $(\mathbf{m})$ & CLASSIFICAÇÃo \\
\hline Maravilha & $2.314,60$ & 6 & 385,77 & BOM \\
Maria Tomásia & $9.503,68$ & 32 & 296,99 & BOM \\
\hline
\end{tabular}

Fonte: elaboração do autor

\subsubsection{Uma síntese da análise de inserção urbana}

A crítica aos grandes conjuntos periféricos não é nova, apesar de ter voltado à cena recentemente com as análises sobre a produção habitacional promovida pelo PMCMV. Mesmo com a grande quantidade de estudos sobre os impactos da implantação desses grandes conjuntos em regiões periféricas das cidades, a análise de inserção urbana realizada neste trabalho procurou demonstrar, de uma forma perceptível, o quanto as características desse tipo de produto habitacional pode afetar o cotidiano de seus moradores, resultando numa piora da qualidade de vida.

Com a variável "Localização", demonstramos que a mudança das famílias da Lagoa da Zeza e Vila Cazumba para o Maria Tomásia acarretou um distanciamento das centralidades de Fortaleza, ou seja, um afastamento das áreas onde se concentram as oportunidades de emprego e a oferta de equipamentos e serviços. 
Por sua vez, a variável "Mobilidade" torna evidente a diferença de opções de deslocamento via transporte público entre a Maravilha, localizada em uma área central, e o Maria Tomásia, na periferia sul de Fortaleza. A desigualdade na oferta de linhas de ônibus, itinerários e período de atendimento entre as duas intervenções é extrema, contribuindo para o isolamento dos moradores do Maria Tomásia. Não é à toa, este era o conjunto da HABITAFOR com maior número de venda de casas pelos moradores (BORGES, 2012).

A variável "Infraestrutura" não apresentou grandes diferenças entre a Maravilha e o Maria Tomásia, e nem deveria, já que, em teoria, as intervenções implementadas pelo poder público deveriam ser dotadas de toda a infraestrutura básica. Contudo, podemos perceber diferenças entre os conjuntos e as áreas vizinhas. O entorno da Maravilha aparenta ser melhor servido de infraestrutura do que o do Maria Tomásia. Falamos "aparenta" porque as informações do IBGE que utilizamos na análise não nos permitem verificar a qualidade dos serviços, assim como já mencionamos em relação à coleta de lixo, a ocorrência de episódios de falta de água, por exemplo, pode ser mais frequente em uma das duas intervenções, podendo constituir objeto para futuras investigações.

Com a variável "Serviços Urbanos", observamos que a situação do Maria Tomásia é mais prejudicada, em relação à Maravilha, quanto à oferta de equipamentos de "Uso esporádico ou de abrangência da cidade", como Universidades e Hospitais. Uma investigação mais detalhada, que inclua outros tipos de atividades, que a ferramenta do LabCidade considerou como complementares (por exemplo, bancos, lotéricas, correios, etc.), em oposição àquelas que obrigatoriamente deveriam constar nos limites estabelecidos (LABCIDADE e ITDP, 2014), para os três tipos de usos considerados, pode apresentar uma piora na análise do Maria Tomásia.

Por fim, na variável "Fluidez Urbana", vimos que a situação peculiar da área onde se insere a Maravilha, cortada por uma rodovia, por um canal e por uma linha férrea, pode representar um obstáculo no acesso aos equipamentos e serviços ofertados na área. Por sua vez, a situação de isolamento do Maria Tomásia tem se transformado, justamente devido à produção habitacional promovida pelo PMCMV, o que pode tanto levar a uma melhoria desta condição, mas também pode trazer uma demanda de usuários que os equipamentos existentes na área não serão capazes de atender. 
Habitação social em Fortaleza-CE pós Ministério das Cidades / Considerações Finais - Página | 161

CONSIDERAÇÕES FINAIS 
De nossa experiência profissional, surgiu a necessidade de refletir sobre a produção habitacional promovida pela HABITAFOR e a decisão de tornar a política habitacional em Fortaleza o tema deste trabalho. A partir de então, decidimos o recorte espacial, a cidade de Fortaleza, e temporal, o período a partir da criação do Ministério das Cidades, da pesquisa.

A complexidade que envolve a questão habitacional no Brasil tornou necessária uma abordagem multiescalar, considerando as diferentes esferas de governo e os diversos agentes que participam da política habitacional, com predomínio do foco sobre o governo municipal de Fortaleza.

Ao longo do trabalho, buscamos ter sempre em mente nosso objetivo geral de analisar os impactos da atuação do Ministério das Cidades na política municipal de habitação de interesse social em Fortaleza, visando identificar o reflexo das diretrizes estabelecidas pelo ministério no padrão das intervenções realizadas pelo município.

Assim, o resgate do processo histórico que levou a HABITAFOR a se tornar o principal órgão condutor da política habitacional do município de Fortaleza, elaborado no primeiro capítulo, permitiu-nos identificar alguns pontos importantes a serem realçados, como a manutenção de práticas clientelistas na definição das áreas a serem trabalhadas pela HABITAFOR, através de negociações entre os gestores do órgão e movimentos sociais a eles ligados. O Orçamento Participativo, na realidade, funcionou como um verniz de participação popular, atribuindo um caráter participativo à política habitacional implementada. De fato, a população não tomou parte em decisões fundamentais, como a definição do local de reassentamento das intervenções.

Como reflexo das diretrizes concebidas pelo Ministério das Cidades sobre as intervenções habitacionais promovidas pela Prefeitura de Fortaleza, foi possível constatar o foco da atuação nas áreas de risco e na população com renda entre zero e três salários mínimos, o que já se distingue de políticas habitacionais implementadas anteriormente.

Sobre a localização das intervenções, quando comparamos os mapas de localização dos mutirões (Mapa 6), dos conjuntos executados pela prefeitura através do programa Pró-Moradia (Mapa 9) e as intervenções implementadas após a criação do Ministério 
das Cidades (Mapa 15), não podemos dizer que houve de fato uma melhoria no sentido de aproximar os conjuntos das áreas centrais, apesar de haver intervenções em boas localizações, como a Maravilha, a Lagoa do Opaia e a Lagoa do Papicu. Contudo, percebemos uma tendência de aproximação entre as áreas de origem e as de reassentamento, com algumas exceções, como o conjunto Rosa Luxemburgo, PREUBIS - Cocó e Maria Tomásia, estas duas são bastante significativas pelo número de unidades habitacionais que abrangem, 816 e 1126, respectivamente.

Outro reflexo das diretrizes do Ministério das Cidades constatado nas intervenções, foi a introdução do tema da acessibilidade universal nos programas habitacionais, que pode contribuir para a qualificação das intervenções no que se refere ao desenho urbano. Ainda há um longo caminho para a incorporação do desenho universal nos projetos de HIS, que implica aumento no custo das obras, portanto ainda gera certa objeção dos gestores a sua implementação. No caso das intervenções da HABITAFOR, procurava-se adaptar as unidades de acordo com a demanda levantada pela equipe social, sendo que apenas os banheiros recebiam adaptações, assim como algumas calçadas para criar um caminho acessível para as unidades adaptadas.

A análise do padrão de inserção urbana das intervenções Maravilha e Maria Tomásia, considerando as variáveis localização, mobilidade, infraestrutura, serviços urbanos e fluidez urbana, permitiu a confirmação das vantagens que uma boa localização das intervenções de HIS pode proporcionar às famílias, principalmente no que se refere à questão da mobilidade urbana. Contudo, no caso da Maravilha, as peculiaridades de sua localização, cortada pela BR-116, pelo canal do riacho Taupe e pelo ramal ferroviário, atualmente em conversão para VLT, podem prejudicar o acesso a equipamentos urbanos e a fluidez urbana, entendida como uma boa adequação ao tecido urbano, evitando ou minimizando rupturas.

Apesar de não ter sido definido como objeto desta pesquisa, não pudemos deixar de mencionar o programa Minha Casa Minha Vida. O foco, traduzido em recursos, que o programa passou a receber do governo federal, e demais esferas de governo, resultou no atropelamento da estrutura concebida nos momentos iniciais do Ministério das Cidades e que ainda estava em processo de consolidação. 
Uma consequência constatada em Fortaleza foi o abandono das obras de urbanização de favelas e de melhorias habitacionais, eixos da política habitacional e a conversão dos reassentamentos de algumas intervenções, que já possuíam recursos captado junto ao MCidades, em projetos do PMCMV. Vale dizer que ainda hoje continuam sem ser implementados. Outra consequência foi a desestruturação da equipe técnica da HABITAFOR, pois no PMCMV os projetos são elaborados pelas construtoras, então o órgão público passou a necessitar apenas de uma reduzida equipe técnica, apenas para acompanhar os processos.

Por fim, considerando a situação política e econômica em que se encontra o Brasil, não podemos encerrar este trabalho sem levantar um questionamento: com o retorno do paradigma neoliberal a governar o país e a restrição dos recursos para programas sociais, qual o futuro da política habitacional?

Observamos algumas pistas, através de medidas recentes do governo "Tenebroso", que liberou o saque do saldo do FGTS pelos trabalhadores e alterou os limites de renda atendidos pelo PMCMV com o uso deste fundo. Analisando essas medidas, Rolnik (2017) aponta que, aliadas à paralisação da produção das unidades para a faixa 1 do PMCMV, outra medida do presidente em exercício, essas alterações fazem com que a política pública volte a privilegiar as famílias de classe média, "sem que $o$ Estado tenha qualquer fonte de financiamento para viabilizar uma política habitacional para os mais pobres" (ROLNIK, 2017). 
Habitação social em Fortaleza-CE pós Ministério das Cidades / Referências - Página | 165

REFERÊNCIAS BIBLIOGRÁFICAS 
ABREU NETO, F. A coexistência de direitos no contexto da informailidade urbana: o caso de Fortaleza. Dissertação (mestrado) - Universidade Federal de Pernambuco, Programa de Pós-Graduação em Desenvolvimento Urbano. Recife, 2008.

ACCIOLY, V. M. Estruturação Urbana e Mobilidade na Região Metropolitana de Fortaleza. In: PEQUENO, R.; (ORG.) Como Anda Fortaleza. Rio de Janeiro: Letra Capital: Observatório das Metrópoles, 2009. p. 131-149. ISBN 978-85-7785-044-0.

ALBERNAZ, M. P.; LIMA, C. M. Dicionário ilustrado de arquitettura. São Paulo: ProEditores, v. I - A a I, 1997-1998.

ALMEIDA, A. Entrevista concedida ao autor. Fortaleza, 14 de outubro de 2016.

ALMEIDA, R. C. D. A modernidade e as favelas: a produção do espaço urbano de Fortaleza a partir da seca de 1932. Dissertação (mestrado) - Universidade Estadual do Ceará, Centro de Humanidades, Curso de Mestrado Acadêmico em História. Fortaleza, 2013.

AMORE, C. S. "Minha Casa Minha Vida" para iniciantes (Capítulo 1). In: AMORE, C. S., et al. Minha casa. e a cidade? Avaliação do programa Minha Casa Minha Vida em seis estados brasileiros. 1‥ ed. Rio de Janeiro: Letra Capital, 2015. p. 11-27. ISBN 9788577853779.

AMORE, C. S.; SHIMBO, L. Z.; RUFINO, M. B. C. Minha casa. e a cidade? Avaliação do programa Minha Casa Minha Vida em seis estados brasileiros. Rio de Janeiro: Letra Capital, 2015. ISBN 9788577853779.

AQUINO, E.; PAIVA, E.; BRAGA, S. Entrevista concedida ao autor. Fortaleza, 06 de outubro de 2016.

ARAGÃO, T. A. Influência das políticas habitacionais na construção do espaço metropolitano de Fortaleza: história e perspectivas. Dissertação (mestrado) Instituto de Pesquisa e Planejamento Urbano e Regional, Universidade Federal do Rio de Janeiro. Rio de Janeiro, 2010.

ARAUJO, V. F. Da favela ao conjunto habitacional: mudança de vida, permanência do estigma? Dissertação (mestrado) - Universidade Federal do Ceará, Centro de Humanidades, Departamento de Ciências Sociais, Programa de PósGraduação em Sociologia. Fortaleza, 2013.

ARRETCHE, M. A descentralização como condição de governabilidade: solução ou miragem? Espaço e Debates, v. 16, n. 39, p. 75-86, 1996.

AZEVEDO, S. Desafios da Habitação Popular no Brasil: políticas recentes e tendências. In: CARDOSO , A. L. Habitação social nas metrópoles brasileiras: uma avaliação das políticas habitacionais em Belém, Belo Horizonte, Porto Alegre, Recife, Rio de Janeiro e São Paulo no final do século XX. Porto Alegre: ANTAC, 2007. Cap. 1, p. 12-41. ISBN 978-85-89478-19-9. 
BERNAL, M. C. C. A Metrópole Emergente: a ação do capital imobiliário na estruturação urbana de Fortaleza. Fortaleza: UFC/Banco do Nordeste do Brasil S.A., 2004. ISBN 85-7282-151-1.

BISIO, L. Entrevista concedida ao autor. Fortaleza, 29 de novembro de 2016.

BONDUKI, N. Origens da habitação social no Brasil: arquitetura moderna, lei do inquilinato e difusão da casa própria. 4. ed. São Paulo: Estação Liberdade, 2004. ISBN 85-85865-91-1.

BONDUKI, N. Política de vivienda e inclusión social en Brasil: revisión histórica y nuevas perspectivas en el gobierno de Lula. In: ESPINOSA, J. F. E. Inter/secciones urbanas: origen y contexto en América Latina. Quito: FLACSO, 2009. p. 95-136. ISBN 978-9978-67-202-0.

BONDUKI, N.; ROSSETTO, R. Política e Sistema Nacional de Habitação de Interesse Social. In: MINISTÉRIO DAS CIDADES Curso à Distância de Ações Integradas de Urbanização de Assentamentos Precários, Disciplina 2, Módulo 1. Brasília: Aliança de Cidades, 2008.

BORGES, A. S. C. Dos labirintos da Maravilha ao sonho da casa própria: uma análise de "táticas" e "estratégias" na política de Habitação de Interesse Social em Fortaleza. Dissertação (Mestrado) - Universidade Estadual do Ceará, Centro de Estudos Sociais Aplicados, Curso de mestrado acadêmico em Políticas Públicas e Sociedade. Fortaleza. 2012.

BRAGA, E. M. F. Os labirintos da habitação popular (conjunturas, programas e atores). Fortaleza: Fundação Demócrito Rocha, 1995.

BRASIL. Decreto-Lei no 2.291. Extingue o Banco Nacional da Habitação BNH, e dá outras Providências. 1986.

Orientação Operacional UCP/HBB no 01, de 05 de maio de 2000. Secretaria de Desenvolvimento Urbano do Gabinete da Presidência da República. Brasília, 2000a.

. Orientação Operacional UCP/HBB n 02, de 05 de maio de 2000. Secretaria de Desenvolvimento Urbano do Gabinete da Presidência da República. Brasília, 2000b.

Orientação Operacional UCP/HBB no 03, de 20 de junho de 2000. Secretaria de Desenvolvimento Urbano da Presidência da República. Brasília, 2000c.

. Lei no 10.683, de 28 de maio de 2003. Dispõe sobre a organização da Presidência da República e dos Ministérios, e dá outras providências. Brasília, 2003.

Decreto no 5.031, de 2 de abril de 2004. Dispõe sobre a composição, estruturação, competências e funcionamento do Conselho das Cidades, e dá outras providências. Brasília, 2004a.

. Cadernos MCidades - Política Nacional de Desenvolvimento Urbano. Brasília: Ministério das Cidades, v. 1, 2004b. 
. Cadernos MCidades - Política Nacional de Habitação. Brasília: Ministério das Cidades, v. 4, 2004c.

. Lei no 11.124, de 16 de junho de 2005. Dispõe sobre o Sistema Nacional de Habitação de Interesse Social - SNHIS, cria o Fundo Nacional de Habitação de Interesse Social - FNHIS e institui o Conselho Gestor do FNHIS. Brasília, 2005.

Guia Básico dos Programas Habitacionais. Ministério das Cidades, Secretaria Nacional de Habitação. Brasília, 2007a.

Instrução Normativa no 16, de 4 de Maio de 2007. Regulamenta 0 Programa de Atendimento Habitacional através do Poder Público - PRÓ-MORADIA. Ministério das Cidades. Brasília, 2007b.

Fundo Nacional de Habitação de Interesse Social; Manual para Apresentação de Propostas; Programa: Habitação de Interesse Social; Ação: Apoio à Construção Habitacional para Famílias de Baixa Renda. Ministério das Cldades, Secretaria Nacional de Habitação. Brasília, 2007c.

Fundo Nacional de Habitação de Interesse Social; Manual para Apresentação de Propostas; Programa: Habitação de Interesse Social; Ação: Apoio à elaboração de Planos Habitacionais de Interesse Social. Ministério das Cidades, Secretaria Nacional de Habitação. Brasília, 2007d.

Fundo Nacional de Habitação de Interesse Social; Manual para Apresentação de Propostas; Programa: Urbanização, Regularização e Integração de Assetamentos Precários; Ação: Apoio à Melhoria das Condições de Habitabilidade de Assentamentos Precários. Ministério das Cidades, Secretaria Nacional de Habitação. Brasília, 2007e.

Programa de Aceleração do Crescimento (PAC); Manual de Instruções, período 2007-2010; Projetos Prioritários de Investimentos (PPI); Intervenções em Favelas. Ministério das Cidades, Secretaria Nacional de Habitação, Secretaria Nacional de Saneamento Ambiental. Brasília, 2007f.

Plano Nacional de Habitação. Brasília: Mlnistério das Cidades, Secretaria Nacional de Habitação, 2009. ISBN 978-85-7958-002-4.

Programa Moradia Digna; Manual de Instruções; PPA: 2012-2015; Ações: Apoio à melhoria das condições de habitabilidade de assentamentos precários (FNHIS) e Apoio à urbanização de assentamentos precários (OGU). Ministério das Cidades, Secretaria Nacional de Habitação. Brasília, 2012a.

Programa Moradia Digna; Manual de Instruções; PPA: 2012-2015; Ações: Apoio à provisão habitacional de interesse social (FNHIS). Ministério das Cidades, Secretaria Nacional de Habitação. Brasília, 2012b.

Manual do Programa Habitar Brasil / BID - Orientações do Subprograma de Urbanização de Assentamentos Subnormais. Brasília: Ministério das Cidades, $\mathrm{s} / \mathrm{d}$. 
Manual do Programa Habitar Brasil/BID. Brasília: Ministério das Cidades, s/d.

CABANNES, Y. Mutirão 50: relato de uma experiência pioneira. In: BONDUKI, N. G. Habitat: as práticas bem-sucedidas em habitação, meio ambiente e gestão urbana nas cidades brasileiras. São Paulo: Studio Nobel, 1996. p. 233-237.

CAF. CAF concede recursos para o desenvolvimento urbano integral e turístico do município de Fortaleza, Brasil. CAF - Banco de Desenvolvimento da América Latina, 2013. Disponivel em: <https://www.caf.com/pt/presente/noticias/2013/12/cafconcede-recursos-para-o-desenvolvimento-urbano-integral-e-turistico-do-municipiode-fortaleza-brasil/>. Acesso em: 02 jan. 2017.

CARDOSO, A. L. Política habitacional: a descentralização perversa. Cadernos IPPUR/UFRJ/Instituto de Pesquisa e Planejamento Urbano e Regional da Universidade Federal do Rio de Janeiro, Rio de Janeiro: IPPUR/UFRJ , v. XV, n. 2, p. 105-122, ago-dez 2001. ISSN 0103-1988.

CARNEIRO, A. Entrevista concedida ao autor. Fortaleza, 21 de novembro de 2016.

CARNEIRO, S. B. D. M. Estudo sobre as condições de sustentabilidae urbana nos espaços comuns em conjuntos habitacionais de interesse social em Fortaleza-CE. Dissertação (mestrado) - Universidade Federal do Ceará, Centro de Tecnologia, Programa de Pós-Graduação em Engenharia Civil: Estruturas e Construção Civil. Fortaleza, 2013.

CEARÁ. Lei no 11.732, de 14 de setembro de 1990. Dispõe sobre a incorporação da Fundação Programa de Assistência às Favelas da Região Metropolitana de Fortaleza PROAFA à Fundação dos Serviços Sociais do Estado do Ceará - FUNSESCE e dá outras providências. Fortaleza, 1990.

Lei no 12.961, de 03 de novembro de 1999. Cria a Secretaria da Infraestrutura - SEINFRA, extingue a SETECO e a SDU; reestrutura a STAS, a SEPLAN, a SESA, a SECULT e a SETUR e as entidades que indica; e dá outras providências. Fortaleza, 1999.

CGFNHIS. Resolução no 4, de 10 de novembro de 2006. Aprova as diretrizes das ações programáticas do Fundo Nacional de Habitação de Interesse Social. Conselho Gestor do Fundo Nacional de Habitação de Interesse Social. Brasília, 2006.

Resolução $n^{\circ}$ 9, de 20 de junho de 2007. Aprova as diretrizes e ações para elaboração do Plano Plurianual de Aplicações - PPA, referentes aos recursos do Fundo Nacional de Habitação de Interesse Social, para o período 2008/2011. Conselho Gestor do Fundo Nacional de Habitação de Interesse Social. Brasília, 2007.

DAROS, E. J. Moderação e ordenção do trânsito urbano. São Paulo: Associação Brasileira de Pedestres - ABRASPE, 2007. Disponivel em: <http://www.pedestre.org.br/downloads/MODERACaO\%20E\%20ORDENACaO\%20 DO\%20TRAN SITO\%20URBANO.pdf>. Acesso em: 23 fev. 2017.

DENALDI, R. Plano de Ação Integrada em Assentamentos Precários. Curso à Distância de Ações Integradas de Urbanização de Assentamentos Precários, 
Disciplina 5, Módulo 2. Ministério das Cidades, Secretaria Nacional de Habitação. Brasília, 2008.

DIÁRIO DO NORDESTE. Novas denúncias contra a vereadora Nelba Fortaleza. Jornal Diário do Nordeste, Fortaleza, 23 de dezembro de 2004.

. Famílias do Conjunto Rosa Luxemburgo questionam os valores nas contas de água e luz. Diário do Nordeste, Fortaleza, 15 de maio de 2007. Disponivel em: $<$ http://diariodonordeste.verdesmares.com.br/cadernos/cidade/online/familias-doconjunto-rosa-luxemburgo-questionam-os-valores-nas-contas-de-agua-e-luz1.962308>. Acesso em: 04 de agosto de 2016.

2008.

. Será que terminam em 2008? Diário do Nordeste, Fortaleza, 12 de maio de

Habitafor: fila de 300 metros no último dia. Diário do Nordeste, Fortaleza, 01 de julho de 2009.

DIAS, S. D. D. A. Do espaço concebido à produção do cotidiano em Fortaleza Ceará: a experiência do conjunto habitacional Maria Tomásia, no bairro Jagurussu. Dissertação (Mestrado) - Universidade Estadual do Ceará, Centro de Ciências e Tecnologia, Curso de Mestrado Acadêmico em Geografia. Fortaleza, 2013.

FERREIRA, J. S. W. Produzir casas ou construir cidades? Desafios para um novo Brasil urbano. Parâmetros de qualidade para a implementação de projetos habitacionais e urbanos. São Paulo: LABHAB; FUPAM, 2012. ISBN 978-85-8815005-8.

FORTALEZA. Programa Integrado de Desfavelamento - estudo preliminar. Fundação do Serviço Social de Fortaleza. Fortaleza, 1973.

Lei no 6.541, de 21 de novembro de 1989. Cria o Fundo de Terras no Município de Fortaleza e adota outras providências. Diário Oficial do Município no 9.256. 1989a.

. Lei no 6.543 de 29 de novembro de 1989. Dá nova redação ao artigo 12 da Lei $\mathrm{n}^{0}$ 5.122-A, de 13 de março de 1979 alterado pela Lei $\mathrm{n}-5.161$ de 04 de junho de 1979 e pela Lei $n \div 5.532$, de 18 de dezembro de 1981 e adota outras providências. Diário Oficial do Município no 9.256. 1989b.

Decreto no 8.130, de 29 de novembro de 1989. Institui a Comissão de Implantação de Projetos Habitacionais de Interesse Social e adota outras providências. Diário Oficial do Município de Fortaleza, no 9.256. 1989c.

. Decreto no 8.303, de 21 de maio de 1990. Dá nova estrutura à Comissão de Implantação de Projetos Habitacionais de Interesse Social e Infraestrutura Urbana, e adota outras providências. Diário Oficial do Município de Fortaleza, no 9.380. 1990.

Lei no 6919, de 11 de julho de 1991. Institui o Fundo de Apoio aos Programas de habitaçaõ e ao Projeto PRORENDA e dá outras providências. Diário Oficial do Município de Fortaleza, no 9.657. 1991. 
Lei no 7.061, de 16 de janeiro de 1992. Plano Diretor de Desenvolvimento Urbano. Fortaleza. 1992.

. Lei no 7.966, de 09 de dezembro de 1996. Cria e dispõe sobre a composição, atribuições, organização e funcionamento do Conselho Municipal de Habitação Popular - COMHAP, e dá outras providências. Diário Oficial do Município nº 11.002 . 1996.

. Lei no 8.000, de 29 de janeiro de 1997. Dispõe sobre a organização administrativa da Prefeitura Municipal de Fortaleza, e dá outras providências. Diário Oficial do Município no 11.032. 1997.

Lei no 8.259, de 28 de abril de 1999. Autoriza o Município de Fortaleza a firmar convênio e contratos com o Ministério do Orçamento e Gestão, através da sua SEPURB, e/ou com a SEDU da Presidência da República, com a CEF e com o Estado do Ceará, para o fim que indica e dá outras providências. Diário Oficial do Município no 11.595. 1999a.

Lei $n=8.283$, de 30 de junho de 1999. Cria a Secretaria Municipal de Desenvolvimento Econômico (SMDE), na forma que indica, e dá outras providências. Diário Oficial do Município no 11.628. 1999b.

Decreto no 10.552, de 14 de julho de 1999. Dispõe sobre a finalidade, competências, estrutura organizacional e distribuição de cargos comissionados da Secretaria Municipal de Desenvolvimento Econômico - SMDE. Diário Oficial do Município de Fortaleza, no 11.638. 1999c.

Decreto no 10.661, de 20 de dezembro de 1999. Altera a composição e competência da Comissão de Implantação de Projetos Habitacionais de Interesse Social e Infraestrutura Urbana. Diário Oficial do Município de Fortaleza, ํㅜ 11.749. 1999d.

. Plano Estratégico Municipal Para Assentamentos Subnormais - PEMAS. Instituto Brasileiro de Administração Municipal (IBAM): Comissão de Implantação de Projetos Habitacionais de Interesse Social e Infraestrutura Urbana (COMHAB). Fortaleza. 2001.

. Extrato - Contrato de prestação de serviço. Diário Oficial do Município de Fortaleza, Fortaleza, 22 de julho de 2002.

Política Habitacional de Interesse Social do Município de Fortaleza (PHIS) - Diagnóstico da Situação Habitacional - Etapa II, Volume I. Comissão de Implantação de Projetos Habitacionais de Interesse Social e Infraestrutura Urbana (COMHAB) : Centro de Treinamento e Desenvolvimento (CETREDE). Fortaleza, 2003a.

Lei no 8.810, de 30 de dezembro de 2003. Autoriza a criação da Fundação de Desenvolvimento Habitacional de Fortaleza (HABITAFOR). Diário Oficial do Município nำ12.742. 2003b. 
. Lei no 9.132, de 18 de dezembro de 2006. Institui o Conselho Municipal de Habitação Popular de Fortaleza (COMHAP), dispõe sobre o Fundo Municipal de Habitação (FMH) e dá outras providências. Diário Oficial do Município no 13.478. 2006.

. Lei Orgânica do Município. Fortaleza, 2006.

Projeto de Trabalho Técnico Social (PTTS) - Projeto Integrado de Urbanização das Lagoas da Zeza e Vila Cazumba. Prefeitura de Fortaleza, Fundação de Desenvolvimento Habitacional de Fortaleza (HABITAFOR). Fortaleza, 2006.

Projeto de Trabalho Técnico Social (PTTS) da Lagoa do Papicu Comunidade do Pau Fininho. Prefeitura de Fortaleza - Fundação de Desenvolvimento Habitacional de Fortaleza (HABITAFOR). Fortaleza, 2007.

Projeto Executivo de reassentamento das famílias remanejadas das áreas de intervenção da Lagoa da Zeza e Vila Cazumba. Volume IV, Tomo 1 Memorial Descritivo. Prefeitura de Fortaleza, Fundação de Desenvolvimento Habitacional de Fortaleza (HABITAFOR), ENGESOFT - Engenharia e Consultoria S/C Ltda. Fortaleza, 2007.

Li Complementar no 62, de 02 de fevereiro de 2009. Institui o Plano Diretor Participativo do Município de Fortaleza e dá outras providências. Fortaleza, p. Diário Oficial do Município de Fortaleza, no 14.020. 2009.

Programa de Requalificação Urbana com Inclusão Social (PREURBIS) Projeto de Participação Comunitária da Bacia do Rio Cocó. Prefeitura de Fortaleza - Secretaria Municipal de Desenvolvimento Urbano e Infraestrutura. Fortaleza, 2010.

Plano Local de Habitação de Interesse Social de Fortaleza - PLHISFor, Produto V - Proposta Final (complementada e revisada). Prefeitura de Fortaleza, Fundação de Desenvolvimento Habitacional de Fortaleza - HABITAFOR. Fortaleza, 2013.

Decreto no 13.876, de 29 de agosto de 2016. Nomeia os Conselheiros do Conselho Municipal de Habitação Popular de Fortaleza (COMHAP), eleitos na II Conferência Municipal de Habitação de Fortaleza, e dá outras providências. Diário Oficial do Município de Fortaleza, nº 15.843. 2016.

Plano Fortaleza 2040, Volume 2 - Equidade social, territorial e econômica. Instituto de Planejamento de Fortaleza - IPLANFOR, Prefeitura Municipal de Fortaleza. Fortaleza, 2016.

Plano de Trabalho Técnico Social (PTTS) - São Cristóvão / Campo Estrela. Prefeitura de Fortaleza / Fundação de Desenvolvimento Habitacional de Fortaleza (HABITAFOR). Fortaleza, s/d.

FREITAS, C. S.; PEQUENO, R. Produção habitacional na região metropolitana de Fortaleza: avanços e retrocessos. XIV Encontro Nacional da ANPUR, Rio de Janeiro, p. $\mathrm{s} / \mathrm{n}$, maio 2011 . Disponivel em: <http://www.observatoriodasmetropoles.net/download/renato_pequeno2.pdf>.

Acesso em: 13 de julho de 2013. 
FREITAS, J. A. D. S. A produção social do espaço urbano em Fortaleza: estudo da troca e permuta de unidades habitacionais entre os Conjuntos Habitacionais Maravilha e Maria Tomásia. Dissertação (mestrado) - Universidade Estadual do Ceará, Centro de Estudos Sociais Aplicados, Mestrado Acadêmico em Serviço Social. Fortaleza, 2014.

FUNDAÇÃO JOÃO PINHEIRO. Déficit habitacional municipal no Brasil. Fundação João Pinheiro. Centro de Estatística e Informações. Belo Horizonte, 2013.

GALVÃO, W. J. F.; ORNSTEIN, S. W.; ONO, R. A avaliação pós-ocupação em empreendimentos habitacionais no Brasil: da reabilitação aos novos edifícios. In: VILLA, S. B.; ORNSTEIN, S. W.; (ORG.) Qualidade ambiental na habitação: avaliação pós-ocupação. São Paulo: Oficina de Textos, 2013. Cap. 2. ISBN 978-857975-076-2.

GOIS, R. A. D. A metrópole e os mega-eventos. Implicações socioespaciais da Copa do Mundo de 2014 em Fortaleza. Dissertação (mestrado) - Universidade Federal do Ceará, Centro de Ciências, Departamento de Geografia, Programa de PósGraduação em Geografia. Fortaleza, 2013.

GONDIM, L. M. R. À sombra do BNH: a nova política habitacional em Fortaleza-CE (2005-2011). O público e o privado - Revista do PPG em Sociologia da Universidade Estadual do Ceará (UECE), Fortaleza, n. 21, p. 147-165, Janeiro/Junho 2013. ISSN 2238-5169.

HABITAFOR. 1a. Reunião do Grupo de Trabalho para criação do Território de Habitabilidade no conjunto residencial Maria Tomásia. (Apresentação) Fundação de Desenvolvimento Habitacional de Fortaleza - HABITAFOR. Fortaleza, 2009.

HATSUE, V. Entrevista concedida ao autor. Fortaleza, 08 de outubro de 2016.

IACOVINI, V. Mobilidade urbana, transportes e VLT Parangaba/Mucuripe: histórico, conceitos, conflitos e impactos sócio-espaciais. In: COSTA, M. C. L., et al. Fortaleza; os impactos da copa do mundo de 2014. Fortaleza: Expressão Gráfica e Editora, 2015. Cap. 978-85-420-0628-5, p. 251-295.

JARAMILLO, S. Las formas de producción del espacio construido en Bogotá. In: PRADILLA, E. Ensayos sobre el problema de la vivienda en México. México: Latina UNAM, 1982. p. 149-212.

JUCÁ, G. N. M. Verso e reverso do perfil urbano de Fortaleza. São Paulo: Annablume, 2003. ISBN 85-7419-143-4.

KOWALTOWSKI, D. C. C. K. et al. Métodos e instrumentos de avalição de projetos destinados à habitação de interesse social. In: VILLA, S. B.; ORNSTEIN, S. W.; (ORG.) Qualidade ambiental na habitação: avaliação pós-ocupação. São Paulo: Oficina de Textos, 2013. Cap. 7. ISBN 978-85-7975-076-2.

KOWARICK, L. Escritos Urbanos. São Paulo: Editora 34, 2000. ISBN 85-7326-1633. 
LABCIDADE; ITDP. Ferramenta de avaliação de inserção urbana para os empreendimentos de faixa 1 do programa Minha Casa Minha Vida. Laboratório espaço público e direito à cidade (LabCidade) da Faculdade de Arquitetura e Urbanismo da USP, Instituto de Políticas de Transporte e Desenvolvimento (ITDP Brasil). São Paulo, 2014.

LEHAB. Nota Metodológica: Reconhecimeno dos espaços centrais da Região Metropolitana de Fortaleza. Texto não publicado. Laboratório de Estudos da Habitação (LEHAB), Universidade Federal do Ceará. Fortaleza, 2015.

LEITÃO, K. O. A dimensão territorial do Programa de Aceleração do Crescimento: um estudo a partir do PAC no Estado do Pará e o lugar que ele reserva à Amazônia no desenvolvimento do país. Tese (doutorado) - Faculdade de Arquitetura e Urbanismo, Universidade de São Paulo. São Paulo, 2009.

LIMA, E. D. Há 10 anos, Luizianne Lins era eleita. Blog do Eliomar, 2014. Disponivel em:

$<$ http://blog.opovo.com.br/blogdoeliomar/ha10anosluiziannelinseraeleitaprefeitadefort aleza/>. Acesso em: 14 de dezembro de 2016.

MACHADO, E. G. Planejamento urbano, democracia e participação popular: o caso da revisão do plano diretor de Fortaleza (2003-2008). Tese (Doutorado) Universidade Federal do Ceará, Centro de Humanidades, Programa de PósGraduação em Sociologia. Fortaleza, 2011.

MARICATO, E. Política Urbana e Habitação Social: um assunto pouco importante para o Governo FHC. Revista Praga, São Paulo: HUCITEC, v. 1, n. 6, p. 67-78, 1998. Disponivel

em:

$<$ http://www.ipea.gov.br/portal/index.php?option=com_content\&view=article\&id=5774 \&ltemid=9>. Acesso em: 10 julho de 2013.

MARICATO, E. O Ministério das Cidades e a Política Nacional de Desenvolvimento Urbano. Revista Políticas Sociais - Acompanhamento e Análise, n¹2, IPEA, fev. 2006. p. 211-220. Disponivel em: $<$ http://www.ipea.gov.br/portal/index.php?option=com_content\&view=article\&id=5774 \&ltemid=9 > . Acesso em: 10 de julho de 2013.

MARICATO, E. O impasse da política urbana no Brasil. 3ª . ed. Petrópolis, RJ: Vozes, 2014. ISBN 978-85-326-4147-2.

MARQUES, O. Entrevista concedida ao autor. Fortaleza, 07 de outubro de 2016.

MÁXIMO, F. R. C. C. Moradia, arquitetura e cidade: mudanças e permanências na produção da habitação social no espaço urbano metropolitano de Fortaleza. Dissertação (mestrado) - Instituto de Arquitetura e Urbanismo, Universidade de São Paulo. São Carlos, 2012.

MONTEIRO, E. R. Deslocamentos da forma urbana na zona sudeste de Fortaleza. Dissertação (mestrado) - Programa de Pós-Graduação em Urbanismo - PROURB, Universidade Federal do Rio de Janeiro. Rio de Janeiro, 2007. 
NEVES, F. D. C. A seca na história do Cceará. In: SOUZA, S.; (ORG.) Uma nova história do Ceará. Fortaleza: Demócrito Rocha, 2000. p. 76-102. ISBN 85-86375-837.

O ESTADO CE. Moradores da comunidade Pau Fininho ainda aguardam Conjunto Habitacional. O Estado CE, Fortaleza, 20 out. 2009. Disponivel em: <http://www.oestadoce.com.br/geral/moradoresdacomunidadepaufininhoaindaaguard amconjuntohabitacional>. Acesso em: 06 de fevereiro de 2017.

O POVO. Habitafor. Jornal O POVO, Fortaleza, 24 de novembro de 2003.

. Sem explicação sobre a favela do Gavião. Jornal O POVO, Fortaleza, 11 de fevereiro de 2004a.

fevereiro de 2004b.

Vereadores em choque com SERs. Jornal O POVO, Fortaleza, 14 de

. Nelba é acusada de usar critério político para distribuir moradias. Jornal $\mathbf{O}$ POVO, Fortaleza, 11 de novembro de 2004c.

. Maria Luiza. Há 30 anos, uma onda vermelha tomava conta de Fortaleza. Jornal O POVO, Fortaleza, 15 de novembro de 2015.

. Especialistas e sociedade apresentam novas propostas de modificação à Lei de Uso e Ocupação do Solo (LUOS). Jornal O Povo, Fortaleza, 15 de dezembro de 2016a.

. Coelce vira Enel e foca em geração distribuída. Jornal O Povo, Fortaleza, 08 nov. 2016b. Disponivel em:

<http://www.opovo.com.br/app/opovo/economia/2016/11/08/noticiasjornaleconomia,3 668284/coelce-vira-enel-e-foca-em-geracao-distribuida.shtml>. Acesso em: 29 de janeiro de 2017.

OLIVEIRA, F. D. Crítica à razão dualista: o ornitorrinco. 1. ed. São Paulo: Boitempo, 2013. ISBN 978-85-7559-036-2.

PASTERNAK, S. São Paulo e suas favelas. Revista Pós, São Paulo, n. 19, p. 176197, junho de 2006. ISSN 1518-9554.

PEQUENO, R. Castelo Encantado - estudo de caso de Fortaleza. Relatório final da pesquisa Parâmetros para urbanização de favelas - LABHAB, FAUUSP. São Paulo, p. 12-59. 1999.

PEQUENO, R. Desenvolvimento e degradação no espaço-intraurbano de Fortaleza. Tese (doutorado) - Faculdade de Arquitetura e Urbanismo, Universidade de São Paulo. São Paulo, 2002.

PEQUENO, R. Desenvolvimento e degradação no espaço intraurbano de Fortaleza. X Encontro Nacional da ANPUR. Belo Horizonte, 2003.

PEQUENO, R. Políticas habitacionais, favelização e desigualdades sócio-espaciais nas cidades brasileiras: transformações e tendências. Scripta Nova - Revista 
Electrónica de Geografía y Ciências Sociales, Barcelona, v. XII, n. 270 (35), 01 agosto 2008. ISSN 1138-9788. Disponivel em: <http://www.ub.edu/geocrit/sn/sn270/sn-270-35.htm>. Acesso em: 18 de agosto de 2012.

PEQUENO, R. Um breve panorama histórico das políticas habitacionais em Fortaleza. Entrevista concedida ao arquiteto Rérisson Máximo. Fortaleza, 20 de dezembro de 2011.

PEQUENO, R.; ROSA, S. V. O Programa Minha Casa Minha Vida na Região Metropolitana de Fortaleza-CE: análise dos arranjos institucionais. Cadernos Metrópole, São Paulo: EDUC, v. 18, n. 35, p. 191-215, abr. 2016. ISSN 1517-2422.

REIS, A. T. D. L.; LAY, C. D. O projeto da habitação de interesse social e a sustentabilidade social. Ambiente Construído, Porto Alegre, v. 10, n. 3, p. 99-119, jul./set. 2010. ISSN 1678-8621.

RODRIGUES, A. M. Moradia nas cidades brasileiras. São Paulo: Contexto, 1990.

RODRIGUES, D. Entrevista concedida ao autor. Fortaleza, 24 de novembro de 2016.

ROLNIK, R. Mudanças no FGTS e no Minha Casa Minha Vida: e os mais pobres? Blog da Raquel Rolnik, São Paulo, 27 fev. 2017. Disponivel em: <https://raquelrolnik.wordpress.com/>. Acesso em: 24 de fevereiro de 2017.

ROLNIK, R.; NAKANO, K. As armadilhas do pacote habitacional. Le Monde Diplomatique Brasil, 05 mar. 2009. Disponivel em:

$<$ http://www.diplomatique.org.br/artigo.php?id=461 >. Acesso em: 25 de março de 2009.

ROSA, S. V.; PEQUENO, R.; SILVA, H. A. D. Panorama dos primeiros empreendimentos entregues do Programa MCMV da Faixa 1 na Região Metropolitana de Fortaleza (RMF). 3 o Congresso Internacional Sustentabilidade e Habitação de Interesse Social. Porto Alegre, 2014.

RUFINO, B. C. Incorporação da metrópole: centralização do capital imobiliário e nova produção de espaço em Fortaleza. Tese (Doutorado) - Faculdade de Arquitetura e Urbanismo, Universidade de São Paulo. São Paulo, 2012.

SANTOS, C. H. M. Políticas Federais de Habitação no Brasil: 1964/1998. Texto para discussão no 654. IPEA. Brasília, 1999.

SOUZA, M. A. A. O II PND e a política urbana brasileira: uma contradição evidente. In: DEÁK, C.; SCHIFFER, S. R. 0 processo de urbanização no Brasil. $2^{\underline{a}}$ ed. atualizada, São Paulo: Editora da Universidade de São Paulo, 2010. Cap. 4. ISBN 978-85-314-0513-6.

TRIBUNA DO CEARÁ. Conjunto Maria Tomásia entregue às larvas de mosca e à podridão. Tribuna do Ceará (Portal), Fortaleza, 04 de abril de 2014. Disponivel em: $<$ http://tribunadoceara.uol.com.br/videos/gentenatv/>. Acesso em: 23 de fevereiro de 2017. 
VALENTE, R. C. Acordos, projetos e programas: uma abordagem antropológica das práticas e dos saberes administrativos da GTZ no Brasil. Tese (Doutorado) Programa de Pós-graduação em Antropologia Social, Universidade Federal do Rio de Janeiro. Rio de Janeiro, 2007. 